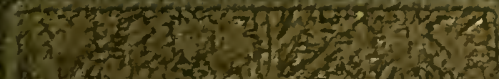

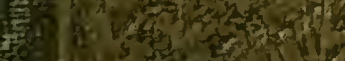

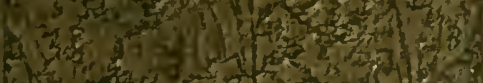
(3)

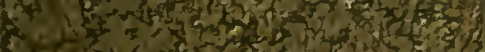

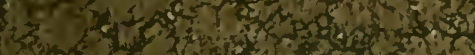
Fी

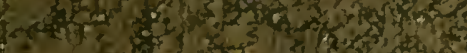

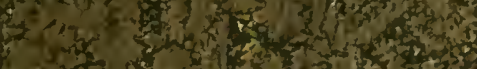

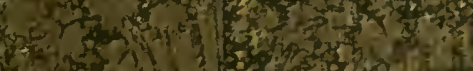

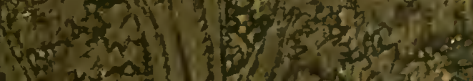

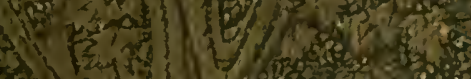
से 3.

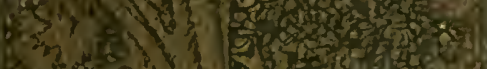

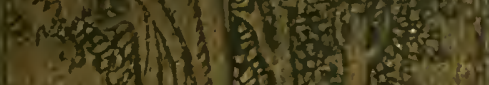

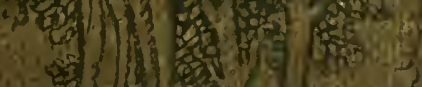
(1)

nia
SALMON<smiles>[123In]</smiles>

TROUT

(2)

DFAN GAE ono obfers

\title{
1
}

(1)

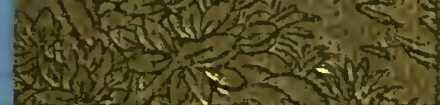

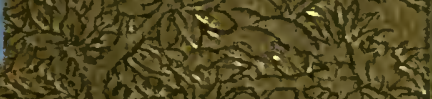

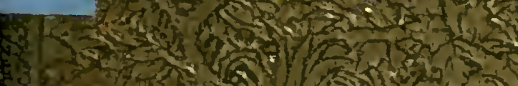
6. 3 (3)

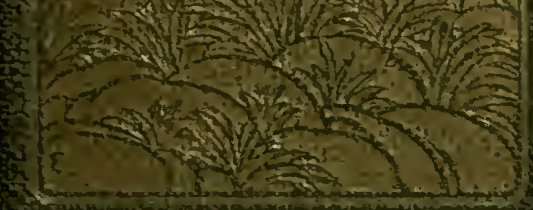

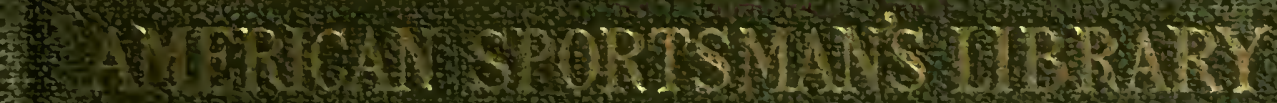

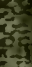

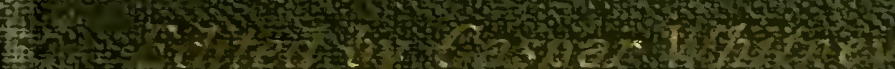

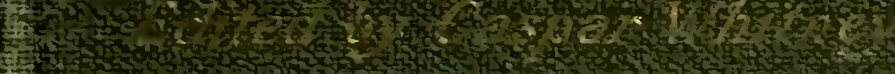




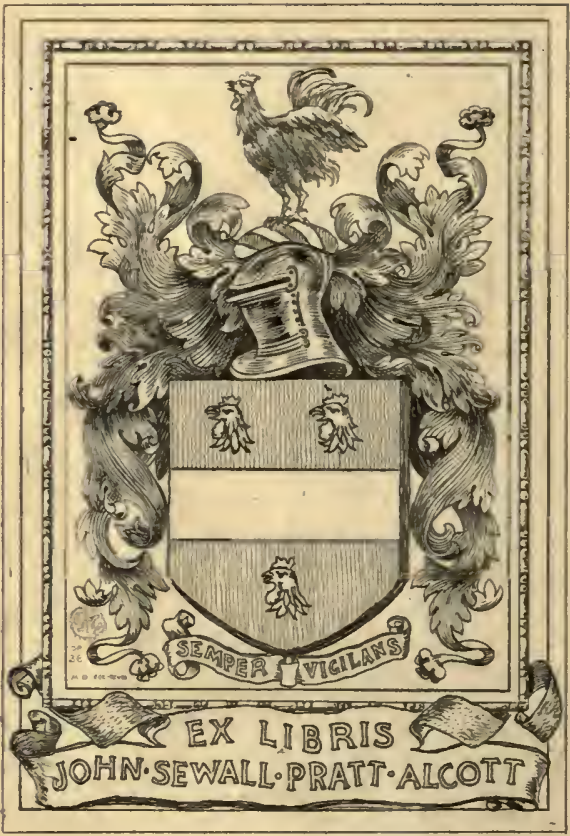




$$
\begin{array}{r}
18 \\
9
\end{array}
$$


Digitized by the Internet Archive in 2007 with funding from Microsoft Corporation 
THE AMERICAN SPORTSMAN'S LIBRARY EDITED BY

CASPAR WHITNEY

\section{SALMON AND TROUT}


The $>$ Xx. 


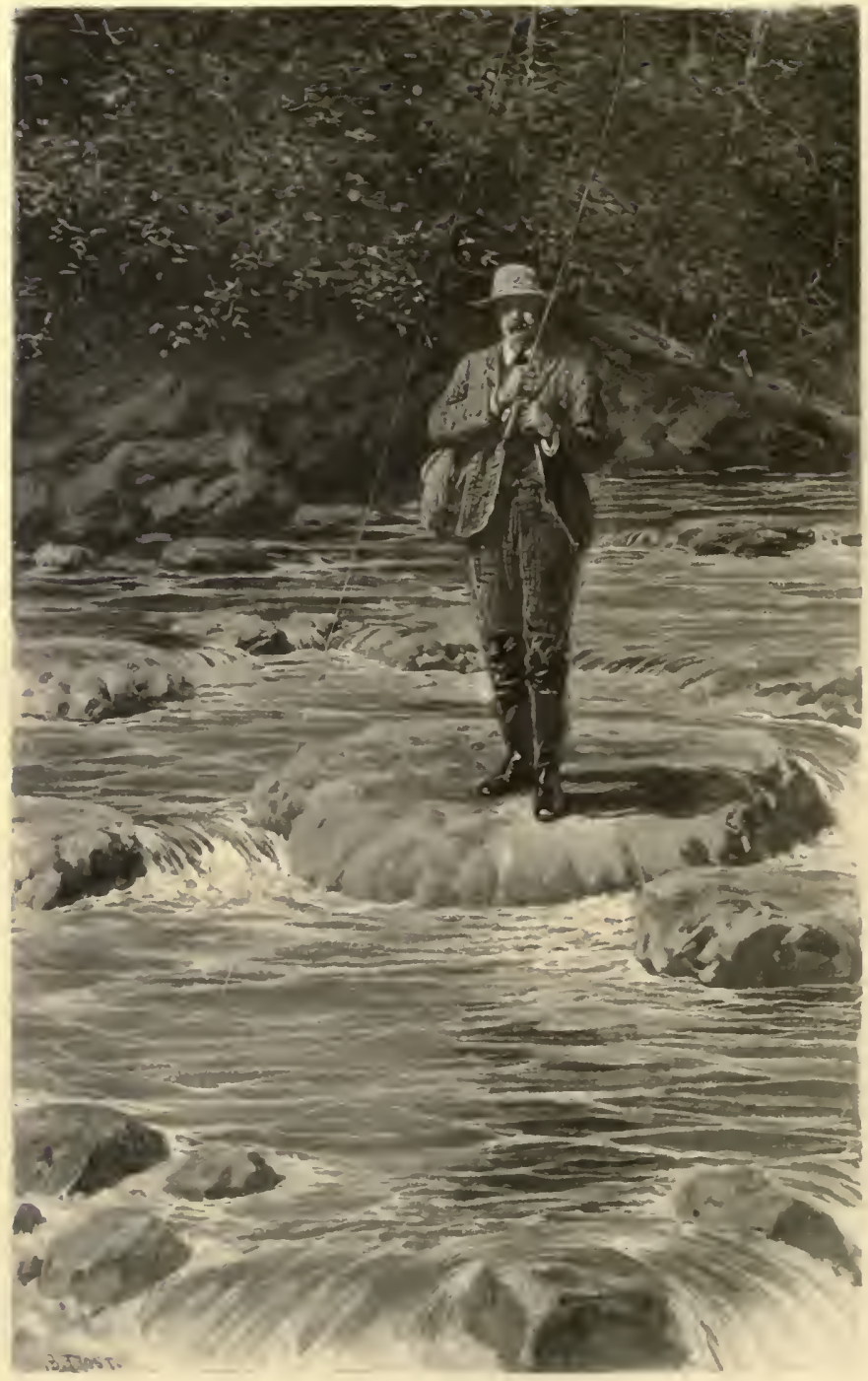




\section{SALMON AND TROUT}

BY

DEAN SAGE, C. H. TOWNSEND, H. M. SMITH

AND WILLIAM C. HARRIS

ILLUSTRATED BY A. B. FROST, TAPPAN ADNEY

MARTIN JUSTICE, AND OTHERS

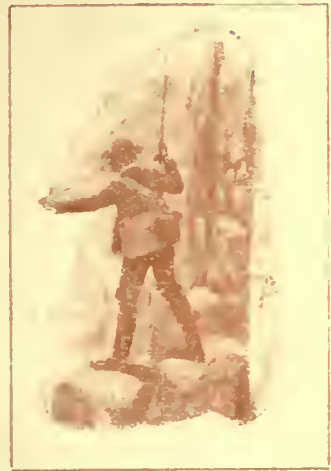

Now

THE MACMILLAN COMPANY

LONDON: MACMILLAN \& CO., LTD.

1902 
Copyright, I902,

BY THE MACMILLAN COMPANY.

Set up and electrotyped June, 1902.

Normood 3ress

J. 8. Cushing \& Co,- Berwick \& Smith

Norwood Mass, U.S.A. 


\section{CONTENTS}

\section{THE ATLANTIC SALMON}

\section{By Dean Sage}

CHAPTER

I. History and Habits . . . . . . . I

II. Where to be Found . . . . . . 37

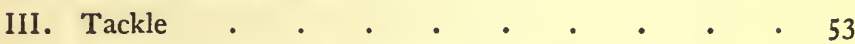

IV. Casting and Working the Fly . . . . . 9I

V. Fishing the Pool . . . . . . . 99

VI. Striking, Playing, and Landing . • • • • II4

VII. Hours for Angling, and Miscellaneous Advice and

Experiences . . . . . . . . I30

\section{THE PACIFIC SALMONS}

By C. H. Townsend and H. M. Smith

The Pacific Salmons

\section{THE TROUTS OF AMERICA}

\section{By William C. Harris}

I. Angling, its Antiquity and Literature-Distribution of Trouts and Charrs - Classification - Native Trouts and Foreign Species introduced to American Waters

II. The Salmon-Trouts - The Cut-throat Series - Popular and Technical Names - Somka or Mykiss Trout of Kamchatka - Columbia River Trout - Rocky 
Mountain or Cut-throat Trout - Yellowstone River Trout - Trout of Idaho and Washington - Rio Grande Trout .

III. Salmon-Trouts Continued - Colorado River Trout Waha Lake Trout - Greenback Trout - Yellow-fin Trout - Lake Tahoe or Truckee Trout - Trout of Lake Webber - Utah Lake Trout - Salmon-Trout of Lake Sutherland - Spotted Trout of Lake Sutherland — Long-Headed Trout of Lake Crescent . . .

IV. Salmon-Trouts Continued - The Steelhead Series Typical Steelhead - Kamloops Trout - Blueback Trout of Lake Crescent, Washington - Speckled Trout of Lake Crescent, Washington . • . 240

V. Salmon-Trouts Continued - The Rainbow Series Rainbow or Coast Range Trout - Brook Trout of Western Oregon - McCloud River (California) Rainbow - Kern River Trout - No-Shee Trout - Golden Trout of Mt. Whitney (California) - Brown or German Trout - Lock Leven Trout . . • . 249

VI. The Charr-Trouts, their Habits, External Markings, and Classification - The Great Lake Trouts and Methods of Capture - The Eastern Brook Trout, Development and Extent of their Sense of Sight, Hearing, Taste, Smell, and Touch . . . . 283

VII. The Charr-Trouts Continued - The Dublin Pond Trout - The Dolly Varden Trout - The Sea Trout, "Salters" - The Saiblings - The Alpine or European Charr or Saibling - The Greenland Charr - The Long-finned Charr - The Floeberg Charr - The Arctic Charr - The Sunapee Trout - The Oquassa Trout - The Lac de Marbre Trout . 


\section{Contents}

VIII. Methods of Fishing for Trout - Fly Fishing and Bait

PAGE Fishing - Up-stream or Down-stream - Atmospheric Conditions - How a Trout Brook is Fished-The Grasshopper Cast - Flies to be Used - Dry and Wet Fly Fishing - Fly Fishing at Night - Flies used in Lake Fishing

IX. Casting the Fly - How it is Done - The Switch or Spey Cast - Handling a Hooked Trout - Bait Fishing - Selecting Fishing Tackle, Rods, Reels, Lines, Leaders, etc.

X. How to tie Artificial Flies $\mathrm{X}$ INDEX 



\section{LIST OF ILLUSTRATIONS}

WELL HoOKed • • • • • • • Frontispiece FACING PAGE

The Atlantic Salmon (Salmo salar) • • • $\quad$ - 23 INDIANS SPEARING SALMON • • • • • •

Toad Brook Pool, Restigouche River • • • 55

Head of Landlock Salmon in Spawning Season • • 75 A Pacific Salmon after Spawning • • • • • 75 Atlantic Salmon during Spawning Season • • • 75 The Upsalquitch Pool • • • • • • • IO3

Drifting down Stream with Flambeaux to see the

SALMON • • • • • • • • • • • • I39

The Humpback Salmon (Male), Alaska • . . I5I indian Salmon Fishing Platforms, Chilkoot Stream, ALASKA • $\quad \cdot \quad \cdot \quad \cdot \quad \cdot \quad \cdot \quad \cdot \quad \cdot \quad \cdot \quad \cdot 163$ A Typical Spawning Riffle $\cdot$ • • • • . 185 The Brook Trout (Salvelinus fontinalis, male) • . 199 His First Trout $\quad \cdot \quad \cdot \quad \cdot \quad \cdot$ • The Oquassa, or Blueback Trout (Salvelimus oquassa) 227 The Sunapee Trout, or Golden Saibling (Salvelinus alpinus aureolus) • • • • • • • • • 227 The German, or Brown Trout (Salmo fario) • • 227 The Crucial Moment • • • • • • • 245 
The Steelhead Trout (Salmo gairdneri) . • • 253

The RaInbow Trout (Salmo irideus) . . . . 253

The Lock Levin Trout (Salmo levinensis) • • • 253

The Dublin Pond Trout (Salvelinus fontinalis agassizii) 263

The Montana Grayling • • • • • • 263

Where the Big Ones Lie . • . . . . . $28 \mathrm{I}$

The Michigan Grayling • • • • • • • 3I5

First Dorsal Fin of Michigan Grayling. Reduced

ONE-HALF. FROM A I $\frac{3}{4}$ LB. FISH • • • • 315

Where Expertness is NeEded • • • • • • 333

The Cut-throat, or Waha Lake Trout (Salmo clarkii

bouvieri). • • • • • • • • • 351

The Great Lake Trout (Cristivomer namaycush) • • $35 \mathrm{I}$

The Dolly Varden Trout (Salvelinus parkei) • • $35 \mathrm{I}$

LANDED • • • • • • • • • • • 371 


\title{
THE ATLANTIC SALMON \\ (Salmo Salar)
}

\author{
By Dean Sage
}





\section{THE ATLANTIC SALMON (Salmo Salar)}

\section{CHAPTER I}

\section{HISTORY AND HABITS}

Concerning no fish except the trout has so much been written as on the salmon, and the result of the whole body of literature on the subject is to give to the Philistine, meaning all who have never caught salmon and many who have done so, numerous erroneous ideas on the subject along with a few "proved facts." This state of things is largely due to the little positive existing knowledge of the salmon, except during his brief journeys to his native or other rivers, and to his many vacillating and inconsistent characteristics while under observation, especially that of a necessarily temporary kind. He will show one day the courage and voracity of a hungry lion, the next the timidity of a hare. At 9 A.m. every fish in a pool may be ruled by tendencies to investigate with boldness and disregard of consequences almost anything from a gnat to a swallow or squirrel in the river. 
At 9.30 the entire contents of the biggest fly-book would not make one of them stir a fin. For instance, Mr. R. Brookes, who published in 1740 a treatise on angling which went through numerous editions, says, "The most usual baits are a large, gaudy, Artificial Fly, Lob worms, small Dace, Gudgeons, Bleaks and Minnows which should be often varied in order to suit the Humour of the fickle Fish, for what he likes one day he will despise the next." Nicholas Cox, whose great work, "The Gentleman's Recreation," antedated Brookes by over half a century, says of the salmon, "he biteth best at 3 of the clock in the afternoon in the months of May, June, July and August," that when obstructed in their passage to the sea "they have grown so impatient that clapping their tails to their mouths with a sudden spring they have leapt clear over Wear or any other obstacle which stood in their way." Mr. Cox also says that there is " no bait more attractive of, and eagerly pursued by Salmon than Lob worms scented with the Oil of Ivy berries or the Oil of Polypodies, or the Oil of Oak mixt with Turpentine; nay, Assa-Fœtida they say is incomparably good." I give these examples, which might be indefinitely multiplied, from the earlier angling writers, to show how easily 
the novice who seeks instruction as to salmon from his library may be deceived. Indeed, it is not only the archaic authors whose information and advice are misleading - many of modern times show almost equal indisposition or incapacity to refrain from unwarranted statements as to the habits and disposition of this noble fish.

The sum total of our actual knowledge of salmon is small. Mr. Cholmondeley Pennell happily stated it in his excellent book, perhaps the best of his many angling works, "The Sporting Fish of Great Britain," I886, in a few paragraphs called "Proved Facts in the History of the Salmon," and it is doubtful if anything material has been added to them since. Here they are :-

I. Salmon and grilse invariably spawn in fresh water if possible, both the eggs and the young fry while in the parr state being destroyed by contact with the salt water.

II. The eggs are usually deposited on gravelly shallows, where they hatch in from 80 to 140 days according to the temperature of the water-eggs remaining unhatched beyond the latter period will seldom hatch at all, possibly from having been destroyed by the low temperature.

III. The eggs deposited by the female will not hatch under any circumstances unless vivified after exclusion by the milt of the male and, at least up to the period of migration, there is no difference whatever in fry bred between salmon only, between 
grilse only, between salmon and parr, or between grilse and parr. The female parr cannot spawn, but the male parr possesses and constantly exercises the power of vivifying salmon and grilse eggs. ${ }^{1}$

IV. The fry remain one, two, and sometimes three years as parr before going down to the sea, about half taking their departure at one year, nearly all the others at two years, and the remainder, which are exceptional, at three years old.

V. All young salmon fry are marked with bluish bars on their sides until shortly before their migration, up to which period they are parrs; they then invariably assume a more or less complete coating of silvery scales and become smolts, the bars, or parr marks, however, still being clearly discernible on rubbing off the new scales.

VI. The young of all species here included in the genus Salmo have at some period of their existence these bluish bars, and consequently such marks are not by themselves proofs that fry bearing them are the young of the true Salmon (Salmo salar).

VII. Unless the young fish put on their smolt dress in May or early in June, and thereupon go down to the sea, they remain as parrs another year, and without smolt scales they will not migrate and cannot exist in salt water.

VIII. The length of the parr at six weeks old is about an inch and a half or two inches; and the weight of the smolt before reaching the tidal wave from one to two ounces.

${ }^{1}$ This is to be understood as referring to the specific characteristics of any of the salmon thus bred. It seems very possible that there may be in fry, variations of size or development depending on their parentage or generation, as there are also known to be differences in the size of the eggs of different breeding fish dependent upon the size and age of the latter. 
IX. In at least many cases smolts thus migrating to the sea in May or June return as grilse sometimes within five, generally within ten weeks, the increase in weight during that period varying from two to ten pounds, the average being from four to six pounds, and these grilse spawn about November or December, go back to the sea, and (in many cases) reascend the rivers the next spring as salmon with a further increase of four to twelve pounds. Thus a fish hatched in April, 1854, and marked when migrating in May, 1855, was caught as a salmon of twenty-two pounds' weight in March, 1856.

$X$. It appears certain, however, that the smolts do not always return during the same year as grilse, but frequently remain nine or ten months in the sea, returning in the following spring as small-sized salmon. ${ }^{1}$

XI. It has also been clearly proved that, in general, salmon and grilse find their way back to spawn in the rivers in which they were bred, - sometimes to the identical spots, - spawn about November or December, and go down to the sea as "spent fish" or "kelts" in February or March, returning, in at least many cases, during the following four or five months as "clean fish" and with an increase in weight of seven to ten pounds.

These "facts" have to be modified to fit the conditions of salmon existence in this country, where the lives of the fish are subject to quite

${ }^{1}$ It will thus be seen that the fry of the salmon are called parrs or parr until they put on their migratory dress, when they become smolts and go down to the salt water; grilse, if they return during the first year of their migration; and at all other periods, salmon. 
different climatic influences from those which prevail in Great Britain. At the breeding establishment of Stormontfield on the Tay, where intelligent observation of the habits and growth of salmon have been carried on for about half a century, large numbers of smolts which had been marked by cutting off the adipose fin were retaken as grilse after absence in the sea of somewhat over two months and weighing six to nine pounds. It was also discovered that while the larger proportion of the young salmon assumed the silvery coat and went to sea the second year of their lives, the remainder which had been hatched from the same lot of ova taken from the parent fish at the same time, and had been subject to exactly the same conditions, remained another year in the ponds before changing to the migratory coat. That this can be ascribed (and the same thing has also been observed in the Severn) to such conditions varying from the natural ones under which the Stormontfield fish pass their early lives, is improbable, and it is likely that the divided migration of smolts to the sea is based on some natural provision analogous to that which governs the divided migration of salmon from the sea to the fresh water. I have learned that on 


\section{History and Habits}

the Restigouche River in Canada in some years large numbers of smolts are taken by the Indian boys fishing for trout at the head of the tide near Campbellton very soon after the ice breaks up early in May. The usual season for the migration of smolts is three to four months later, and until then the river is full of parr. These smolts which are migrating in May are probably from the same crop of parr of which a portion went to sea the August before, though this cannot be definitely affirmed owing to the lack of provision for confining the parr until they assume the silvery coat as is done on the Tay. Certainly some accurate knowledge as to the divided migration of smolts on this side of the Atlantic is well worth the attention of fish culturists. It is, of course, possible that there may be here, as in Britain, fresh salmon entering the Canadian rivers in the late autumn, spawning when the rivers are frozen over, and returning to the sea in the spring. There is evidence that this visitation takes place in some rivers, where fresh-run salmon have been taken through the ice. I know two credible Indians who caught one of sixteen pounds when fishing for trout with bait in December, and it seems strange that the kelts which are so numer- 
ous on many of the Canadian rivers in June can be the fish which left the sea a year or thereabouts before and spawned in October. If they are, their appearance as kelts in the late spring and early summer would indicate a stay in fresh water of six to eight months after spawning, which is very much in excess of the length of time they are known to remain there in Britain.

The British smolts return to their native rivers as grilse at periods of time varying from one to four months (provided they do not pass this stage of existence in the sea), weighing from three to ten pounds, showing a rapidity of growth fully verifying this statement in Walton and Cotton: "It is said that after he is got into the sea he becomes, from a samlet, not so big as a gudgeon, to be a salmon, in so short a time as a gosling becomes to be a goose. Much of this has been observed by tying a ribbon or some known tape or thread in the tail of some young salmons which have been taken in weirs as they have swimmed towards the salt water, and then by taking a part of them again with the well-known mark at the same place at their return from the sea, which is usually about six months later."

In this country - and by this country, in speak- 
ing of salmon, I include Canada - the stay of smolts in the sea is supposed to be at least ten months. The exception to this, if any exists, is in the case of the smolts which have been observed going to the sea in the early spring as above mentioned in the Restigouche, and they may do the same in other rivers, though I have never heard of it. These fish possibly return as grilse the same year, and could do so and still have as much time in the sea as many of the British smolts devote to that visit before seeking the fresh water. I am not aware that any of these spring migrating smolts have ever been marked so that they could be identified with returning grilse, but many of those which go down to the sea in August and September have been marked, and are known to have come back to the river in ten or twelve months as grilse, weighing from two and one-half to five pounds. I think it beyond question that the grilse ascending American rivers have averaged a much longer time in the salt water than their British relatives, and yet are smaller in weight, the conditions of both in the sea being probably nearly identical. I have never seen a grilse in Canada of above six pounds, while in Britain ten pounds 
is not a very rare size, and one is reputed to have been taken of twenty pounds.

Undoubtedly, owing to the slight differences in appearance, many small salmon, especially in this country, are assumed to be grilse, and it is . rather strange, in view of the great similarity in the fish at these two different stages of its existence, that so few writers give any instruction to enable one to distinguish grilse from small salmon. Mr. Young says in "The Book of the Salmon": "Very frequently the only distinguishing marks between grilse and salmon are the smaller scales of the former, and longer and larger fins. The fins of a grilse of eight pounds' weight are longer and larger than those of a salmon of the same size."

Other differences are the looser setting of the scales, which are more easily rubbed off in the grilse than in the salmon, and the squarer tail of the adult fish, that of the grilse retaining the forked shape of the smolt's to a marked degree. The grilse is smaller in proportion at the root of the tail than the salmon. With these peculiarities borne in mind, it is not hard to tell salmon from grilse, especially in this country, where the latter seldom attain enough size to be mistaken for their older relatives. 
So far as my experience goes in this country the size of the grilse of different rivers is about the same and does not vary according to the size of the parent fish, as is said to be the case in Britain. The grilse of the Restigouche and Metapedia, in both of which rivers the salmon average fully twenty pounds, and not infrequently attain a weight of forty pounds or over, are no larger than those of the Nepisiguit, where the average weight will hardly exceed half that of the first-named streams. Mr. Day in his "British and Irish Salmonidæ," quoting from Professor Brown Goode, says, "The male grilse is sexually mature, but not the female in America." This is certainly a mistake, as female grilse are known to breed in some Canadian rivers. The present owner of the Godbout, Mr. Manuel, is my authority for stating that on this river grilse are very frequently taken with ova quite as fully developed as those of salmon at the same time. On the Restigouche, where I have fished for nearly thirty years, I have never seen or heard of a female grilse, and believe that no members of the fair sex ascend that river until they become salmon. John Mowat, the former head guardian of the Restigouche, and an observant and intelli- 
gent man, told me the second time I was on the river that no female grilse ascended it, and for many years I had every one examined that was caught, without finding a single female. The same, I was told by an old half-breed canoeman of the Nepisiguit, is true of that river, in which grilse come up with the first run of salmon and are very much more abundant than on the Restigouche, where they do not begin to run until July, and are never plentiful then. The observations on these and other American rivers are not extensive and careful enough to establish with certainty the facts as to the sexes of grilse, though I believe that very few, if any, female grilse ascend the Restigouche.

Another curious fact about grilse which has been observed on both sides of the Atlantic, is the great relative disparity between them and the salmon in different rivers, - in numbers. It is, of course, impossible to make more than a wild guess how many grilse there should be to one salmon in the same stream, supposing all those belonging there should ascend it simultaneously, but it is certain that some rivers have in them every year many more grilse than salmon, which would seem to be the proper state of affairs, 
while others have many more salmon than grilse. In some streams the grilse come along with the first run of salmon, and in others six to eight weeks later. A river which has a large proportion of grilse may not have so many salmon as one in which the grilse are scarce. All this would seem to indicate that fish in the grilse stage come back to their native rivers in varying proportionate numbers, or that the grilse of one river go to another at that period of existence. This latter theory would account for the presence of large numbers of grilse in one river whilst another near by has but few, as is the case in the Nepisiguit and Restigouche. It is known that salmon have forsaken their own river and gone up another for one year. I have seen an undoubted example of this, and there is no reason why grilse should not do the same. However, this is a sporadic action in salmon, and the disparity in numbers between them and grilse in different rivers is habitual. In the Tweed, according to Mr. Willis Bund, in his most valuable and interesting book "Salmon Problems," "from I 808 to 1853 in no year were less than three grilse taken for each salmon, from 1853 to 1876 only two grilse were taken for each salmon." 
There has in the Tweed, in the past fifty years, been a very sensible decrease in the number of salmon, of which the smaller proportion of grilse may indicate that the fish in that stage of growth, or possibly the preceding one, had been subject to some untoward influences. However this may be as to the Tweed, there are British rivers and rivers in America wherein the numbers of grilse seem utterly without bearing on the numbers of salmon. One habit they have seems to prevail in both countries - they do not seek, nearly as generally as salmon, to reach the head waters of the rivers they frequent, and this is rather strange, as they seem by reason of their smaller size and greater activity much better able than the adult salmon to travel in shallow and rapid water.

The number of grilse taken on the lower waters of salmon rivers is, so far as I can ascertain, larger in proportion to the salmon, than on the upper waters, and this difference is quite plainly to be observed in stretches a few miles apart. It may be interesting to give the number of salmon and grilse in some waters I fish,- on the Restigouche River, - and also the number and percentages of the different fish taken in the waters of the Ristigouche Salmon Club for twenty years from and 
including $188 \mathrm{I}$. Probably the proportion of grilse would be greater in both instances were the angling carried on beyond August 15, the beginning of the close season. Our water was not fished in the seven years given at a later average date than July ro, whereas there was some fishing done on the water of the Ristigouche Salmon Club during the entire season.

\section{SALMON GRILSE}

\begin{tabular}{|c|c|c|c|}
\hline Our water, -1895 & 87 & I I & first grilse taken July 4 \\
\hline 1896 & 315 & $3^{8}$ & first grilse taken June 29 \\
\hline I897 & 120 & no & \\
\hline 1898 & 62 & 6 & first grilse taken July 3 \\
\hline 1899 & $5^{2}$ & 13 & first grilse taken July 3 \\
\hline 1900 & $\mathbf{5 5}$ & I6 & first grilse taken July 2 \\
\hline IgOI & I 79 & 5 & first grilse taken June 36 \\
\hline & $\overline{970}$ & 89 & Percentage of grilse $8 \frac{40}{100}$ \\
\hline
\end{tabular}

Ristigouche Salmon Club from r88I to I900:9986 salmon; 1 I98 grilse; percentage of grilse, 10.7 1 .

The excess of percentage of grilse in the score of the Ristigouche Salmon Club may be due to the later date of fishing on its waters or to the habit which prevailed there at one time of counting as grilse all fish below a certain weight, eight or ten pounds.

While the comparative scarcity of grilse in 
some rivers is an unnecessary confirmation of the fact of a divided migration of salmon at this stage of their existence, and it is now well established that this divided migration occurs in all stages of growth from the smolt to the adult fish, the great surplus of grilse over salmon in some of our rivers is hard to explain. One river may yield one grilse to ten salmon, and another, near by, one salmon to four or five grilse. As the fewest grilse are found in the rivers of this country, so far as I know, which produce the largest fish, it may be possible, though I only hint at it as a theory, that the large average growth attained by the salmon of the Romaine, the Cascapedia, and some other rivers is due to their continued residence for years in the sea, where their increase in size is not checked by the exercise of the reproductive function and the severe strain it involves. This would appear to show that a very much larger proportion of the fish of some rivers pass the grilse stage of existence at sea than is the habit with natives of other rivers, or, that the grilse of some rivers ascend other streams than those in which they were born.

It is probable that the smolts of this country 
remain a good deal longer in the sea before returning as grilse (and this by reason of most of the American salmon rivers being ice bound for four or five months of the year) than in the British rivers. For all this they are not so large as their European brethren. Mr. Pennell mentions the average weight of grilse as four to six pounds, and I think that nearer three than four pounds would be the average here. While it is possible that the smolts which go to the sea in August and September may return while the ice is in the river or before the next summer, none has ever been seen during this period of time, while several smolts which were tagged in August on the Restigouche have been caught as grilse the next July and were of the average weight - a little over three pounds.

After the grilse becomes a salmon, he is likely to come to fresh water every year of his life and, if not prevented, to his native river, though that a portion of the salmon of all rivers remain in the sea every year is well established, and is a precaution of nature against the entire destruction of any one crop of fish. The habits as to the ascent of the rivers vary greatly. In some, there is a run of large fish, entirely females, which enter the 
fresh water as soon as the ice is out and go straight through to the head waters of the rivers. This run will be on the rivers of the Bay of Chaleurs in which it occurs, from the middle to the last of May - this is followed during the first fortnight of June (in an ordinary season) by another run of good-sized fish and to them succeed the smaller ones and the grilse, though occasionally there is a late run containing a scattering number of large salmon. On other rivers in the same district no fish come until nearly or about July I, and then observe no order in their appearance, great and small coming together, and on more than one river the grilse accompany their elders. Undoubtedly fresh salmon come in from the sea until the rivers freeze, but in numbers very much smaller than those of the early runs. One of the best runs of salmon in the Miramichi River comes in August, when the upward migration has practically ceased in the neighboring rivers, and I think there must be a still later run in some other streams which remains as far up them as the thickness of ice will permit, spawns beneath the ice, and furnishes the kelts which come down in May following; for these kelts cannot be the fish which spawned the October 
preceding and had an open route to the sea at any time after.

The plentifulness or scarcity of salmon in good rivers is dependent largely on causes connected with the habit of divided migration which may have been operating for several years before the effect is manifest on the river. A widespread calamity to the parr or smolt crops of a certain year may cause a scarcity of salmon three years later and an average diminution of size in those taken for several years after that. While certain companies of salmon go directly through to the tops of the rivers they ascend, others, bound for the same points, take it more leisurely and halt a day or two or longer in favorite resting-places, where they take their diversion in leaping from the water, seizing flies, false or natural, on or near the surface, and amusing themselves according to the various fancies which may strike them. A rise of water may take them up river a few miles, though in larger streams they are not dependent on this and travel very often in water which is falling. So soon as the salmon leaves the sea does his appetite, which must be of the most voracious character, begin to decrease, and fortunately, as no good salmon river that I know 
could furnish food for the throngs which ascend it. That his tendency to eat is not eradicated while in fresh water is certain. He takes flies, natural and artificial, and other objects as well, with the general intention of swallowing them. That he sometimes carries out this intention I thoroughly believe, both from having taken several which had the fly far down toward the stomach and from the following incidents in my knowledge.

In 1886, late in August, two Indians of my acquaintance came down the Metapedia River and stopped at the large pool at the mouth to fish for trout, which gather there in great numbers late in the season. The canoe was anchored, and the bait, consisting of a chunk of raw beef put on a large hook attached to a string line, and a short, stiff pole cut in the woods, thrown overboard. Before it had sunk a yard and a half in the clear water the Indian in charge saw a large fish come from the bottom and seize it. Recognizing it for a salmon at once, he gave a mighty jerk, then passed the rod back to his companion, caught the line in both hands, and before the astonished fish had a chance to turn he was hauled into the canoe and on his way down the river to the sea whence 



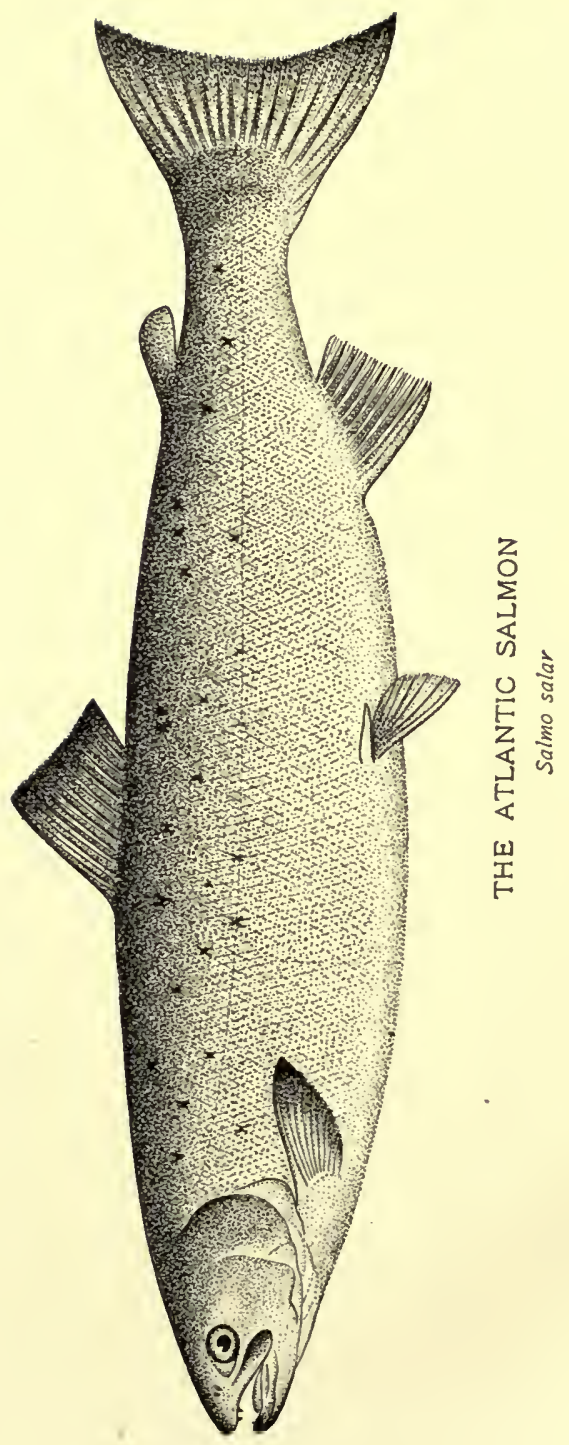




\section{History and Habits}

he had come. The salmon was about seventeen pounds' weight, and his dark color showed he had been for some time in fresh water. A bright salmon was taken a year after this by an Indian fishing for trout with bait just above the tide head in the Restigouche. A young friend of mine took a salmon with a fly on the Upsalquitch, which had in his stomach a small mass of angleworms. Any one angling in rivers that are netted at the mouth must have noticed that the fish which have been in the nets and escaped will take the fly much quicker than their unscathed companions. May it not be that as the wounded fish reach the stage of convalescence their appetite revives, and the needs of their systems, to make up for the waste caused by their injuries, excite them to extraordinary exertions to appease it?

Many instances have been known of fish taking the fly when so badly hurt as to make it seem almost incredible that they should want to move. I took one which had lately lost a good pound of flesh by a seal bite and saw one of twenty-three pounds taken, which I afterward learned had been hooked, played, gaffed, and lost the evening before about half a mile below. In addition to the fly embedded in his jaw with a yard of gut fast 
thereto, he had a deep open gaff wound in his shoulder. It would seem as though the pangs of hunger drove this fish, sick and sorry as he was, to his second and fatal attempt to devour an artificial fly. One Mitchell, who was engaged in building the section of the Intercolonial Railway which passes Metapedia, assured me he had caught a salmon with a partly digested frog in his stomach.

The explanation of the fact that salmon, even those caught in salt water, are so very rarely found with any food inside them, is that they have in common with some of the higher forms of creatures the power of emptying their stomachs when danger is near and their activity is to be called in play. They have certainly been observed in this act on more than one occasion. This conduct on the part of the fish is much more reasonable than that of never taking any food when out of the sea; and though the appetite of the salmon gradually diminishes after he reaches fresh water, it is pretty certain that he takes an occasional slight refection up to the time of spawning.

It is not in accordance with well-known facts to accept the very frequent statement that salmon rise to a fly which resembles no living creature, 
simply for purposes of investigation, and with no intention of eating it. The fact is that most flies do resemble very strongly, in a general way, wellknown moths and butterflies. The Durham Ranger, Toppy, and Brown Fairy, for instance, are excellent imitations of insects common on American or British rivers, and the natural voracity of salmon is such that, even when it is on the wane, they are liable to come at almost any moving object. A red squirrel was once being carried down a pool in the Restigouche which I was fishing, and forty or fifty yards below me was taken by a large salmon - at least there was a big rise just where we were watching the little animal, and it disappeared to come to the surface again in a short time ten or a dozen yards further down. He was not "mistaken for a shrimp," as we so often hear, to account for salmon taking a fly. Once when fishing the Chain of Rocks pool I saw a salmon with great eagerness take one of the large black and yellow butterflies so common in July, which I dropped in the current and which floated down over him. I then caught another of the same insect, put it on a hook, and cast over the fish ineffectually. Going down the river directly after, I met a friend on his way to 
Chain of Rocks to whom I told the story and the location of the fish. He got him the same evening with one of the live butterflies. The largest salmon I have ever seen on the Restigouche was taken by a man named Alford, who had risen him one evening two or three times to a Silver Doctor. He then attached to the hook of the same fly a piece of caribou skin with the hair on, and at least two inches long by one wide, and let it float down over the fish. It was taken so greedily that the hook fastened at the very root of the tongue, and as Alford was alone and had no gaff, he beached the salmon, which weighed forty-five pounds. Mr. Locke, in "The Tweed and Don," says, "As an illustration that salmon when in the humour will take anything, a few seasons ago a friend of mine captured two or three fish with the thumb of an old kid glove stuck on a plain hook." This would be a European adaptation of the caribou skin, and to my mind confirms the belief that salmon rise to a fly or to anything else with an intention of eating the object. The intention may change on investigation, as is the case often with people who think they will take something and then alter their views.

The assumption that because nothing is found 
in the stomachs of salmon therefore they never feed has very slight foundation. Many salmon are caught in salt water, and these are quite as empty as those taken in the rivers above. Any one who has taken salmon with a shrimp bait cannot avoid the belief that they take it for food, otherwise why do they swallow it? I have seen in Ireland salmon taken with shrimp, worms, eel's tail, and a spinning minnow. There are a few known instances of food having been found in the stomachs of salmon, and certainly one in which salmon when netted were seen to disgorge quantities of sand eels.

The fish of the early runs, and up to August certainly, spawn in various parts of the rivers, generally on the gravelly bars where the eggs are deposited and impregnated, in troughs or grooves dug out with infinite pains by the fish, and afterward covered by them. After this function is performed, they shortly descend to the sea, changed from the plump, brilliant creatures of a few months since, into lank, slimy, black objects, there to regain in the unknown quarters they inhabit, their health and strength, and to return in one, two, or three years perhaps, to encounter again the fresh perils of their renewed journeys. 
Where they go during these marine sojourns is a mystery likely to be long insoluble. It is thought by many that they do not go a great distance from the mouths of their native rivers, and the fact of their almost uniform return to these makes this conjecture a probable one in default of any actual knowledge to the contrary. It was discovered many years ago in Britain that salmon about visiting fresh water strike the coast at some distance from the rivers to which they are bound, and follow the coast along to their mouths. This knowledge has been utilized by the netters, much to the discomfiture of the poor fish, whose perils have been doubled. The same is true of this country, and the salmon of the rivers flowing into the Bay of Chaleurs are decimated by nets set in the sea as far as fifty miles down the coast from the estuary of the Restigouche. The returns of salmon caught by the netters are notoriously untrue, but it is probable that the nets below the estuary take quite as many fish as those set in and above it, and are doing their full share toward rendering worthless the many splendid salmon streams tributary to the bay.

It is not now considered certain that salmon 
when visiting fresh water always return to the rivers in which they were spawned. They probably do so when nothing interferes to prevent; but when, from various causes, they cannot get into their native streams it would certainly be natural, if not unavoidable, for the gravid fish, whose first instinct is to reach a place where they can deposit their spawn, to go to some river they could ascend if the entrance to their native one was practically closed. An excessive number of nets at the mouth of a river may cause salmon to desert it while thus obstructed. For several years of my acquaintance with the Restigouche River the white porpoises have been in such great quantities at its mouth as to drive off the salmon of the earlier runs, which undoubtedly went to rivers on the other side of the bay. In I 896 there was a run of large fish in the middle of July in the Restigouche which were very different in their appearance from the natives of that river, being shorter, thicker, especially at the base of the tail, and with much broader tails for the size than were found in the Restigouche fish. They came in the river all together and were past the lower waters, in two or three days, - I took half a dozen of them, all from twenty to twenty-five pounds, - but they did 
not rise freely until they reached the head waters, where a great many were killed. On the Metapedia River, where the fish are large, many of them go a long distance up and spawn in small streams. A former owner, acting on a peculiar theory of his, had a dam built thirty or thirty-five miles up the river to stop the further passage of the fish, and thus improve his own angling, at the same time forcing the fish to spawn in the lower stretches. The result of this was that in three years there were no fish in this magnificent river, and in the first year the angling began to decline. When the river came into the possession of the Ristigouche Salmon Club the dam was removed, and the salmon allowed their old freedom of action, but it took five or six years to get back the river to anything like its old form. It seemed as though, after two or three seasons' futile attempts to reach their old spawning grounds, the remnant of the salmon abandoned effort and went elsewhere.

A well-known and observing angler, writing me from Edinburgh, says anent salmon returning to their native rivers: "Fourteen years ago I rented the Mount Clairy fishings on the Deveron, which usually yielded about one hundred salmon to the 
rod. The season was an unusually dry one. On the removal of the nets the salmon were seen in great numbers at the mouth in September, and the tacksmen who had done badly, foretold, if rain only came, a grand year for the rods. Unfortunately there appeared a great number of porpoises, the fish disappeared, and very few ascended the Deveron, though rain fell a few days after the nets were removed. My total bag for the season was only six salmon."

More proof, if necessary, could be brought as to salmon not always confining their visits to the rivers in which they were spawned, but enough has been said in support of a now quite general belief that such is the fact.

Mr. Atkins, the fish culturist of Maine, has ascertained by experiments at Bucksport, where the hatcheries are situated, that the Penobscot salmon spawn only every other year. This is not an established fact in all rivers, and gives, perhaps, grounds for the supposition that these salmon may visit other rivers in alternate years, though it is hardly probable that such is the case.

As it is only in salt water that salmon, after the smolt stage, gain in weight, and especially just 
after the first seaward migration, it would be interesting to know on what food they feed, that they wax so fat - as the smolt is but a tiny creature from three and a half to seven or eight inches long, and must have the material for his stupendous growth very handy to enable him to increase his size thirty or forty fold in six or eight weeks. Professor Huxley believes that the food consists chiefly of a class of small crustaceous creatures found in semi-solid masses upon the surface, frequently of deep water, in fact that the salmon swims in a species of animal soup in which it has merely to open its mouth and swallow what enters it.

Mr. Cholmondeley Pennell gives in his "Natural History of the British Salmonidæ," published in the Badminton Library, the actual weight of seven marked grilse from the Stormontfield ponds which were let out to go to the sea in May and June and were caught from July I to August 4 of the same year - the smallest weighed three pounds and the largest nine and a half pounds.

The smolt is two or three weeks in changing from the preceding parr stage, which consists in assuming a coat of silvery scales. When this is 
done the fish gather in shoals and drop down stream till the sea is reached.

In the Fishing Gazette for September 2, I893, is a table by Mr. E. Sturdy for estimating the weights of salmon by their inches of length, of course assuming the fish to be in average condition. As these trials were made on one river and for a part of one season only, by Mr. Sturdy, it might not be safe to base any general law on them. The table is as follows, and I have, in giving it, not gone into the fractions of pounds in the original, but simply put down the approximations to quarters of pounds:-

"A fish of 30 in. weighs $12 \frac{1}{2}$ lbs. A fish of 31 in. weighs $12 \frac{3}{4} \mathrm{lbs}$. A fish of 32 in. weighs $14 \mathrm{lbs}$. A fish of 33 in. weighs $15 \frac{1}{2}$ lbs. A fish of 34 in. weighs $16 \frac{3}{4} \mathrm{lbs}$. A fish of 35 in. weighs $18 \frac{1}{4}$ lbs. A fish of $36 \mathrm{in}$. weighs 20 lbs. A fish of 37 in. weighs $21 \frac{3}{4}$ lbs. A fish of $3^{8}$ in. weighs $23 \frac{1}{2}$ lbs. A fish of 39 in. weighs $25 \frac{1}{4}$ lbs. A fish of 40 in. weighs $27 \frac{1}{2}$ lbs.
A fish of $4 \mathrm{I}$ in. weighs $29 \frac{1}{2}$ lbs. A fish of 42 in. weighs $31 \frac{3}{4}$ lbs. A fish of 43 in. weighs 34 lbs. A fish of 44 in. weighs $36 \frac{1}{2}$ lbs. A fish of 45 in. weighs 39 lbs. A fish of 46 in. weighs $4 \mathrm{I} \frac{3}{4}$ Ibs. A fish of 47 in. weighs $44 \frac{1}{2}$ lbs. A fish of 48 in. weighs $47 \frac{1}{2}$ lbs. A fish of 49 in. weighs $50 \frac{1}{2}$ lbs. A fish of 50 in. weighs $53 \frac{1}{2}$ lbs."

It is my impression that there may be very sensible variations from this table, particularly in large fish, depending on the difference in condition. I once measured accurately a female 
salmon of forty-one and a half pounds and her length was exactly forty-three inches. So short and thick was she that I am sure her great weight for her length could not be taken as affording a guide to estimate the weights of other fish. As against the measurement of this fish, Mr. Sturdy took one of fifty pounds in 1900 on the Vosse in Norway which verified the standard used in compiling the above table.

Mr. Bund gives an instance of a smolt which he marked, and which was captured next season on its first return from the sea, weighing twenty pounds. This was a growth entirely out of proportion to that usual with smolts from the same ponds, and cannot well be explained from any facts within our knowledge, nor can the fact of salmon growing so much larger in some rivers than in others. The Upsalquitch River, an affluent of the Restigouche, produces salmon which will average seven to nine pounds, though a rare big one is found. For the past twenty years this river has been stocked with the fry of the Restigouche salmon, which will average fully twice as large. Certainly the millions of fry of a bigger breed put in this river ought to have made some difference in the size of its fish, but the change, if 


\section{History and Habits}

any, is imperceptible. Unless the fry of the Restigouche salmon put in the head waters of the Upsalquitch and remaining there till they attain smolthood obey some inherited instinct, and on their return from the sea pass by the mouth of the Upsalquitch and continue up their ancestral river, it is proof that they are subjected to some conditions at sea which prevent their attaining the size of the fish from which they descend. It is quite probable that there are conditions of feeding ground at sea which affect the growth of salmon, causing those of some, and frequently neighboring, rivers, to vary materially in size. I know of no case of a salmon river having the character of its fish changed by stocking it with fry from elsewhere, though perhaps the experiment has not been tried often and intelligently enough to get many specific facts on the subject. It seems, however, that it can be nothing else than a question of food, and that fry from a river producing small fish, if put in a stream which yielded large ones, would grow to be big salmon, and vice versa.

Other theories as to the food of these fish are quoted by Mr. Pennell, and it is certain that both here and in Britain the salmon, as they approach 
the fresh water, feed on various small fishes, eels, and marine crustacea. On the Gulf coast they pursue shoals of smelt and capelin as they ascend the estuaries, and create great havoc amongst these small fry, but they probably have to depend on other foods in their more permanent marine habitations. 


\section{CHAPTER II}

\section{WHERE TO BE FOUND}

When the salmon, strong, active, and brilliant in his silvery armor feels the impulse to revisit his native river, he would certainly abandon the intention could he have any idea of what lay before him in the way of nets along the shore he coasts, and far up the channel of the river he is to ascend in order to reach his birthplace. These nets on all accessible streams have, with the drifters, spearers, and other employers of illegal methods of destruction, practically exterminated the salmon from the many excellent rivers of the Atlantic coast of the United States; and the same causes are in active operation in such Canadian rivers as fish can be shipped away from at a profit. The various reports of the Commissioners of Fish and Game for the state of Maine show a most discouraging state of affairs so far as salmon are concerned. For instance, the Kennebec River, an ideal salmon stream, was divested of fish by the building of 
a dam at Augusta. The Penobscot, which could easily supply hundreds of thousands of dollars' worth of salmon at a nominal cost if the very reasonable and necessary existing laws were enforced, is fast going down under the illegal fishing and the pollution of its water by the poisonous chemicals thrown in it from the various manufacturing establishments near its mouth. The St. Croix, owing to its being partly in Canada, where the laws are not so badly enforced as with us, though quite badly enough, has done rather better, but is gradually growing worse. The Connecticut, which could easily be made to furnish a very large revenue to the state, has been stocked several times; but when the salmon returned to the river they were all caught by the netters at the mouth, in violation of the law, and, so evenly were the political parties divided, that the poachers held the balance of power, and a governor of the state told me that either party which might try to punish their depredations would inevitably be ousted from power.

The Hudson, as to which there is some doubt of its having been a salmon river, - though it has certainly in its upper waters every requisite 
for one, - was stocked with fry in 1882 ; but it was not until $\mathrm{I} 886$, four years after, that adult fish were seen in the river, and those which were taken at the Troy dam, illegally, of course, were from ten to sixteen pounds in weight. In one year, according to the late Mr. Cheney, State Fish Culturist, over three hundred fish from ten to thirty-eight pounds each were taken in nets in the lower Hudson, every one contrary to law. Fishways have been built by the state at Troy, Mechanicsville, and Thompson's Mills. I have seen but one of them, that at Mechanicsville, which was built by some incompetent person on plans of his own, and was utterly inadequate for its purpose. At this Mechanicsville dam salmon gathered in small numbers, and were caught by hooks ostensibly baited with pieces of pork, and dragged along the bottom till the "sportsmen" at the other end could feel them against a fish, when a hard jerk sometimes fastened the hook in the luckless creature. I suppose a few salmon are still taken and surreptitiously sold by the netters, and the great state of New York has had no officials who knew enough or were honest and strong enough to take means to enforce the laws which would 
have made the Hudson as productive of food at a very slight cost as twice its area in tillable land.

While much has been done by artificial propagation and stocking to prevent the extermination of salmon and to introduce them in depleted rivers, these means alone will not make a river good or keep it so. Its whole length, from mouth to source, must be watched to insure the safe ascent to the spawning beds of a sufficient number of fish to keep up the supply, and to look out for their protection while engaged in the work of breeding and finding their way back to the sea. The methods in vogue in the United States, where we have so many rivers capable of producing unlimited quantities of salmon at nominal cost, are to put the young fry in the head waters and then leave them for the rest of their short lives to their own devices. They get down to the sea all right, but when they come back for the first time they are practically all taken by the netters. The law in New York and Connecticut provides that any salmon taken by the shad nets shall be released, but of course this is never done. A netter told me he took a salmon of thirty-eight pounds just above 
Albany in 1897. The only method of stocking our rivers with salmon is to have them properly guarded their entire length, and to enforce the laws as to nets, which are now, as to the Hudson, substantially unheeded. Thirty years ago vast numbers of shad were taken above Albany in this river, and also abundance of sturgeon. Now the river is so nearly closed by nets below that no shad has been caught above Albany for the past three years, and I doubt if a sturgeon has been seen for a much longer period. This has resulted, of course, in a great decrease in the catch of both shad and sturgeon in the lower waters, and a consequent diminution, not only of a valuable article of food, but of the profits of the very men whose violation of the laws has created the scarcity.

In all countries there seems to be an irresistible impulse amongst otherwise law-abiding people to break the enactments regarding fish and game, and such have never been enforced without extraordinary efforts on the part of the state. Legislators in this country have pretty uniformly been in sympathy with the lawbreakers in this respect, ignoring entirely the important economic question of the value to the 
people of a supply of cheap and nutritious food which could be easily created by utilizing the barren waters of our rivers. The value of the salmon fisheries of the United Kingdom is estimated to be from $£ 750,000$ to $£ 800,000$ per year, and certainly those of the Atlantic coast of the British possessions in North America now accessible, under a judicious system of protection and propagation properly managed, would shortly exceed this amount in value. The Atlantic tributaries of the United States where salmon are now practically exterminated would, under proper conditions, yield an approximation to this sum in the next ten years; but until the present system of mismanagement is changed, we shall have to depend for our salmon on Canada, where the persecuted fish have a somewhat better chance than with us.

The British possessions in North America undoubtedly afford the greatest field for the salmon angler of the future of any part of the globe. Beginning at the south in the river St. Lawrence, and farther east in Nova Scotia, which has a number of small and fair rivers, and following the north shores of the river and of the Gulf of St. Lawrence up to the Strait of Belle Isle, 
there are scores of tributary rivers abounding with salmon. Many of these well up the north shore have not been tested sufficiently to allow of any just estimate of their capacities. The Miramichi and Nepisiguit are probably the best of those south of the Restigouche in the Bay of Chaleurs. This river is a large and beautiful stream running back between the provinces of Quebec and New Brunswick, a distance of over two hundred miles, with four large tributaries - the Metapedia, the Upsalquitch, the Patapedia, and the Kedgwick. It flows in a generally northeast direction and has in its entire course no falls or rapids which a canoe cannot surmount. The protection of this river was undertaken by the Dominion government in about 1870 , and the stream was leased in two divisions to Mr. (now Sir Sanford) Fleming and to Mr. Bridges. In I880 the riparian rights were decided by the English Privy Council to belong to the owners of riparian real estate, and were taken away from the Dominion government. The Ristigouche Salmon Club has since that time acquired by purchase, and by lease from the provincial government of the fishing in front of ungranted lands, a large portion of 


\section{4

the best angling on the river, and has been very largely occupied, with other riparian owners and lessees, in vainly trying to induce the provincial and Dominion government and officials to enforce the laws they have made relating to the protection of the persecuted salmon. Under the guise of carrying on a government hatchery. at the Tideway, the officials in charge have for years entirely closed one channel of the river with a net, and arranged another with a wing from the farther shore, which practically prevents fish from ascending a second channel. The nets held under government licenses are nearly all extended farther into the channel than is legal, the regulation being that only onethird of it may be covered with them, and these are very often not lifted, as provided by law, from Saturday night to Monday morning. The river under this condition of mismanagement is deteriorating, and doubtless would now be substantially worthless but for the very large sums annually expended by the riparian owners in guardianship.

If the laws were enforced on this magnificent river, it could, undoubtedly, be made in five years to produce, for a considerably smaller 
number of nets than are now licensed, three or four times the number of salmon, and the two governments of Quebec and New Brunswick could get a proportionate increase in the rentals from ungranted water fronts. They certainly would fetch it with tenfold the number of salmon in the river, and there could be no question as to the feasibility of having them there in a few years.

The rod fishing in this river now yields about one thousand to twelve hundred salmon and grilse yearly, which is nothing like what it should do. It is impossible to get any reliable statistics as to the catches of the netters, as it is their policy to return as few fish as possible. As an example of this, some years since I, with a friend and the head guardian of the river, went down to the tide head early one morning to ascertain the catch of a certain net stretched more than halfway across the channel. Three men were lifting it when we reached them, and we counted in the meshes of the net ninety salmon. I reported this to the Commissioner of Marine and Fisheries at Ottawa, and a few weeks thereafter received from him the affidavits of five or six persons, who swore they lifted the 
net in question on the morning we were there, and only eight salmon were in it, which was the largest catch of the season. One of the indications of the deterioration of a river is the diminution in the average size of the fish, which shows that an increasing proportion of the adult salmon is being taken. It is a very sure sign, even when the numbers show no decrease, as a given year's crop of small fish may be greater than those of preceding years, and a considerable proportion of its individuals may not have visited fresh water as grilse; but when fewer large fish are taken, it shows a falling off in the supply. The average size of Restigouche fish has diminished four or five pounds since 1883 or 1884 .

On the other side of the Bay of Chaleurs we have the Grand Bonaventure and the famous Grand Cascapedia. This river was long reserved by the Dominion government for the use of the governor general, but after its ownership became vested in the Province of Quebec it was leased to a club, i.e. the part of it formerly reserved. It is comparatively well protected, and full of large fish. One of fifty-four pounds was taken some years since by Mr. Dun, and the average, one year with another, is probably above twenty-five pounds. 
The rules of the club provide that if a member has a guest only one rod may be fished, and the fish killed by the guest are charged to the score of the member. Only eight fish per day can be taken by any one rod. As an instance of what has been done on this great river, Mr. Kennedy of New York fished there from June 19 to and including July 3, 1900, having with him a guest for the last four days. Some of the time the fishing was much hindered by the great quantity of logs floating down the river, and several days were broken by heavy rain.

The catch was, in thirteen fishing days:-

Mr. Kennedy, 64 salmon 1725 lbs., average $26 \frac{61}{64}$ lbs. Guest,

8 salmon 242 lbs., average $30 \frac{1}{4}$ lbs.

Largest fish (taken by Mr. Kennedy) forty-four pounds; there were five fish of forty pounds and over, and twenty-four of thirty pounds and over. The only river I know which can compare with this is the Grand Romaine on the north shore a large river, but only fishable a short distance from the sea by reason of a large fall. I have no statistics of this fishing, but the average weight is very large. I saw on one of the Gulf port steamers, twenty years since, four fish caught there, 
which a gentleman was taking home, the weights being from forty-two to forty-five pounds. Occasionally the angler has to go out to sea in his canoe in following fish hooked in this river.

The St. Anne de Monts is another good river of the north shore, where the fish run large. The Grand and Dartmouth and others in the Gaspé district are good, and the fish are of fair average size with some large ones. The Godbout on the St. Lawrence is a remarkable river. It was owned by the late Allan Gilmour of Ottawa, and is now the property of Mr. Manuel. I have before me the score of fish taken from 1859 to 1894. A catch of fifteen to twenty salmon to one rod in a day is not at all unusual. Mr. Gilmour took forty-six on July I0, I865, and Comeau (I think the guardian) took on

$\begin{array}{cl}\text { July 9, '74, } & 57 \text { salmon } \\ \text { I0 } & 25 \text { salmon } \\ \text { II } & 34 \text { salmon } \\ 13 & 40 \text { salmon } \\ \text { 14 } & 25 \text { salmon } \\ 15 & 16 \text { salmon } \\ 16 & 37 \text { salmon } \\ 17 & 16 \text { salmon } \\ 18 & 28 \text { salmon } \\ 20 & 27 \text { salmon, \&c., }\end{array}$




\section{Where to be Found}

the whole score for eighteen days, including these specified, being three hundred and sixty salmon weighing thirty-eight hundred and thirty pounds.

The nearest approach to such a day as this of which I have heard was the bag of Sir Bache Cunard on the Grimersta, in the island of Lewis, off the west coast of Scotland, which was fiftyfour fish in one day and thirty-four the day following; the average weight, however, was but seven pounds, all with the fly. The largest catch that I have heard of in Britain is that reported by Mr. Senior, of Lord Louth, on the Beauly, where he killed one hundred forty-six fish in five days whether consecutive days or not is not stated.

The fish are small on the Godbout, but so is the river, which is very broken, and fished almost, if not entirely, from the shore.

The Moisie and the Mingan, farther down, are good and the fish are large, averaging, I should say, over twenty-two pounds. The Natashquan is a good-sized stream and full of small fish of from eight to twelve pounds. The Natashquan marks about the eastern limit of the rivers which are at all well known, though a number of those between there and the Strait of Belle Isle have been fished in a superficial way. 
Two of my friends were on the Masquarrie, the Washicoutai, and the Olemancheeboo ten years since, and had splendid sport. On the last-named river one rod took sixteen fish, averaging seventeen pounds, in an afternoon from one pool. I have since been there. The banks of the pool where the sixteen fish were taken are of solid rock, affording good standing and walking facilities. Where the fish all take is an easy cast from opposite the top of the pool, which is short with a rather stiff rapid at its foot. All the fish go down this rapid after being hooked, and are killed in a deep pool just below. The year I visited this river was a very late one, and the salmon had not ascended when we left, the I 2 th of July. So we got nothing but trout and a number of the beautiful, richly colored arctic char - the first I had ever seen.

I find I have omitted in its order the St. John River, which is above the Natashquan, and is noted for the numbers of its salmon, mosquitoes, and flies. These last are the curse of the north shore rivers, and unless anglers going there are very well protected with gloves, veils, etc., and are willing to go unwashed after their hands and faces are well glazed over with tar and oil, which 
is on the whole by far the best defence against flies, they are likely to suffer more than almost any sport will repay.

The Esquimaux River in the Strait of Belle Isle is, judging from such few reports on it as I have heard, probably the greatest known salmon river. It is very large and long, without heavy falls to prevent the salmon from ascending to its upper waters. The fish are in vast numbers and of large size - perhaps not so large as those of the Grand Romaine or Cascapedia, but well up in that class. This river has been leased by Mr. J. J. Hill, who also has the St. John, and informs me that in 1900 the catch at the one stand of nets at the mouth of the Esquimaux was fiftyone thousand salmon. The St. John, in I900, fished for an average of about eight days by six rods, yielded two hundred and thirty-six salmon, nearly thirty a day - biggest fish twenty-eight pounds, average $13 \frac{15}{100}$. This year, 190I, owing to the party reaching the river rather late, the fishing was not so good, though a catch of about eighty thousand pounds was reported to have been made by the nets at the mouth. On the Godbout in I901 three rods took in twelve days two hundred and seventeen salmon. 
The vast, practically unexplored region north of the Strait of Belle Isle, extending up to Davis Strait and to the west, including a thousand miles of shore line of Hudson Bay, is undoubtedly full of salmon rivers where a fly has never been cast. I have heard vague rumors of the enormous quantities of salmon in the rivers just north of the Strait of Belle Isle, the Hamilton being especially spoken of. At the present ratio of destruction those wanting salmon fishing are quite likely to have to look as far as these remote regions for it in the next twenty-five years, but now the lack of means of transportation makes it out of the question for any to attempt going farther than the Natashquan, except by means of a good sea-going yacht, or one of the fishing schooners built for the dangerous navigation of the north shore. 


\section{CHAPTER III}

\section{TACKLE}

"A man that goeth to the River for his pleasure must understand when he goeth there to set forth his Tackles. The first thing he must do is to observe the Sun, the Wind, the Moon, the Starres, \& the Wanes of the Air, to set forth his Tackles according to the times and Seasons to goe for his pleasure \& some profit." - BARKER's “Art of Angling," I653.

THE attempts at information which are comprised in the foregoing chapters of this work I trust may in some manner prepare the reader for the more important and practical features which are to follow. There is hardly a pleasure of early spring more delightful to the angler than that of getting out his rods, reels, and lines after their long rest, looking them over to prove that everything is in good order for the approaching tests they are to undergo, to see that the lines are unfrayed and strong, that the reels work well and smoothly, that the windings on the rods are perfect, and the rods themselves are as pliant and trustworthy as they have been in past years, and 
have not forgotten their cunning gained in many an exciting contest with a lively salmon.

The spring examination is the appetizer for the coming banquet, and the imperative call for it is felt when the warm breezes from the south swell the buds, when the air grows soft and balmy, and you know that the salmon are growing uneasy in their mysterious haunts in the ocean's depths, and, perhaps unconsciously, preparing for the ascent of their native rivers. As "The Tyne Fisher's Call" in "The Fisher's Garland" for I831, begins :-

"The snow has left the verdant heights,

Which stand by rapid Tyne,

And spring invites the blithesome wights

Who wield the rod and line,"

so we, on this side of the Atlantic, feel the fever in our veins, and feed it by these preparations, as pleasant as they are necessary.

Although salmon may be taken with a poor rod and an imperfect reel, a sound, strong line is an absolute necessity. Strength without bulk is the first consideration. I am obliged to differ with those who assume that, because a dead pull of about three pounds at the end of a line will put as big a strain on the rod as any salmon ever 



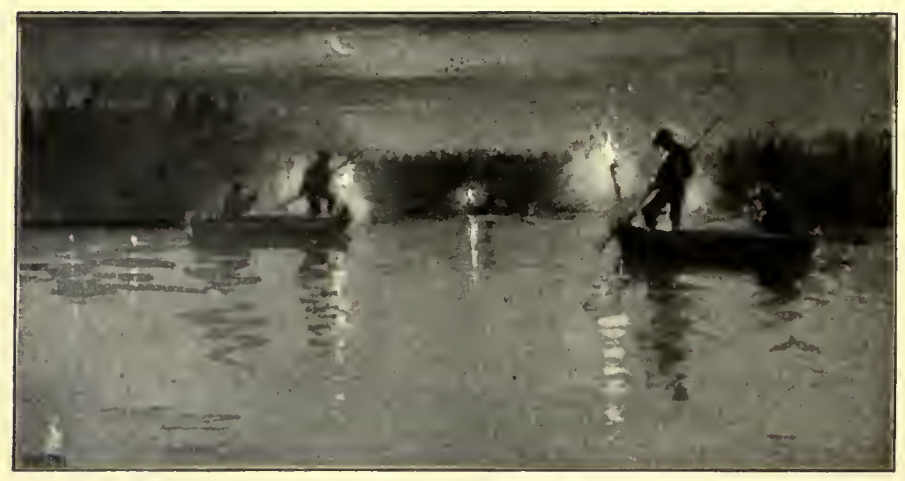

INDIANS SPEARING SALMON

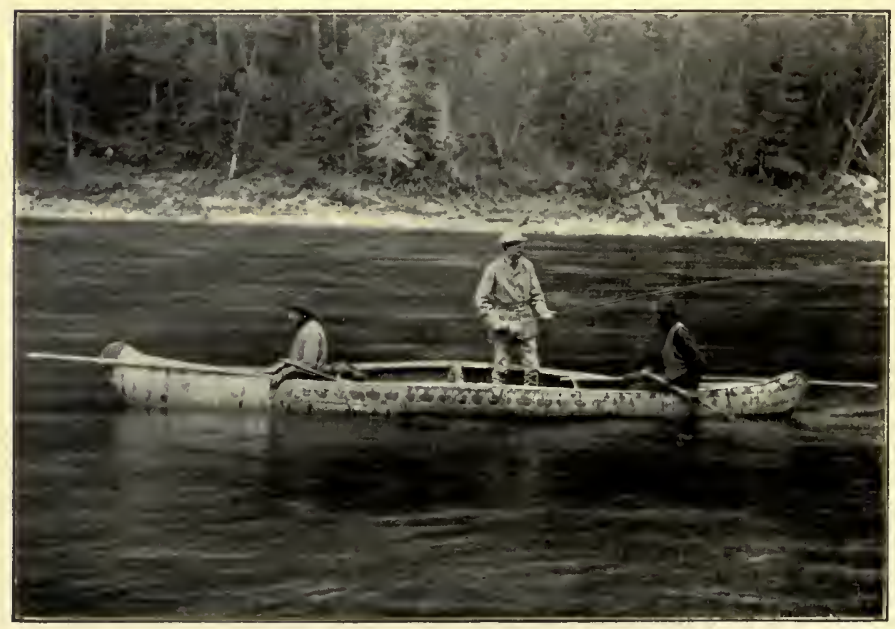

TOAD BROOK POOL, RESTIGOUCHE RIVER 
does, the pull on the line in playing a fish does not exceed the weight shown by the scale. With sometimes twenty to fifty yards of line under water the salmon will generally, if not always, get a much greater pull than three pounds, as he has to overcome the friction of the water on the line in addition to that of the bent rod and the resistance of the reel, even when going straight away. More frequently, however, he goes across-stream or in a diagonal direction to its current, which greatly increases the strain on the line. If after going down-stream the fish turns and runs up, "drowning the line," as it is called, he has to pull up against the current the whole weight of the submerged line until the angler can get below him, which is often impracticable. In these cases the tension on the line is very much greater than a straight pull of three pounds would indicate, and a large amount of effort on the part of the salmon is exerted before the result of it is felt on the rod. In towing a boat up-stream with a long line, if it becomes "bellied" by being slack and carried out in the stream by the current, a large amount of power. has to be exerted by the horse or man pulling the boat along, before the boat feels it at all, the line having first to overcome the force 


\section{6 \\ The Atlantic Salmon}

exerted against it by the current. So it is with a line of length to which a salmon is attached. Again, when a salmon after a run down or across stream turns, runs up-stream and jumps, often appearing yards above where you think he is, he has to pull out of the water the weight of the line between him and you which is "bellied" by the current and by his course, and the angler, though he have a strong pressure on the fish, may not feel it any stronger when he jumps three feet in the air. With a long bellied line out, though it is advisable to follow this rule of lowering the rod as the fish jumps, I don't believe it is effective in reducing the strain a particle, as the fish is back in the water again long before the dipping of the rod could act on the line curving between the angler and the fish and pressed downward through a long distance by a rapid current. Enough salmon break loose in their jumps to prove that on such occasions a much stronger force than usual is brought against the line, if there were no other way of demonstrating this fact. Mr. Wells, in "Fly Rods and Fly Tackle," gives some interesting and ingenious experiments as to the strain exerted in pounds and ounces by trout, which show it to be much 


\section{Tackle}

greater than would be supposed from the result given by attaching a spring balance to a line and having some one hold the rod up and pull against the balance as much as the rod would bear.

In quick water a trout of $\mathrm{I}$ lb. $9 \mathrm{oz}$. pulled $2 \mathrm{lbs}$.

In quick water a trout of $2 \mathrm{lb}$. $2 \mathrm{oz}$. pulled $2 \mathrm{lbs}$. $22 \mathrm{oz}$.

In quick water a trout of $3 \mathrm{lb}$. - pulled $4 \mathrm{lbs} .4 \mathrm{oz}$.

In quick water a trout of o $\mathrm{lb}$. $12 \mathrm{oz}$. pulled $\mathrm{I} \mathrm{lb} .4 \mathrm{oz}$.

In quick water a trout of $3 \mathrm{lb} .4 \mathrm{oz}$. pulled $5 \mathrm{lbs}$.

In "comparatively still water" a trout of three pounds four ounces pulled four pounds eight ounces. These experiments were made by attaching the spring balance to the line beyond the point of the rod.

The American braided, waterproofed silk line long bore the palm as the best one made, but this high reputation has been greatly dimmed in the past few years, during which time I, with many others, have found these lines distinctly inferior to their former reputation. They do not seem to have anything like their old durability, and after one season's use are apt to knuckle and grow very tender for a distance from the end, sometimes breaking suddenly where casual observation would show them sound. A new line has lately appeared in Britain and here 


\section{The Atlantic Salmon}

called the "Olinea," which appears very good, and possibly may prove equal to the old line. I have tried it but one season, when it was satisfactory. Lines should be selected with reference to the rods on which they are to be used, a very light line on a heavy rod being as objectionable as a heavy line on a light rod: in the first instance the weight of the line is not sufficient to bring out the spring of the big rod; and in the second, the strength of the rod not being great enough to lift a good length of the heavy line from the water.

The tapered line I do not regard as desirable. It looks rather nicely when not in use, but adds nothing to the casting qualities; and when the line is shortened by losing a portion of it, which is sure to happen, its only possible advantage over a line of uniform size is gone. Mr. Cholmondeley Pennell says he "found there was no appreciable difference in calm weather (between tapered and 'level' lines), but when casting across, or still more against a sharp wind, the 'swelled' line went out decidedly straighter and more easily." So soon as the end of a line is at all frayed or knuckles in places, and can be easily bent at a right angle even 
though it is strong and will stand quite a hard pull, then is the time to cut it off as far as the portion which is absolutely sound; for in such places the line will often break with the rushes of a fish directly after it has stood a pull of eight or ten pounds or more. It is not safe, and he who continues using it will at last do so to his sorrow. A line of one hundred yards is quite long enough for general use, and one of one hundred and twenty yards is ample for any emergency likely to occur. By cutting in two a line of one hundred and twenty yards, and having each part neatly spliced to the end of a thin linen Cuttyhunk bass line of one hundred yards, you get two lines of one hundred and sixty yards each which occupy much less reel space than one hundred twenty yards of salmon line, and are quite as strong and durable, besides being more economical. Salmon lines should be unwound from the reel and dried thoroughly as soon as practicable after being used. This can be done without taking the reel off the rod or removing the casting line, by simply pulling the line from the reel, the rod being hung on hooks or cleats, and leaving it on the ground or floor beneath in loose coils, which will soon 
become perfectly dry by exposure to the air if under cover. Lines should be tested before going into use at the beginning of the season, and frequently during use in the parts of them exposed to the water.

\section{Casting Lines or Leaders}

Every one knows that these useful and in many cases indispensable parts of the angler's outfit are made from the silkworm, though not, as many suppose, from the entrails of this creature. The gut is in reality the unspun silk of the worm, which, instead of being allowed to be used for a cocoon, is taken from the insect prematurely. The worms are selected just before they are about to begin spinning, which is known by the attendants from certain signs in the caterpillar - the cessation of feeding, and the appearance at the mouth of a small filament of silk. Mr. H. P. Wells in his book on "Fly Rods and Fly Tackle" describes at length the operation of obtaining the gut, from which I condense the following: When the worms are ready to spin they are immersed in a pickle of vinegar and water for several hours. They are then removed, seized at each end, and forcibly 


\section{Tackle}

torn apart, disclosing the two silk sacs, which are about twice the length of the worm. These are taken by the operator at each end, stretched out to the desired length, and placed upon a piece of board, where they harden almost immediately on exposure to the air. Later the gut is washed in pure water, and hung up where a current of air will pass through and dry it. When dry, the strands are tied up in bundles, and sold to those who cleanse them from the little adhering filaments of the sacs, and prepare them for market. The best gut is the longest, the roundest, and the most transparent, and, of course, the scarcest. Good salmon gut should be sixteen to eighteen inches long, though it is becoming harder year by year to get it of this length and perfect. Mr. Wells holds out a remote prospect of gut being produced in this country of a very much greater length than any now or formerly in use. He prints a letter from a Mr. Garlick of Bedford, Ohio, who states that he has produced gut from the Attacus cecropia eight or nine feet long and strong enough to hold a salmon, and quotes from an article by Mr. C. F. Orvis, an old angler and fly tier, which says, "I have in my possession a round, perfect strand 
of gut which is now six feet long, and a piece has been broken from it; it is large and strong; it was drawn from some big silkworms by a man in New Jersey." What a boon it would be to anglers if gut such as this were attainable. Chitty says in "The Fly Fisher's Text-book," "Each piece should be also to the teeth as hard as wire and transparent as glass, which testifies strength, freedom from unravelled fibres that are attended with an inclination to split or peel; knotted roughness which shows almost actual rottenness," etc. While very few anglers in this country tie their own casting lines, it is desirable for all to know how a broken leader can be mended, how to make a proper knot for the loop in the end, and how to fasten a casting line which has no loop at the end to the loop or eye of a hook.

First, I should warn all to eschew, without exception, any casting lines where silk whipping or lapping is used. This is said to prevent the knots from cutting where the strands of gut are tied; but the advantage is very questionable, and is much more than neutralized by the silk whipping growing white after a few days' use, which wears off the varnish, and the invariable loosening of the ends, always resulting in the angler 
being obliged to take off the whipping entirely, and in frequently having to retie the knots to which it was applied. I copy from the Badminton the single fisherman's knot for tying strands of gut.

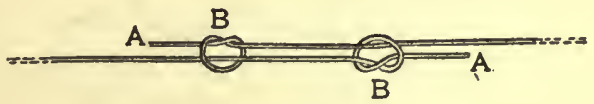

"The two ends of the gut $A A$ are laid parallel to each other, being held in that position between the first finger and the thumb of the left hand at the point and in the position in which they are to be joined. A half-hitch $\operatorname{knot} B B$ is then made by the right hand with the end of each strand alternately around the strand of the other, and each separately drawn tight." When the knot is drawn tightly together, it forms a very neat and strong union of the strands of gut, and the ends may be cut off as closely as possible. The double knot is perhaps even less liable to slip, and is the one generally used in tying salmon casts. "It is made by taking two double instead of two single half-hitches, the end with which each half-knot is tied is passed twice instead of once around the central link, and through the loop in the manner shown by the engraving." 
For making a loop at the end of the casting line the very simple one below is quite as good as any, and so easy as to be within the knowledge of any child of ten years.

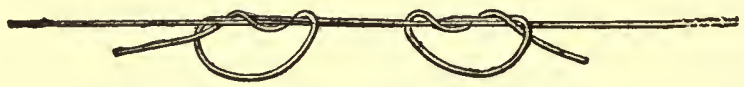

Frequently one wants to fasten the casting line to the fly when there is no loop on the former, as it makes a neater knot, and the loop is often objectionable by reason of its bulk, in low clear water. "Tippets" or single strands of gut with a small loop at one end to fasten to the casting line are much used in Britain instead of the ordinary and frequently clumsy and bulky loop. To attach the fly to one of these "tippets" or to the plain end of the casting line I have found, after many years of use, the "figure 8 knot" is the best.

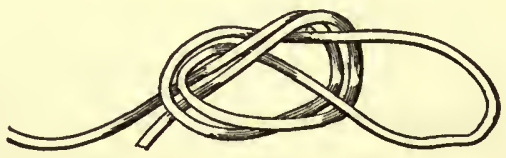

Although the knot is shown on a turn-down-eyed hook, it can be used just as well on any gut or other loop, and is the strongest and most convenient I know for fastening the casting line to the 


\section{Tackle}

reel line. In "Figure $A$ " the casting line being passed through the eye or loop, and always from the back of the hook, a half-hitch is made by turn-

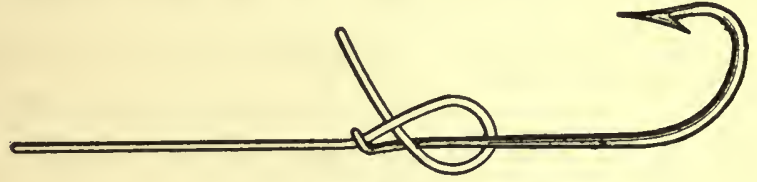

Figure A.

ing the gut once around the shank of the hook, or fly, then between the shank and the gut below the eye. In "Figure B" the knot is shown finished all but being drawn tight. The end of the gut after the completion of the half-hitch being passed around the gut beyond the eye and above, not be-

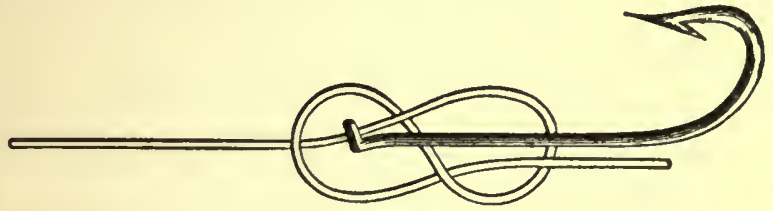

Figure B.

low, it when the hook is held in the position shown, then tuck the end through the loop first formed on the back of the hook in making the half-hitch, and holding fast the end of the gut, pull tightly the part of the line above the hook, and you have a knot which cannot come loose, is neat, not lia- 
ble to cut, and can be taken out very quickly with the end of a small sharp bodkin, or its equivalent, which no angler should ever be without. Mr. Wells says truly of this knot: "This method of attaching the flies to the leader has, I believe, many advantages. The customary loops are apt to immesh more or less air which, when submerged, shines like polished silver, while all disturbance of the water caused by the knot I advocate is so close to the fly as to be readily attributed to the motion of the fly itself. Again, it is unnecessary to pass the fly through the loop, and the injury it not unfrequently suffers from this cause is avoided."

Casting lines should not be exposed to the light or to the direct rays of the sun except when in use, nor bent at anything like an angle unless thoroughly soaked. When put away they should be wrapped in something which excludes the light (I use a piece of chamois skin), and immersed in a bowl of water four or five hours before being used. I have now casting lines that I bought ten years since which have been carefully kept, and this season they were quite as good as ever. There is a great difference in the durability of casting lines which are apparently identi- 
cal in size and quality. I once had one of several tied for me by Nicholas Brown of the Weir Cottage, Galway, Ireland, which I used for an entire season and took on it thirty-eight salmon. The gut was not extra heavy, but very hard and as stiff, when dry, as a wire of the same size would be. It is still apparently fit for service, but I am preserving it along with other "memorabilia" of my angling experiences. Good salmon gut should stand a strain of fourteen to eighteen pounds before breaking, but it is not advisable to test any the angler is going to use as highly as that, e.g. a man was once backed to eat a leg of mutton at 2 P.M. At I 2 м. his supporters were betting on him heavily; and one of them, being asked by a friend what made him so sure of victory, replied, in confidence, that his man could not lose, as they had that morning tested him on two legs of mutton, which he had finished easily.

\section{Reels}

A good reel is of the first importance in salmon fishing, and until the past few years the art of making one had practically ceased in development for half a century. However, of late, there has been very great improvement, not only in the 
materials used, but in the manufacture of this implement, and the adoption of the tension screw to regulate the pull required to take off the line has been of the greatest service to anglers. The general reduction in weight is hardly less useful, although a reel may be too light for the rod as well as too heavy. A multiplying reel, or one which may be changed from a click to a multiplier, is not thought nearly so good as the plain click reel. A wide spool on a reel is objectionable on account of the tendency of the line, when reeling in rapidly, to become unevenly distributed on the spool, when the coils which are above the general level are apt to slip down and cover a part of the line more lately reeled in, fouling it so it will not render. With a narrower barrel to the reel this risk decreases, but still exists in a modified form; and one should, in the most exciting period of taking in line, try to so guide it with the thumb of the left hand that it is evenly wound on the barrel of the reel. It is easier to do this when the reel is on top of the rod in playing a fish, as it uniformly is in this country, than when it is kept underneath, both in casting and when a fish is hooked, as is generally the British custom. To my mind, the advantages of our 
method are: first, the rest to the rod from having the strain on it changed by turning it over from the position in which it is used when casting; second, the saving to the line by the decrease of the friction against the rings by the employment of the American method; and third, having the reel in much plainer sight at the time of its hardest work. Still, the majority of the best anglers in the world keep the reel always underneath.

Returning to the width of the reel, a very narrow one is not so good as one of from $1 \frac{1}{2}$ to $1 \frac{3}{4}$ inches' width of barrel, and about $3 \frac{1}{2}$ to $4 \frac{1}{4}$ inches outside diameter. A reel of these dimensions will hold one hundred yards of fair-sized line, say No. 2 or 3 , and more than that if the lower half of the line is of linen. By the tension screw, which is on the side of the reel opposite the handle, the pull may be regulated, but should always be kept easy, as a hard-running reel will not only wear out more quickly, but one is more likely to lose fish with it. It is noticeable how much less likelihood there is to overrun in the more modern reels than in those of former days, even when without the tension screw. When a reel clogs from heating of the interior mechanism, by plunging it in the water it may frequently work all right again. 


\section{Hooks and Flies}

When a salmon rises and takes a fly, closing his mouth tightly on it and turning to the bottom with the hook sometimes well down toward the root of his tongue, he is pretty certain to drive the barb of it far enough into him to make his capture moderately certain. In such cases a slight difference in the angle of the penetrating line is not important; but there are many instances where the fly is very slightly nipped or touched by the fish, and for such, the hook with the most acute angle of penetration will fasten the most fish, other things being equal. Mr. Cholmondeley Pennell, in his "Modern Practical Angler," has treated the subject of hooks most ably and exhaustively, and any one interested in the subject should not fail to read what he has written. The treatise on "Fish-hooks" in Mr. Wells's "Fly Rods and Fly Tackle" is also entertaining and instructive. Mr. Cholmondeley Pennell states that the objects to be aimed at in a perfect hook are, (I) penetration, (2) holding power, (3) strength, (4) lightness and neatness, and thinks the best combination of these virtues is found in the hook called the Pennell. I should 
place, along with the Pennell, the O'Shaughnessey and the Limerick. Of course, if a man fastens a good proportion of the fish which rise to him, he naturally ascribes it to his own skill or to the hook he is then using, being liable to overlook the fact that the salmon may be rising with the determination to take the fly; and, on the other hand, a hook may be condemned because the fish are rising at it more in sport than in earnest, and consequently few are fastened.

Hooks are known by sizes, and it is important for the angler to keep these in mind when ordering flies. The turn-down-eyed hook is justly gaining in popularity, and I think it safe to venture the prediction that ten years hence the plain shanked hooks for fly fishing, especially for salmon, will be as rare as hammer shotguns are now. It will be a blow to fly tiers, as the gut loop used to attach the casting line is in nineteen times out of twenty the first part of the fly to give way, and once broken or frayed, the fly is useless. This is entirely obviated by the use of the eyed hook, which will insure a double or treble average durability to the fly, a most important item to the angler. Besides the advantage of durability, the eyed hook can be fastened to the casting line 
much more neatly than one with a gut loop. Of course the loop at the end of the casting line cannot be used and must be cut off, or the fly attached first to a "tippet" which may be looped on the casting line. The attachment of the tippet, or of the casting line, to the eyed hook (and

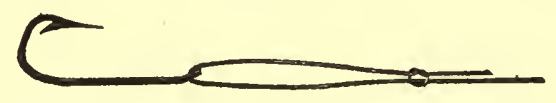

that with the eye turning down is the best) may be made by the figure 8 knot shown on p. 65 , or as by the cut below which shows the jam knot. This is recommended by Mr. Cholmondeley Pennell especially for trout and grayling flies, but I have used it on salmon flies with good results, though I prefer the figure $8 \mathrm{knot}$, as it seems rather more secure. When the gut has been passed through the hook eye and the slip knot

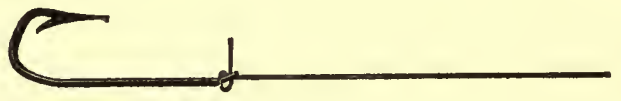

has been made on the gut above, it should be left large enough to pass over the eye, when on gradually tightening the central link the "jam knot" is formed. Of course it is necessary in this, as in all other attachments of the fly to the 


\section{Tackle}

casting line, to examine the point of union frequently to see that the gut is not frayed and everything is right. In salmon fishing this examination as to all parts of the tackle should be frequent and searching, that one may know,
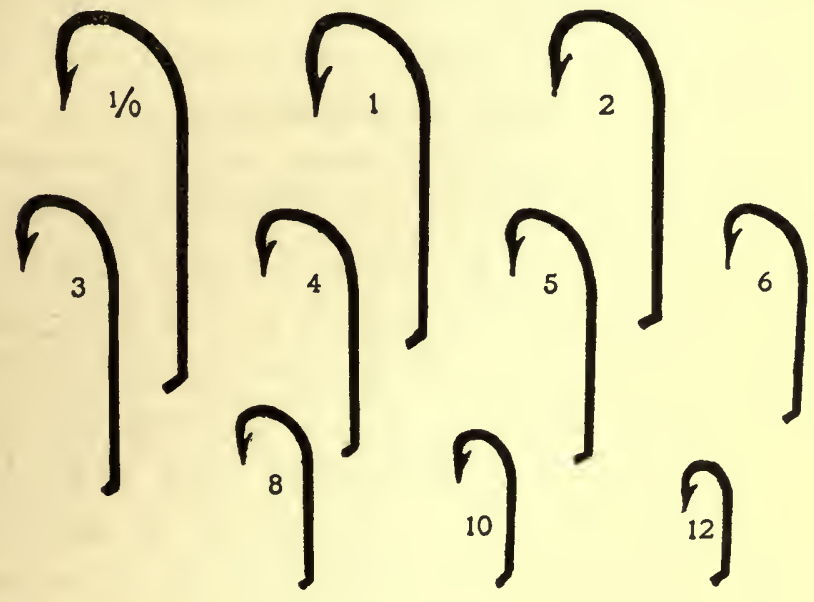

before it is too late to apply a remedy, that it is not his fault if the fish is lost.

The sizes of hooks vary somewhat in different factories, but the following diagram approximates the average sizes, from 12 to $1^{\circ}$, which latter is quite as large as any one is likely to want in this country. 


\section{Rods}

I am not at all certain that either the rod or the fly are the most important parts of the salmon angler's outfit, so far as the perfection or pattern of either is concerned. Salmon may be taken on flies of almost any pattern, size, or roughness or neatness of manufacture, and a rod may suffice for successful sport and at the same time violate nearly every one of the formulæ used by the most eminent makers. Still, a man can fish with much more comfort if he has a rod well balanced, and adapted to his strength and to his manner of casting - always supposing he has had experience enough to know a rod that suits him when he has it in his hands. If he has not, he should leave the selection to some more expert friend. A rod for use from the bank should be longer than one used from a boat, as in the latter method of fishing the boat or canoe can almost always be placed within an easy cast of the spot one wishes to reach; whereas it is frequently necessary in fishing from the bank to make casts beyond the scope of a short rod. However, in the latter method of fishing, altogether the more attractive and sportsmanlike, 



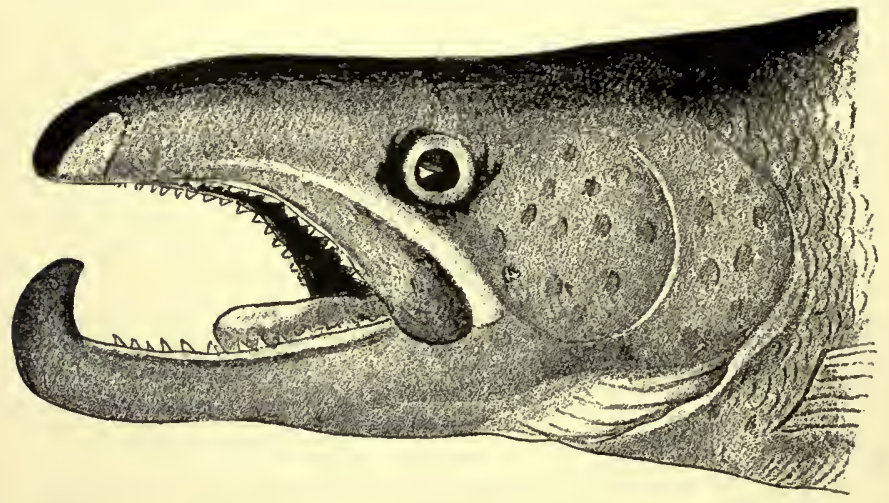

HEAD OF LANDLOCK SALMON IN SPAWNING SEASON

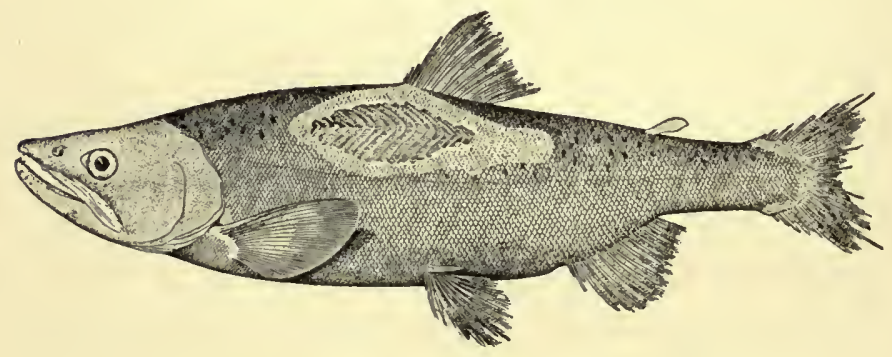

A PACIFIC SALMON AFTER SPAWNING

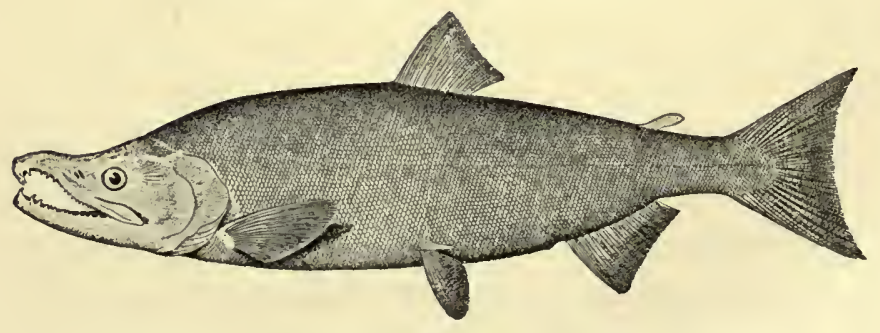

ATLANTIC SALMON DURING SPAWNING SEASON 
the British idea as to the weight and length of rods has changed very much of late; and I think few would now recommend a rod longer than eighteen feet for fishing from the bank, whereas twenty years ago those of twenty to twenty-two and twenty-four feet even were in common use. Certainly such heavy engines have no practical advantage save that of developing the muscles by unnecessary labor, and at the latter half of a long day, toil for this purpose ceases to be a pleasure. Even were rods of equal weight, the shorter would be the easier for continuous use. One often hears a person say, generally of a heavy, unwieldy rod, "What a rod that would be to kill a fish," oblivious to the fact that one rod is just as good as another in its killing powers, provided both are well enough made not to break at the strain required to hold the salmon. I know of a thirty-eight-pound fish being killed on a five-ounce trout rod, and I landed one of twenty-eight pounds on a rod not much heavier. It was rather tedious, as I was afraid to put the strain on the fish that an ordinary salmon rod would have stood easily.

The combination in a rod to be sought, and not easy to find, is one of strength, lightness, and 


\section{6}

\section{The Atlantic Salmon}

casting power that is adaptable to a short as well as to a long line. There are many rods which need a heavy weight of line to work well, and at any distance under fifteen to twenty yards are too stiff for good work. Others are so limber and withy that they are only capable of doing well at short ranges, and are useless for anything like a long cast. A properly constructed rod should have the strength equally distributed from butt to tip, so that a pull at the latter point will cause the rod to bend throughout its entire length. If the spring is confined to one-half the length, owing to the weakness of the top or stiffness of the butt, the rod is defective, as in casting the spring should be easily perceptible to the end of the butt. Top-heavy rods of the Castle Connell pattern, though possessing great power, are not pleasant to fish with, owing to the great proportionate weight of the top.

Major Traherne, one of the best anglers of his day and the author of "Salmon Fishing with the Fly," in the Badminton Library, and "The Habits of the Salmon," two most interesting and instructive treatises, says: "I have tried all sorts and sizes of rods by various makers, and the one I am now using, and have used for many years, is, to 
my mind, perfection. It is a greenheart in three splices, and if a rod is to be judged by its powers of casting, it should be a good one. It is the one with which I won the first prize at the Fishing Tournament at Hendon in July, I884, for the longest overhead cast, with a cast of forty-five yards one inch." Major Traherne does not mention the length of this rod, but I was told by Farlow, when in '86 or '87 I went to order a rod of this pattern, that Major Traherne was then using one of sixteen feet. That length being nearer in accordance with my ideas, I had one of that size made, which I still own. It is an excellent rod and apparently indestructible; but I suppose I shall be adverse to the opinions of most British anglers when I say that I prefer, for fishing from a canoe, a rod of the earlier make of Forrest \& Son of Kelso, Scotland. I have used one of these, fifteen feet long, for twenty-five seasons, and killed a great many heavy fish with it. It has been varnished a few times, and some of the whippings about the joints have been renewed; but it is as good as ever, including the two tips, neither of which has been broken. Forrest rods are used more than any others in this country, but I fear that many sent over in late years are 
not so carefully and thoroughly made as those of earlier dates. In balance and casting power up to thirty yards, which is quite as far as any one needs to throw, and generally too far for successful fishing from a canoe, as salmon are neither so apt to rise to a very long cast or to take the fly if they do, I think a good fifteen-foot Forrest rod equal to any I have seen. The American split bamboo rods have great power and are light and delightful implements to handle; but many of them have been found subject to a kind of dry rot near the joints, which develops generally after one or two seasons' use, when the rod will sometimes break at an ordinary cast without the least previous sign of weakness. This general tendency, which perhaps might be prevented by great care of the rods, has made them unpopular here, and in spite of their many advantages they are not much used. It is rather strange that trout rods made of the same material and by the same makers are as durable as any other rods. As between jointed and spliced rods, it is hard to decide, though probably the jointed ones would carry the preference. I believe, however, that a spliced rod is more even in its action than a jointed one, from having no part of it, as ferrules, 
stiff and immovable. For the same reason the jointed rod would be more likely to break at the points of union of the different sections than would a spliced one. Perhaps, however, in actual work the convenience in putting up and taking down more than counterbalances the slight advantages I have named in the spliced rod.

\section{Flies}

"Large be your fly too, with expanded wings Of various hues, at this he boldly springs."

-Williamson's British Angler, 1840.

I approach the subject of flies with the certainty that no opinions, experiences, or views on the matter can be advanced which will not run counter to those of many masters. I have never met two reasonable anglers who would not differ radically as to some of their doctrines regarding flies. It is as ticklish a minor theme to venture the expression of decided opinions upon, or to lay down hard and fast rules about, as one could easily find. Were it possible to furnish a tyro with a dozen different patterns of flies and force him to fish with them alternately for several seasons on a good salmon river, some authentic information might be gained as to which kinds 
were the favorites of the fish. However, as it now is and probably always will be, each angler has a theory or many theories of his own. If they are the result of his experience, they may be generally right, - for the waters in which he is accustomed to fish, - but quite inappropriate for water somewhere else. Again, some of these theories may be based on extraordinary occurrences, as, on a certain occasion, when nobody else was having any luck, the trial of a fly very much larger or smaller, brighter, or darker than those in use has been rewarded by the capture of several fish, which the angler is likely to assume would only have risen to the particular strange fly they took. He can't say with anything like certainty that the fish would not have taken something else just as well, but very naturally ascribes his success to some attractions in the particular fly he has used. Almost any angler has facts enough at his own command to disprove nearly all statements that may be made by others as to the virtues of special flies.

While I admit that I suffer with others from the prevailing delusions on this subject, and that in some respects I feel quite strongly in favor of my own opinion, I will endeavor to explain 
my ideas with the full belief that many of them can be successfully controverted. I am often inclined to think that the simple views as to flies held by a Micmac Indian, Jacques Vicaire, who fished with me for many years are not so far out of the way. "Wen salmon want a fly, he take any fly damn quick. Wen he don't want none, no matter how many you show him, he say go to h-_."

Perhaps I may begin by saying that, as a general rule, large flies are better in high water and early in the season, and small ones when the water is low and clear. I have seen exceptions to this rule, and fish taken on No. 3 and 4 flies in early high-water fishing, and on one occasion when we were using in July Nos. 8's and Io's in the very low clear water, I took four good fish one afternoon on a large No. 2 toppy. I knew salmon were in the pool, and had tried them in vain with various small flies for several days. When I changed to the toppy they took it at once. I would not therefore recommend a big fly of this kind for low, clear water, though a similar experiment might succeed when salmon will not take the flies appropriate to the time and place. As to the sizes of flies, what may be 
large on some rivers would be considered small on others. On the Shannon in Ireland I am informed that $8^{\circ}$ flies are used for the spring fishing. I took three fish one morning on the Restigouche with a fly I should think as large as that, which was given me by an English friend. The water was very high and dark after a heavy rain, and the fish came for the enormous bunch of feathers just as freely as they did to the No. I Silver Doctor a friend was using in the pool above me.

I am quite sure that salmon will apparently change their ideas as to the desirability of certain flies from year to year, as a woman changes the pattern of her bonnet or a man that of his cigars or neckties. Many years ago I tied a rough fly with claret body, heavy gold tinsel, yellow tail, blue hackle, and wild turkey wings. With this fly I was more successful than with any other for several seasons, of course using it more, but all at once it seemed to lose its attractiveness and has never regained it, though I give it a trial every year. Of course, if a man puts on a strange fly and gets a fish with it in short order, he will go on using it, and the more fish it takes the stronger belief he will have of its merits, not tak- 
ing it into account that he cannot be sure some other fly would not do quite as well. Major Traherne in the Badminton Library speaks of this change of mind as to flies in the salmon, and mentions one violent revolution as to what was wanted on the River Usk, in Monmouthshire, where the change has been from a fly with a dirty yellow body, blue or red cock's hackle, and brown wing, to what is called the "Usk grub," a wingless fly of tinsel chenille and coch-y-bon-dhu hackle in joints. I have tried this fly on the Restigouche often, but never with any success, though I have taken fish on a brown hackle trout fly, and on a bunch of fur from a squirrel's tail tied on the shank of a hook. The Beaufort Moth, a white-winged fly with peacock-herl body, much like the Coachman, I have used with good results for late evening fishing, from dusk until pitch dark (the best time for the long, smooth, flowing stretches), until last season, when, after vainly trying the white fly for two evenings, I changed to a "Causapscal," an all yellow fly of the same size, No. I, and had thereafter fair sport on that and some other flies quite as different from the white one. A fish may not be in the rising humor at eight o'clock, but at one minute 
past he may have reached the point where his appetite, or whatever it is which induces him to rise, impels him to take one or some particular passing fly. There is an instant when a salmon changes his mind from a state of apathetic indifference to flies in general, to a desire to seize any fly or some especial one that may be presented him. I have known of several instances in support of this statement. A friend of mine was fishing the big pool at Metapedia before the club was formed, and when it was free to all of the guests at Dan Frazer's hotel. Close behind him and in line followed two canoes, an angler in each, and all three were using the same fly, a Jock Scott. My friend fished down to the bridge without a rise, while each of the men not two minutes behind him took a good fish from the water he had just gone over. My friend had undoubtedly cast over these salmon, and had his followers taken them so soon after with different flies, he would naturally have concluded it was not the Jock Scott that was wanted. This incident proved, and I have others in my mind nearly as conclusive, that a salmon may become a rising fish almost in the twinkling of an eye, and will, so soon as the change occurs, rise to a 
fly he would not notice a moment before. I should, as the result of my own practice in salmon angling, place the size of the fly as the most important element in its selection, as I believe that very often, though not always, it is the size that first appeals to the desires of the salmon which, up to a certain point, it is our aim to consider. Salmon will very frequently take freely under similar conditions flies of one size but of very different colors, but not often flies of greatly varying sizes. Last summer I took three fish from one pool, each hooking himself at the first rise and having had no other fly over him, on a Silver Doctor, a Durham Ranger, and a Brown Fairy, all tied on No. 4 hooks. I tried the experiment, as there was a number of freshrun fish in the pool, and I wanted to give the question of size a fair trial with uniform conditions, as nearly as could be obtained.

I don't consider, however, that the result of this experiment makes it at all certain that there are not numerous occasions when a different attitude on the part of the salmon might be established. Indeed, I shall mention hereafter a notable instance or two wherein color and not size was demanded. 
Next to size, I should place color as the desirable attribute in salmon flies, and by color I mean the general effect which may be obtained by using materials of uniform hues. I do not believe that salmon are sensitive to slight variations in color, or that the addition of a minute feather or an extra twist of hackle, put in by tackle-makers to increase their list by one pattern, or by ambitious anglers in order that their names may be revered by the present and future generations on account of having flies called by them, matters one way or the other.

Sir Herbert Maxwell, in his very instructive book, "Salmon and Sea Trout," gives a number of examples to strengthen the theory that color has nothing whatever to do with fish, either salmon or trout, taking the fly, and that these fish are practically color-blind. His own experiences were with trout, which he found would take a bright blue or red May fly quite as well as one of the natural color of the insect. The May fly being about the best imitation of the real thing that exists in any artificial flies, this might prove that the trout looked first for the shape and size of the fly they were taking, and perhaps experiments with other patterns not so 
closely resembling living insects might be more conclusive if they gave the same result. Sir Herbert quotes an anecdote from Thomas Tod Stoddard of a a Scottish laird who so firmly believed that color had nothing to do with the taking properties of flies that he renounced all color in his, and dressed them entirely in white, and, thus equipped, took as many fish as one of the "ablest craftsman" in the district whose notions regarding the visual perception of fish were perfectly different. So far as our trout go, I can say with confidence they are not colorblind, though this may be answered by the statement, which is true, that they are not trout at all, but char. Salmon may be more indifferent to the color effect of flies than trout, but I am very reluctant to admit, in the face of several tests mentioned in this volume which seem to me conclusive, that this indifference comes from inability to distinguish between a dark and a light colored object or even to a finer perception of hues.

It is safe to say that in a lot of flies of fifty varieties twenty-five would be so nearly alike that a layman could not, without careful examination, tell the difference between them, and that a salmon could do better is very improbable. No 
doubt the state of the water is an important factor in the selection of the colors of flies to be used in fishing it, and the appearance of a fly is influenced, not only by the depth, swiftness, and darkness of the water in which it is used, but also by the condition of the atmosphere and the various backgrounds of sky against which it is seen by the fish. Major Traherne and other authorities unite in saying that in a deep and rapid stream a black or red fly will be more likely than any other to attract a salmon's attention. The Jock Scott, though a brilliant fly when seen dry, has a very different and more modest appearance when viewed, floating on the water, from a point below the surface.

The capriciousness of salmon, one of their few characteristics of which we are absolutely certain, makes it unsafe to lay down any but the most general propositions as to what colors or effects in flies are to be used under varying conditions. Perhaps bright or dark colors in strong or high or dark water, e.g. the Durham Ranger, Popham, Silver Doctor, Jock Scott, or Nicholson; for medium and clearing water, the Butcher, Jock Scott, Silver Doctor, and Fairies, brown and black; for low water, Brown Fairy, Jock Scott, 


\section{Tackle}

Silver Doctor. It will be observed that the Jock Scott, Silver Doctor, and Fairies are included in the flies appropriate for all stages of water and varieties of weather, and although I have never done it myself, I think a man provided with an ample stock of different sizes of these three flies could catch as many fish in any river of this country as if he had the entire stock of any fly tier in the world to choose from. Still, few anglers have enough self-control to start forth with so small a variety of flies, and the universal practice is to take very many more than can possibly be needed, which uselessly lumber up the fly book, and ultimately are given away, lost, or become food for moths.

In addition to the Jock Scott, Silver Doctor, and Fairy flies, the Britannia (which is bright and very handsome), the Nepisiguit Gray (which is tied with rat's fur body, light silver tinsel, and mallard wings, and which I have found excellent wherever tried), the Durham Ranger, the Nicholson, or Blue and Brown (claret body, gold tinsel, yellow tail, blue and rich brown hackle mixed, with cocked-up mallard wings), the Butcher, and the Beaufort Moth, or some other white fly, should certainly furnish enough variety for the most 
fastidious angler or salmon. It cannot be denied, however, that there are occasions when salmon will take things they have never seen before, and which are as different from any of the creations of the fly tier as can be imagined.

I took two on the Nepisiguit with a bunch of muskrat fur tied to a bare hook, and, as I have mentioned before, salmon have been taken on the Restigouche with a bunch of red squirrel's fur tied in the same way. 


\section{CHAPTER IV}

CASTING AND WORKING THE FLY

"Who has not seen the Scarus rise,

Decoyed and caught by fraudful flies ?"

IT will be long ere the art of casting for salmon in this country approximates the perfection it has attained many years since in the British Isles. The rivers are so much larger here, on the average, that most of the fishing is done from a boat or canoe, which renders unnecessary the employment of switching, or any of the various underhand casts without a knowledge of which angling would be practically impossible in many of the best rivers of Britain. The time will doubtless come when these things will be studied and learned here; but now, though we have anglers equal to any in overhand casting, I should not know where to look for one posted, practically, in the mysteries of any of the other methods.

The overhand or ordinary cast is made by lifting the line out of water to the end where 
the fly is, and throwing it out behind to its full length before casting it forward. This is the most important part of casting, as, if not done, and there is a slack in the line at the time of the forward cast, the fly is frequently snapped off, and line and fly alight in front in a tangled mass far in direction and distance from where they should. In raising the line from the water, a little jerk should be given just as the fly leaves the surface, which makes it travel up and back much faster than it otherwise would, and prevents the line from hitting the ground or the water on the back cast. It is desirable that the straightened-out line behind should not fall to a lower level than that of the angler's head, and if kept higher than that it is better. The rod on the back cast, to accomplish this, should go as little as may be beyond the perpendicular. To see men casting from a canoe, and not only a good bit of the line, but often the tip of the rod, striking the water behind, is far from a pleasant spectacle. The higher the fly on the back cast, if straight, the less force is required to send it forward, and the knack of getting it into this position or any other whereby the fly is straightened out on the back cast is in applying sufficient sudden force 


\section{Casting and Working the Fly}

as it leaves the water, where there is some resistance to add to the impetus necessary to put it where it is wanted. To use sufficient power in the right place, to get the fly straight out behind, and to know just when to begin the forward motion, the principal force in which is to be exercised at the first part of it, with just sufficient in the remainder of the cast to guide the fly and make it alight properly, can only be learned by practice; which, after a long enough time, enables one to cast far and fine without any consciousness of the methods he employs. In casting for salmon from the bank or from a boat, the line should be thrown across and downstream at an angle of say fifty to sixty degrees. If thrown straight across, the fly does not work so well, and the line remains longer slack than if the cast is made more down-stream. Still, I have seen fish take the fly an instant after it touched the water on the straight-across cast, though such an occurrence is very unusual.

When the fly touches the water, the point of the rod should be held stationary until the fly has swung around one-third or a half of its course; then the rod should be made to follow the fly until the end of the cast, the object being to 
keep the line from bellying, which prevents the fly from working properly, and which also renders a rising fish less likely to hook himself than if there was a comparatively straight line between the end of the rod and the fly. A cast in which the fly reaches the water with a slack line should be at once tried again, as in such instances a belly is created in the line, the fly goes down-stream headforemost for half or more of the cast, and water passed over in that fashion is practically unfished. It should always be borne in mind that the fish should see the fly before he sees the casting line, and, of course, the clearer and shallower the water, the more desirable this is. When the end of the cast is reached, the fly should remain there an instant or more, as salmon will sometimes follow it without rising until it stops, or come at it from the other side. One of the best anglers I know considers the end of the cast the most deadly, and says he hooks more fish by working the fly at that point and gradually letting out and drawing in the line, than in any other portion of the cast. Probably this method attracts fish from a greater distance than it does when the fly passes quickly over. At this point the rod and line are in the most 
favorable position for the next cast, and the line for that purpose may be lengthened out from the reel so much as is desired. Three or four feet additional on the length of each cast is not too much unless in very heavy or dark water, when this amount of new line can be reduced according to the fancy of the angler. In fishing from a boat and casting alternately to each side, one should learn to use either hand uppermost on the rod for either cast, as it is tiresome and annoying to change hands every time the fly is thrown. The fly, of course, is thrown by a somewhat different motion when it has to be cast from the left shoulder with the right hand uppermost on the rod, or from the right shoulder with the left hand above; but a little practice in this enables one to acquire the habit and to add greatly to his ease and comfort in fishing.

In fishing from a bank or wading, while the above general directions will apply in many cases, there are also many where the cast has to be made in quite a different way in order to cover all the water within reach. Of course, if there is plenty of clear space behind, the ordinary overhand cast will do; but if, as is frequently the case, the angler has a backing up of trees or 
high rocks, some other method of getting out the line must be adopted. There are various kinds of these underhand casts, as they are called, the general principle of all being to so apply the force to the rod that the fly, instead of going above and behind the caster, travels low, and near the surface of the water toward the centre of the stream, and then by a sharp forward and outward motion the fly is thrown high in the air, and as it descends straightens out and alights in the chosen spot, never in the course of its travels going behind the angler. It is delightful and astonishing to see how far a line can be thrown by underhand casting, and any angler who has seen a good exhibition of this art will be fired with a desire to attain a practical knowledge of it which I fear cannot be taught from books. Major Traherne says on this subject:-

"Of all the various undercasts the one as practised on the Spey is the most pleasant and satisfactory to make, and, as far as I can judge, a longer line can be got out with it than with any other. It is generally believed this cast can only be accomplished when wading, but if any one knows how to do it, it can be done with quite as great ease and to as great perfection when standing on the bank; but in the latter case it requires a sharp stream to be running evenly close into the bank which is being fished from. ... To make a Spey cast successfully the 


\section{Casting and Working the Fly}

line should be allowed to be carried well down the stream straight and tight to its fullest extent, the point of the rod following the direction of the fly and held very low. Before making the cast the whole line should be lifted clear of the water; if allowed to drag under the surface the cast cannot be made. The Spey fishermen who, I think, are the finest underhand casters in the world, use rods made especially for the purpose. The upper portion, instead of being straight is made in a curve, and, when fishing the curve faces the stream, which gives the rod made in this fashion a greater lifting power than an ordinary one, but I have found I could make as good a cast with the latter."

The proper working of the fly as it goes down and across stream on its journey, for the purpose of producing in it a lifelike movement calculated to impress upon the salmon in the neighborhood the fatal belief that it is no sham, is a vexed question. The popular conviction is that by moving the point of the rod up and down constantly when the fly is in the water, its charms are enhanced. This looks very attractive when it can be seen, on a short cast, but it is certain that on a medium or long cast the up and down motion of the rod is not communicated to the fly at all, and on the short casts the action keeps the fly nearer the surface of the water than is desirable in most rivers, as the rule is to hold the point of the rod low that the fly may sink as deep as possible. I am obliged 
$9^{8}$

to admit that I find myself a good part of the time jerking my fly in fishing, though I am convinced that, even if it does no harm, it does no good. It serves to while away the time and gives one the idea that he is doing something to help along his sport. 


\section{CHAPTER V}

\section{FISHING THE POOL}

"That pleasure which is most comely, most honest, and giveth the most libertie to Divine meditation, and that without all question, is the Art of Angling; which having ever been most hurtlessly necessary, hath beene the sport or recreation of God's Saints, of most holy Fathers, and of many worthy and reverend Devines, both dead and at this moment breathing." "The Pleasures of Princes, or Good Men's Recreations," I6 I4.

WE will now suppose that the angler is at the riverside full of hope and enthusiasm, provided with two to six rods, a commensurate equipment of reels, lines, and casts, and forty to fifty different patterns of flies (for I feel sure that all hints and counsels to moderation and economy in outfit, even when supported by experience, will prevent no one who can afford it from encumbering himself with much unnecessary tackle).

The morning is fresh and balmy with the first breath of northern summer, the birds are carolling their nuptial hymns, the light green of the tender foliage of the hardwood trees is extended well up the mountains, where it merges into the 
darker hues of the spruce and hemlock reaching to the summits, sharply defined against the clear blue sky. The river, recovered from the spring floods, and though still high, is falling, and flows along its course, now through long flats with apparent slowness, now subsiding into ripples as the stream runs over a greater descent or a rockstrewn bottom, now into crested waves which break and foam as they encounter some huge boulder around which they swirl and eddy in angry haste, breaking into gentle ripples, dancing in the sunlight as they reach the pool farther on. Although the "School of Recreation" tells us that "salmon bite best in May, June, and July at three o'clock of the afternoon," and our early belief was that daybreak is the best season for their capture, we take a leisurely breakfast at seven, smoke one pipe, and sally forth to the water at eight, having bestowed much thought as to the size and pattern of the fly we will first show on the pool where no angler has cast one since last year. The river being high but clear, a No. I Jock Scott is chosen, though a friend going to another pool is to try a Silver Doctor of one size smaller. The apocryphal person through whose coming exploits I hope to convey in a pleasing 
manner what may be useful information to some, and the reverse to others, is of course a skilful and experienced angler, absolutely free from prejudice, and tolerant of dissentient views. $\mathrm{He}$ is provided with a fifteen-foot Forrest rod with standing rings, a Farlow tension reel holding sixty yards of Olinea line, having spliced to it seventy-five yards of Cuttyhunk thin bass line, a casting line tested to seven pounds, a book filled with flies of all kinds and sizes, from the veterans with honorable records of former years, and still fit for service, the cripples with parts of their dressing gone, or loops frayed and unsafe, all of which should have been thrown away long since, the dozens of flies never used and probably never to be used, as one or two trials of their kind have been fruitless, to the comparatively small number of pet patterns on which he pins his faith, all tied on turned-down-eyed hooks. These implements are put in the canoe along with a gaff whipped to a light spruce pole seven or eight feet long, a small, round, flat tin box in which repose, between two pieces of wetted thick flannel, a couple of fresh casts, and a sharppointed bodkin, one of the most useful utensils of the angler for taking out knots in a casting line and loosening it from the fly. 
With this equipment he in his bark canoe is poled by two Indians to a pool a mile above the camp, which begins at the end of a heavy rapid, deepening as it slackens around the edge of a projecting ledge of rock, and gradually shoaling with its downward flow until it reaches a comparatively smooth and level bottom, where it glides with almost glassy smoothness, but with a force which has to be felt to be realized. The length of the pool proper is about fifty yards, though it extends or shortens with the rise and fall of the river. In low water the fish lie farther up and even in the heavy rapid, while, when it is high, they are all below the rock, sometimes scattered over the shallow smooth stretch. On this first morning of the season our angler, with the assenting minds of his Indians, had his canoe anchored just opposite the rock a good cast out from shore, and began operations with his Jock Scott, in the hope and expectation of soon seeing the big boiling rise and feeling the "tight line" he had so anxiously been anticipating since the first breezes of spring. Fishing with care and deliberation, and all the time getting on better terms with the rod, he came to the end of his cast, about twenty-five yards, with no sign of a rise. 


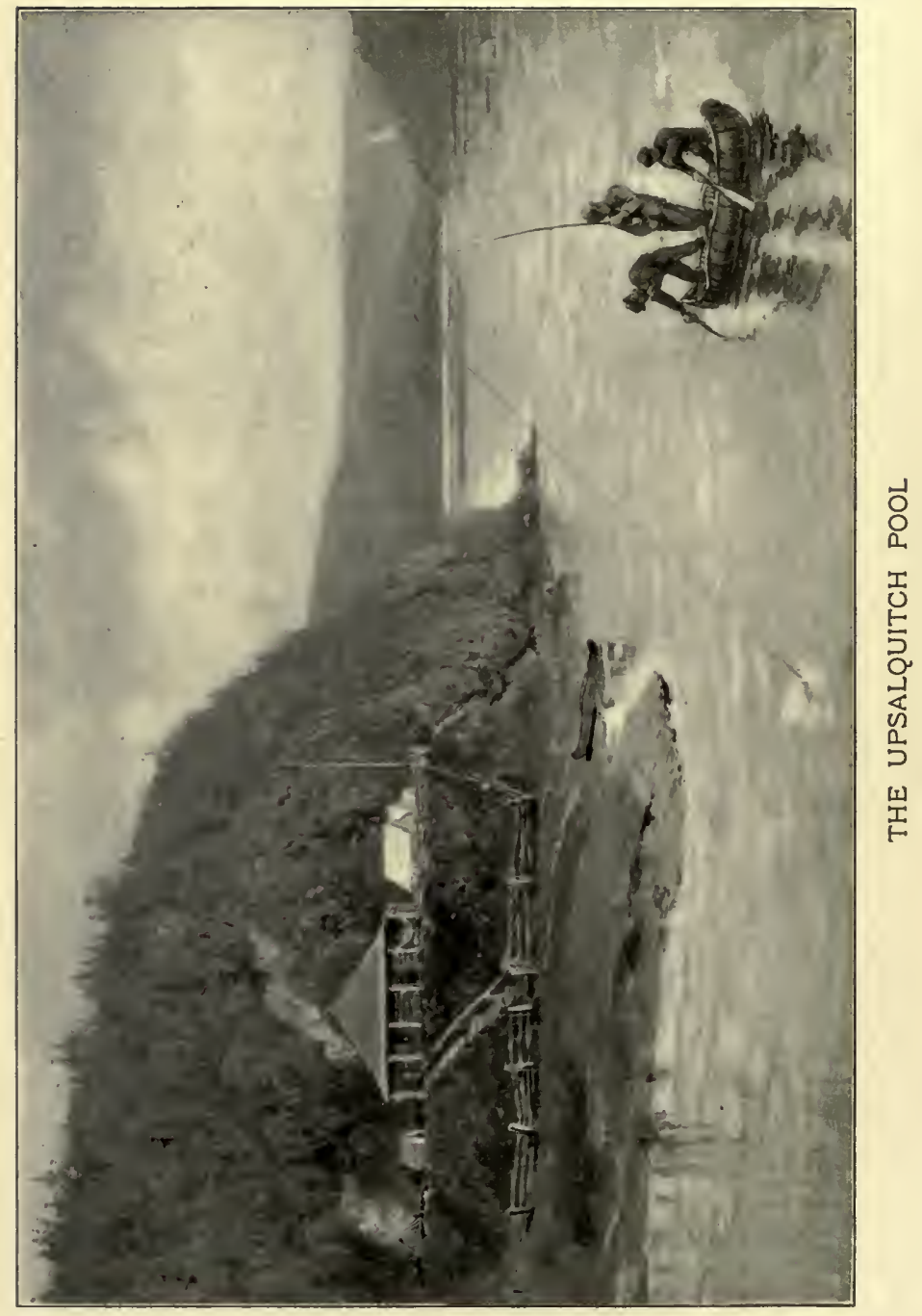




\section{Fisbing the Pool}

Comparatively few fish are killed on casts of over twenty-five yards, and the great majority on considerably shorter ones. I don't think salmon are so likely to rise on a long cast, as the fly is moving more quickly, and there is apt to be a belly in the line which prevents it working so well, and when they do rise they are liable to miss or be slightly hooked.

The canoe being dropped down-stream six or seven yards, fishing was resumed, and through this and the next drop no evidence appeared to justify the belief that a salmon was in the neighborhood. However, the temptation to change the fly was successfully resisted, and at the fourth drop the labors of our angler were rewarded by a noble rise of a big fish well out in midstream, which came with a rush and splash, showing his broad tail as he descended without the fly, nor did he return to it though it was not moved for a few seconds. A man once went salmon fishing for the first time, and after half an hour's work had a tremendous rise. The fish missed the fly, whereupon the angler thanked God and ordered his Indians to put him ashore, nor could he, for the rest of his stay on the river, be persuaded to run the risk of repeating the experience, lest it might 
result in hooking the fish. Neither could our angler resist a transient feeling of relief, as his salmon went down untouched, that the conflict had been postponed. However, he waited five minutes by the watch before casting over the fish again, though this length of delay is greater than many recommend, some saying that three, others two, and still others that half a minute is sufficient. Then, beginning two or three yards above the fish, he cast down till he reached a spot several yards lower, but no move. The Jock Scott was then changed for another a size smaller, and that in its turn for a Silver Doctor No. 3. When these had vainly been shown the salmon, a change was made to a No. 2 Durham Ranger. When this passed over the fish there was a slight and languid break, but that was all to be got out of him, though three other flies, and finally the original Jock Scott, were tried before the canoe was dropped farther down. Fishing was resumed with a No. 2 Jock Scott, and after half an hour's work another rise came, this time on a long cast, and scarcely visible, followed by a strong pull on the line; and as the rod bent a steady pull, not a hard jerk, was given by the angler, the watchful Indian in the stern hastily pulled up the anchor, 
the reel sung, and presently far out on the river a fish of good size leaped high in the air, and then started on his course down and across stream, the canoe being paddled after him as quickly as possible until it got opposite and then ahead of him, where it remained until line enough could be reeled in to make it prudent for the angler to go ashore. Just as he landed the fish sought the bottom, ceased running, and began "jigging," that is, giving hard, short jerks against the line. This is said by some to indicate that a fish is lightly hooked; but be that as it may, this one presently broke his hold, and the angler had the sickening feeling which comes when it is realized that the tie which held the man and the salmon is severed, and that they are parted, probably forever.

Returning to the spot where the fish was hooked, and just below which he had seen a salmon jump while absent, the angler fished carefully down past the end of the pool into the flat below without a rise. Then he went back to the first fish that had come up, and a little below him hooked, on a No. 2 Jock Scott, a smaller salmon, which was landed after a play of about ten minutes and weighed nineteen pounds. Returning to camp, he found that his friend, a com- 


\section{Io6 The Atlantic Salmon}

parative tyro, who had been fishing below, had, soon after beginning, changed his fly to a No. 4 Silver Doctor, with which he had pricked one fish, broken his casting line on another, and landed two of twenty-three and twenty-five pounds. The moral of this tale is to always use rather smaller flies than you think the water requires.

When a fish rises short, it is a good plan to change the fly for one of a size smaller before casting over him again. I think a fish is a little more likely to come a second time if this is done. $\mathrm{He}$ is more on the alert than before he saw a fly at all, and would naturally be apter to notice a smaller object.

The changing of flies is a vexed question and one of the many unsolved problems regarding the salmon. It may be the prevailing opinion among salmon at certain times of their sojourn in fresh water, that a particular size or pattern of fly is worth seizing while they regard all others with silent contempt. Anglers generally assume the existence of this condition on inadequate grounds. A man, for instance, fishes halfway down a pool with a Silver Doctor and stirs nothing. He changes to a Durham Ranger, forthwith hooks a fish, and thereafter firmly believes 


\section{Fisbing the Pool}

that the change accounts for his success. He does not know that the fish would not have taken his Silver Doctor if he had seen it, nor that there were any rising fish in the water he has passed over. A pool may contain a dozen salmon, none of which will rise at anything, or hold but a single occupant, and he ready to take any fly, or a particular one. A hungry fish, like a hungry man, will eat almost anything. If his stomach is full or his appetite is failing, he may be attracted by unusual tidbits, and may even change his mind about one of them when he has looked it over. The only approximately certain way of knowing whether a fish desires a fly of a certain kind, or none, is to fish over him with different varieties of those he doesn't want until you show him the one he does. It is rare in my experience that a fish over which one fly has been cast without result will rise to another shown him very soon after, though I have had two notable instances to the contrary. One morning, late in June, '82, I was fishing the Mowat pool at the upper end of our water in the Restigouche, where the bottom is very level and the stream, though running swiftly, is as smooth as glass. The water was about five feet deep and very clear. I hooked 
a fish soon after beginning, on a Nepisiguit Gray, and when I landed him found that the hook, a Sproat, had, after the custom of its kind, bent considerably. Pounding it back into shape with a stone, I returned to the same place and directly hooked another fish, after landing which I found the hook had straightened again so much that I thought it unsafe for further use. On looking over my book, I found no fly of the same pattern, and so tried four or five others, but no fish would rise to any of them. Then, bending the hook of the gray fly back into shape, I tried that from the same position, and at the first cast hooked a salmon. Him I landed, but the temper of the hook, through frequent bendings, was so nearly gone that, though salmon would rise to it, after pricking a couple, which escaped at their first run by straightening the hook, I took off the gray fly, and tried various others without avail; then, putting it on again, I rose a fish to it at once in the same place I had been casting over. All this was done in so confined a space that there could not be the least doubt of the same fish being cast over with all the different flies used, and that the only one to which they would pay any attention was the gray one. 
Another instance occurred on a piece of water we call the Brook Pool, very similar in character to that mentioned above, where I was fishing one side and a friend the other. I had on a No. 4 Dun Wing fly, with which I hooked a fish almost at once. My friend, who was very near me, both of us casting toward the centre of the river, where the fish were lying, tried several kinds of small flies without hooking a salmon, though he had one or two very faint rises. He would not take a Dun Wing from me until after I had landed three large fish. Then he came over and borrowed one which the salmon began taking at once, and we carried home eight between us. The proof was not quite so absolute as in the case first mentioned, but still convincing as to the tastes of the fish that morning. The theory held by some that salmon are able to distinguish more than the general effect, color, and size in flies, or that they can tell the difference, for instance, between a Silver Doctor and a Dusty Miller, is, I think, untenable. Although it proves nothing as regards any theory of colors, it may not be out of place to give the following statement of the different patterns of flies on which salmon were killed on water I fished in 1896 , and 
the numbers of fish taken by each fly. Total number taken, 353. Of these-

Iо1 were hooked on Silver Doctor and Dusty Miller. 81 were hooked on Jock Scott. 16 were hooked on Black Dose. 18 were hooked on Lady of Merton.

14 were hooked on Durham Ranger.

I6 were hooked on Black Ferry.

21 were hooked on Brown Ferry.

86 were hooked on a dozen other varieties.

It is quite possible we would have killed just as many fish had we been without the first two kinds of flies. Hardly any one is disposed to change a fly the fish are taking, in order that the future angler may be benefited by the experience he thereby gains; and a fly which has become standard like the "Jock Scott" is accepted without question as one proper to use anywhere, which it doubtless is. Some years since, on the Nepisiguit, I was told that the only flies the fish would take were the Nepisiguit Gray and the Nicholson, or Blue and Brown (both previously described). The two friends with me used these flies consistently, but I stuck to the Jock Scott and Silver Doctor long enough to prove that the salmon took them quite as well. Next year I tried the Gray fly 
on the Restigouche, where it and the "Lady of Merton," very nearly the same thing, have been ever since found excellent. I fished the Galway River in Ireland one April, and landed the first fish of the season taken with the fly on one I tied in Nicholas Brown's cottage, and from his materials, a rough and simple combination of claret body, gold tinsel, brown hackle, and wild turkey wings. It was so radically different from the gaudy flies in general use on the Galway that Nicholas advised me to "hould to the shrimp," but I got a twenty pounder with it on the "resarve" inside of half an hour. A salmon is quite as likely as a human being to change what answers to his mind, and while at three P.M., of ten fish lying in a pool, one may be disposed to rise, an hour later the tendency may have left that one and taken possession of part or all of his fellows. It is a fact that usually but a small proportion of salmon will rise at any given time, and they may come up freely in one pool, whilst at another an hundred yards distant, where they are quite as plentiful, nothing will tempt them. Many salmon start for a fly floating near the surface, and abandon the chase before a break indicates their presence. I have often seen fish make a rush for a fly, stop short, and go back 
to their seats without the angler being conscious that he has attracted them. Probably fish doing so will not rise again without being rested, which of course cannot be done in default of information the angler is not likely to have.

Once I saw below me, from the high Metapedia Railway bridge, seven salmon lying almost motionless in the swift clear water. A friend was fishing above in the pool, and I told him to come and cast over them that I might observe the result. None of them stirred the first time the fly passed, but one started for it on the second or third cast, and turned when within a foot of the surface. Waiting a few moments, my friend began again, with no effect on the fish. The fly was changed, and as soon as it was seen another fish darted at it when it was at least five yards one side of him, turning away just about as the other did without breaking water. A rest was given this fish, but he would not come again; then the fly was changed, when a third salmon came halfway to the top, and that was the end of it.

I once fished the same place from the upper end of one of the high piers on the up-stream side of the bridge. There I saw one fish start from the bottom as my fly passed over him, and 


\section{Fisbing the Pool}

go back without quite reaching it or moving the surface of the water. A rest and change of flies availed nothing with this fish, but after a time, as the fly was very near where he had come from, I noticed a portly form emerging from the obscure depths farther under the bridge. He came on with a deliberate dignity fitting to his bulk, opened his mouth as he approached the fly, slowly closed his jaws on it, and quietly started with it back toward his residence. Though I gave him a good pull at once, he continued his deliberate progress until out of sight, a couple of yards perhaps, and then realizing he was in trouble, quickly threw off his air of leisurely superiority. A long struggle ensued, during which I succeeded in getting my rod with a somewhat disabled reel under the bridge to the lower side, where the salmon had gone. He was lost when thoroughly exhausted, by the idiotic conduct of an angler in a canoe, to whom I offered the fish if he would gaff him, and who tried, despite my entreaties, to haul him up-stream by the line, until the weakened hold gave way, and fish and angler went safely down-stream, leaving me securely perched on the bridge, lamenting what I still consider the great calamity of my fishing career. 


\section{CHAPTER VI}

\section{STRIKING, PLAYING, AND LANDING}

"Not gladder Shobden's wealthy peer

Views his fat oxen and his deer,

Nor peeress, when her alms she gives,

Nor those her charity relieves -

Nor Gripus, as he scans his store,

And counts and counts it o'er and o'er,

Nor Stella, decked in nuptial pride

And just about to be a Bride -

Than I to feel, O bliss Divine !

A Salmon floundering on my line." - Old Song.

THE advisability of striking a salmon at all is largely a matter of the water in which he is caught. When I first fished for salmon, after a long apprenticeship at trout, I could not for a couple of days resist the impulse to strike as soon as the rise came. The water was heavy, as were the fish, and the result was that I snapped off three or four flies before I learned to command myself. The great force of the current, added to the weight and motion of the fish, not only made the salmon certain to hook themselves without any 


\section{Striking, Playing, and Landing}

effort of mine, but caused the effect of striking, on the tackle, to be about the same as if it had been fastened to a twenty-five-pound iron weight.

Some years later I fished the Nepisiguit, a much smaller and shallower river, which, in many of its pools, has hardly enough current to keep the fly straightened in its journey down-stream, and it had to be worked very much as in fishing for trout. In such places the salmon rose to the fiy on the surface, and if they were not struck the instant the rise came, just as in fishing for trout, the greater part of them were not hooked, as they probably quickly discovered the deceit and ejected the fly. I have never fished any other river where I did not consider striking unnecessary. When a salmon takes the fly and goes down with it, the rod should be held steadily in its position, and the weight of the fish is sure to force the barb into him as he descends. When it is certain, from the strain, that the salmon is hooked, a steady pull during the instant that generally passes before he begins his run may fix the barb in his jaw as firmly as the first few yards of the impending run will do. Besides the danger to tackle from striking when the rise is seen, there is another serious one of snatching the fly 
away from a fish that has not yet taken it but is about to do so. Even when it is certain a salmon has missed a fly, he will frequently turn and take it if it is left where it was. Some advise casting at once in the same spot before the salmon has time to settle, but leaving the fly is better.

While most would say that the rise followed by the first rush of a salmon after the instant of suspense, yields the supreme delight of angling, the ensuing moments of contest, full of anxiety as they are, may furnish the most enduring recollections. One of the maxims of salmon angling is, when your fish is hooked, to get him ashore as soon as possible, regarding of course the safety of your tackle. If a salmon is lightly hooked, he will escape anyway, and it is better for him, and for the angler, that he should do so soon than after a half-hour of ladylike dallying with him. After a salmon is hooked it is wise to reverse the rule of doing all you can to please him, and instead, to assume an attitude of determined opposition to every move he may make. Wherever it is possible the angler should try to get below his fish as soon as it can be done after he is hooked. The tendency of the salmon is to keep his head up-stream, and he is fighting the rod and 
the current together if the angler is below him, whereas if the angler is above, it is he who has to overcome the force of the stream in addition to that of the fish. Of course it may, for various causes, often be impossible for the angler to go down with a fish a quarter or a half mile, but where it can be done it will be found to materially shorten the time of bringing him to gaff, and every unnecessary moment spent increases more and more the chances of loss. The necessity of keeping a continuous strain on a salmon has been realized by every angler. This fish has the power, common to many of his species, of ejecting forcibly from his mouth things he doesn't approve of, and doubtless can do so with a fly unless it is firmly fixed, when the line is slackened. I have seen a shrimp bait forced several inches up a link of gut above the hook by salmon in the Galway, and have no doubt the same methods are adopted, and often successfully, with flies. The strain on the fish is unavoidably broken in two instances, - first, when he turns and runs toward the angler. All the latter can do in such a case is to run back himself, if he can, and reel up his line as fast as possible. Both of these means only suffice to shorten the danger period. 
Second, when the salmon jumps, and this is almost invariably done after a quick turn upstream, which leaves a belly in the line, and the salmon, in jumping, has to pull all this through the water and against the current, making it liable to part in any weak spot, especially when the fish leaves the water. At the instant he does so the point of the rod should be lowered to ease the additional sudden strain, and as soon as his leap is over the rod should be lifted and the strain resumed. Frequently salmon are lost in these jumps in spite of the angler, as he may think the fish is running down and across stream, and suddenly sees him in the air fifty or seventyfive yards above where he thought him to be. The object, then, is to get the great loop out of the line as soon as possible and thus relieve it from the heavy pressure of the current. This is done by going as nearly as may be directly below the fish, thus straightening out the dangerous loop in the line. In cases of this kind a thick, heavy line is at a great disadvantage as compared with a light thin one, which offers so much less resistance to the currents, and the Cuttyhunk bass line spliced to the other will often result in saving a fish, nor is such a line so likely to sink 
to the bottom, where it may become entangled or broken among sharp rocks, as a heavy one. The risk of letting up on the strain is often made manifest by the hook dropping out of the mouth when the fish is gaffed and the line slackened. Unless the hook is deeply embedded in the tissues or is close to some of the bones of the head, it is apt to work loose in the course of a protracted struggle, which often brings about changes in its position and in the direction of the pull against it, and while it may hold if kept taut, an instant's let-up will enable the fish to eject it. It should always be borne in mind that the longer the fish remains in the water the more the chances of getting him out of it are lessening, that wherever practicable as heavy a strain should be put on him as is regarded safe for the tackle, and that it is correct to assume every movement of the fish to be hostile to the interests of the angler and therefore to be opposed on principle. It is a good idea, when it can be done, to get a salmon into a still pool or eddy when he begins to show signs of relenting. $\mathrm{He}$ is quite likely to relax his efforts to escape when coaxed out of the current, and I know several places of this kind in different rivers which, when reached by salmon, hooked 
above, they hate to leave, and generally remain there until gaffed. When a salmon is sufficiently tired out to be gaffed, the gaffer should go below him, entering the water far enough below the fish not to scare him, and remain there in a stooping position with his gaff outstretched, and perfectly still, until the fish is brought inside the reach of the gaff by the angler, when it is to be gently lowered beyond the shoulder of the fish and quickly pulled inward. Striking at the fish with the gaff is not to be permitted, or moving toward him as he is coming down-stream. In case the fish takes alarm or is evidently not coming within reach of the gaff from where the gaffer is standing, he should come out of the water and enter it again farther below, and never attempt to gaff the fish until he is sure of him, for a salmon frequently regains a good share of his pristine vigor from being wounded by a gaff or even vainly struck at by one. He will much more readily be brought up to shore where the water is of moderate depth than where it is very shallow, and, as I mentioned above, where the current is not rapid.

In gaffing from a boat, it should be below the fish, the angler facing up-stream and well back in the boat, and the gaffer ahead of him in the bow. 


\section{Striking, Playing, and Landing}

So soon as a fish is brought ashore he should be despatched by a knock on the head with a club or, that lacking, a stone, the fly removed from the jaw, flicked in the water two or three times to cleanse it, and then the tackle examined and line and casting line tested to see if everything is sound and uninjured by the recent struggle. This is a very important matter to be attended to, and many a fish is lost by neglecting it. Salmon, even of large size, may be landed by dragging them gently up on a shelving beach without the use of a gaff, and it is interesting to see how much less force is required to effect this than one who has not seen it done would suppose. The stones, as well as the salmon, are slippery, and when once started the fish seems to help himself along and to slide ashore. The most successful angler I ever knew was a settler on the Restigouche, now departed, named Alford. He had a little piece of water in front of his place and adjoining some in which I was interested. This he fished very slowly and daily from a canoe alone, going over it probably six or eight times between sunrise and dark. If he rose a fish, he would keep at him for hours, and in the end generally hooked him. I think he caught more salmon than any man on 
the river every season, in his own water and that of others, who did not always know when he was there. When Alford hooked a salmon he would throw overboard a buoy attached to his anchor, stand up in his canoe, rod in one hand, and in the other a pole with which he pushed the canoe toward shore until he reached shoal water, where he stepped out, pulled up the canoe so it would not drift off, and began attending to his salmon, which in the meantime had generally taken out a lot of line. Alford always beached his fish, as he never had any one with him, and landed very many large ones in this manner, one which I saw weighed being forty-five pounds.

The length of time required to land a salmon depends on several things, and not always on his size, as salmon vary quite as much as men or other animals in power and endurance. The various works on salmon angling contain accounts of many thrilling encounters with enormous salmon. One of these, recounted by Couch, in "Fishes of the British Islands," as having taken place on the river Shannon and "from an Irish source," is worth narrating. The man who hooked the fish played him for five hours, during which he was worked three miles down-stream. In the approaching 


\section{Striking, Playing, and Landing}

darkness this angler became faint from fatigue, and a companion took the rod. He fared little better, though he kept up the fight for eight hours, finding himself at the end of that time seven miles farther down the river, and day just breaking with the fish as fresh as a daisy. The news having by then reached a gentleman living near, he hastily arose, proceeded to the field of action, where he gave the exhausted angler a pound bank-note for the rod and chance of success. For four miles farther and nine successive hours the struggle lasted with the third combatant, until with a desperate plunge the fish broke off the rod close to the reel and proceeded to the sea, leaving with his last adversary only the reel and part of the butt. The time occupied was twenty-two hours, and the distance travelled down-stream was fourteen miles — the book says "almost twenty miles."

The fish may have been a relative of the one Nicholas Brown of Galway used to mention, which was hooked late one afternoon by the "Portumna Man," who played him for three hours, when he sent home for his supper, which he ate while the fish was sulking, then worked hard at him till early morning and took advantage of another sulking time to write an account of the conflict for the 
morning paper. After this literary diversion he stirred up the salmon again, and succeeded in landing him at breakfast time - weight fourteen pounds.

The largest salmon I have ever known to be taken with a fly, was killed by Mr. Dun on the Cascapedia some years since, and weighed fiftyfour pounds. A farmer on the Restigouche, Sandy Macdonald, told me he took one in a drift net on that river early in the eighties, weighing sixty-five pounds, which is perhaps heavier than any of those which I and other anglers have played and lost. Both of these were male fish, "kippers" they are called in Britain, - though according to Badham in "Prose Halieutics," p. $3^{1} 3$, " a kipper is a salmon previously well scoured and cleaned that has received several dry rubbings of pepper and salt, and afterward been dried either in the sun or else in the smoke of peat and juniper berries."

If a salmon of twenty pounds or above had intelligence equal to his strength, he could not be held for two minutes by any tackle in ordinary use. Most anglers have had the opportunity of realizing their own powerlessness against such a fish in case, as two have done with me, 


\section{Striking, Playing, and Landing}

he starts straight down-stream for the sea until he has emptied the reel, when something has to go, or if he takes a big run down and then comes up suddenly and jumps, when the strain on the belly of the line is almost sure to be fatal. I have often heard that a salmon hooked pretty well down in the tongue will not make a long fight, probably from his mouth being kept open more than if the hook is fast in the outer bone of the jaw. Foul-hooked salmon are always very stubborn unless hooked in the tail, when they tire after a few rushes, as the pull against their principal means of propulsion is very trying. A salmon hooked outside, under the chin or anywhere about the head, if big and strong, may keep the angler occupied for hours. A friend of mine landed a twenty-five pounder in the Jupiter River on Anticosti Island, hooked outside the jaw, which resisted his best endeavors for five hours; and I once had an exciting struggle with one for two hours, half the time it being pitch dark, which took me nearly two miles downstream and kept me very busy until he was gaffed. I suspected he was foul hooked, as he turned out to be, under the pectoral fin, but nevertheless would have firmly believed, had I 
lost him, that he weighed at least forty-five pounds. He did weigh thirty-two pounds, and was a male fish, of which sex, on all rivers I have ever fished, I have taken but a small proportion, and those have averaged far superior in fighting powers to the females. Altogether the strongest and most determined salmon I have ever taken were two males of thirty-four and twenty-eight pounds, the latter being the better one, and each taking an hour to kill. When I had the big one pretty tired I succeeded in getting him into a deepish pool near the shore, where I could plainly see him from the bank, and several times I noticed him almost perpendicular in the water amongst the stones on the bottom, trying to rub out the hook.

Sir Herbert Maxwell in "Salmon and Sea Trout" says: "In perfectly clear water it may be seen that a sulking fish assumes an almost vertical position with his head down," and that "to move him from this posture of resistance and cause him to move about, an attempt should be made to get a side pull at him." I am not sure that this "vertical position" is always assumed by sulking salmon.

The two largest salmon I ever saw taken, 


\section{Striking, Playing, and Landing}

forty-one and thirty-nine pounds, were landed in twenty and eight minutes respectively, and the latter one never ran out twenty yards of line. I should say that fifteen to twenty minutes was plenty of time to land salmon averaging twenty pounds, fairly hooked, and it must be an extraordinarily strong and stubborn fish that cannot be brought to gaff in half an hour. There are many anglers who take delight in protracting the struggle as long as they can, and will hold down their rods when a fish is hardly able to move, in order to encourage him to try to make one more run, like a cat with a moribund mouse, and this they call sport. Fortunately such anglers generally loose a good proportion of the salmon they hook.

Here I wish to quote from a letter written me by Andrew Williamson, a well-known Scottish sportsman and author, equally skilful with rod and rifle, and who has killed salmon, and many of them, in both hemispheres:-

"Why do salmon in Canada and Norway give so much finer sport than those in Scotland? So much so that for my part I would rather kill one there than five in my own country? In the latter, the heavier the fish the more sluggish he is. In the former I have found it just the reverse. In the Annan, on 
my return from Canada I killed three fish, thirty, twenty-four, and eighteen pounds, not one of which went twenty yards, or once showed himself. As for any sport they gave, I would as soon have been fast to a log. The Dee and the Spey fish play better. I had once great sport with a thirty pounder on the Dee hooked in the back fin, but the Tweed fish rarely show any sport. I have heard it said that our fish are dull because they come up in the Autumn, but on the Ligne in Ross-shire they run in May. In that river I killed several large fish, one of them thirty-eight pounds, which I saw enter the pool nearest to the sea but a few minutes before I hooked him. He fought but little and I had him out in twenty minutes. My keeper on the Dee, the year before he entered my service, landed on the fishing below mine a fresh-run salmon of fifty-seven pounds in fifteen minutes. It was all so easy he described it as 'quite frivolous like.' My belief is that the explanation is to be found in the exhilarating character of the Canadian and Norwegian climates which, unlike ours, are not subject to sudden atmospheric changes, to which fish and animals are so keenly alive, and that the best of our fishing is had after the nets are taken off in September, when the salmon are in more or less a gravid state."

This is a question on which it would be interesting to have the opinions of a number of anglers who have fished here and in Britain. My own experience has been small on the other side and confined to the Galway, where I had excellent sport the first half of April, twenty years since, and lately to two small rivers, the Kerry 
and Badachro, on a shooting in Ross-shire, Scotland. In Galway it did not strike me that there was any difference in the play of the fish from those in Canada; but the three small salmon I took in the rivers of Ross, the biggest being only seven and a half pounds, were as sluggish brutes as I ever saw, all making for the bank at my feet as soon as hooked and burrowing there until they were gaffed. Their conduct was so disgraceful that I could hardly believe the first one was a salmon, and a sea trout of two pounds I took in the Badachro gave more sport than the three of them together. 


\section{CHAPTER VII}

HOURS FOR ANGLING, AND MISCELLANEOUS ADVICE AND EXPERIENCES

"Who woll vse the game of anglynge must and ryse erly."

- Jvlyans Barns, "Boke of St. Albans," 1486.

IT is perhaps unkind as well as ungrateful to the reverend and illustrious mother of angling to attempt to controvert such an unqualified statement as the one of hers which heads this chapter. Her views on the subject of early rising for anglers prevailed for centuries, though a few audacious writers ventured to differ from her; but their influence on public thought was trifling, and for centuries the majority of anglers groaned beneath the yoke of this, as well as other, mediæval nostrums. H. R., in "The School of Recreation," I684, says, "Salmon bite best in May, June, and July, at three o'clock in the afternoon." This was a feeble, disconnected, and rather vague statement. Thomas Fairfax, in "The Complete Sportsman," about I760, tells us "His [the salmon's] best biting time is at nine in the forenoon and three in 


\section{Hours for Angling}

the afternoon in clear water." Both of these were preceded by the "Innocent Epicure," I697, which recommends a different hour, but still not an early one, as follows : -

"At Midday when the Sun exerts his Rays See on the Surface how the Wanton Plays.

Then wisely tempt him \& from Force or Choice You'll see him nimbly to your Pastime Rise.

Strong be your Lines, your Hooks, your Rods \& all, And wise your Conduct, or he breaks the whole."

With the general growth of intelligence there has been a gradual change in public sentiment as to salmon fishing, as well as in other respects, and the modern tendency is perhaps to disregard any fashions in morals, manners, and sport simply because they are old. Many, who are not young, cannot agree with these prevailing ideas of the day, but cling more or less fondly to ancient superstitions. These unenlightened persons have, by their pernicious example and advice, convinced certain of the younger generation, though not many of these have the time or money to go salmon fishing, that about daybreak is the most auspicious time to begin operations. Wherefore many an ambitious tyro, possessed with this heresy, still sallies forth, with some of his elders, 
through the dripping grass and penetrating fogs of the early June morning, often finding his pool covered with mist, and passing a comfortless and luckless season, until it is time for the fish to rise, when he returns to his breakfast with nothing to repay him for his sufferings except the consciousness of having performed a repulsive duty.

During the years I was addicted to this practice I never had but one really good early morning's sport, and that was on the first of July at a pool in the Metapedia. Old Joe Bernard, who was my head Indian, waked me at daybreak and refuted my arguments in favor of further repose by repeating, "Beautiful mornin' fer de salmon," until I yielded and went to the canoe. The weather was warm, clear, and bright when the sun rose, and in two hours I came in to breakfast with four salmon averaging twentyfive pounds each. For years afterward the memory of this exploit cost me many a broken night's rest and many a shivering barren morning. When the water is low and the weather hot late in the season, early morning may be better than after the sun gets high, but at all other times I think eight o'clock is quite early enough to begin. The two best days' fishing 


\section{Hours for Angling}

I have ever had I took all the fish, eight each day, between twelve and two P.M. Both were bright, warm days, and the water was at a moderate pitch and clear. Major Traherne, in the Badminton Library, says, "The time of day when I have found salmon take best is between the hours of nine A.M. and one P.M., and from four to dusk in the evening."

In the first of the season, when the water is cold and high, any time of day except the early morning is good, and the brighter and warmer the better; but, take it all around, I would rather have from four P.M. until dark than all the rest of the day; and from early in July there are some excellent, smooth, but good flowing pools that, without a good breeze, could not be fished successfully until the beginning of twilight, from then till dark being the best. The fish in these places, which earlier will occasionally make a languid rise to a No. 6 or 8 or smaller dark fly, as the obscurity grows in the evening will come vigorously at big flies $\mathrm{I}^{\circ}$ and $2^{\circ}$ or larger, the sight of which would make them flee from their resting-places in the daytime.

It is impossible to lay down anything more than a very general rule as to the best days or 
times to fish. Salmon will frequently refuse to rise or suddenly cease rising when "all in nature pleases," or reverse the processes at times when man is not "vile" and the conditions are apparently most unfavorable. Therefore the angler who, undiscouraged, hopeful and careful, has his fly the most hours on the water, is sure to rise the most fish.

For years I credited the current belief where I fished that salmon would not rise when it thundered. One day I was caught in a sudden shower and thoroughly drenched, but, having seen two fish jump below me, I decided to give them a trial, the result being that notwithstanding the storm continued in a most violent fashion, with heavy thunder at short intervals, for two hours, I hooked five fish, of which I landed three.

Another archaic belief which has been greatly weakened is that salmon will never take when there is mist on the water. Two years since a friend of mine came down the river from where he had some water fifteen miles above, and said that he had killed five fish the preceding afternoon in a heavy mist so thick he could not see his fly ten yards from the canoe. We had the same mist where I was fishing, and when 
it began I went to camp. Very shortly thereafter I heard of two instances of capital sport, one in Canada, and one on the Dee in Scotland, in dense fogs. So there is hardly one, if any, rule in salmon fishing without exceptions. Mr. Samuel Wilmot of Ottawa, a veteran and successful angler, held the belief that salmon slept during the heat of the day and that their normal periods of activity were mornings and evenings. To prove this he had several salmon confined in a pool he made near the mouth of Indian House Brook on the Restigouche, and said that at midday, especially in warm weather, they were almost torpid, and had to be disturbed a great deal to rouse them to any kind of activity. This view of Mr. Wilmot's has lately been confirmed in a letter to me from Mr. Andrew Williamson, and I think what he says is interesting enough to be given here:-

"Do salmon sleep? I am convinced they do and that this often accounts for their not taking. One calm, cloudless day on the Grimersta, the last of the season, I fished, without getting a rise, the tail of the second loch where just as the waters enter the river there is a hole which usually holds a good lot of fish. I told my gillie to row me to the other side, a distance of about thirty yards. As he did so my black pointer swam after us, and was carried by the stream right over the place 
where the fish lay. No use, apparently, in trying that pool! I had scarcely spoken when a fish rose, and I instantly threw over him. He came at once, and in less than an hour I killed five, all hooked within a yard or two of the very place through which the pointer had been carried. Apparently he had roused them from their siesta.

"A Mr. S. who had some water on the Dee was convinced that his neighbor, Mr. B., habitually sent his keeper to fish the only one or two good pools he had opposite. Arriving one morning at one of these, under a bridge he found Mr. B.'s keeper, as usual, hard at work, but who had then seen nothing. S. in a rage threw several large stones into the pool, and his feelings may be imagined when he shortly thereafter saw the keeper land two large salmon. A friend of mine was once fishing a small Aberdeenshire River on a bright, sultry day with no result, when he was accosted by a pearl fisher with the remark, "You will no get a fish the day if ye dinna let me wade through that pool ; the salmon are a' fast asleep.' My friend, for the fun of the thing, consented, and shortly thereafter landed three fish."

Rising salmon will not always take a fly coming directly over them, as there are certain resting-places from which salmon are in the habit of going several yards for the fly, and if it is not presented at that place they will disregard it. A very notable instance of this is at the Flat Rock Pool at Pabineau Falls on the Nepisiguit. The fish lie in numbers in a deep 
pool, just above which is a very swift, glassy, and shallow rapid flowing into it over smooth rock. The salmon will not rise in the deep water where they stay; but the fly has to be cast at the top of the rapid, down which it goes so swiftly that it seems impossible a salmon could get it, but it is taken by the fish coming up from the pool and always before it reaches there. Another place I know where a. gradually shelving rock goes down into the river. The fish lie six or eight yards from the shore, but take the fly close by the rock and will not rise elsewhere. I recollect once hooking a big fish very near the rock in low water. I saw him coming for some distance, and as he drew near the fly he turned on his side before seizing it. I had seen this done before when I had happened to be over fish in clear, shallow water, and incorrectly assumed that this turning was habitual with salmon; as I have since had the chance of seeing them take a fly as one naturally supposes they would. Salmon often lie on the comparatively smooth beds of river flats, where there is no shelter in the way of big rocks or bars. In such places, and indeed in others with rougher bottoms, the fish are liable to 
change their seats from time to time. In a deepish pool containing big rocks or ledges, one familiar with it can tell pretty nearly just where the fish are to be found, and there are many such wherein one boulder on the bottom is sure to have a salmon behind it if any is in the pool. To such favorite retreats fish at once return if they have risen at a fly and missed it. But in the cases of fish rising in the pools where the bottom is smooth, they may come from quite a distance at the fly, follow it for several yards before showing, and then not return to the places where they were lying when they saw the fly. In a pool of this kind, when fished from a canoe, in dropping down a fish may be disturbed, and go downstream or to one side. As things grow quiet this fish is likely to work back to his first resting-place, and it is not at all a rare thing to see salmon return to positions quite near the canoe after it has been motionless for some time. These fish may not have been cast over at all, or if so when they were alarmed and moving about, and I think it is from such that the greatest number of those come which follow and rise at the fly as it is being reeled in when 



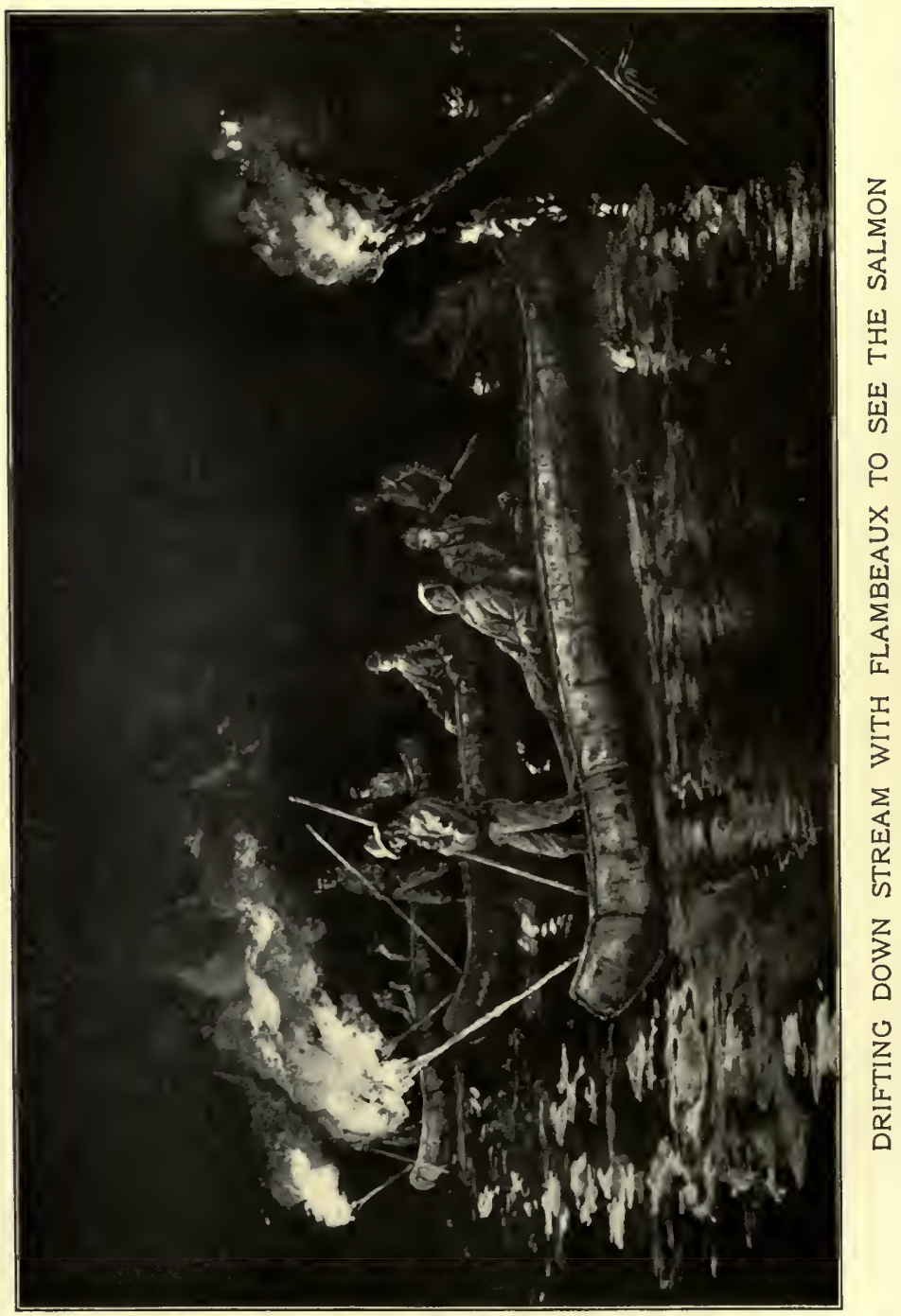


the cast is finished. Why these fish so seldom take the fly, though they sometimes do, it is hard to tell, unless they become alarmed as they approach it by reason of its unusual and more violent motion and its nearness to the surface. Indeed, most of these rises are made near the canoe when the fly is on the surface and moving rather rapidly. As they are generally unexpected by the angler, he cannot quickly enough stop the motion of the fly. The rare cases in which I have hooked fish thus rising have been those in which I had enough presence of mind to stop reeling at the first sign of a rise, and even let out a yard or so of line in order to sink the fly a little and allow it to drop down-stream. By so doing I have induced a salmon to make another dash at the fly and get it. Salmon rising in this way and missing can very seldom be made to come again after resting them.

When a salmon rises at a fly and misses it in a pool with a level bottom, it is impossible to know just where he started from or where he will settle after he goes down. Consequently the angler, after resting him, should begin fishing with the same fly, or one a size smaller, and this latter is advisable in case the rise was not a strong one, 
at a point somewhat above that of the rise, and continue six or eight casts below. The salmon is more likely to be below the place where he showed than above and farther to the right or left, but nothing certain can be known as to his whereabouts. After a salmon has once risen and refused to come again to the same fly or to one a little smaller, it is considered best by many high authorities to leave him to his own devices for half an hour or longer before trying him again. My best results have been obtained by sticking to the fish until he stops rising at anything, and frequently he may come at a fly after he has been indifferent to the three or four preceding ones. Sometimes a fish will come to a fly presented to him from a different direction to the one he has refused. I once rose a fish three times from a canoe within casting distance of the shore, and after that cast over him ineffectively for twenty minutes. Then I went ashore, and as soon as the fly reached him coming from the other way he took it. After.a salmon has risen two or three times without hooking to the flies in common use, his normal tendencies are abandoned; and he is just as likely to come to a fly that would inspire him with 


\section{Hours for Angling}

terror were it the first one offered him, as to any other. He may have risen to a No. 8 Fairy, and after declining intermediate sizes and colors, come with a rush at a No. I Britannia or something else equally as large and brilliant. I have risen salmon as often as eight or nine times and at last hooked them. As an instance of the freaks in which they indulge I give this experience of a friend. He rose a salmon which missed the fly, rested him for five minutes, then cast over him when he again rose and missed, and as the fly went on three or four yards below another fish rose at it and missed. A rest of about three minutes, and then as the fly came midway between the places of these two rises both fishes rose simultaneously and missed. Mr. L., after three minutes more, rose fish No. 2 again, then waited the same length of time, and cast over the spot (the fifth time), when again both fish arose. A minute's rest and another cast brought up fish No. 2, then after an interval of half a minute the fly started down again, and was taken by fish No. I, which broke loose after being on for ten minutes. Then Mr. L. returned to the same place, and on the second cast hooked and killed fish No. 2, weighing 
twenty-five and a half pounds. The first rise of all was on a Butcher. After the third rise the fly was changed to a Silver Gray, after the fifth back to the original Butcher.

Fish which are pricked will not generally rise for some time after, but this rule also has exceptions. I once hooked a salmon which escaped by the loop of the fly coming away, and while fishing down the same pool half an hour after, I saw a fish jump about where I hooked this one. Returning to the spot, a salmon took the fly, and on landing him I found my Silver Doctor, minus its loop, firmly stuck in his jaw.

I have amongst my angling memorabilia three flies found in the mouth of salmon I have killed. Two of these are attached to casting lines about six feet long, and one has, besides a three-yard cast, half that length of line to which it is fastened.

It seems strange that a salmon should be inclined to rise after having been gaffed the day before, as I have mentioned, or even with a hook in his jaw, and trailing ten or fifteen feet of line after him. Fish wounded by the nets through which they have lately passed are known to be more likely to take the fly than their unscathed companions, and the same is true of those which 


\section{Hours for Angling}

have been bitten, and sometimes badly, by their marine enemies. My Scottish correspondent, before quoted, tells of an old Kelt which had become imprisoned by the falling of the water in a small but deep pool: "Over this fish, for lack of other sport, some members of our party amused themselves by throwing a fly, and though he was landed as often as three or four times a day, he was quite ready to seize it as frequently as offered. In the Grimersta River, of which I have spoken, the worm was such a deadly bait that some of the anglers agreed not to use it, and a gentleman once fishing there landed with this bait in one hour and a half seven fish, the worm being greedily seized the instant it was in the water. While some of the fish were fresh-run, others by their dark appearance showed they had been away from the sea for some time." I do not know any instances in this country of salmon being taken with bait nor even of it having been tried, though I have no doubt its use would prove successful.

An English gentleman killed quite a number of salmon some years since at Chain of Rocks on the Restigouche, with a small brass spoon, which he gave when he left to one of his Indians, who showed it to me. 
The best stages of water for fishing are just after a rise begins and after a rise, when the water is at the turn and commences falling. When a river is growing in flood or when it is low and falling, salmon are generally, though not always, indisposed to rise. It has been said that there is one hour or more out of every twenty-four when any salmon in any pool will take a fly, which at the least it would be hard to disprove. When salmon have been for some time settled in a pool, often fished over and perhaps pricked, they learn to associate the sight of a man, a canoe, or even a rod and fly, with danger. I have seen three or four salmon, in low, clear water, drop down-stream and out of sight when a fly floated over them, and in the same spot presumably the same fish would take a fly at dusk when the line was not so clearly visible. A rise of water will send many of these fish up-stream to new scenes, where they are much less shy and have to learn anew the lesson of caution, as do their relatives from below who come up to take their places. It is certain that fish are much more likely to rise for a short time after they reach a pool than when they have been there for several days. On their arrival from the 


\section{Hours for Angling}

sea, where they have remained for periods varying from six months to perhaps three years, they are comparatively unsuspicious of novel dangers, and do not curb their rising tendencies nearly so much as after a sojourn in fresh water. In the majority of rivers on this side, contrary to the general rule in Britain, the first run of fish is composed of large females which go directly through to the upper waters very soon after the ice leaves, generally by the iniddle of May, don't stop in the lower pools at all, and will very rarely take the fly until they are well up the rivers. This run is followed ten days or three weeks later by another of rather smaller fish, with a considerable proportion of big ones, which make a more leisurely progress, and take the fly at favorable times and places. The succeeding runs are made up almost entirely of smaller fish, presumably the grilse of the year before.

In many of the Canadian rivers the best season for angling is coincident with that of $\log$ driving, and the disposition of the salmon to rise is not at all diminished by the river being well covered with floating logs. They will take a fly close beside a log going down the rapid current quite as freely as if the river were clear; and 
while many so hooked break the tackle by running under the logs, it is surprising how large a proportion is landed in spite of the great risk. The best course to follow is for the angler, if fishing from a canoe, to get ashore, if he can, and keep the canoe above the fish to turn aside such logs as threaten to come near the line.

I was once going back to camp just at dusk, after a fruitless afternoon, when I saw a good fish jump in a small, quick-running pool known as "The Judge's." The logs were very thick indeed, but Jacques, my Indian, insisted on anchoring for a trial at the salmon. There seemed hardly room to cast, and the man in the stern had to keep a sharp lookout to shove aside the logs that might otherwise run into and swamp us. Waiting awhile for a clear space where we had seen the fish, I cast over him, and he took the fly at once, and in spite of me ran under a floating log before the anchor could be lifted, and went off with a yard of the casting line. Quickly putting on another fly, I threw in the same place, where another fish hooked directly. Him I had on for perhaps five minutes, but could not get ashore by reason of the logs, and this salmon managed to foul the line and break away with what was left of 
the cast. It was rather discouraging, but we went back again, and the third or fourth cast brought up another fish, which took the fly within a foot of a passing log. Fortunately I was able to get ashore with him, and as soon as I was landed the Indians kept the canoe above me, and with their poles pushed the descending logs out of the way as much as they could. By holding the rod high so as to let such logs as would pass under the line between me and the fish, and dropping the point sometimes below the surface of the water to allow other logs to run over the line, I managed after various narrow escapes from disaster to land this fish and another hooked afterward in the same place, and then stopped, as it was so dark that there was danger of being hit by logs we could not see. Evidently an ascending school of salmon had decided to rest over night in the Judge's Pool. Handling big and lively fish such as these (and they weighed twenty-four and twenty-five pounds), when lots of logs are running and the light fast failing, is about as exciting business as I know of in the angling way, and the enjoyment of it comes mostly after it is over.

Salmon fishing, under the conditions which 
largely prevail on this side of the Atlantic, is an art so easily acquired as to bring it within the compass of the most moderate ability, and withal it yields more pleasure to the lover of sport and of nature than does any other. No properly constituted man can be insensible to the healthful charms of life in the open air, in a world just as God made it, nor to the companionship of the spruce-clad and rugged mountains of the North through which the river has cleft its way, and, full of sparkling ripples, foaming rapids, and swirling eddies, follows in crystal clearness its winding course to finally lose itself in the broad bosom of the ocean. These and many more appeals to the better parts of his nature are the portion of the salmon angler, and his unfailing rewards for blank days and untoward accidents.

Besides, he has the keen satisfaction in many cases of proving his inherited possession of the faculties which enable him to cope successfully with the normal conditions of life, to get along comfortably with meagre conveniences, and to create these by his own ingenuity from the materials offered by nature, and to throw aside for a time, as superfluous and effeminate, the bulk of the customs and luxuries of civilization, which is an 
unconscious delight of a sound mind in approximating aboriginal modes of existence.

Though increasing years lessen the bodily vigor, fortunately they do not take away in the least the mental and spiritual satisfaction in being close to nature in her wilder forms, nor prevent the fullest appreciation of her many varied charms, especially those under the sweet influences of which salmon fishing is practised.

"I count it better pleasure to behold

The Goodly Compasse of the lofty Skye,

And in the midst thereof like burning gold

The flaming chariot of the World's great eye ;

The Watry clouds that in the Ayre uprold

With Sundry Kinds of painted Collours flie ;

And fayre Aurora, lifting up her head,

And blushing, rise from old Tithonus' bed -

"The lofty woods, the forests wide \& long,

Adorned with leaves and branches fresh and green,

In whose cool bours the birds with chaunting song

Do welcome with their Quire the Summer's queen.

The meadowes faire where Flora's gifts among

Are intermixt the verdant grass between -

The Silver skaled fish that softly swimme

Within the brookes and Cristal watry brimme."

-J. D., "Secrets of Angling," I630. 




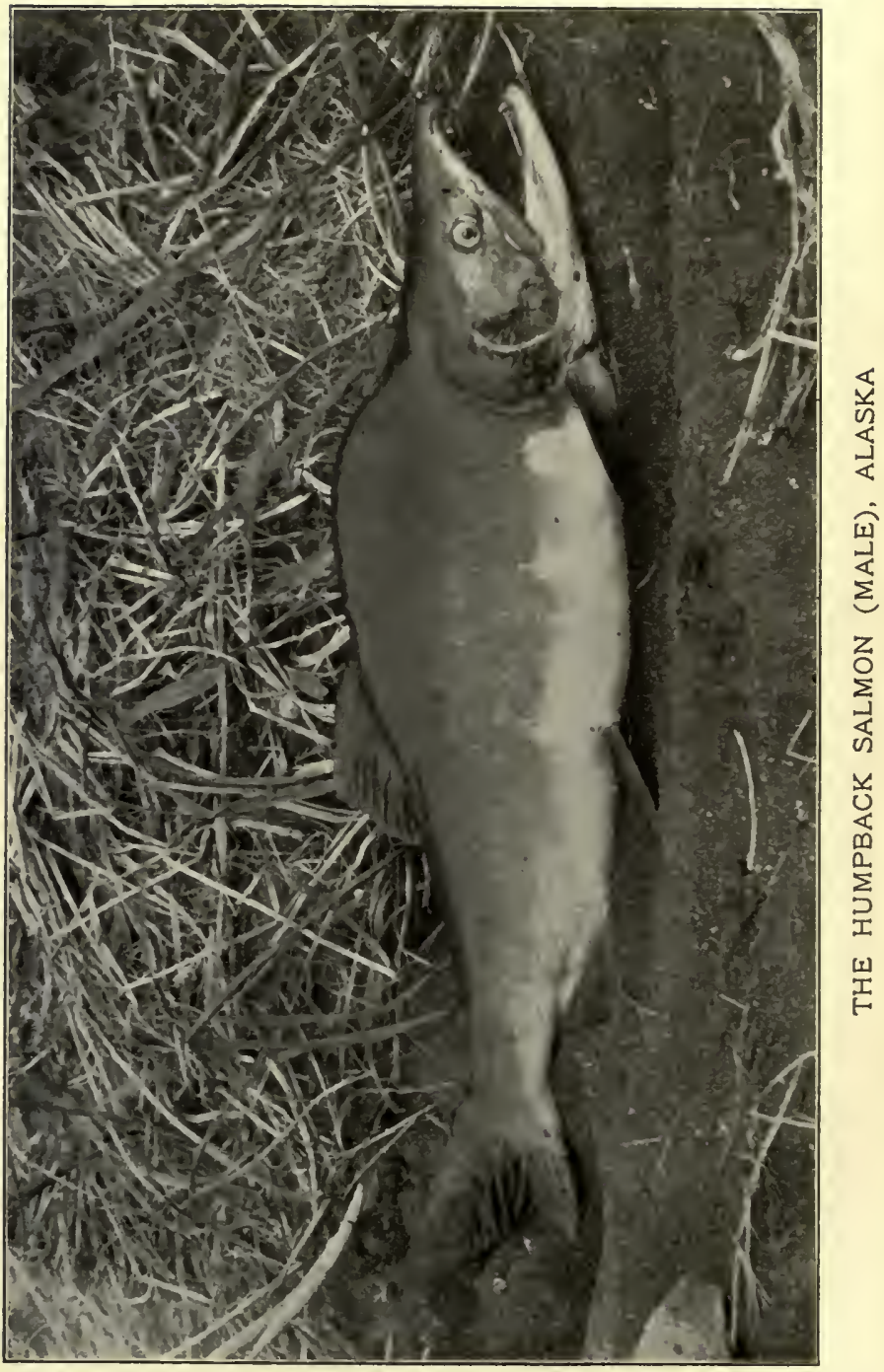




\title{
THE PACIFIC SALMONS
}

\author{
By C. H. Townsend and H. M. Smith
}





\section{THE PACIFIC SALMONS}

\section{DESCRIPTION AND NATURAL HISTORY OF THE SPECIES}

The salmons of the Pacific coast constitute a well-marked group of wide distribution, extraordinary abundance, and great economic importance. No other river fishes in the world support such extensive fisheries, and contribute so largely to the food supply of man; beside them all other salmon are comparatively insignificant.

The genus Oncorhynchus (signifying hooked snout), to which the Pacific salmons belong and which is peculiar to the North Pacific Ocean, is closely related to the genus Salmo, the differences appealing rather to the ichthyologist than to the fisherman or layman. The features separating the two genera consist chiefly in an increased number of anal rays, branchiostegals, gill-rakers, and pyloric cæca in the western fish. The five species of Oncorhynchus differ among themselves in size, color, form, squamation, pyloric append- 
ages, gill-rakers, and other structural details, and are not always readily distinguishable. In addition to the anatomical characters, there is a fundamental physiological difference between the Pacific salmons and the fish of the genus Salmo; the latter spawn several times, while the former invariably die after once spawning.

These fishes have been the subject of many biological investigations on the part of the United States Fish Commission, some of the most important of which have only recently been completed; and the general life history of the most important species is now reasonably well known. The records of that bureau have been freely used in this account of the habits, distribution, cultivation, and commercial value of these fishes.

The quinnat salmon (Oncorhynchus tschazwytscha) bears a number of other names in different regions, such as chinook salmon, tyee, king salmon, Columbia salmon, and Sacramento salmon. The specific name with which this fine fish is encumbered is its Russian vernacular. The euphonious Indian names, quinnat and chinook, are those in most general use. The species may be distinguished by its large size, robust form, conical head, small eye, forked tail, numerous 


\section{Description of the Species}

pyloric cæca (one hundred and forty to one hundred and eighty-five), rather short gill-rakers, about twenty-three in number, anal fin with sixteen rays, fifteen to nineteen branchiostegals, and one hundred and thirty-five to one hundred and fifty-five series of scales between the head and tail; the back has dusky bluish or greenish color, the sides and belly are silvery, the head is dark with a metallic lustre, and the back, dorsal fin, and caudal fin have small black spots.

The geographical range of the quinnat is from Monterey Bay, California, northward to Norton Sound, Alaska, and thence down the Asiatic coast as far as China. It prefers the larger rivers, like the Columbia, the Sacramento, the Nushagak, and the Yukon, which are ascended for long distances, in some instances over one thousand miles; but it also enters many of the shorter coast streams.

This fish is first seen in Monterey Bay as early as January, and many are there caught by anglers for several months, while the fish are frequenting this rendezvous and becoming fat on small fish, preparatory to entering the Golden Gate and beginning their long and last journey up the Sacramento, which stream many have 
entered by February. In March the fish is seen in the Columbia, but not until May does it become abundant there. It seeks the shores of southern Alaska in May, and probably does not reach the Yukon until the latter part of June or early in July. The runs continue for four to six months in the more southern waters, while in northern Alaska the running season is very short, probably not exceeding four to six weeks.

This fish is justly called "royal chinook salmon" and "king salmon" by the people of the Pacific states, for no other salmon in the world compares with it in size. In the Yukon and Norton Sound it attains a weight of one hundred and ten pounds, and in the Columbia of over eighty pounds. Examples weighing forty to sixty pounds are common in the Columbia and Sacramento, and the average weight of those caught in the former stream is nearly twenty-five pounds.

Since the discovery of gold on the upper $\mathrm{Yu}$ kon, large numbers of king salmon, often of huge size, have been taken at Dawson, eighteen hundred miles from the sea, and salmon are known to pass above that point.

The greater part of the life of the salmon is 
spent at sea, where its full growth and sexual maturity are attained. It is the general opinion of authorities that the quinnat does not wander far from the mouth of the stream in which it was hatched; for this reason, and not because of any special homing instinct, it is likely to return to its native river when impelled by the spawning instinct to enter fresh water. Salmon, when seeking fresh water, will sometimes, however, try to ascend rivulets flowing into the sea too small to permit of the passage of such fish at any time. It is a common practice for natives in the Aleutian Islands to seine salmon in abundance along shores where there are no streams whatever, the fish remaining persistently within a few feet of the beaches where there is considerable seepage from the moss-covered hills. This fact shows that they will enter streams other than those from which they were derived. Up to the time the fish enters a stream and begins its migration to the spawning grounds, it continues to feed; but when once its up-stream journey is fairly begun, it loses the ability to eat, owing to the atrophy of its digestive organs.

When just in from the ocean, the quinnat is a handsome, resplendent, shapely fish, although its 
outlines are rather less graceful than those of the Atlantic salmon. Its flesh is of a uniform rich orange-red color, becoming paler and streaked as the spawning season approaches.

According to the observations of the fishermen, salmon appear to pass from the mouth of the Columbia to the Cascades, about one hundred and forty miles, in ten or twelve days. In the rapid upper waters they doubtless travel more slowly.

\section{Sexual Differences}

External sexual differences are scarcely discernible when the salmon first come in from the ocean, but as the time for spawning advances the sexes become more and more dissimilar in appearance. The developing ova give to the female a plump aspect, while the male grows gaunt and thin, and the shape of his head is strongly modified; the jaws become curved and hooked, the eyes are sunken, large teeth appear in both jaws, and his general appearance is savage and repelling.

\section{Sparening}

Spawning begins shortly after the upper waters are reached. The fish, in pairs, usually occupy a position at the upper end of a riffle, where the 


\section{Description of the Species}

current is strong, and where there are stones among which the eggs may lodge. The female extrudes a few eggs and moves away. The male then takes the same place and emits a quantity of milt. In a short time the process is repeated, and this continues day and night for one or two weeks. At irregular intervals, the female turns on her side and forces the tail into the gravel, making an excavation six or eight inches deep and several feet across. Thus are formed the so-called salmon "nests," which are not nests at all, as they are not made for the reception of eggs and do not contain eggs, which are carried farther down-stream by the current. The object of these movements is undoubtedly to loosen the eggs from the ovaries and thus facilitate their expulsion. Doubtless but a small percentage of the eggs deposited are ever fertilized, although, from the equal number of males present, the water must be more or less permeated with the fertilizing product.

Shortly after the spawning act is completed the fish of both sexes die. Since coming into fresh water, their vitality has gradually become reduced, the scales have been absorbed, the fins and tail have become worn off, the skin has been lost 
in places which have been covered with fungus, parasites attack the gills, and death mercifully ensues.

The number of eggs deposited by the quinnat is about three hundred or four hundred for each pound weight of the parent fish. The loss of eggs under natural conditions is large, owing to non-fertilization, to destruction by other fish, and to death by being covered with gravel and sand. The investigations of the United States Fish Commission indicate an average loss of eightyfive per cent from these causes. The eggs which are unmolested hatch in seven to ten weeks in California (four or five months in Alaska), and the alevin stage lasts six weeks longer, during which a further heavy mortality - amounting to twelve or thirteen per cent-occurs. After the young begin to swim they are comparatively free from enemies, and the seaward migration is accomplished without noteworthy diminution in numbers.

The duration of the ocean life of the salmon has not been determined, but recent experiments in the marking of fry have shown that in California and Oregon the quinnat salmon come back to spawn in the second, third, and fourth 
years after hatching, most of them probably returning in the second season.

It is not known whether the large-sized salmon always found in the annual runs are individuals which have encountered conditions unusually favorable for their growth, or are fish that have prolonged their stay in salt water far beyond the customary period.

\section{The Blue-back Salmon}

The blue-back salmon (Oncorhynchus nerka) is known under the name redfish, red salmon, Fraser River salmon, blue-back, and sockeye. It is more abundant than all other species combined, and is the salmon par excellence of Puget Sound, the Fraser River, and Alaska. The species may be recognized by its small size, rather slender form, slightly forked tail, and the following anatomical characters: pyloric cæca slender and seventy-five to ninety-five in number; gill-rakers long and averaging thirty-two to forty; anal fin with fourteen to sixteen rays, branchiostegals thirteen to fifteen; scales in longitudinal series about one hundred and thirty. The fish when fresh from the sea has a bright blue back and silvery sides and under parts, there being no spots anywhere. 
At the spawning period the back and sides become red, and the male develops an extravagantly hooked lower jaw.

The blue-back ranges from northern California to the far north, ascending those streams which rise in cold, snow-fed lakes, and spawning in the affluents of lakes.

It is one of the smallest of the salmon, the maximum weight being only fifteen pounds; specimens weighing over eight pounds are rare, and the average is under five pounds. An interesting form of the blue-back, apparently landlocked in lakes in Idaho, Washington, and elsewhere, weighs only half a pound when mature, and is known as the little redfish.

\section{The Humpback Salmon}

The humpback salmon (Oncorhynchus gorbuscha) is the smallest member of the genus; it rarely reaches a weight of ten pounds, and averages only five pounds. The principal specific characters are the very small scales, two hundred and ten to two hundred and forty in the longitudinal series; slender pyloric cæca, about one hundred and eighty in number; twenty-eight short gill-rakers, fifteen rays in the anal fin, eleven or 



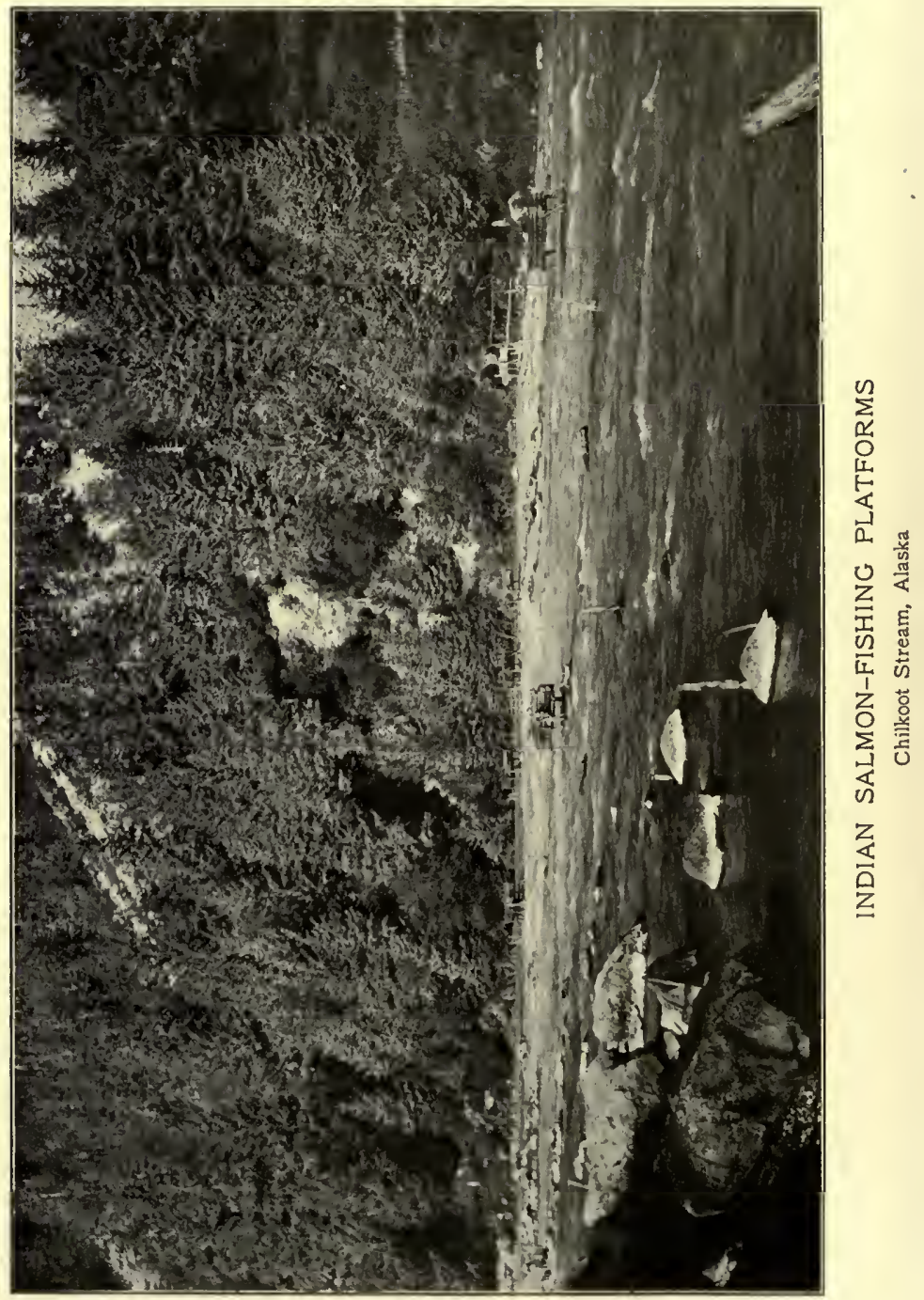


twelve branchiostegals; a bluish color above and silvery on sides; the posterior part of back, adipose fin, and tail with numerous small black spots. It ranges from San Francisco to the Arctic Ocean, and is found in abundance on the Asiatic coast. In Alaska it is the most abundant and generally distributed of the salmons, but in the Pacific States it does not ordinarily occur in great numbers, although there is sometimes a large run in the Puget Sound region.

During the exploration of the Kowak River, which lies within the Arctic Circle, Mr. Townsend found humpback and dog salmon very abundant, the Eskimo from the coast being located in temporary camps along the river for the purpose of drying fish for winter use.

The humpback usually ascends small streams for the purpose of spawning, and often deposits its eggs within a few rods of the sea. When it first comes in from the ocean, it resembles the quinnat salmon in form and color, but as the spawning season advances it develops a large hump on the back, whence the common name. This prominence, together with the distortion of the jaws, gives this species a very striking appearance.

When fresh from the sea the humpback is 
scarcely inferior in food value to any other salmon, but until very recently it has not entered largely into the food supply, the chief consumption being by Alaskan natives.

\section{The Silver Salmon}

The silver salmon (Oncorhynchus kisutch) is also known as silversides, skowitz, kisutch, hoopid, and coho salmon. It has a graceful form, and a brilliant silvery skin. It may be further distinguished by the comparatively few pyloric cæca (forty-five to eighty in number), by the long and slender gill-rakers, of which there are about twenty-three, the short, conical head, long body, small eye, and deeply forked tail. It abounds in short coast streams in Oregon and Washington, and is taken in large numbers in the Columbia River, Puget Sound, and elsewhere. It ranges from San Francisco to Alaska, and thence down the coast of Asia as far as Japan. Although it sometimes attains a weight of thirty pounds, its average weight in the United States is only eight pounds, but in Alaska it is nearly twice as large. In fall and early winter it runs up the streams to spawn, not usually ascending long distances from the ocean. 


\section{The Dog Salmon}

The dog salmon (Oncorhynchus keta) has from one hundred and forty to one hundred and eightyfive pyloric cæca, fifteen short gill-rakers, mediumsized scales, and thirteen or fourteen rays in the anal fin. Its form resembles that of the quinnat. It is dusky above, paler on the sides, and is usually covered with fine spots. The average weight is twelve pounds, and the maximum twenty pounds. Its range is from San Francisco to Kamchatka, although it is not equally abundant in all parts of its habitat, the largest runs being in Alaska. The enlargement and distortion of the jaws, together with its very large teeth, give to this species its common name. It is the least valuable of the salmons. When just from the salt water the flesh has a fine red color and is not unpalatable, but it quickly deteriorates. It spawns in the fall in shallow rivers and creeks.

\section{The Steelhead}

The steelhead (Salmo gairdneri), while in reality a trout, is popularly regarded as a salmon, and on the west coast is known as winter salmon, hardhead, salmon-trout, and square-tailed trout. 
It bears a close resemblance to the Atlantic salmon. Its maximum weight is thirty pounds, and its average ten pounds. It has a wide distribution, ascending nearly all streams from Santa Barbara, California, to the Alaska peninsula. The first run in the Columbia is in the fall, when the fish is in prime condition; but spawning does not occur until February to May. The usual spawning grounds are the head waters of the streams, the steelhead being as indefatigable as the quinnat in pushing its way inland.

It has harder skull bones than the salmons, and its head is of a bright steely color, whence its name.

This admirable fish is a general favorite, on account of its size, beauty, gameness, and food value. It is at its best as a table fish when recently from the sea, and large quantities are then caught for immediate consumption, and also for trans-shipment to the interior and Eastern States. Increasing quantities are also utilized for canning purposes in the Columbia and other rivers.

Unlike the Pacific salmons, it feeds freely in fresh water, and does not die in the streams after spawning, but returns to the sea. This habit 


\section{Feeding in Fresb Water}

demonstrates its generic affinities as clearly as do its anatomical characters.

At the spawning season the jaws of the male steelhead undergo some changes, but not to the great extent that they do in the salmon.

\section{Feeding in Fresh Water}

It may be accepted as an established fact that the Pacific salmons do not feed in fresh water except in rare instances. After leaving tide water the throat becomes contracted, and dissection shows no food in the stomach.

The tendency to feed becomes less the longer they remain, and when one has seen the enormous runs of salmon that sometimes actually crowd the streams, so that it would be impossible to wade without stepping upon them, it becomes apparent that they could not make their rapid journeys to the head waters of the largest rivers and have time to feed, and that there could not be food enough to supply them if they required it. If such hordes should become hungry while on the spawning grounds hundreds of miles from the sea, one could imagine the effect on the spawning operations.

As a matter of fact the salmon, after leaving tide water, lives on its own supply of fat and 
blood. Its flesh becomes less and less red, and the fish becomes thinner as it advances up-stream. In most rivers the salmon arrives on the spawning beds in fair condition, but by the time it has located on the spawning grounds at the head waters of the larger streams it is not merely emaciated, but starved and diseased, and its generally run-down condition is shown in the sores and injuries on its body from head to tail. "Worn to a frazzle" is an expression that might have originated in a description of a Pacific salmon late in the spawning season and far up-stream.

In the process of evolution the salmon may have lost the desire to feed in fresh water through the competition met with in the ascent of the rivers, the great distances to be traversed, and the lack of food in any stream necessary to supply as greatly increased a population of fishes as occurs in the spawning season. Any one who has seen the virgin salmon streams of Alaska knows that no stream could contain food for the legions crowded between its banks at spawning time. If animals remain for a time where there is no food to be had, they must do without it. This is not only true of anadromous fishes, but is illustrated in the case of the male fur seals, which when on 
their breeding rookeries take neither food nor water for two or three months.

The degree of emaciation reached and the extent of the injuries received by the salmon by the time it has spawned preclude the possibility of its recovery even if it reaches salt water alive. Death is a natural result of the conditions.

In Alaska, the humpback and dog salmon, in the last stages of exhaustion, may be seen in brooks after spawning, within a stone's throw of the sea, still struggling up-stream. At this time all desire to feed or return to salt water is gone, the fish linger until they die from exhaustion, and the stream becomes offensive from the abundance of dead fish.

Notwithstanding the fact that the salmon cares little for food when in fresh water and pressing up-stream under the strong instinct to seek its spawning grounds, it can be induced to take the angler's bait or spoon when properly presented, even taking a little food at times on its own account. Perhaps the devices of the angler are more attractive to these sea fish than anything to be found in the streams. There can be no doubt that many salmon are taken by anglers at great distances from the sea, with the spoon and with 
salmon-roe bait. While the ascending salmon has a mission to perform and never loses any time seeking food, it may be induced to take attractive baits that are thrown in its way. Most of those so captured are males.

The fact remains that, while food is sometimes found in the fish, it feeds little and becomes more and more emaciated, until at the conclusion of the spawning season it dies from lack of nutrition.

\section{Cultivation and Acclimatization}

The Pacific salmons received the attention of fish culturists at a comparatively early date, and to-day are among the leading fishes propagated by the general government and the States of the Western seaboard. Owing in part to the extensive fishing, especially that at and near the mouths of rivers, and in part to the pollution of waters and to obstructions, the preservation of these fish is to a very large extent dependent on artificial propagation, and the maintenance of the supply in the face of an enormous annual catch is very generally attributed to the work of the hatcheries.

Associated with the first salmon hatching on the Pacific coast is the name of one of the 


\section{Cultivation and Acclimatization}

pioneers of fish culture. As early as 1873 , when fish culture was still in its infancy, Livingston Stone penetrated what was then the almost unbroken wilderness of northern California, located on the McCloud River, and artificially fertilized and hatched salmon eggs at a little station appropriately called Baird, in honor of one whose services in behalf of the food and game fishes of the country entitle him to the everlasting gratitude of sportsmen, commercial fishermen, and the general public.

From this small beginning at Baird, salmon culture has gradually increased, until now it is carried on at more than a score of government and State hatcheries in California, Oregon, and Washington, at which, in I90I, more than a hundred million eggs were taken and incubated. While the quinnat salmon receives most attention, the blue-back salmon, the silver salmon, the dog salmon, and the steelhead come in for a fair share.

For an account of the interesting methods adopted in the artificial propagation of these spècies, the reader should consult "The Manual of Fish Culture," published by the United States Fish Commission. 
It is not often possible to gage the effects of fish-cultural work in public waters, and this is especially true of the Pacific salmons. Some light has, however, been thrown on this subject by the marking of young salmon prior to their release in the open waters; thus, at the hatchery on the Clackamas River, Oregon, one lot of five thousand fingerling salmon was liberated in 1896 after having the adipose dorsal fins cleanly shaved off with a razor. So many of these fish were subsequently captured as mature individuals as to indicate that an unexpectedly large proportion of young salmon turned out by the hatcheries survive and return to the rivers. Between four and five hundred of the fish so marked are known to have been recaptured, the minimum weight of which was not less than ten thousand pounds. These figures indicate that for every thousand fry liberated, two thousand pounds of adult fish were caught for market. The cost of producing and planting young salmon at the government hatcheries does not exceed one dollar per thousand, and the value of the fish resulting therefrom caught for market is at least $\$ 100$, or five cents per pound.

The possibility of acclimatizing the Pacific 


\section{Cultivation and Acclimatization}

salmons in other waters was early considered, and many large plants of fry were placed in the Atlantic rivers from the Delaware northward; but no noteworthy or lasting results attended these efforts. More recently the attempt has been renewed by the planting of large numbers of yearling fish in the most suitable eastern streams and in the Great Lakes, and strong hopes are entertained that success may eventually be attained. A quinnat weighing over ten pounds was taken on a trolling spoon at the head of the St. Lawrence River in September, I 899; this fish could not have been older than two and one-third years. Another fine example, weighing twelve and one-half pounds, was caught in a gillnet in September, I900. In the spring of 1896 , the planting of steelhead fry in rivers at the western end of Lake Superior was begun. By June, I 897, many young salmon six to eight inches long were caught in the streams, but it was not until the following year that the fish appeared in the lake. In the summer and fall of 1898 steelheads were taken by the commercial fishermen operating along the American and Canadian shores of Lake Superior, and by anglers in several of the streams entering the lake north of Duluth. Fish- 
ermen setting large-meshed gill-nets in deep water for lake trout frequently obtained steelheads fourteen to eighteen inches long, one man at Isle Royal reporting twenty-seven fish thus caught by him. Most of the fish secured in the nets were not gilled, but were held by the dorsal fin after the head had passed through the nets; smallermeshed nets would undoubtedly have taken many more fish. A member of the Duluth fly-casting club states that in two days members of his club caught over four hundred steelheads in Sucker River, he himself taking eighty-five fish in one day; he further reports that he has personal knowledge of not less than twenty-two hundred steelheads taken with hook and line from French and Sucker rivers in $\mathrm{I} \delta 98$. These fish were seven to fourteen inches long, and took the artificial fly as readily as do brook trout. The largest specimen recorded was twenty-eight inches in length.

The quinnat salmon has been transplanted to France, New Zealand, and Australia, but with no very decided benefit up to this time. At the Trocadéro Aquarium in Paris the species has been reared through seven or eight generations in ponds. 


\section{Salmon Fisbing}

\section{Economic Importance of Salmon}

The quantity of salmon taken annually from the waters of the Pacific States, British Columbia, and Alaska is almost past comprehension, and the question may well be asked, How long will the rivers continue to yield these enormous quantities with inadequate protective measures? The yearly drain on the supply now exceeds two hundred and fifty million pounds in the United States and forty-five million pounds in British Columbia, with a market value of more than $\$ 13,000,000$. The great centres of the salmon fishery are the Columbia River, Puget Sound, Fraser River, and Kadiak. As the fish come to the shores and ascend the rivers, they are caught with all kinds of appliances and are incessantly harassed by sealions, white men, and Indians. Large quantities are consumed fresh, but the principal part of the catch is canned. Owing to the rich red color of the flesh, which persists after cooking, the chinook and the blue-back salmon are the most useful for canning purposes. The blue-back is the most valuable species, considered in the aggregate, and is the leading salmon of Puget Sound, Fraser River, and Alaska. The steelhead is taken in 
much smaller numbers than the other species, but its value is relatively higher.

A peculiar method of taking salmon in salt water is practised by the Indians of Washington and British Columbia, called reef-net fishing, in which a large square piece of netting is held between two canoes. The latter are anchored on some reef or other shoal over which the salmon must pass. A lookout is kept, and when the mass of fish are between the two canoes, the net is quickly lifted by the ropes attached to its sides and corners, and emptied into one of the canoes.

In the McCloud, and other streams tributary to the Sacramento, we have seen a method of salmon fishing by Indians practised apparently nowhere else: booths, or lodges, covered with green boughs, are constructed at points just below riffles and rapids, where the fish pause before entering very rapid waters. The lodges overhang the water, and have no more flooring than will afford a seat for the fisherman. From the darkened interior the Indian has a good view of the fish passing underneath, and strikes them readily with a double-pronged spear. 


\section{Salmon Fisbing}

\section{Angling for Salmon}

It took the angler a long time to find out how to fish for Pacific salmon. For a generation people had been catching them in seines and gill-nets, and putting them into tin cans at the rate of millions of dollars' worth a year, but it was not until about ten years ago that sportsmen as a class woke up to the fact that there was good salmon angling in the bays and tidal waters generally.

Information received by the United States Fish Commission from various sources shows that an important quantity of salmon is now taken regularly by trolling, not merely by sportsmen, but by the professional fishermen.

In taking the Pacific salmons, whether in the bays or rivers, the spoon must be depended upon chiefly. Bright feathers attached to the hook are advantageous. In the rivers the best success is usually to be had below falls which the fish have difficulty in passing. We have noticed that salmon may often be taken below the racks placed in the streams near Government fish hatcheries, where their progress was arrested temporarily, when they could not be taken at 
points some distance above, where they were also abundant. Spokane Falls and the Falls of the Willamette are localities well known to salmon anglers.

There is no doubt that, under favorable conditions, the Pacific salmon will take the fly, and it is quite possible that the most attractive fly has not yet been discovered. Much of the fly fishing for salmon on the Pacific coast, however, has really been for steelheads, the angler failing to make the proper distinction.

Salmon may be taken with roe-bait in pools well up in the head waters of the streams. In the McCloud they are easily taken with the spoon, while the young, before leaving the river, will rise to the fly, and are often taken in the spring in trout fishing. On several occasions the grilse accompanying the run of large salmon have been taken with the fly, some of them weighing about four pounds.

In Washington and British Columbia, tidalwater sportsmen take even the largest salmon with the rod and spoon, while the late-running silver salmon often take the fly.

The most southerly point on the Pacific coast where salmon are taken, either commercially or 
for sport, is Monterey Bay, although a few have been caught farther south.

Previous to 1893 few salmon were taken in Monterey Bay by any kind of apparatus, but in that year trolling for them was accidentally introduced during the fishing for mackerel, and both anglers and commercial fishermen were quick to take advantage of the discovery.

This sea fishing has lengthened the salmon season, both for sport and for commercial purposes, and has permitted the marketing the fish at a time when their food value is unsurpassed.

It is surprising that fishermen were not previously aware that salmon entered the bay in considerable numbers, and could be taken with the hook in paying quantities; but this was no doubt due to the fact that salmon in this region do not appear at the surface, jumping and leaping out of water as they do when coming in contact with fresh water. The object of the salmon in entering Monterey Bay is to feed on the sardines, smelts, and squid that are found during the summer months, there being no streams of any considerable size to attract them.

Salmon are taken in Monterey Bay in two 
ways - trolling with spoon, with and without bait, and with baited hook attached below a heavy sinker. Previous to the arrival of sardines, smelts, or other small species on which salmon feed, that is, in quantities to make bait easy to obtain, sportsmen use rod and spoon; but as soon as bait is to be had, this method is abandoned for the sinker hook. As a substitute for bait a bait-spoon is sometimes used, but a baited hook is preferred. Sportsmen who make the trip from San Francisco and elsewhere, use split bamboo rods of various makes, ranging in size from ten to twelve ounces. Occasionally a fancy and expensive rod is seen. A variety of lines is used, both silk and linen, varying in length from one hundred and fifty to two hundred yards; the spoons also vary in size, from Nos. 5 to 7 . As may be supposed, a great variety and many different sizes of hooks are used on the same size of spoon, each angler carrying out his own ideas as to the kind of hook best suited to his wants. The average hook used in connection with a spoon corresponds in size to a No. I4 cod trawl hook with a slightly longer shank. Some use the brazed treble hook; this style is not a favorite among the sportsmen. Mr. A. B. Alexander 


\section{Salmon Fisbing}

states that the "Wilson" spoon, lately introduced, is very effective. It is made in all sizes, No. 6 being most in demand. In shape it resembles the shell of the razor clam, being long and narrow, and rounded at each end. It is claimed that this style of spoon cuts and sheers in the water more than the ordinary spoon, and is more attractive to the salmon. All fishing is carried on from skiffs and small rowboats.

As before stated, as soon as bait is obtainable the above apparatus is abandoned, and the sinker and hook brought into use. This style of fishing gear consists of a linen line, sometimes cotton, size from nine to fifteen thread, with a five-ounce lead sinker having a brass eye in each end to which the line and snood are fastened. The snood is from five to six feet in length, and halfway between the sinker and hook is a small brass box swivel, size No. 4, to admit of the hook turning freely. The hooks vary in size and shape according to taste of the fishermen using them. The average sizes are 8/o, $9 / 0$, and ro/o, some eyed and others flattened. The same kind of rods are used in both methods of fishing.

A great many more salmon are taken with 
baited hooks than with spoons, commercial fishermen seldom if ever using the latter. The professional fishermen's trolling lines are rigged somewhat differently from those used by the sportsmen, although on the same principle. A common bamboo pole answers every purpose, for it is not sport that the fisherman is after, but the greatest number of fish in the shortest time. A fish being hooked, the pole is dropped and the line hauled in hand over hand, skill being exercised in manipulating it so as not to lose the prize. Frequently no rod is used, the line either being held in the hand, or made fast with a halfhitch round the loom of the oar. The line is generally cotton, thirty-two thread, from eighty to one hundred feet in length; hook five inches long, shaped something like a halibut hook, but with the shank longer. In baiting the hook care is taken to have the shank entirely covered, leaving the barb and point bare, hence the object of the extra length. The baits giving the best results are sardines and smelts, and the whole fish is used. The sinker is much heavier than that adopted by the sportsmen, weighing about four pounds, and being fastened to the line twenty-five feet above the hook. The bait is 


\section{Salmon Fisbing}

towed at a depth of at least twenty feet - sometimes the fish are much deeper.

The usual sailing speed in trolling is four miles an hour, and the average size of fish taken is a little over twenty pounds, although fifty pounders are sometimes caught. The best of the season is in June, but there is good fishing well into August; and sometimes salmon are taken here by trolling throughout the winter, as in 1896-97. The best fishing is usually to be had during the forenoon, and twenty-five fish are considered a good day's catch for one hook. Even the commercial fisherman have some sport, as the fish are gamey, nearly all jumping out of the water while being hauled in.

Monterey is the only place on the Pacific coast where an important number of market fishermen use the hook and line for salmon. The fishing has increased steadily each year since its beginning, and in 1901 there were taken by this method approximately 190,786 pounds of salmon, or about I0,000 fish in number, most of which were placed in cold storage and shipped to various parts of the East. About one hundred boats were engaged.

In the Eel River, in northern California, there is good salmon trolling in the fall. The fish are 
taken in tide water, chiefly by professional fishermen, using from twenty to thirty boats; but many anglers come for sport fishing, and occasionally capture fish weighing forty or fifty pounds. It takes the sportsman an hour on the average to land one of the larger fish.

Only a few salmon have been taken by trolling in San Francisco Bay and the Sacramento River. At Red Bluff and other points farther up the Sacramento River, in places not over four hundred or five hundred feet wide, farmers and other people living in the vicinity place lines across the stream, to which are attached seven or eight spoons, equal distances apart, suspended from the main line by snoods about two feet long, thus forming what might be termed a surface trawl. The current striking the line keeps the spoons in motion, which answers the same purpose as a spoon on a line handled from a boat. In this way six or eight salmon are sometimes taken in a day on a single line. No bait is used, and no fishing is performed along the banks of the river with either fly or spoon. At Battle Creek in the same region salmon are frequently taken by casting a spoon below the racks used in closing the stream near the government fish hatchery. 



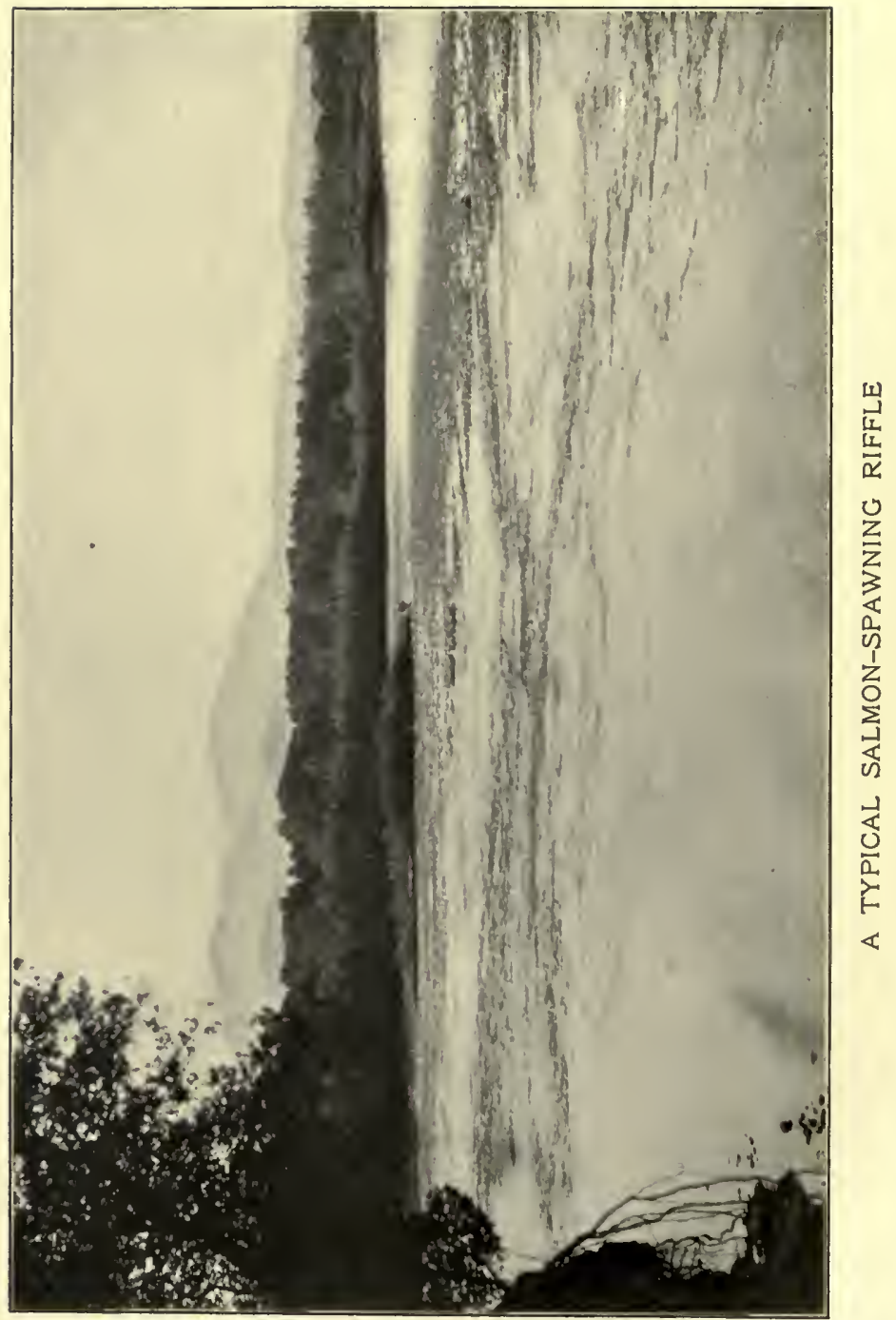


The Indians of Neah Bay, Washington, do a considerable business in trolling for silver salmon, and have been known to take as many as four thousand fish in a day. The principal fishing grounds lie off the mouth of the bay, in the vicinity of Tatoosh Rock, and some two or three miles farther south. The catch is mostly shipped to a cannery at Port Townsend.

Early in the morning the Indians repair to the grounds, remaining out all day, and sometimes after dark, the weather permitting. The spoons are about two sizes larger than those used elsewhere on the coast, with no increase in the size of the hook. Trolling lines are usually white cotton, sometimes tanned, size thirty thread. A complete fishing outfit consists only of a line one hundred and fifty feet long and a trolling spoon. Pieces of salmon and small herring are used for bait.

In trolling, the canoe is paddled, except in very light breezes, when the sail is set. The line is held in the hand which grasps the upper part of the paddle. When a fish is hooked the paddle is thrown into the bottom of the canoe and a straight overhand pull begins. The canoe being light, her headway soon stops, which lessens the 
strain on the line, thereby increasing the chances of securing the salmon.

Salmon trolling is performed in the same way and with the same kind of tackle off Seattle and in other parts of Puget Sound. Sportsmen, however, are much given to using rod and reel and playing the fish, deriving more pleasure in landing one fish in this way than in taking a dozen salmon after the manner of the market fishermen.

At Killisnoo, Alaska, the run of king salmon that strike the coast readily take a spoon. They come in to feed on the herring which annually visit these waters. Spoons and lines of the same pattern and size are employed by the Killisnoo Indians as at Neah Bay, and the same kind of bait is used. The fish taken are for home consumption. At times when salmon will not take a spoon at the surface, a baited hook lowered to the bottom frequently induces them to bite.

There can be no doubt that there are many places along the west coast where salmon could be taken by trolling just as well as at Monterey and off Cape Flattery. During the survey of ocean fishing banks off the Oregon coast by the Fish Commission steamer Albatross, two or three 
salmon were hooked on the cod lines used in testing the fishing grounds. These were taken four or five miles off shore in probably thirty fathoms. In a few instances salmon have been hooked on common fishing gear from four to six miles off the coast of Washington in thirty to forty fathoms. One fishing captain took thirteen chinook salmon six miles off the Washington coast by trolling at thirty fathoms where the soundings were forty fathoms, and another fisherman took one chinook six miles farther out. It now seems probable that a thorough trial by deep trolling all along our coast will show that the salmon are "on soundings" during a considerable part of the time they spend at sea.

\section{Angling for Steelheads}

The fishing season is not limited to the time that the steelhead is in the rivers, for it may be found in the lower tidal waters at almost any time of the year. In the coast rivers of northern California it may be taken from early in the fall until midwinter.

There is especially good fishing for the steelhead in the Russian, Navarro, and Eel rivers north of San Francisco in the fall, and it may be 
taken with the spoon or with a variety of flies. Ten-pound fish are about the usual size, and each may be depended upon to furnish a long fight.

During the open season many anglers from San Francisco fish for steelheads in Olema River and about the head of Tomales Bay. The spoon for taking the steelhead is much smaller than that used for salmon in Monterey Bay, although different sizes are found among fishermen, ranging from Nos. 2 to 5. The lines are mostly silk, fifty yards being about the maximum length. Worms, grasshoppers, and minnows are used for bait in spoon casting. Some anglers cannot be induced to use bait, much preferring fly fishing. Flies of the usual varieties found in anglers' fly books are brought into use in fishing this stream. Men and boys living in this locality, not possessing the expensive tackle of the anglers, fish with common bamboo poles, both with and without reels; some have silk lines, but the majority use linen lines. Fishing is done almost wholly from the banks of the river, wading the stream, and from marshy points projecting into the bay, and occasionally from a small boat or skiff anchored off some favorite spot near the shore. 
During the run of steelheads in Eel River many anglers from San Francisco find excellent sport there. The river is fished by trolling from a boat, whipping the stream with rod and fly, and baited snelled hook. The bait changes with the season, and in fly fishing a great variety is used, repeated changes being made according to the time of day and the condition of the weather. The general favorite, however, is the small red fly. A twelve-ounce split bamboo rod is mostly used, both in trolling and fishing with fly. The spoons used are the Wilson pattern, Nos. 3, 4, and 5 , and the average length of line is one hundred yards; it is of the best quality of solid silk, Nos. 4 and 5 being the standard sizes. Three feet above the spoon is a piece of sheet lead wound round the line, weighing from four to five ounces. In shallow parts of the river the lead acts as a protection to the spoon, giving warning to the fishermen when the hook is near the bottom. Some fishermen attach a gut leader above the spoon, but others claim that fish are lost by it. It is said that large spoons take large fish, and that it seldom happens that a fish of any considerable size is caught on a small spoon. A great deal of salmon roe is used for 
bait, as well as pieces of salmon cut into narrow strips.

It has been stated that the steelhead does not ascend the Sacramento as far as the McCloud, but we saw one there in 1884 . It was recognized as a rarity by the men engaged in taking salmon eggs for the government hatchery and was saved for identification.

The mere fact that the steelhead belongs technically to the trouts and not to the salmons should not affect its reputation as a game fish. It is probably as gamey a fish as the Atlantic salmon, and it is large-sized and fights well when hooked. No one thought of calling it anything but a salmon until the naturalists pointed out the characters that identified it as a trout. To most of the people of the west coast it is still a salmon.

A time is coming when there will be an army of anglers fishing for the steelhead in all the beautiful streams of the west coast from the Russian River to the Straits of Fuca. 
THE TROUTS OF AMERICA By William C. HARRIS 



\section{THE TROUTS OF AMERICA}

\section{CHAPTER I}

ANGLING, ITS ANTIQUITY AND LITERATURE-DISTRIBUTION OF TROUTS AND CHARRS - CLASSIFICATION-NATIVE TROUTS AND FOREIGN SPECIES INTRODUCED TO AMERICAN WATERS

ThE literature of ichthyology and angling is as old, doubtless older, than the classics. When Socrates was teaching philosophy in the academic groves of ancient Athens, and Diogenes was still in prime cynical vigor, Herodotus, the pioneer in ichthyic research, in the fifth century before the Christian era, was engaged in stream observation and in the study of zoölogy, direct and comparative. Oppian, in the second century, gave to the Roman world, in his "Halieutica," the first treatise on fishing, and earlier still, the old Greeks practised the art of angling, for Homer tells us:-

" Of beetling rocks that overhang the flood,

Where silent anglers cast insidious food,

With fraudful care await the finny prize, And sudden lift it quivering to the skies." 
The Macedonians, before the age of Alexander the Great, used a crude fly made of purple wool with wings, which they called the "hippurus"; it was said to be of the size of a hornet, marked like a wasp, and when manipulated, buzzed like a bee; it was used to lure the fishes of the river Astreus and those of smaller " streams, which were said by Ælian to have been "speckled fishes."

In the prophecies of Isaiah, chap. xix. ver. 8, the unrighteous fishermen are warned in these words :

"The fishers also shall mourn and all they that cast angles into the brooks."

In 1486, six years before the discovery of America, Wynken de Worde, among the first of English printers, published that famous work, "The Booke of St. Albans" on "the dyssporte of fysshyng" by Dame Juliana Berners or Barnes, the Prioress of Sopwell in England; it was the first book on fish and fishing printed in the English language.

From about the same period we have handed down to us a canticle sung by the monks, the words of which are redolent with the spirit of angling:- 
"The sun was setting and vespers done, the monks came one by one,

And down they went through the garden trim in cassock and cowl to the river's brim,

Every brother his rod he took, every rod had a line and hook, Every hook had a bait so fine, and thus they sang in the even shine,

'Oh! to-morrow will be Friday, so we fish the stream to-day! $\mathrm{Oh}$ ! to-morrow will be Friday, so we fish the stream today !'-Benedicite."

The old dame, among her other unctuous surroundings as Prioress of Sopwell, had the pike and the carp, and, doubtless, the perch and tench, in the ponds of the Priory, with the red-spotted brown trout coursing a brook not distant. To fish on Thursday for Friday's meals was not only a delight but a necessity for these hooded disciples of the craft, and the refrain of the old canticle and the jollity of the air of it, accentuated, as it doubtless was by the lifting of a fat carp from the adjacent moat, or, perhaps, a lusty trout from the near-by stream, stirred their blood even as ours leaps to-day when the monarch of the brook is braving skill and tackle.

Nearly two hundred years after the publication of "The Booke of St. Albans," Walton wrote his angling idyl, "The Compleat Angler," and 


\section{6

from 1653 , the year in which it was printed, to the present time, about thirty-five hundred works on angling, in various popular and édition-deluxe forms, have been published.

With these records before them, angling students are inclined to believe that "the speckled fish" lured by the ancient Macedonians with an artificial fly or bug, were either trout or closely allied to that genus. Also, that the prophet Isaiah in the use of the words, "they that cast angles into the brooks," had reference to a practice identical or similar to that of modern flyfishing, more particularly, as it was reported by a correspondent of The American Angler, some ten years ago, that he had found a varietal form of the charr-trout in the upper waters of the River Jordan.

Certainly no fishes of the fresh waters, except possibly the small cyprinoids, or carplike minnows, have a greater or more general distribution, above latitude $40^{\circ}$, than those of the salmon family, particularly the so-called trouts. Wherever water exists of a temperature not higher than $65^{\circ}$, the trout will be found, or can be successfully planted and increased. In swiftly running, highly aërated waters they have been known 
to live, but not thrive lustily, when the temperature is slightly over $70^{\circ}$. Such water conditions exist all over the temperate zone, and in the elevated portions of the semi-tropical. At the present day these fish are found on the western coast of America from the Arctic Circle to the head of the Gulf of California, and in the streams of the northern mountains of Mexico. In the Old World they have been discovered as far south as the Atlas Mountains of Africa, the mountain streams of Persia, and in the Hindu Kush or Indian Caucasus of the colossal range of the Himalayas.

On the eastern coast of North America, the red-spotted charr-trout (fontinalis) is found from Labrador south to the head waters of the Savannah, Chattahoochee, Catawba, and French Broad rivers; and west and northwest of the Mississippi we find at least twenty-three species of our socalled indigenous salmon-trouts, some of them leaping and flashing from the waters of Kamchatka, while their congeners are disporting in the mountain streams of Arizona and in the lakes of Mexico.

The many species of trout of the streams west of the Mississippi are not considered indigenous 
to North American waters, for it is now the consensus of opinion among American ichthyologists that these fish originated in Asia, crossing Behring Straits or the adjacent sea, and passing southward and eastward to the Upper Columbia, thence to the Yellowstone and Missouri rivers; from the Missouri southward to the Platte and the Arkansas, and from there being generally distributed over the Pacific slope from the Fraser River southward. Be this as it may, and at best it is merely an ichthyic theory; we find the original parent fish, after leaving their Asian Eden, multiplying in Western waters into twenty-four species of trout, all black spotted save one, the Dolly Varden. East of the Mississippi thirteen species and subspecies of the charr-trouts exist, including the lake trout or togue (Namaycush), which is also found in the extreme northwest as far as the Arctic Circle, and excluding the Dolly Varden, which is a charr of the Pacific slope.

In Great Britain and on the eastern continent not less than ten species of trout and charrs are known under specific classification. We find non-migratory trout in the waters of Hungary, Switzerland, France, Bavaria, Italy, Norway, 



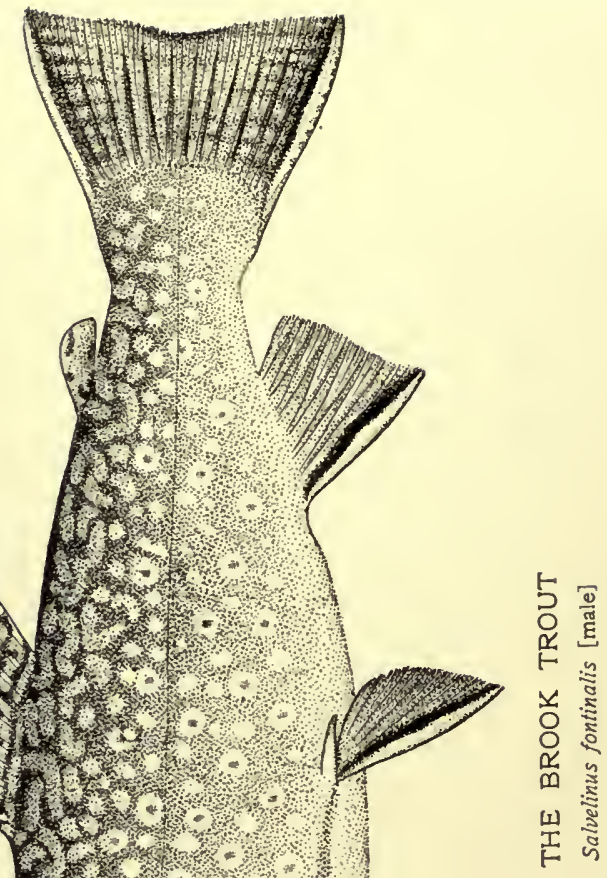


Sweden, Siberia, Lapland, and in Algeria and India; and migratory species along the shores of Europe, Northern Asia, and even as far south as the Crimea, and at the entrance of the harbor of Sebastopol. From the geographical situation and climate of the Scandinavian Peninsula it may be inferred that it is inhabited by a greater number of species of salmonoids than exist in other sections of the Continent or in Great Britain.

Constant additions are being made in the discovery of new species or varietal forms, and in the opinion of many European ichthyologists the hybrids of the charrs and salmon-trouts are adding to the number of confused and complicated species, until Günther, one of the most prominent fish savants, is obliged to confess :-

"We know no other group of fishes which offers so many difficulties to the ichthyologist, with regard to the distinction of species as well as to certain points in their life history as this genus $($ Salmo). . . . The almost infinite variations of these fishes are dependent on age, sex, and sexual development, food, and the properties of the water. Some of the species interbreed, and the hybrids mix again with one of the parent 
species, thus producing an offspring more or less similar to the pure breed. ...."

To add to this confusion in the identification and classification of species, other potent factors exist, of which the widely variant coloration is not the least. Trout of the same species, when found in widely separated waters, and in some instances in the same habitat, very often present striking differentiation in color and physique. I have found three distinct forms and standards of coloration in the same species of Rocky Mountain trout, the cut-throat or black-spotted trout (Salmo clarkii). Those of the Yellowstone River have stout bodies and yellow coloration of rather a dense hue; those of the Gallatin River are not so stout at the shoulders, and have a bright silvery coating, while the Elk Creek fish is more clipper-built, has a cleaner run than his congeners of the Yellowstone and Gallatin, with a more brilliant silvery sheen, barred with brown. Age does not seem to alter these conditions, for a half-pound fish, caught in either of the waters named, is as characteristically marked as one weighing a pound, and these streams are all in Montana and not distant more than three hundred miles, as the crow flies, one from the other. 
All these fish are classed under the cut-throat species because of the crimson slash appearing on the under jaw or throat-latch; but this marking is frequently indistinct and occasionally absent, and to render confusion more pronounced, these cut-throat trout frequently have a faint, sometimes bright, pinkish lateral band upon them, thus encroaching on the distinctive marking of the rainbow series of fishes.

In Wood River, a few miles from Ketchum, in southern Idaho, I have taken a trout with no tracing of the crimson markings on the throatlatch or lower jaw, but with a bright, broad band of pink along the lateral line, and have not, as yet, been satisfied as to its correct classification - it may have been a cut-throat, or it may have been a rainbow, for we are told by ichthyologists that the three series of western salmon-trouts the cut-throat, rainbow, and steelhead - are only provisionally retained as distinct, the prominent differentiation between them being only in the number and size of the scales and the apparently diverse coloration of the fish.

Anglers all know that the male of the eastern red-spotted trout (fontinalis) is much more highly colored during the spawning season than 
at any other period of the year. The same is true of the sea salmon and all others of the same family, including those of the Rocky Mountains and other waters of the far West, and doubtless nature has bestowed upon the male trout increased beauty of coloration during the erotic period to enhance his charms and render his amours more fascinating to the female.

Thus it will be seen that coloration is not to be depended upon in distinguishing species, there being seldom found a trout which in all its stages of development will present an uniform coloration. The prevailing marking of all young salmonoids, trout particularly, is the dark bars running transversely across the body. These disappear when the fish reaches a length of six to eight inches, and yet I found the trout of Elk Creek, Montana, to retain these markings at all stages of their growth.

Again, the properties of the water, its depth and slowness or rapidity of current, have a visible effect upon the coloration of trout. On the Ontonagon River, Michigan, about twelve miles north of the Wisconsin line, there is a quiet stretch of water nearly two hundred feet in 


\section{Distribution}

length, densely bordered by a growth of overhanging alders. Under these, and at a depth of five or six feet, the trout lie in wait for falling insects. These fish, when freshly taken from the water, are found to be of dark coloration, the vermiculations or mottlings on the back but faintly outlined, yet the red or crimson spots are more brilliant than ordinarily occurs. They are stouter than usual at the shoulders, the body broader and more aldermanic in its proportions; they are well fed, do not have to forage vigorously for food, and rise to an artificial fly leisurely and lazily. One hundred feet above this pool is another, smaller and more shallow, into and out of which turbulent rapids pour. Take a fish, as I have done, from this swim, and he will be found of lighter coloration, a slimmer and cleaner-cut body, with the olive mottlings on his back clearly outlined, and the red spots not so bright. Near the head of the large pool named there is a little rill that flows into the river over a shallow sand bar, some ten inches in depth, and about five feet broad. The trout from the deeper reaches of the still water occasionally come on this bar, probably to bask in the sun, as there is apparently no food there for them. In a few moments their 
dark bodies assume a lighter shade, the anterior streak of dirty white on their belly fins becomes of a richer cream, and the wormlike markings on the back change from blackish to dark olive clearly and strikingly defined. These changes in coloration are certainly involuntary and are a provision of nature to protect them from their enemies of the air and water.

Again, we find that the difference in size and in the proportions of the body in trout of the same age, present further difficulties in identification of species. The head especially is subject to great alteration as the fish grows to maturity; the fins, according to Gunther, of those inhabiting rapid streams, as well as still waters, show considerable variations in form and length; those of the fish in rapid water being in almost constant motion causes the wearing off of the delicate extremities, hence the fin-rays are comparatively shorter, stouter, and of a more rounded form. Moreover, one and the same individual may pass a part of its life in a lake, and enter a river at certain periods, thus changing the form of its fins, as well as general coloration, almost periodically.

Thus it will be seen that exact classification in 
our fish fauna must be based upon anatomical lines, the structure of internal organs; for to depend upon the difference in individual fishes in shape, coloration, size of the head at certain stages of growth, spread and shape of tail, or variation in weight, would be like building up a new classification for the human family based upon the phrenological lines of the head, size and flop of ears, pedal spread, freckles or no freckles, excessive youthful growth or height or rotundity in individuals.

From this rich but somewhat incongruous material at their command, ichthyologists have classified the trouts of American waters into salmon-trouts and charr-trouts. None of the former is indigenous to the waters east of the Mississippi River, and but one of the latter the Dolly Varden - is a native of the Pacific slope. The lake trout (a large, coarse charr) is found in Eastern waters, and northwest as far as the Arctic Circle; and in this connection anglers should bear in mind that the word "trout" in general use and so indiscriminately employed to designate all species of their favorite fish, should be discarded: the "trout" (Salvelinus), so called, of Eastern waters are all charrs except the 
imported species of salmon-trouts from abroad and from the far West. The trouts proper (Salmo) are the salmon-trouts of foreign importation, and those indigenous to waters west of the Mississippi River.

This classification of the trouts is based upon anatomical differences of structure in the two genera, the details of which will be given as each fish is treated separately: they consist mainly in the arrangement and location of the teeth. If an angler is in doubt as to the proper generic status of his trout or charr, he has only to put his finger in the mouth of the fish, and if a single or double row of teeth is found on the front and rear part of the bone on the roof of the mouth, he holds in his hand a salmon-trout; if only a single patch exists in the rear of the bone, he has a charr-trout under inspection. It must be remembered, however, that sometimes these teeth are accidentally lost, and that they disappear gradually with age, and at times they will be found placed alternately rather than in a double or single series; but in all species of our American trouts, the rule as above given should be found sufficient for identification; the angler, if in doubt, being careful to examine several fish of the same species. It should also 


\section{Classification}

be stated that the surest external physical characteristic which may be said to be constant in each species and by which identification is assured, is the size of the scales as shown in the number of vertical series between the front of the dorsal fin and the lateral line; but as these scales are almost microscopic in most of our American trouts, and as the skin on the back of old male trouts is apt to become spongy and thick, the scales becoming invisible from being embedded in the skin, this test is beyond the reach of the ordinary angler on the stream.

The ichthyologist seeks for correct classification of Salmonidæ primarily in the number of vertebræ; the number of pyloric appendages, or blind sacs opening into the alimentary canal; the form of the preopercle or anterior gill cover; width and strength of the maxillary or upper jaw; size of teeth and their arrangement and permanence on the vomer - the bone on the roof of the mouth; the development or absence of teeth on the hyoid bone at the base of the tongue; size and number of scales, as above stated; development of the pectoral and caudal fins; the number of gill-rakers, a series of bony appendages along the inner edge of the gill 
arch; and the rays and pines in the formation of the fins.

It may be well before going farther to warn the layman-naturalist and angler against the common use of the phrase "salmon-trout." In every section of the country, on the Pacific Slope as well as on the Atlantic, whenever a big steelhead, cut-throat, rainbow, or any other trout, sea-run or otherwise, of unusual size is taken, it is baptized at once a "salmon-trout," without designation of species; and the same popular name is given in the Middle West and East to the Great Lake trout or togue, which is purely a coarse charr-trout. Popular and local nomenclature is becoming more mixed and confusing with each fishing season, and before many more pass away, our legislators will be obliged to use the technical scientific names of fishes that they may be identified for protection under the law.

That the layman-angler may have a still clearer perception of the present classification of the blackspotted or cut-throat series of salmon-trouts, I quote Jordan and Evermann, the editors of "The Fishes of North and Middle America," published by authority of the Smithsonian Institution:-

"It is not unlikely that when the waters of the 


\section{Classification}

Northern Hemisphere are fully explored, it will be found that all the black-spotted trout of America, Europe, and Asia are forms of one species, for which the oldest name is Salmo trutta" (the sea-trout of Europe and Asia). 


\section{CHAPTER II}

THE SALMON-TROUTS - THE CUT-THROAT SERIES -POPULAR AND TECHNICAL NAMES-SOMKA OR MYKISS TROUT OF KAMCHATKA - COLUMBIA RIVER TROUT - ROCKY MOUNTAIN OR CUT-THROAT TROUT - YELLOWSTONE RIVER TROUT - TROUT OF IDAHO AND WASHINGTON - RIO GRANDE TROUT

Excluding the German or brown trout, the seatrout of Europe and the Loch Leven form from Scotland, all of which except the sea-trout have been very generally introduced into American waters, our indigenous salmon-trouts are named and classed as follows:-

The Cut-throat or Columbia River trout, -

Salmo clarkii (Richards). The Yellowstone trout, - Salmo clarkii lewisi (Girard). The varietal form from Idaho and Washington (no popular name), - Salmo clarkii gibbsii (Buckley).

The Lake Tahoe, Truckee, or " pogy" trout, -

Salmo clarkii henshawi (Gill \& Jordan). The Silver trout of Lake Tahoe, - Salmo clarkii tahoensis. The trout of Utah Lake, - Salmo clarkii virginalis (Girard). The Rio Grande trout, - Salmo clarkii spilurus (Cope). 


\section{Popular and Tecbnical Names 2 II}

The Colorado River trout, - Salmo clarkii pleuriticus (Cope).

The Waha Lake trout, - Salmo clarkii bouvieri (Bendire).

The Green-back trout, - Salmo clarkii stomias (Cope).

The Yellow-fin trout, -

Salmo clarkii macdonaldi (Jordan \& Evermann).

The Salmon trout of Lake Sutherland, Wash., -

Salmo clarkii declivifrons (Meek).

The Spotted trout of Lake Sutherland, Wash., -

Salmo clarkii jordana (Meek).

(All the above are varietal forms of the cut-throat series.)

The different forms of the steelhead series are:-

The typical Steelhead or hardhead trout, -

Salmo gairdneri (Richardson).

(Called "Salmon-trout" on the Pacific Coast.)

The Kamloops or stit-tse trout, -

Salmo gairdneri kamloops (Jordan).

The Blue-back trout of Lake Crescent, Wash., -

Salmo gairdneri beardsleei (Jordan \& Seale).

The Speckled trout of Lake Crescent, -

Salmo gairdneri crescentis (Jordan \& Beardslee).

The varieties of the rainbow are:-

The Rainbow trout or Coast Range trout, -

The Brook trout of western Oregon, -

Salmo irideus (Gibbons).

Salmo irideus masoni (Suckley).

The McCloud River (Cal.) trout, -

Salmo irideus shasta (Jordan).

The Kern River (Cal.) trout, - Salmo irideus gilberti (Jordan). 
The Nissuee or no-shee trout, - Salmo irideus stonei (Jordan). The Golden trout of Mt. Whitney,-

Salmo irideus agua bonita (Jordan). The Long-headed trout of Lake Crescent, Wash., -

Salmo bathoecetor (Meek).

From this list it will be seen that we have twenty-four forms of salmon-trouts in the waters of North America, to which should be added three imported species, - the brown or German trout, Salmo fario, the Lock Leven trout, Salmo levenensis, and the European sea-trout, Salmo trutta; the latter has been recently introduced, but not to a great extent.

A few years ago the above forms of the cutthroat were all known as Salmo mykiss, with various subspecific names, and credit assigned to Walbaum, as the first ichthyologist who classified and named them; but it has been found that the true mykiss (a vernacular name, also called by the natives "somka" and "salmon-trout") is confined to the waters of Kamchatka, where it is said that it differs from our native cut-throat by the absence of red slashes on the throat latch, and by the small number of black spots sparsely distributed on the body and fins. It is evidently closely allied to the Atlantic sea-salmon, 



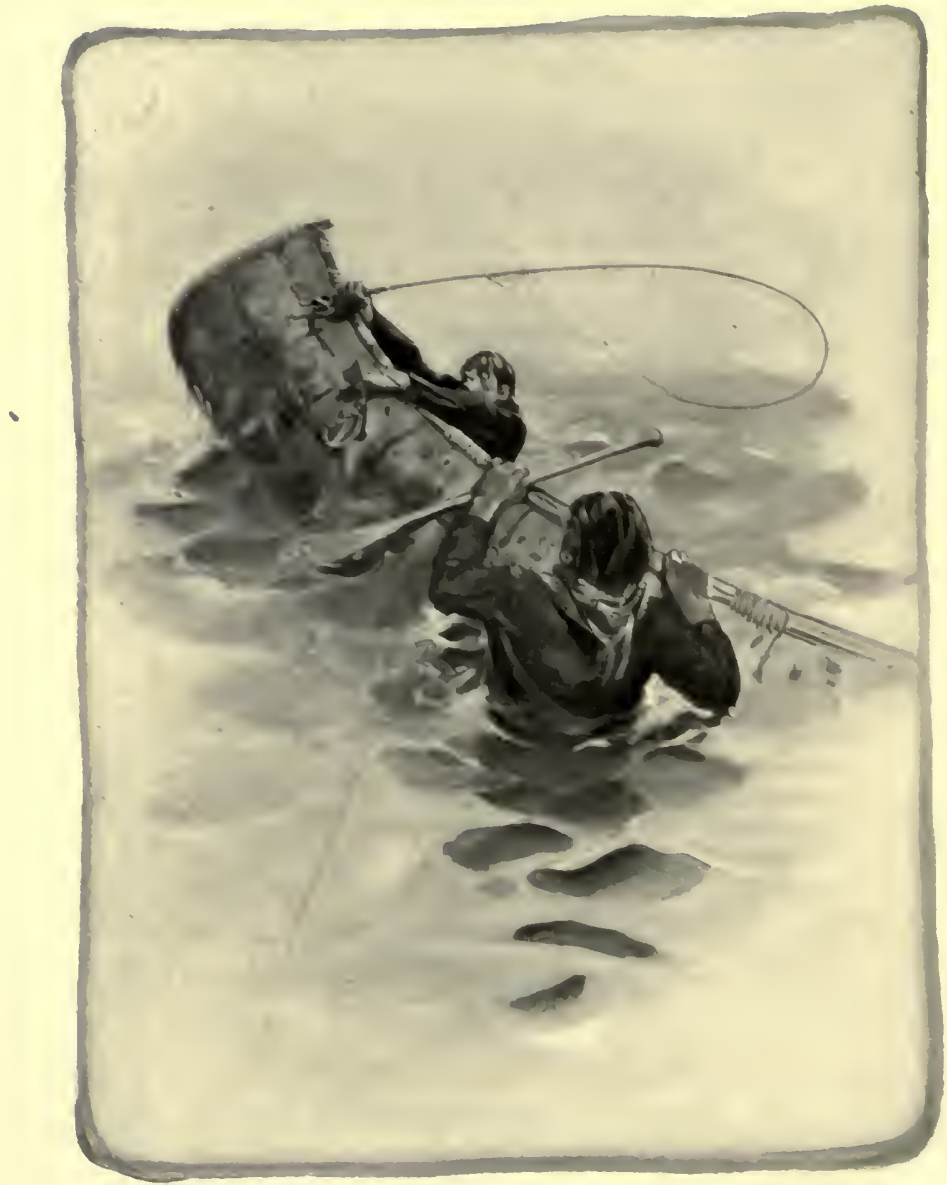

HIS FIRST TROUT 


\section{Cut-Tbroat Trout}

and, except for the mouth being slightly larger, differs from it only in very few, if in any, other characteristics.

It is my purpose, so far as I may be able, in these monographs of American trouts and charrs, to give brief life histories of each fish, with their markings and coloration sufficiently individualized that the angler, with these notes at hand, will be able to distinguish on sight the species of fish he has netted. With this object in view I have avoided, so far as possible, the technical phraseology which renders works on ichthyology uninteresting and often unintelligible to the average reader of books on fish and fishing.

The typical American cut-throat, or Columbia River trout (Salmo clarkii), ranges in the coastwise streams of Puget Sound south to Elk River, Humboldt County, California, and its various forms eastward to the head waters of the Rio Grande and the Utah Basin. I have taken a subspecies in the Upper Missouri, and others are reported as found in the highest sources of the Kansas River; another form is said to be in the mountain streams of Mexico, and, as before stated, the parent fish are believed to have originally migrated from Asian waters. No true cut-throat, 
however, has as yet been found in American streams north of Wrangel, Alaska.

The Columbia River trout has a moderatesized mouth, the upper jaw not reaching posteriorly far beyond the eyes, and the body, as a rule, is long, somewhat compressed, and the head is rather short. The length of the body is usually four times its breadth, and the head (from the snout to posterior gill cover) is about as long as the depth of the fish. The scales are small, and there are about ten rays in the first dorsal, or back fin, and the same number in the anal fin on the posterior part of the belly. The red slash on the throat is said to be always distinct, and there are numerous round black spots on the back of various sizes which often extend to the belly. While the cut-throat is said always to have the crimson or deep red blotch on the lower inner edge of the mandibles (lower jaws), the general coloration is extremely variable. The ichthyic authorities state that only the male of this species has a reddish lateral band and patches of light red on the body. If this be so, I had an unique experience among them in the Upper Spokane River, Washington. I fished an entire morning and caught a large number of these fish, a specimen 


\section{Cut-Tbroat Trout}

of which was at once sent to Washington, D.C., for identification, where it was pronounced to be the cut-throat trout (Salmo purpuratus was its technical name at that time, more than ten years ago). Every fish taken on my rod was exactly alike in form and coloration, and each had the broad crimson band along the lateral line. Doubtless, the Spokane River has become depopulated of these fishes, for apparently there were no female cut-throats in it to continue the species, as my companion's rod and my own captured not less than three or four score of these trout, and, according to the authorities, there was not a single representative of the gentle sex among them. A somewhat similar experience occurred on one of my Western outings on the Bitter Root River in Montana.

The habits of the cut-throat trout are similar to those of his Eastern brother, the red-spotted trout (fontinalis). Wherever a pool existed, created by an offshoot from the main stream, wherein a shelving rock or overhanging trees formed a sheltering or shady nook, we always found a single cut-throat of good size, sovereign of the domain from which he had driven the grayling and the whitefish. In the larger pools, caused by the subsidence of the 
current in deeper water, he appeared to live in harmony with these fish. The Montana grayling and the cut-throat do not war upon each other; the red-spotted trout of Michigan and the grayling are antagonistic, and the latter fish is gradually becoming extinct, the most probable cause being that the grayling spawn in the spring, and the trout, spawning in the fall and having recuperated from its debilitating effects, and huge in appetite after a winter's hibernation, devastate the spawning beds of the grayling; for no lure or food is so attractive to the salmon family as their own ova. On the other hand, the grayling of England (Thymallus vulgaris), when living in the same water with the brown or German trout, a robust fish growing to a large size, gets the upper hand, and the trout decrease in numbers and somewhat in quality. In Montana waters the river whitefish, as well as the trout and grayling, apparently live in amity, and all thrive apace.

Wherever the cut-throat lives in the lower waters of streams or coastwise ponds or lakes, with access to salt water, he may be found also in the bays and tributaries, and doubtless ranges seaward as far as the salmon. Under this condition, a silvery coating is assumed and the black spots, 
with which the body is more or less dotted when in fluvial or lacustrine waters, disappear, leaving but few traces of his fresh-water garb. When taken in salt water it is found to be of increased size, upwards of twenty-five pounds, and is generally called by marketmen and anglers "the salmon-trout," which causes greater difficulty in an intelligent appreciation of the technical differences of the charr-trout and the salmon-trout. The numerous local and variant names for the same species of fish in different waters presents the greatest bar to the increase of popular knowledge of the fish fauna of American waters.

The cut-throat is an omnivorous feeder, but, like all species of the same family, is cleanly in his choice of food - he does not touch carrion of any description. Minnows, insects, worms of all kinds, grasshoppers, fresh meat, and above all the artificial fly, when properly and skilfully manipulated, is most attractive; for he is at all times, when the water is clear, a surface feeder, but is not particular as to coloration or form of the feathered lure presented to him. The angling tourist visiting the native waters of this fish, to be assured of success among the cut-throats, need only stock his fly book with the standard flies used in luring 
the Eastern brook trout. If he visits the Yellowstone or any of the large rivers containing this fish, it would be well, however, to have a fly rod of not less than seven or eight ounces, as the fish in such waters frequently attain a weight of six and seven pounds; the water gear used in the East for trout will answer every purpose on a cut-throat outing; at least such has been my experience.

This trout is not, I think, as game as either the red-spotted trout of the East, the rainbow, or the grayling, nor is it as choice a table fish as fontinalis. True, it is as muscular in its fight for freedom from the hook as the first-named fish, but its struggles are more brief, and unlike the rainbow and the grayling, it does not leap from the water on a slack line - a true test of the intelligence of a fish in its resources for escape.

The cut-throat spawns in the spring, sometimes as early as March, but usually in May and June. The nest is guarded by the male until the eggs are all deposited, which are then left on the bed, subject to the ravages of other fish, the batrachians, and larger water-beetles, which together destroy not less than ninety per cent of the eggs. Happily, the United States Fish Commission and those of many of the states have established hatcheries, 
from which the cut-throat is being distributed in the West and very generally in the Eastern states, particularly in New England, where they find a favorable habitat and are increasing in numbers and game qualities - a not unusual result among transplanted fish. When their new environment is adapted for them, they often, especially the brown trout and the rainbow, increase in average weight and develop traits of gameness they did not possess in their home waters.

There is another peculiar condition under which the cut-throat lives and thrives, that requires attention in this brief monograph of the fish. It has been reported from time to time that the angler could catch in the waters of the Yellowstone Park a trout from one pond, and by a mere swing of the rod cook the fish in the boiling water of an adjacent one, without unhooking his quarry. It has been discovered through the work of the United States Fish Commission and the researches of Dr. Jordan, that the waters of the geysers and other calcareous and silicious springs do not appear to be objectionable to fishes. In the Yellowstone Lake trout are especially abundant about the hot overflow from the Lake Geyser Basin. The hot water flows 
for a time on the surface, and trout may be taken immediately under these currents, and they have also been known to rise to a fly through a hot scalding surface. They also linger in the neighborhood of hot springs in the bottom of the lake. This is probably owing to the abundance of food in these waters, but the fact is evident that geyser water does not kill trout. The Hot River which drains the Mammoth Hot Springs flows into Gardner River. Trout abound at the mouth of this stream, and here, as in numerous other places in the Park, the much-reported practice of catching a trout in cold and scalding it in hot water is possible. These trout, however, are almost invariably infested with parasitic worms, some of them longer than the fish, causing it to become leaner and flatter than the healthy ones, and the sides and belly to show ridges and lumps. The flesh, also, is redder in the diseased fish, and the external color is likely to be dusky or brassy.

As will be seen in the schedule previously given, there are thirteen subspecies or varietal forms of the cut-throats (clarkii). Taking these up seriatim, we reach first the trout of the Yel- 
lowstone River (Salmo clarkii lewisi). This subspecies presents no marked differentiation from the type of the species above described, except that its body is somewhat more robust, with fewer spots on the belly: the red throat mark is always present and the scales are small. This fish is very abundant in the Yellowstone and its upper tributaries, and the river adjacent to and for miles above Livingstone, Montana, is a typical trout water, reminding the angler on Eastern streams of the broad reaches, pools, and "swims" of the Lower Beaverkill, Willowemoc, and Neversink trout rivers of Sullivan County, New York. The pools of the Yellowstone are not wadable, as a rule, but every inch of them can be reached and threaded with the flies from the outlying shores and shallows; and the trout are found often in the rapids, but more frequently at the foot of them, waiting for drifting and drowning insects or surface-washed food of a more substantial character. The angler has ample room for his back cast, and there are no overhanging branches to hold his feathers in mid-air. This fish takes the fly viciously, but contents itself with deep and long surges in its efforts to escape the hook.

There is another form of cut-throat which owns 
no popular name. It is evidently sui generis, and has increased the difficulty of exact classification in this conglomerate series of fishes, for it has no red on its lower jaw, or teeth on the root of its tongue. It is technically known as Salmo clarkii gibbsii, and its habitat is in the tributaries of the Columbia River between Shoshone Falls and the Cascade Range; and it has been also taken from the Des Chutes and other rivers, also by Dr. Evermann from Big Payette Lake, Idaho. It is also found in Wood River, near Ketchum, Idaho, where my rod certainly landed several specimens previously referred to as trout nondescripts. But if they are nameless wanderers in Western waters, they are the peers in game qualities of any of the trouts of that region. They fight harder and longer when hooked than any other species of the cut-throats for which I cast the flies.

The Rio Grande trout (Salmo clarkii spilurus) is more familiar to the anglers of the Middle West, particularly those resident in Colorado, with the exception of the Colorado River trout (pleuriticus), than any other species of the cutthroats, for spilurus appears in great numbers in the Upper Rio Grande, and is abundant in all 
the mountain streams of the state, ranging in habitat southward as far as the mountains of Chihuahua in Mexico. Its physical characteristics are pronounced: the body is four times longer than its depth; the head three and a half times shorter than the length of the body and it is heavy but short, the upper surface being considerably concaved or decurved; it has a large mouth, the upper jaw reaching backward beyond the eye, and the teeth on the roof of the mouth are in two series. The first dorsal fin is short in front, and the rear rays are long and high, the last being nearly two-thirds the height of the first one; similar proportions exist in the anal fin, the last ray being longer than the others. This fish has numerous round spots on the back, sides, and on the tail and fatty fins; on the body they are more profuse on or near the fleshy part of the tail (peduncle). It grows to a length of about thirty inches and is apparently identical with the Colorado River trout (Salmo clarkii pleuriticus). It differs, however, from that fish in that the scales are less crowded on the anterior part of the body and are longer. Its technical subspecific name is derived from two Greek words signifying "spotted tail." 
The Rio Grande trout is an exceptional game fish and a choice feeder; it takes the artificial fly greedily and fights hard under restraint, and in the opinion of a resident angler " is the best fish that swims in any waters of the earth and is only found in the cool and sparkling streams of the Rocky Mountains." We question if this ardent Waltonian has ever killed on a light rod the acrobatic rainbow, or the frisky "lady of the waters," the Michigan grayling; but be this as it may, the Rio Grande trout is one of the most game of the cut-throat series, and best of all, is not finicky in the matter of form and coloration of the feathers presented to him. 


\section{CHAPTER III}

SALMON-TROUTS CONTINUED-COLORADO RIVER TROUT - WAHA LAKE TROUT - GREENBACK TROUT - YELLOW-FIN TROUT-LAKE TAHOE OR TRUCKEE TROUT - TROUT OF LAKE WEBBERUTAH LAKE TROUT-SALMON TROUT OF LAKE SUTHERLAND - SPOTTED TROUT OF LAKE SUTHERLAND - LONG-HEADED TROUT OF LAKE CRESCENT.

While there are no great differences in physical characteristics between the Rio Grande and the Colorado River trouts, the latter appears to have attracted the attention of the anglers of that section to a greater extent. He is the objective of nearly all their outings, and his game qualities have been heralded in every sportsman's journal throughout the country. This trout is large, handsome, and extremely variable in coloration, with a red lateral band nearly always existent. In some instances the body is profusely spotted, occasionally with large spots, which are more numerous posteriorly, the head being almost entirely free from them; the lower fins are generally red, occasionally orange, and 
the scales are small. It is abundant throughout western Colorado, and southward as far as the clear mountain streams of Arizona, and specimens have been taken from still farther southern waters that are similar to those found in the Eagle and Gunnison rivers of Colorado. The technical name of the fish is Salmo clarkii pleuriticus, the subspecific being from a Greek word meaning "side," in allusion to the red lateral band.

The waters of Colorado are particularly adapted to trout and their lustiness of habit and increase. Dr. David S. Jordan, now president of the Leland Stanford Jr. University in California, was deputed in 1889, by the United States Fish Commissioner, to ascertain the general character of the streams of Colorado and their adaptability for the introduction of fish not found there. In his elaborate report Dr. Jordan thus writes of the waters of the state:-

"Most of the streams of Colorado rise in springs in or above the mountain meadows, many of them having their origin in banks of snow, which the clear weather of summer is not sufficient wholly to melt. These streams are clear and very cold. In their descent from the 



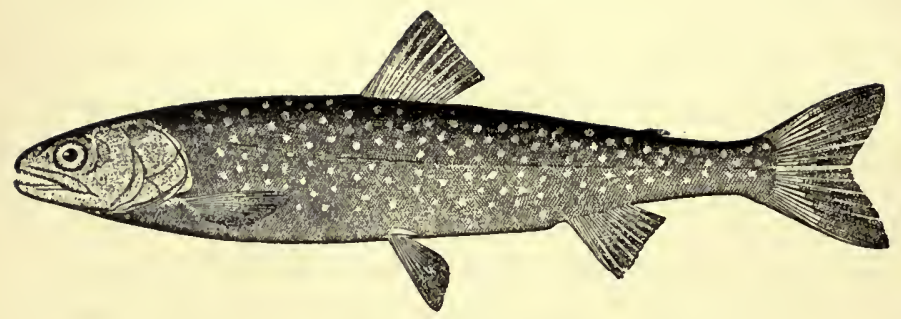

THE OQUASSA. OR BLUEBACK TROUT

Salvelinus oquassa

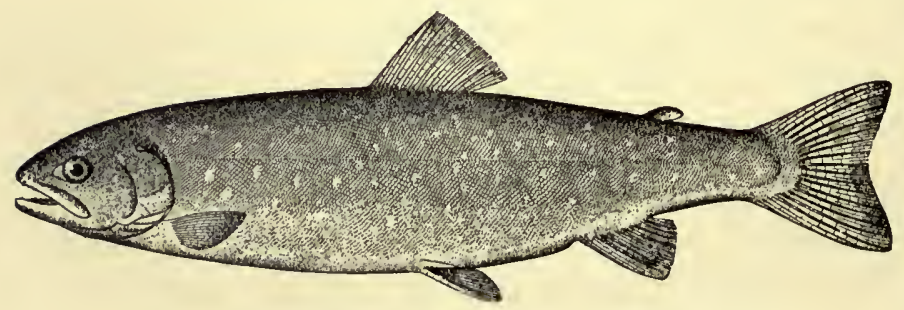

THE SUNAPEE TROUT, OR GOLDEN SAIBLING Salvelinus alpinus aureolus

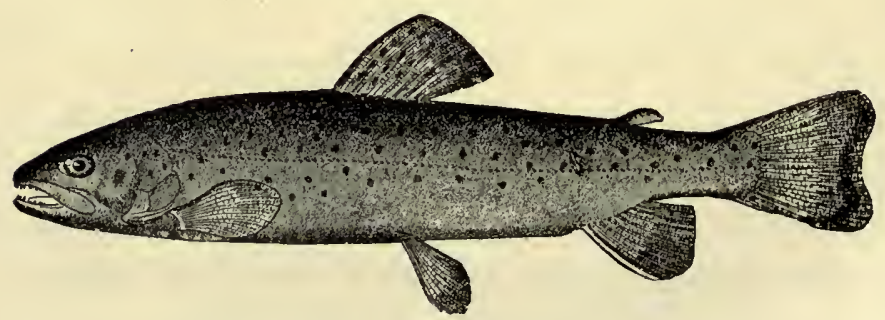

THE GERMAN, OR BROWN TROUT 
snow banks, they are brawling and turbulent, often so much so as to be unfit for fish life. In their course through the mountain meadows (very similar to the 'Alp pastures' of Switzerland) the streams are usually of gentle current, with many windings and with occasional deep holes beloved of trout. Lower down most of them pass to the valleys through deep cañons, some of them very deep and with many rapids."

With these facts before us, no surprise can arise when we find in Colorado at least two indigenous varietal forms of trout; and when it is noted that the land-locked salmon, the rainbow, and the Eastern red-spotted trouts (fontinalis) have been introduced into the waters of the state, the last two species named thriving vigorously, we can readily appreciate the ardor of pursuit and the increase of membership of the craft of anglers in this trout-gifted state.

The Colorado River trout grows to the exceptional weight of over nine pounds, several specimens of that size having been caught by Mr. Partello of the United States Army. The average weight, however, will not reach more than a pound, their size depending upon the area of the water from which they are taken. 
Their time of spawning is irregular; nominally it takes place in the spring, but frequently gravid females are found in the early days of August, although a large majority are through spawning by the middle of June.

This trout is an omnivorous feeder, taking indiscriminately whatever is thrown to him, chunks of meat, grasshoppers, worms, white grubs, and minnows, - but he has a weakness for insects, hence takes an artificial fly with avidity, particularly the Coachman, Black Hackle with a peacock body, the June Spinner, and the Black Prince. They take these imitations eagerly in the rifts, which they seem to prefer when feeding to the pools or deeper currents; July is the best month for fishing in all the waters of the state, from which a number of these fish have been taken by the United States Fish Commission to the hatchery at Wytheville, Virginia, for the purpose of stocking Eastern streams.

The Waha Lake trout (Salmo clarkii bouvieri) was first discovered by Captain Bendire, U.S.A., in Waha Lake, a small mountain pond, land-locked, in the state of Washington, to which it seems to be confined, as it has not been found in any other waters. It is singularly colored, with dark spots 
only on the back fins, and on the tail, upon which fin they are very profuse and small. The head is shorter and deeper, and the snout shorter and blunter, than those of other forms of the cut-throat trouts, and the tail fin is moderately forked: The anterior portion of the body is dusky bluish, not silvery, and there is a red blotch, very conspicuous, on the inner edges of the dentary bones. The habitat of this fish being restricted and secluded, but little is known of its angling qualities, yet like all other members of the genus, it will doubtless take the usual trout lures if presented to them properly.

The cut-throats are represented in the Upper Arkansas and South Platte rivers by the greenback trout (Salmo clarkii stomias, the subspecific title being from the Greek, signifying "bigmouthed "). It is abundant in the waters named, and in brooks and shallow places in lakes, but seldom, if ever, reaching the weight of a pound. It is closely allied to the other forms of clarkii, but the black spots are much larger, and are mainly located on the posterior part of the body; the head is broad and flat. Its flesh is deep red, and the general external coloration is deep green with a reddish tinge, sometimes extending on the 
sides. The subspecific name seems to be a misnomer, as the mouth of the fish is small, not large, as indicated in the Greek word. We know but little of this fish, its game qualities not having been described, nor does it appear that $\mathrm{W}$ altonians seek for it or take any interest in its habits or fighting qualities. Dr. Jordan, however, who made a study of the habits of stomias, writes:-

"It seldom exceeds three-quarters of a pound in weight, and is very common in the upper tributaries of the Arkansas River, and in Twin Lakes. It spawns in spring, in snow water if possible, and it will leave spring water to find snow water. In winter, however, they seek for warmer waters. It is said that when the winter breaks up, these trout are too blind to see bait. In color, the greenback is green or even almost black on the back. The lower fins and the throat are bright red, but there is not much trace of the red lateral band, and in some cases the black spots are ocellated with paler. At spawning time, in May and early June, the males have much red, but later on the sexes become similar. In specimens found about pools there is often much red even in summer."

The yellow-fin trout (Salmo clarkii macdonaldi) is supposed to be a varietal form of the Colorado 
River trout (pleuriticus) or descended from it. It certainly possesses many physical characteristics of that fish; the scales are about the same size, and the fin rays nearly alike in number, but the head and the gill covers are longer, and the two fishes vary greatly in coloration, that of the yellow-fin being a light olive with a broad shade of lemon-yellow along the sides, with no red on any part of the body except the crimson slash on the throat. On the posterior part of the body, and on the dorsal and tail fins, there is a profusion of small black dots giving the fish the appearance of having been strewn with the contents of a pepper castor; on the head and anterior parts of the body few or none of these spots are present. This is a large, handsome fish, growing to a weight of nine pounds (one specimen of thirteen pounds has been reported), and is abundant in Twin Lakes, Colorado, but is never found in streams. It delights to bask in the sun on the shallow gravel beds, and is seldom caught in the deeper water. They feed largely upon the young suckers which are numerous in the lake, and the suckers in turn destroy large quantities of the spawn of the yellow-fins. The flesh of this trout is paler than that in other forms and somewhat 
watery, hence it is not as good a table fish as its congeners of Colorado waters. Before they mate for spawning they take a trolling spoon or artificial fly very freely, as well as other lures, but just before spawning and during that period they refuse baits of any description.

One of the most interesting of this series of salmon-trouts is the Lake Tahoe, Truckee, or silver trout (Salmo clarkii tahoensis). It is easier recognized as a special varietal form than most of the other subspecies of the cut-throats, as the head is longer and more cone-shaped, and the spots are more individually unequal in size and arranged differently. Its other characteristic markings are: robustness of form, and greater depth of body than prevails in other cut-throats; large head; small eye; teeth on the roof of the mouth in two long series, alternating - and the teeth on the root of the tongue are distinct in a rather long series; large mouth, extending beyond the eye; rounded gill covers; caudal or tail fin shaped like a new moon, lunate, having a broad and rather shallow fork. The coloration is a dark green on the back, belly silvery, with a broad coppery shade on the sides and on the cheeks and gill covers. Instead of the usual red or crim- 
son slashes on the lower jaw, a yellowish hue prevails, and there are slightly conspicuous orange dashes between the branches of the mandible or under jaw. The fins are of an olive color, slightly reddish at or near the base, and the back from the snout to the tail is profusely covered with large black spots of unequal sizes; those on the top of the head and on the nape are large, and on the posterior part of the body run together forming oblong blotches; on the side of the head and body there are very few spots; the anal fin (on the belly near the tail) has upon it numerous round spots; the dorsal and tail fins are densely covered with oblong spots, smaller than those on the body; the second dorsal or fatty fin is also spotted. This fish grows to a weight of twentyfive or thirty pounds, and spawns in the depth of the lake.

I have entered more into detail as to the markings of this fish, than when describing other forms of the cut-throats, because it is probably sought for by greater numbers of anglers than any other fish of the Pacific slope waters. Being reached in a few hours from San Francisco, the resident anglers of that city make Lake Tahoe the Mecca of their outings, and no visiting angler 
rounds up his fishing tour unless he essays these big trout; the hotels at the lake are crowded all through the season, for the fish are large and numerous, growing, it is reported, to thirty pounds, although the average does not exceed two pounds.

There is another form of the Lake Tahoe cutthroat, known technically as Salmo clarkii henshawi, and locally as the "pogy" when mature, and as the "snipe" when young. It seldom grows larger than five or six pounds, and spawns in the streams. The coloration and other characteristics are very similar to those of the large form; the only striking differentiation being its smaller size, less compressed head, and diverse habits of spawning.

The method of fishing for Lake Tahoe trout is somewhat crude, at least it was a few years ago; but perhaps improvement has taken place in the use of lighter tackle, particularly in the water gear, the more general use of rods, and the discarding of handlines and heavy sinkers, which formed the favorite tackle for the capture of these large trout, both in trolling and in still fishing. In the former method there was generally attached to the outer end of the line a 
large spoon which was cone-shaped, having two wings, and a series of gangs of large hooks, entirely too large, as a rule; sometimes, however, a single hook or an eighteen-inch snood was used (the proper thing). The handline was also too heavy and coarse, and the local tackle was proven to be out of keeping with the size and game qualities of the fish, from the fact that several visiting anglers have had more pleasure and taken as many trout with comparatively light rods, reels, and small spoons, as were caught by the guides and local anglers. I have not heard that these trout will rise to an artificial cast of flies, their habitat being in the deep water, yet, in following their tribal instinct, they will naturally come into relatively shallow water preparatory to spawning, and at such times, if the law is open and the conscience of the angler permits, they could doubtless be lured with the feathers.

But if the Lake Tahoe trout taboo the fly, there is within easy carriage distance of the lake a grand water (Webber Lake) for the fly fisherman, where the trout are surface feeders and great fighters. It is closely allied to the Lake Tahoe trout, which I have as yet failed to fish, but it is difficult to believe that trout should so radi- 
cally alter their habits as to become habitual surface feeders when the type of the species, inhabiting waters but a few miles distant, seldom, if ever, come to the top of the water. Instances have been known, however, when these individual traits have been developed in trout, but the lakes in which they lived were often widely separated. I am rather inclined to believe that the trout of Webber Lake are an entirely different subspecies. Be this theory wrong or right, the fact remains that the fish of Webber Lake rise freely to the fly and fight bravely, and the angling tourist visiting Lake Tahoe should not fail to see the sister lake, and for his information I state that the Black Hackle, red-bodied Brown Hackles, and rather sombre-colored wing flies are the most attractive. Strange to note, these fish which spawn in streams do not rise well to the Coachman or any other flies dressed with light wings.

The Lake Tahoe trout is found in the following-named lakes and rivers: Lakes Tahoe, Pyramid, Webber, Donner, Independence, and in the rivers Truckee, Humboldt, Carson, and in most of the streams of the eastern slope of the Sierra Nevada. They also inhabit the head waters of the Feather River, west of the Sierra 
Nevada, into which they may have been introduced.

The trout of Utah Lake (Salmo clarkii virginalis, subspecific name from the Latin, "like a virgin ") is a striking illustration of the adaptability of fish to widely different chemical conditions of water. This trout not only lives in an alkaline lake, but thrives there, growing to a weight of twelve or more pounds; its back is covered with small black spots from head to the fleshy part of the tail, where they are not so numerous, and the scales are slightly larger than those of the greenback and Rio Grande trouts. It is found in the lakes and streams in the Wasatch Range, particularly in Bear, Provo, Jordan, and Sevier rivers and in Utah Lake. On the trout of the last-named waters the dark spots are few and small and are located almost entirely on the back; they are also paler in color than is general with fish of the same species found in the streams; but, like all forms of the cut-throat series, different colorations may be found in nearly every fish examined. The Utah Lake trout is said to be a good fighter on the rod, and is highly prized as an edible fish in the sections of its habitat. 
Within the last few years two subspecies of the cut-throat trouts have been discovered in Lake Sutherland, in the state of Washington; also a distinct species of the salmon-trouts in Crescent Lake of the same state. As neither of these fish has been sought or taken by any one except an occasional angling tourist, and by their discoverer, Professor Meek, an intelligent, practical, and diligent ichthyologist, whose interest and zeal in his science does not blunt his love of angling, I am dependent upon him for the annexed notes of their characteristics, which ere many years will doubtless become as familiar to the anglers of the Pacific slope as the common cut-throat or the rainbow.

The salmon-trout of Lake Sutherland (Salmo clarkii declivifrons) resembles very much the blueback trout of Lake Crescent, described on a subsequent page, and is easily recognized, according to the authority of Professor Elliot, by the sharply curved upper outline of the fore part of the body, by the dark blue patch on the cheek, and by the gape of the mouth, which is nearly horizontal, more so than in any other trout. Professor Meek states that it is a game fish, "takes the fly and leaps out of the water." 


\section{Lake Crescent Trout}

The other cut-throat, popularly called "the spotted trout" (Salmo clarkii jordana), is also found in Lake Sutherland, and may be distinguished from its congener of the same waters, the salmon-trout, by the orange or orange-red color of its fins, by the red on the jaw, and "the number and blackness of its spots and the darker back." It is one of the most active of trouts, and repeatedly and rapidly leaps after taking the fly.

The new species of salmon-trout found in Lake Crescent, Washington (Salmo bathocetor), can be distinguished from others of its genus of adjacent habitat, primarily by its long nose and the absence of the red slash on the lower jaw. It is also more slender, and the dentition is much stronger than obtains in the other varietal forms living in Lakes Sutherland and Crescent. It lives in deep water, in some places over seven hundred feet, and does not come to the surface at any season of the year. The few that have been caught were taken on set lines within a foot of the bottom at a depth of about two hundred feet. It is known locally as "the long-headed trout." 


\section{CHAPTER IV}

SALMON-TROUTS CONTINUED - THE STEELHEAD SERIES - TYPICAL STEELHEAD - KAMLOOPS TROUT - BLUEBACK TROUT OF LAKE CRESCENT, WASHINGTON - SPECKLED TROUT OF LAKE CRESCENT, WASHINGTON

WE now reach the steelhead series of salmontrouts of which there are one species and three subspecific forms, the type being commonly known on the Pacific slope as the steelhead, hardhead, and salmon-trout, and scientifically as Salmo gairdneri. It is a large sea-trout growing to weight of twenty pounds or more, and is migratory like the salmon, ascending rivers to spawn many hundreds of miles into the state of Idaho and into other sections. I have taken them from the Snake River of southern Idaho weighing three to five pounds; in those waters they spawn in the early spring, and are found in the lower parts of rivers in a spent condition when the usual spring run of the salmon commences. For a long time the steelhead and the rainbow were, owing to the close 


\section{Steelbead Trout}

intergradation of the two species, considered one and the same fish; but the investigations of Dr. Gilbert in the Lower Columbia River convinced him that both the young and the old steelheads are distinct from the cut-throats and the rainbows. It is proper to state, however, that two other ichthyologists have placed on record that the Columbia River form of the typical steelhead seems to pass into the rainbow southward, and into Kamloops northward, while in the Lower Snake River of Idaho it appears to intergrade with the cutthroats. With these confusing data before them, we are not surprised at the hesitation of the scientist to permanently determine the classification of these fishes, nor at the angling layman halting at the cross-roads of science.

The steelhead trout has scales relatively large, near the size of those on the Utah Lake trout, but on specimens taken from the Lower Columbia the scales seem to be more or less small and crowded. The body is relatively stout, but not deep, and the fleshy part of the tail is very thick; the head is short, rather slender and smaller in females, while the jaws in the males are somewhat prolonged. The upper jaw is narrow, the small eye of the fish being located above and 
about the middle of it; the teeth are small, those on the roof of the mouth are in two long, alternating series; the anterior gill cover is rather wide and the others moderate in size. The tail is wide, and on the young fish is somewhat forked; in the adult it looks as if cut with a blunt pair of shears. The flesh is pale, and the general external coloration is an olive-green on the back and silvery on the belly. In the fresh sea-run fish taken in the salmon traps of Upper Puget Sound, I observed that a deep blue tinge was always present on the back, and on the head, back, upper fins, and tails were more or less black spots, but the belly was usually free from them. Both sexes in the spring have a broad flesh-colored median band, and there is a deep, mellow red on the gill covers, and this coloration is generally retained throughout the year. The fins are not tinged with red, and no color slashes of crimson are present on the lower jaw.

The steelhead inhabits coastwise streams from British Columbia south to Santa Barbara County, California, and those west of Sierra Nevada and the Cascade Range. It is very abundant in the Lower Columbia, the Russian, and Klamath rivers. In edible qualities it is about on a par 
with the other salmonoids, which with the exception of the Pacific salmon (Oncorhyncus) and the golden trout of the Mt. Whitney streams, are inferior, I think, as table fish, to those of the same family with a habitat east of the Alleghany Mountains.

But if they are inferior as food fishes, the steelheads certainly possess all the game qualities of our Eastern trouts, and their large size, when taken in the lower estuaries and at the mouths of rivers, adds to the zest of capture. They are fly-takers when in the streams, and when found on shallow ledges of rocks and on the bars in the lower waters. On taking a natural bait the steelhead is apt to surge deep and strong, but when fastened on the artificial feathers, for which he rises eagerly, is an acrobat, leaping repeatedly from the water. These aërial flights naturally lead the angler to believe that he is closely allied to the rainbow, the only trout living in waters west of the Rocky Mountains, with the exception of the stream steelhead, that rose to my flies and leaped frantically into the air.

Like most of the salmonoids of the Pacific coast this fish is rich in local nomenclature; the Russians call it somka, the Kamchatkans, 
mykiss, the Indians, humaana, to which Americans have added steelhead, hardhead, and salmontrout.

During the last decade ichthyic research has been very active in the waters of the Pacific slope, and in addition to radical changes in the technical nomenclature of the salmon-trouts, two new species have come to light, and one of the charr-trouts of Eastern waters hitherto strange to science has been differentiated and classified: these new species will be described on subsequent pages.

For many years there was known but one subspecific form of the steelhead series, the Kamloops trout (Salmo gairdneri kamloops). This is a fine large fish, doubtless intergrading with the typical steelhead, but differing from it in habits, coloration, and in form. It is landlocked, and, so far as is known of its habitat, is confined to the lakes of British Columbia, particularly lakes Kamloop, Okanogan, Kootenay, and other lakes tributary to the Fraser River or to the Upper Columbia. In form it is slender and graceful, while the type of the species is rather stout, somewhat deep, with a thick fleshy tail formation.

(By "fleshy tail" is meant, not the fin, but the 



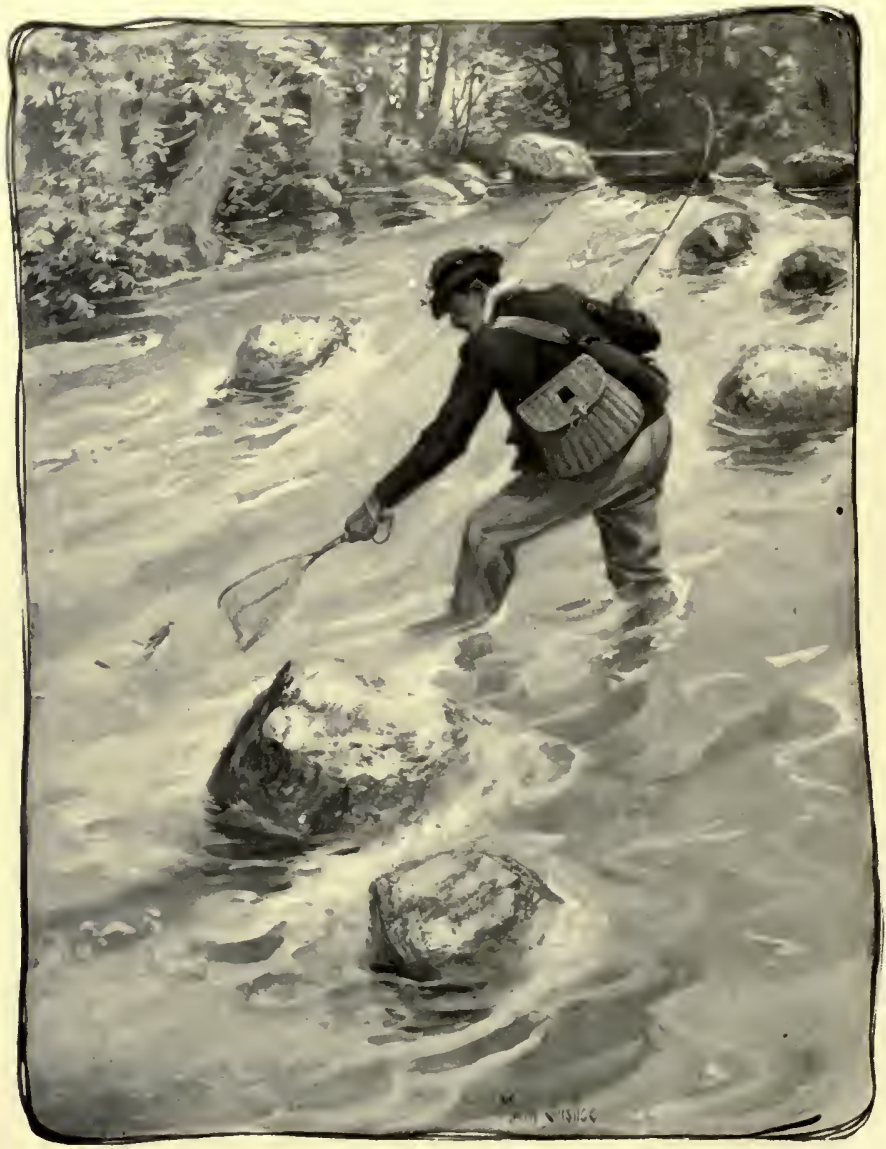

THE CRUCIAL MOMENT 
peduncle, or that part in many fishes which is finless, usually between the dorsal, caudal, or anal fins; in the trout it is the posterior part of the body situated between and below the second dorsal or fatty fin and the tail or caudal fin.)

The Kamloops trout has a large eye, a rounded snout, and a rather large mouth, the upper jaw extending backward beyond the eye; the first dorsal fin is somewhat low, but the anal fin (next to the tail fin on the belly) is larger than usual in trouts, and the caudal fin is broad and strikingly forked. The coloration is much brighter than in the typical species, being very silvery below the lateral line and with few spots; on the back a darkish olive prevails, and when the fish is freshly taken from the water, on the middle of the sides a broad band of light rose-pink is present, covering about one-third of the entire depth of the fish. Spots of the size of pinheads are irregularly scattered over the back, being more numerous posteriorly, with only a few faint ones on the upper part of the head; there are also numerous small black spots on the dorsal and anal fins, similar to those on the back, but more distinct.

We have no detailed account of the actions of 
the Kamloops trout when restrained by the rod, but there is no question as to its game qualities, for its environment, pedigree, and structure indicate the possession of these traits; moreover, being landlocked and seldom growing beyond sixteen or seventeen inches in length, the average weight not exceeding a pound, and spawning in the small confluents of the lakes of its habitat, no doubt can exist as to its rising well to the surface-fly and fighting bravely for freedom.

Within a comparatively few years, Admiral L. A. Beardslee, U.S.N., an ardent angler and close observer, while stationed in command of the fleet at Port Angeles, Washington, found two new species of salmon-trouts, each of the steelhead type. Both of these fish were living in Crescent Lake, Washington, and one, the blueback trout (Salmo gairdneri beardsleei), was caught in deep water, from thirty to fifty feet, and Admiral Beardslee reports that when landed it was found "puffed up with air." They fight hard until brought to the surface, when they give up at once and are easily netted or gaffed. They have not been as yet taken with artificial flies, the prevailing lure being a large spoon, 
with a heavy sinker attached to the line, the spoon spinning near the bottom of the lake. The Beardslee trout from the description given by Mr. George E. Mitchell of Port Angeles, is certainly a handsome fish. He states:-

"On the back there is a deep, dark blue ultramarine color of a peculiar transparency, dotted with small round black spots from the size of a pinhead to slightly larger; the two fins on the back are dusky in color, with dots also, but transparent; the tail fin is of the same coloration, and the pectoral (breast fins) and belly fins are white and sometimes faintly tinged with a pinkish hue on the edges. Looking at the fish sideways, the scales are iridescent, the red flash predominating. The head has very much the polish of mother-of-pearl around the lower jaws, red and pale blue colors predominating."

Mr. Mitchell might have added that the pale pink band of the lateral line enhanced the beauty of the coloration of the fish, which has no red slashes under the lower jaw, as prevails usually in the cut-throat species. The most prominent differences in the typical steelhead and the trout of Lake Crescent, independently of that of coloration, which is pronounced, is in the scales, those 
of the Beardslee trout being larger, and the body is cleaner built and less stout.

The third and final subspecies of the steelheads was also found in Lake Crescent, Washington, and is known as "the speckled trout of Lake Crescent" (Salmo gairdneri crescentis). It is more slender than the Beardslee trout, and can be distinguished from it by the yellowish red spots on the lower fins, the former having only small black spots on the caudal and dorsal fins. The speckled trout may also be known on sight by a large black blotch on the cheek, below the eye, and behind the premaxillary (bones forming front portions of the upper jaw). I have no personal knowledge of the fighting qualities of this Lake Crescent trout, but from the sparse reports received, would judge it to be an active game fish with the leaping traits of the other steelhead forms. 


\section{CHAPTER V}

SALMON-TROUTS CONTINUED - THE RAINBOW SERIES - RAINBOW OR COAST RANGE TROUT - BROOK TROUT OF WESTERN OREGON - MCCLOUD RIVER (CALIFORNIA) RAINBOW - KERN RIVER TROUT NO-SHEE TROUT - GOLDEN TROUT OF MT. WHITNEY (CALIFORNIA) - BROWN OR GERMAN TROUT - LOCK LEVEN TROUT

Following the latest approved system of gradation in classification of the salmon-trouts, we now reach the rainbow series, which, in my opinion, are the typical game fishes of the salmon family with the exception possibly of the Atlantic seasalmon and the wannanish or ouananiche of the Lake St. John region of Quebec; and many anglers believe that "inch for inch and pound for pound" the rainbow is their equal in fighting qualities when found in streams of moderate size and depth like the Au Sable rivers of Michigan and the waters of Essex County, New York. The rainbow is, without doubt, one of the most muscular and resourceful of fishes for its size, rising freely to the artificial fly, leaping on a slack line, 
250 The Trouts of America

and fighting literally to the death. They made on my rod in the wild waters of the state of Washington as sturdy a fight as the steelhead, and a greater one than the cut-throat or the Montana grayling, coming frequently into the air and making longer and stronger surges than the brook beauty of our Eastern mountain streams.

I caught the rainbow on similar flies as those that lure the black-spotted trouts and the Montana grayling. They were apparently more indifferent to shades of color and form of dressings than either of the last two fishes named, and were equally numerous and eager for the feathers in all conditions of the stream - the quiet pools, the gentle rifts or rushing rapids, the long stretches of either still or foaming reaches; the eddies below outjutting rocks, or the swift and narrow waters between them, all yielded "the redsides," as they are often called on the Pacific slope. It was also noted that they were much quicker than other trouts in their movements, particularly in seeking the shelter of shelving rocks, reminding the angler, when first hooked, somewhat of the mangrove snapper of the Gulf waters, but under the restraining line they come 
grandly from the water, leaping sometimes over two feet into the air.

Strange as it may appear, the rainbow when planted in Eastern waters suitable for them, exhibit greater game qualities than is shown in their native habitat. This was the unanimous opinion of every angler with whom I fished for rainbow in Michigan and in Keene Valley, New York; and these rodsters had cast the feathers for the indigenous fish of the streams of the state of Washington and other sections. In Eastern waters, the rainbow appear to have acquired increased strength and certainly greater leaping traits, but this improvement in size and fighting quality is not unusual in transplanted fish. The introduced black bass from Western waters grows larger in Eastern lakes, and holds its own, when on the hook, with the parent fish in waters west of the Alleghanies. The abhorrent carp brought from Germany grows larger and more rapidly in our Southern waters, while he increases our repugnance to his flesh as food the more we see of him. The imported brown or German trout, which is rapidly becoming the butcher of our mountain brook beauties (fontinalis), bids fair to grow to the inert bulk of a 
Daniel Lambert among fishes, as it certainly is the largest and tamest fighter of our fresh-water salmonoids.

The rainbow is the hardiest of the salmontrouts, for it will thrive in water of a higher temperature than is suitable for other species, and does not appear to be afflicted with the ordinary diseases of fish to the extent that other species are. Fungus is not apt to ensue when the skin of the rainbow is bruised; this is, doubtless, owing to its active habits in foraging for food, as it seeks all sections and conditions of the stream, though loving best the highly aërated waters of a rapid current.

Although a gourmand in its appetite, it is cleanly in feeding, liking best the live minnow or the insect struggling for life on the surface; a swimming grasshopper is irresistible, and no fish rises so freely to a cast of artificial flies.

The differentiation between the rainbow and the steelhead lies apparently and solely in the scales; those on the latter being always smaller than in the typical "red-sides." Many intelligent and observant anglers believe that the young rainbows, so called, hatched in the brooks from spawn of the steelhead, remain in the mountain streams 



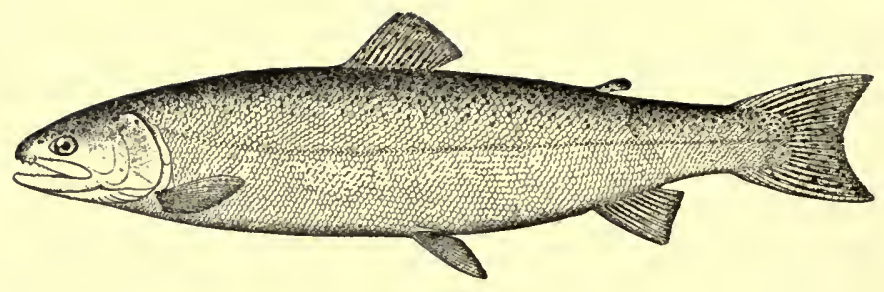

THE STEELHEAD TROUT

Salmo gairdneri
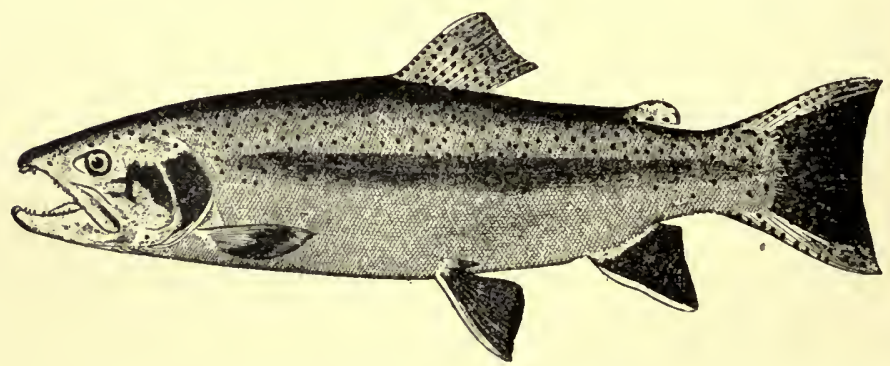

THE RAINBOW TROUT

Salmo irideus

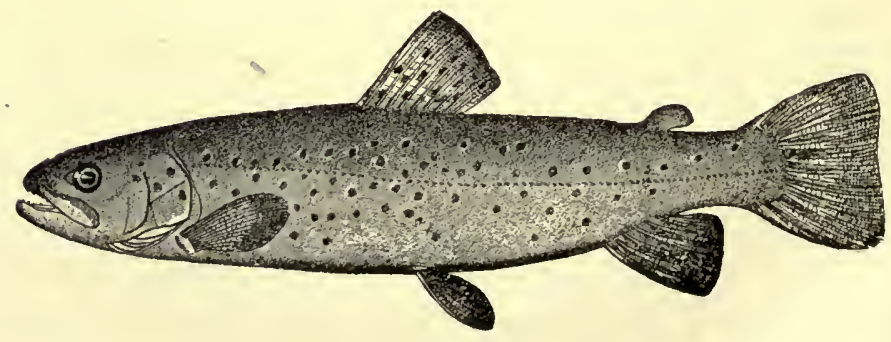

THE LOCK LEVIN TROUT

Salmo levinensis 
from six months to three years, going down to the sea with the high waters of the spring, after which they return to the streams to spawn as typical steelheads. Those that are landlocked or do not descend to the sea remain rainbow all their lives. Be this angling theory correct or not so, the only scientific rebuttal of it is the fact that the scales are smaller in the steelheads than they are in the rainbow, with a few other minor differences.

There are one species and five subspecies of the rainbows, the typical form being popularly known as the rainbow or Coast Range trout (Salmo irideus, specific name from the Latin, "a rainbow"). It is a large, robust, short, and deep fish, growing to a weight of thirteen pounds in the Williamson River, and up to thirty pounds when sea-run. The head is short, somewhat convex, and "obtusely ridged above"; mouth slightly smaller than in other trouts, and the eyes are somewhat larger; the teeth on the roof of the mouth are in two irregular series; the tail fin is slightly forked, the body, sides, and ventral fins irregularly but profusely marked with black spots, those on the tail being smaller than those on the body and on other fins. The coloration is bluish 


\section{4 \\ The Trouts of America}

above and whitish on the sides, which also, in both sexes, have a broad lateral band with reddish blotches, the sea-run specimens being plain silvery.

If an angler chances to catch a rainbow in Eastern waters, it will probably be where the Eastern brook trout is also found, and the "redsides" can easily be distinguished from it by the lateral band, more or less reddish, always on the sides of both sexes, and by the presence of numerous black irregular spots located on the body, head, and fins; those on the caudal fin being somewhat smaller than the spots elsewhere. The brook trout (fontinalis) has red spots; the rainbows do not have them. In this connection it may also be well to state that if the Eastern angler should chance to hook a German or brown trout, or a Lock Leven, both of which are introduced salmon-trouts, he will know the German form by its almost square tail, looking as if it was cut in a direct line by a sharp knife; it may also be recognized by its large scales visible clearly to the eye, and by the big red spots, the largest of which are just above the lateral line in an almost straight row. The Lock Leven trout may be known by its deep red flesh, and by the absence of red spots, which do not appear until the fish is 
three or four years old, and then are faint in color.

The habitat of the rainbow trouts is in the mountain streams of the Pacific coast, the type of the species being found in the brooks of the Coast Range, in California, from the Klamath River to San Luis Rey. So popular, however, is this fish, not only among anglers but with fish culturists, that it has been very generally introduced not alone in the Eastern states, but also in the waters of those states between the Alleghany Range and the Rocky Mountains. The United States Fish Commission has sent to England shipments of the eggs of the rainbow which have been successfully hatched. With the usual conservatism of Englishmen, however, the anglers of that country hesitate to place rainbow in waters inhabited by the native brown trout, than which the rainbow is vastly superior both as an edible and as a rod fish.

Following the usual classification, "the brook trout of western Oregon " (Salmo irideus masoni) is the most prominent of the five subspecific forms into which the species have been divided. It is the common brook trout of the Lower Columbia and of the coastwise streams of Oregon 
and Washington, and is very similar to the typical species (irideus). It is also the fish by which Dr. Gilbert differentiated the rainbows from the steelheads and the cut-throats; the size of the scales, as before stated, being the basis of the Doctor's conclusions. Certainly it is less slender than the cut-throat, and the snout is more rounded, there is no red blotch on the lower jaw, and no teeth at the base of the tongue; again, it seldom grows larger than a pound in weight. Jordan and Evermann state that this fish "apparently merges into the ordinary rainbow southward, if indeed the two forms are distinguishable. We know of no diagnostic character, but further comparison is needed."

This fish is the one sought after by the enthusiastic anglers of Seattle and Tacoma, and I am told it rises fiercely to the artificial fly, without any peculiar preference for form or color; but doubtless there are anglers in the cities named who are ready to "swear by" a combination of colors that represent no living thing on earth, in the air, or in the water.

The "McCloud River rainbow trout" (Salmo irideus shasta, the subspecific from Mt. Shasta, California) is of peculiar interest, as it was with 
this form of the rainbow trouts that the waters of the Eastern and Middle Western states were stocked, the first shipment from the McCloud River occurring in 1870 . Thus we have had the rainbow in the East over thirty-one years, and while many anglers and fish culturists are disposed to believe that the plant has been a failure, particularly as a food supply, other rodsters who have essayed this fish in waters adapted to it, are inclined to place it above all other trouts in game qualities. True, many failures have occurred when the fish has been placed in unsuitable lakes or streams, especially where easy access to deep water or to the sea occurs. It is by nature a sea-running fish, but it will not, or rather does not, go down to salt water when living in streams several hundred miles from the ocean although a free course lies before it. In this respect it resembles closely the habit of our Eastern charr, the red-spotted form, - which always visits the salt water when living in short coastwise streams, the mouths of which flow into the estuaries or bays, as occurs on Long Island and in several of the Eastern states, Massachusetts particularly.

For many years the subject of the original habitat of the salmon - whether in the ocean or 
in fresh waters - has been agitated and discussed by ichthyologists and fishermen. Does not this trait of the salmon-trouts and charrtrouts of going to salt water, wherever easily accessible, throw some light on the subject? It seems to be equally instinctive with all salmonoids to seek the sea after the spawning season is over, as it is for them to seek the cold upper waters to spawn, those habitually living in landlocked lakes or inland fluvial waters distant from salt water, having naturally lost their sea-going instinct from its long disuse.

It is this species of rainbow by which the anglers living east of the Pacific slope must judge of the game and edible qualities of the species; and as it thrives in many waters distant from its native habitat, we are not lacking data upon which to form a correct judgment. This fish is somewhat erratic in its likes and dislikes of certain waters, particularly those of the Atlantic east of the Alleghanies. We find it thriving beyond the Mississippi as far west as the Rocky Mountains, where it has been planted very generally, and the Waltonians are one in praise of its acrobatic and other game traits. The same may be said of this subspecies wher- 
ever it has been introduced in the Western and Northwestern states lying between the Mississippi River and the Alleghany Mountains. I have taken them in Michigan and found them superior to any other fish of similar size in any water. East of the Alleghanies there are some waters in which they do not thrive, or disappear, from some cause, entirely. On the other hand, there are streams, particularly in northern New York, where they grow in vigor of muscle beyond the limit of gameness shown in the parent fish of the McCloud River. Again, the mountain streams of western North Carolina are peculiarly adapted to them, and they grow therein to a large size and great fighting qualities; in New England waters, where they have been recently introduced, they are thriving well and yielding good sport on the rod.

It would seem superfluous to describe the markings and coloration of the Shasta rainbow, for the broad reddish lateral band should be a sign manual on sight; but the angler must remember that the cut-throat and steelhead trouts are being very generally introduced into waters east of the Sierra Nevadas, and that these fish also display the same markings on the sides, and may, 
in some waters, be confused with the rainbow. Hence, the following detailed description of structure and coloration of the Shasta is required :-

The body is nearly four times its depth, and the head is of the same proportion to the length of the body; in the first dorsal and anal fins will be found eleven rays, and the tail fin is more deeply forked than in the cut-throat, while the steelhead has a truncate or nearly square tail fin; the scales are larger than in the other two species named, and the eye is larger than in the steelhead, the mouth moderate in size. The coloration is bluish on the back and silvery on the sides, and all over the head, fins, and body above the median line black spots appear, the belly being nearly free from them. (The cut-throat has but few spots on the head, with deep red fins, and the steelhead is olive-green on the back and has no red on the lower jaw.) The fins seldom show a red tinge, but there is always present in both sexes of the Shasta trout the broad red lateral band and blotches, and to render identification more difficult and confusing there is usually a dash of red on the under jaw, similar to that shown under the mandible of the cut-throat, which, unfortunately 
and most perplexingly to the angler-naturalist, is not always present on the last-named fish.

The Shasta rainbow will rise freely to any of the standard trout flies, and as it grows to a stream weight of five or six pounds, it yields exceptional sport, particularly in waters, where it is new to the angler's rod. The dressing of the feathers, which it prefers when tied on No. Io Sproat hooks, are those of the March Brown, Coachman, and Brown Hackle used respectively as tail or end flies and first and second droppers.

The habitat of this trout is in the streams of the Sierra Nevada, from Mt. Shasta southward, but it is best known in the McCloud River, where the United States Fish Commission maintains a hatchery for trouts and the quinnat salmon. It is very abundant, and subject to many variations in form and color in its native streams, but not to so great an extent in waters to which it has been transplanted. The limit of its range southward is not known, and it may be that it intergrades with other forms of the rainbows in middle and southern California.

The Kern River trout (Salmo irideus gilberti) is one of peculiar interest from the fact that it has been found in no other water, and particularly 
from its size and the grandeur of its environment, the river coursing through a cañon of great depth, with the mountain sides on the west bank rising nearly perpendicular some thousands of feet. Adown its course the stream rushes wildly over a series of broken rocks, sand bars, cascades, and gigantic trunks of fallen juniper trees, and then subsiding, here and there, into deep pools. The trout may be found in all the varied conditions of the stream, and as they reach a weight of about eight pounds, the pleasure of catching them on a light rod and a dancing fly in such surroundings is incomparable, but to reach their home waters is somewhat of an arduous, certainly a lengthy, journey. My recent visit to the Kern River entailed a buckboard ride of sixty miles from Visalia, California, and a muleback straddle from Mineral King, of three days, over mountain ranges with narrow trails and precipitous sides, and rattlesnakes startling the mule every few hundred feet. Our party of six averaged a snake to a man each day of the trip, the revolver fired from the back of our mules being the destroyer. The Kern River country is the natural and densely populated home of the rattlers. 



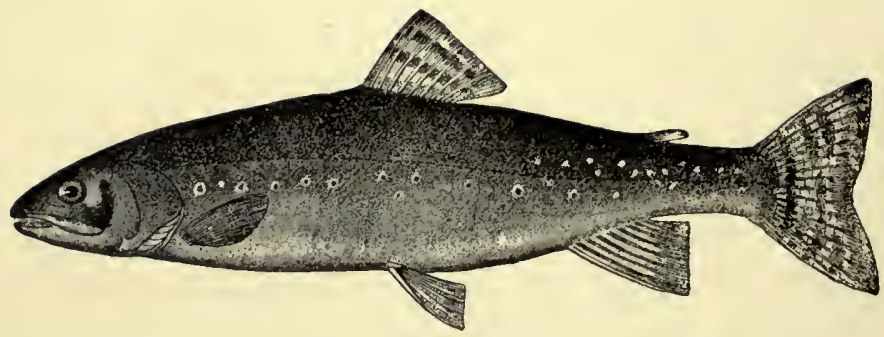

THE DUBLIN POND TROUT

Salvelinus fontinalis agassizit

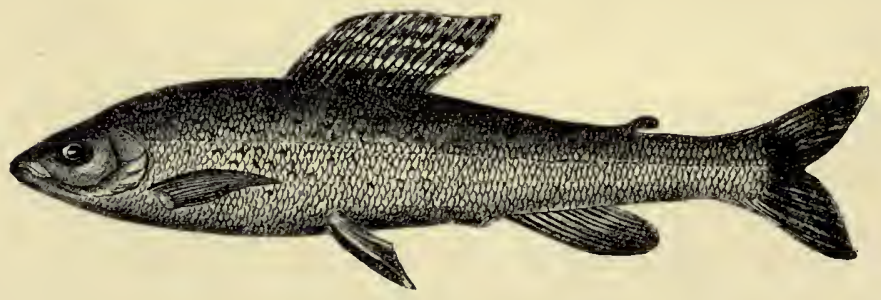

THE MONTANA GRAYLING 
The trout in Kern River is very similar in its markings and coloration to the McCloud River or Shasta trout; the scales, however, are smaller, being about equal in size to those on the typical cut-throat; sides and body profusely spotted, and the old fish have more or less orange between the branches of the lower jaw, which marking is faint or entirely wanting in the young fish. The characteristic red lateral band is present at all ages.

These fishes are very game, taking the fly on the surface and fighting hard by deep and long surges, a five-pounder taxing tackle and skill to net. None of them jumped out of water when hooked by me, but some anglers assert that these fish always come into the air when restrained by a springing rod, and from the fact that they are rainbows, the typical fish of this species always jumping freely, I am disposed to think that my experience was unusual, and that the fish were not in a leaping humor during my three days' outing on Kern River. This leads me to condone the sometimes liberal statements made by anglers as to the "how, when, and where" they killed such and such fish, and the peculiar antics the fins displayed before they were 
creeled. Certainly fish as well as fishermen have their "off days." But of one fact I am sure, the Kern River trout will, when in a feeding humor, take any fly that lures the charrs of Eastern waters.

In the upper Sacramento River will be found the "Nissuee," or, as the Indians call it, the "Noshee" trout (Salmo irideus stonei), which is abundant about eight or ten miles above the United States hatchery at Baird, California. It is distinguished by its large size, specimens having been taken weighing twelve pounds; by its small scales and fewer teeth - those on the roof of the mouth consisting of a single zigzag series. The upper parts of the body are of a plain greenish color; the black spots are few in number confined chiefly to the posterior part of the body, and on the back and tail fins (including the small adipose or fatty fin) they are small and sparsely distributed. This fish is said to rise freely to the artificial fly.

The Kern River trout is believed by many ichthyologists to be an intermediate grade between the rainbow, the steelhead, and the cutthroat, and so nearly halfway between that it cannot be said which species it is descended from. 
The "No-shee" trout, now under consideration, is reputed to be, by the same authorities, an intermediate between the Kern River trout and the McCloud River trout, the latter being slightly different in appearance from the regular rainbow trout. Just here it seems proper to give the basis of specific classification, accepted by fish savants:

"If one kind of fish and all known variations of it possess certain characteristics, and another kind and all its known variations have other distinct characteristics, each will be called a species and receive a scientific name."

In connection with the above lucid explanation of specific classification, it is also stated: "That when new variations of each species are found with the variations approaching each other, it will become more difficult to say where in the scale each species ends and what the characteristics of each species are. The more numerous these links between species and the more complete the scale between them, the more difficult it becomes to say to what species a variety belongs. The species become merged into one, and all varieties must be considered as one species. This is what has happened to the cut- 
throat and the rainbow trouts. These fishes are connecting links halfway between, going to show that the different species of American trouts, apparently distinct and widely separated and isolated geographically, are but nature's variations of a common stock, with links connecting them all."

These conclusions of the ichthyologists simply confirm those of the angler-naturalists who have grown gray in observing closely the habits and markings of fish when angling for them in their native waters; and it may be added that coloration, hitherto ignored as a factor in classification by the scientists, seems to have much to do in the identification, as distinct forms, of the salmontrouts of the Pacific slope.

The fifth and final subspecies of our native rainbow trout series is "the golden trout of $\mathrm{Mt}$. Whitney," California. (Salmo irideus agua bonita, the subspecific name, translated literally, is "beautiful water," the name, of a cascade on Volcano Creek, near which this trout abounds.) This fish has the most beautiful coloration of any of the salmon-trouts, and it is appropriately called the "golden trout," for a golden or orange tinge of different depths of color may be seen on all parts 
of the body, on the gill covers, and on the breast and anal fins. The popular name of this fish, "golden trout," should not lead to its confusion with the Sunapee Lake trout, which also has the common name of "golden trout"; the latter, fortunately, is a charr, and although a handsome fish, it does not have the mellow richness of color as is shown on the salmon-trout of Mt. Whitney. A more detailed description of its coloration is necessary to get even a partial conception of its beauty.

Olive prevails above the lateral line, and light golden hues more or less deep on the sides and belly; on the middle of the body, and along the lateral line there is a deep scarlet stripe, broadest under the dorsal and narrowing at either end, but not reaching the head or the base of the tail fin; on the middle line of the belly there is a broad scarlet band reaching from the chin to anal fin, which is equally bright in its entire length, with a fainter shade along the lower side from the anal fin to tip of caudal. There is no crimson slash on the throat, and the dark spots, large and well marked, are seen on the posterior part of the body, and on the tail fin; these spots are smaller, but also well marked on the dorsal fin, and a few 
smaller ones are scattered along forward to the head in some specimens, but not in others. The fins are variously and beautifully colored. On the upper angle of the first dorsal a yellowish white prevails, edged by a dark oblique streak, while the rest of the fin is light olive in color with four or five rows of small black spots. The pectoral or breast fins are of light orange, the ventrals deep orange with a faint blackish tip, the anterior edge conspicuously and abruptly white as in the fontinalis. The anal fin is dusky orange, the tips of the rays blackish; the tail fin is olive tinged with orange on its lower edge, and profusely spotted with black. I have been particular in describing in detail the coloration of this fish, which is the form that lives in the more quiet waters above the last falls of Whitney's Creek before it flows into Kern River, because I have taken at the mouth of the creek a golden trout and a Kern River form, another about six hundred yards above the mouth and below the lower falls, and about a dozen or more above the falls. In these localities, the extremes of which were hardly a mile apart, three fish of different coloration and form were taken, yet they were all rainbows. The Kern River fish weighed three 
pounds, was bluish in color above the lateral line, and profusely black spotted, but with no golden hues, and with distinct slashes of reddish orange along the throat, and a well-defined pinkish lateral band, a typical rainbow. Going up the creek, which came roaring down the gorge, with the same tackle and lures, a trout weighing half a pound, orange-hued, but without the bright golden coloration of one which I caught an hour afterward above the falls, distant only about five hundred yards farther up the stream. I could not understand at the time this singular confusion of form and coloration caught in the same water, and so near each other, except by concluding the first fish, taken in the lower part of the creek near its mouth, was a pure Kern River form; the second a fish of the same species visiting or living in Whitney's Creek, the waters of which were of a milky color having chemical constituents that effected, slowly or instantaneously, the sensitive color pigments under the skin of the fish. The typical golden trout taken above the falls was a perfect specimen, similar in coloration and characteristic markings, as above described. Thus my experience on this outing leads me to believe in the dicta of American ichthyologists that the 
golden trout of Mt. Whitney are descended from the Kern River trout; but how the progeny ever managed to mount or leap the lower falls, at least forty feet in height and perpendicular, is a mystery yet to be unveiled.

This trout, with its gleam of gold, is a very active fish, necessarily so below the lower falls, where the stream is rushing over its rocky bed at the rate of thirty miles an hour, with only, here and there, a small pool averaging about two feet in depth, hedged in by large and jagged masses of rock; and in these shallow holes, for they can be called only by that name, this fish lies and rises eagerly to the feathers dressed on the usual standard patterns of the ordinary trout flies in use all over the country.

The proper season to visit the Mt. Whitney waters is from July to September; they are most easily reached by rail, and within fifty miles of the fishing grounds, the shortest route being via Reno, to Mound House, thence to Pine station, where guides and outfits can be had to ascend by trail the Cottonwood Cañon to the high Sierras and to Mt. Whitney.

The habitat of the golden trout, according to Dr. Gilbert, is confined to the mountain streams 
on the west side of Mt. Whitney that are tributary to Kern River, and to its south fork; it has been largely introduced into streams about Owen Lake on the east side of the mountains, waters that were formerly entirely destitute of trout.

Of the three foreign species of salmon-trouts transplanted to American waters, the best known by anglers is the German or brown trout (Salmo fario), which were planted in our streams in 1883 . This fish, in its native waters, particularly those of Great Britain, presents all the varied characteristics of coloration and form that distinguish our American trouts. In England, there appears to be, at least, twenty trout living in streams not distant more than twenty-five miles from each other, which the resident fishermen designate by names such as "Tweed trout," "Teviot trout," "Ettrick trout," etc., the source of the nomenclature being the name of the river in which the fish lives. These trout are all fario, but are readily distinguished one from the other by the shape and bulk of the body and its distinctive coloration.

The brown trout was the fish caught and eaten by the ancient monks, and so ideally treated upon by Walton and Cotton, by the Prioress of St. 
Albans in her quaint old English, and poetically by Ausonius in the sixth century. It is the oldest and best-known salmon-trout of the Eastern Hemisphere, for there is hardly a county in England without its trout stream, and it is well distributed over Scotland and Ireland and the waters of the Continent.

The brown trout has lost popularity among numbers of American fishing clubs and anglers because of its rapid growth, large size, and consequent ability and inclination to devastate waters in which our smaller trouts live. Being able to exist and thrive in waters of a higher temperature than is adapted to other trouts, they should never be placed in streams which the latter inhabit. True, most, if not all, of our native salmonoids are cannibals, in fresh or salt water; but owing to the size of the brown trouts and the practice of putting them in comparatively small and shallow trout streams, where they can ravage at will on fontinalis, planting of them should be discountenanced and discontinued. One club, the Castalia of Ohio, owning the grandest trout stream in America, finding that the introduced brown trout was destroying the Eastern red-spotted charr (fontinalis), used, and may still be using, 


\section{Brown Trout}

every means to destroy them; and similar action will be and should be taken by every lessor or owner of water inhabited by our native trouts, if the foreign fish has unfortunately been introduced therein.

When the angler is fishing a trout stream, particularly one east of the Appalachian Range, he will be apt to hook a brown trout, and may be at a loss, upon seeing the red spots on its body, to distinguish it from the native red-spotted trout. This is not difficult. The scales on the indigenous Eastern fish are nearly microscopical in size, on the brown trout they are larger and easily seen by the naked eyes; the imported fish is without the mottlings or wormlike markings (vermiculations) on the back, which are always prominent in fontinalis; and on the latter, the red spots are present above and below the lateral line, while on the former, they are larger, seldom found below the median line, and there is a row of them almost invariably along the middle of the body. Again, the brown trout is a salmon trout and fontinalis a charr: put your finger in the mouth of the former and you will find on the roof a double row of teeth running down the central bone or vomer; in the mouth of the 
charr you will find no teeth on the front part of the vomer.

In the waters of the Eastern states the brown trout grow very rapidly, averaging nearly a pound increase in weight in a year, while in England they are much slower in growth, hardly onethird of a pound in the same period. In foreign waters, particularly in Ireland, they reach a weight of thirty pounds; the largest growth in American waters so far as I know is eleven pounds, and that specimen was doubtless one of the original stock hatched out in $188_{3}$, from eggs sent from Germany in the late fall of 1882 . They are reported as growing faster and to a greater size and better condition of flesh when foraging for and getting regular meals of insects. This may account for the rapidity of growth in American streams, where insect life swarms below and above and around the waters of the pools.

The brown trout is in its prime for the rod from about the first of May to the middle of September, during which period it rises freely to the artificial fly; and in our Eastern streams it appears to be indifferent as to the color and form of the feathers, rising to any dressing; better, however, in the gloaming than in the brighter hours of the 
day, a habit equally prevalent among other trouts and strikingly shown by the small-mouthed black bass. In English waters the practice of the brown trout of rising viciously to the surface at any moving thing is acutely developed; it is said to rise at swallows skimming over the surface, and that on one occasion a tame gull had its leg broken by a fiercely rising fario. J. J. Armstead, an English fish culturist, relates a singular incident in which it appears that "The biter was bit." He says that he was standing by one of his ponds when a large bee came along and took a "beeline" right into the water. Undismayed, the insect went spinning along the surface. Suddenly there was a splash and the bee went down, but in a few seconds rose to the surface somewhat out of gear. In two hours afterward a trout floated dead on the top of the water-a priori, the bee stung the fish unto death; a posteriori, the fish killed was another fellow that died from natural or other causes, and when dead arose to the surface.

In Great Britain the pursuit of the brown trout is earnest and reduced to a science. Innumerable dressings of flies are in use, some with cork bodies and fish-scale wings, and many without 


\section{6 \\ The Trouts of America}

these constituents are rubbed with vaseline and other oily substances that the line may float naturally in up-stream fishing, when the angler is dryfly fishing. The majority of American anglers are content to dry their flies by switching them. six or more times in the air previous to dropping them into the water. Gossamer leaders and midget flies tied on hooks as small as Nos. 18 and 20 are in general use in Great Britain, and the accepted method is fishing up-stream when the fly floats as a dead one, and the casts necessarily frequent, or the flies will float too near the angler to be retrieved properly for the next cast. Dry-fly fishing is not adapted to the swift-running American streams, but I have often practised it when wading down by leaving the water and fishing the pool below from its foot. They frequently spin the minnow for trout in England, and when a deep troll is necessary the lead or sinker is placed inside the minnow, a practice which has never been followed with us, although a good one for lake trout and other large fish of different species.

The angling authorities of England recommend thirty-two flies as the most attractive to the brown trout, consisting mainly of the palm- 


\section{Brown Trout}

ers, the duns, the spinners, the February Red, the March Brown, the Alder, the Stone, the Sand-fly; these are said to kill always when the fish are rising. It must not be forgotten that the flies recommended in Colton's addenda to Walton's "Compleat Angler," published in 1653, are even now among the most deadly for trout, not only in England, but in America.

The brown trout is, in American waters, rather slimmer in build than our American red-spotted trout, with a larger and more pointed head. The back is dark green covered with well-defined black spots, and the dorsal fin has both black and bright red or vermilion spots; the adipose, or fatty fin, is also beautifully decorated with three red spots. Below the lateral line the coloration is of a yellowish cast with a greenish silvery background. The tail, or caudal fin, is square, and on its edges there is a reddish stripe; the other fins are orange in color, the ventral and anal having a white stripe on the under edge shaded with deep orange; the head, the under part of which is yellow, and the gill covers are covered with dark spots, the belly is pure white, above which is a deep yellow hue. The fish commence spawning in New 
York waters in November, and have been found to continue to do so until February, the ova hatching out in about sixty-five days at an average temperature of forty-five degrees.

In Great Britain many experiments have been made in crossing the brown trout with other species, one of the most interesting being the cross between fario with our native charr (fontinalis). The progeny are marked like a zebra, hence their name, "zebra trout," of which it is said that at one time they lived in a stream at Ringwood, New Jersey, on the estate of Hon. Abram S. Hewitt, where they were the result of a cross between our brook trout and the brown trout as in England. These zebra trout are barren and greatly subject to deformation; they rise viciously to the fly, leaping into the air for it; they also leap on a slack line when hooked, the latter trait being one I have never seen shown by our much loved red-spotted charr. Crossing the salmon-trouts with the charr-trouts results in mule fish, not breeders; but the interbreeding of the charrs with other of the same genus brings forth fertile progeny, and crossing the salmon-trouts with salmon-trouts has a similar result. 
Over the Lake Leven trout (Salmo levenensis), there has been much discussion by English anglers and ichthyologists, as to its being a separate species from the brown trout, or a landlocked sea-trout (Salmo trutta). No decision has been reached and doubtless never will be; fish inhabit an element in which we cannot exist, hence our knowledge of their traits is mainly derived by stream observation from the banks of the waters, and in the tanks or pens of the fish culturists; a wild fish, however, roaming and foraging in its native waters, is apt to possess habits widely diverse from those of its imprisoned congener.

Loch Leven trout were introduced from Scotland in 1885 , and have been widely distributed in the United States, and are now propagated by many state fish commissions with success, the foreign fish spawning about the same time as the red-spotted trout. It is about equal in fighting qualities to our Eastern species, rising well to the artificial fly, with a peculiar qualification of this habit in its native habitat, where it seems that two trout of distinct colorations exist, one silver and the other yellow. These fish are said to rise to the fly on alternate days, 
neither encroaching upon the hours in which his brother, or sister, is feeding. The Loch Leven trout grows to the size of four pounds, but the average is about a pound or slightly over. They take the fly best and give great play at three years of age.

The native habitat of this species of foreign salmon-trouts is in Scotland, and the fish takes its name from the now ruined castle in which Mary Queen of Scots was confined by Queen Elizabeth, and from the waters of the adjacent lake-Loch Leven. This trout was brought to America about fifteen years ago, and has been planted in many waters in the Eastern and Western states with a measure of success. It is a beautiful and gracefully formed fish, and although closely allied to the brown trout, it may be readily distinguished from it by the absence of red spots, which are always distinctly seen on the body of the brown trout. However, it is reported that faint reddish spots appear on the sides and back of the Lock Leven form when the fish reaches an age of about four years. This absence of red spots when the Scottish fish is less than four years old seems to be a matter of fact with British anglers; but as the Loch Leven trout seldom 



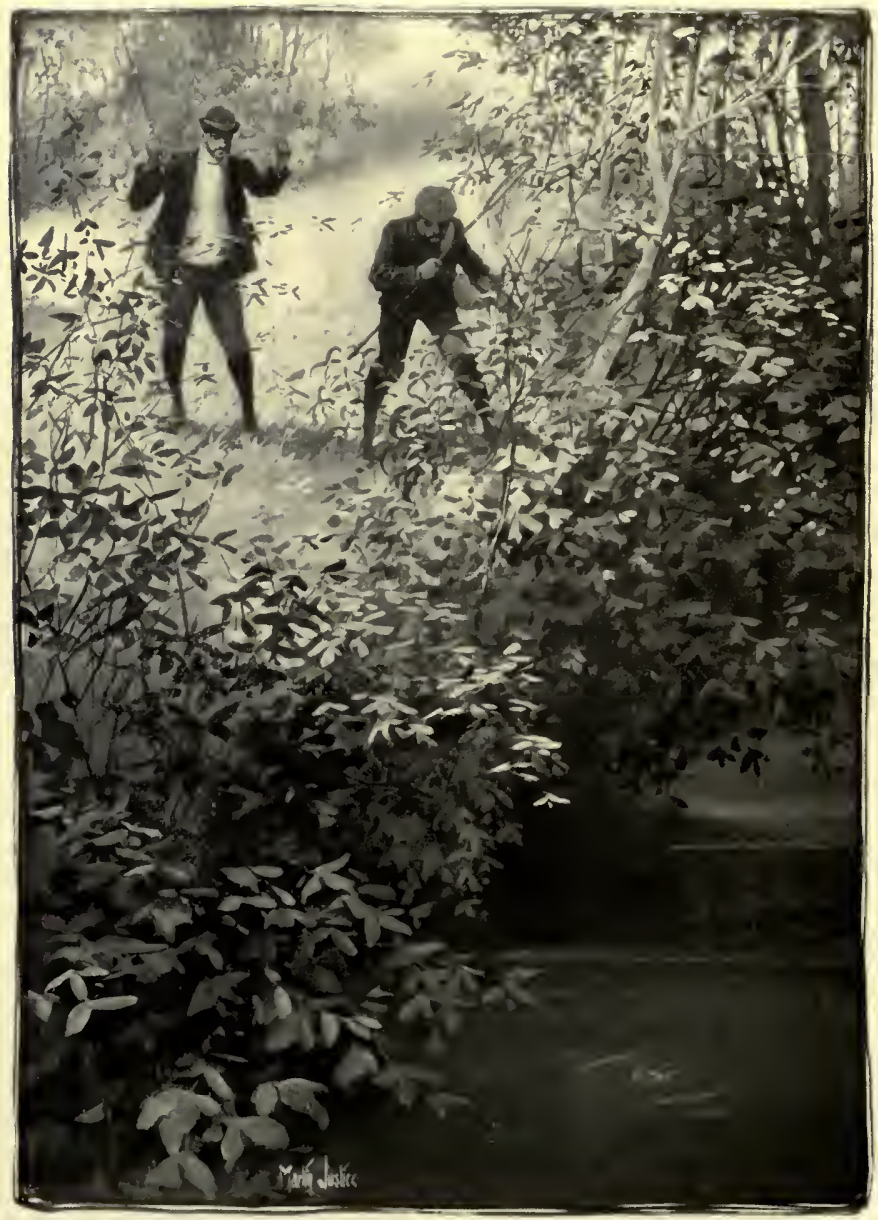

WHERE THE BIG ONES LIE 
grows beyond three pounds and consumes four years in getting to be about two pounds in weight, but little confusion, in recognizing either species, will occur over this red-spot theory, or fact, as the case may be.

Another foreign salmon-trout, "the sea-trout of Europe" (Salmo trutta, the specific name being the derivative from which the word "trout" arises), has been sparingly introduced and reared in American waters. It must not be confused with the native sea-trout, which is a charr, the difference between the two fishes being plainly indicated by the location of the teeth on the roof of the mouth, as has been explained in a previous chapter. Various popular names have been given to this fish, such as "guiniad," "bull-trout," and "salmon-trout." Its habits are similar to those of our indigenous sea-trouts; it is migratory, and is found running up streams emptying into the Baltic and North seas, and in those of Great Britain, being very numerous in Scottish waters; it also runs up the Seine and Loire in France, where it is called truite de mer, and is not infrequently taken on the southern shores of the Crimea. It hybridizes with other salmonoids, and that fact is one of the primary causes of the great 
282

The Trouts of America

diversity of European forms and colorations in the salmonidæ family. To this fish properly belongs the name of salmon-trout. It is a game fighter, yet is apt to take a troll of natural minnow or an artificial phantom more readily than the feathers placed ever so gingerly by the flycaster. 


\section{CHAPTER VI}

THE CHARR-TROUTS, THEIR HABITS, EXTERNAL MARKINGS, AND CLASSIFICATION - THE GREAT LAKE TROUTS AND METHODS OF CAPTURE THE EASTERN BROOK TROUT, DEVELOPMENT AND EXTENT OF THEIR SENSE OF SIGHT, HEARING, TASTE, SMELL, AND TOUCH

THERE are two genera of the salmonoids, popularly called brook trouts, that are more highly organized than the salmon-trouts; they are known as charrs. They live and thrive in wild waters of a temperature not more than sixty-five degrees, and, in whatever stream they may be, they constantly seek the higher reaches to spawn. If the mouth of their home waters is not distant from, and is in junction with, a salt estuary with no physical impediment, so soon as the ice forms in the stream the brook trout goes down into deeper water, and subsequently migrates and adapts itself to living in the water of the sea. Below the southern line of the state of New York there appears to be, however, a barrier of warmer water into which the brook trout does not enter, in 
despite of the strong natural instinct of the fish to migrate to "bitter water," as the Germans call it. In New England, Canada, and also along the south shore of Long Island, one of these charrs (fontinalis) goes down to the estuaries and feeds, grows lusty, getting flesh of deeper salmon color and a more robust form, and remains in his new habitat until the instinct of spawning impels him to migrate in the following spring inward and upward. Other fresh-water fish find a congenial habitat in salt water. This habit is strikingly shown in the so-called pike of Chesapeake Bay, which is the Eastern pond pickerel (Lucius reticulatus) of the fresh waters east of the Alleghanies. In some of the bays and estuaries of the New Jersey coast this pickerel exhibits the same inclination for a salt-water life. The black basses also find the brackish waters congenial; and this peculiarity is not confined to the largemouthed black bass of Florida, in the waters of which state many of the fishes of the rivers and numbers of those which habitually live in salt water, interchange temporary habitats.

The most prominent external marking by which the salmon-trouts and charrs may be distinguished apart, is the presence of red or crim- 
son spots on the body, the only exceptions being the Great Lake trout with grayish markings, and the Arctic trout (Salvelinus arcturus), upon which no reddish spots have been found; further investigation will, doubtless, show that this peculiarity of the latter charr does not exist, for reversals of stated facts have occurred frequently in ichthyic annals, and such is more likely in this case, as the Arctic trout has the most northern habitat of any of the salmonoids, and only a few specimens have been examined by specialists. I have on a previous page differentiated the charr from the brown trout, the only salmon-trout having persistent red spots in our waters. The location of the teeth has been previously described as serving for a mark of identification; those on the hyoid bone (base of the tongue) are said to be always present in specimens inhabiting streams south of New York, while they are only occasionally found on trout living farther to the north.

There are thirteen species and subspecies of native charrs in American waters and two imported species from Europe. They are classified as follows :

The Great Lake trout, - Cristivomer namaycush (Walbaum). The Siscowet, - Cristivomer namaycush siscowet (Agassiz). 
The Brook or red-spotted trout, -

The Dublin Pond trout, -

Salvelinus fontinalis (Michill).

Salvelinus fontinalis agassizii (Garman). The Dolly Varden trout; Oregon charr; bull trout; malma; golet, - Salvelinus parkei.

The European charr; saibling; ombre chevalier; Greenland charr, - Salvelinus alpinus.

The Long-finned charr, -

Salvelinus alpinus alipes (Richardson).

The Greenland charr, -

Salvelinus alpinus stagnalis (Fabricius). The Arctic charr, - Salvelinus alpinus arcturus (Günther). The Sunapee trout, - Salvelinus alpinus aureolus (Bean).

The Oquassa trout or blueback, -

Salvelinus oquassa (Girard).

The Naresi trout, - Salvelinus oquassa naresi (Günther).

The Lac de Marbre trout, -

Salvelinus oquassa marstoni (Garman).

The imported species are :-

The Swiss Lake trout of Lake Geneva, - Salvelinus lemanus. The European charr or saibling, -

Salvelinus alpinus (Linnæus).

The first of this series of fifteen charr trouts is the Great Lake trout (Cristivomer namaycush - the generic name is from the Latin, crista, "crest," vomer, "vomer," in allusion to the structure of the bone on the roof of the mouth; the specific title is an Indian name). This charr is 
rich in baptismal nomenclature; it is, in addition to the name of Great Lake trout, called Mackinaw trout in the region of the Great Lakes. In other sections of the Northwest it is known as the "namaycush"; it is the "siscowet" or "siskowitz" in some parts of Lake Superior, and in the northern part of New York it is sometimes called "lake salmon." At Green Bay, Wisconsin, those that have salmon-colored flesh and black bodies are called."black trout"; those with white flesh, "lake trout"; around and in Traverse Bay, Michigan, the variety taken in shallow water, being long and slender in form, is called "reef trout," and when larger it is known as "a racer," and specimens of another variety are called "potbellies." At Grand Haven, Michigan, they are known as shoal-water and deep-water trout, and "buckskins" is the name given them around Thunder Bay in Lake Huron. Coming east we find that "togue" is the general name in most sections of New England, except in Maine where "lunge" is the accepted appellative with a good many fishermen. In Canada we hear applied the name of "forked-tail trout"; "lunge" in New Brunswick, and "tulade" very generally in the Eastern Provinces; in other sections the 
names, "tyrant of the lake," "silver lunge," and "black salmon" prevail, and last, not least, the euphonious title of "masamacush" represents the Indian idea of the proper name for the Great Lake trout.

As a compensation for this mass of popular and confusing names, this fish is without doubt the most easy of recognition, for it stands alone as a charr in its characteristic structure, of which the bone on the roof of the mouth is the most striking; it is a raised crest armed with teeth, lying behind the vomer and free from its shaft, and a finger placed in the mouth of the fish will at once reveal this crest, also the presence on the base of the tongue of a strong band of teeth, coarse and sharp like a wool card.

The head of the lake trout is very long, the upper part somewhat flattened, the mouth is large; tail well forked and the adipose or fatty fin is comparatively small. The coloration varies greatly; sometimes it is a dark gray, then pale, and occasionally specimens are taken that are nearly black; this coloration is frequently seen when lake trout are confined in the pens of fish culturists. Over the entire body will be found pale spots, which are sometimes tinged 
with red, and on the head are usually seen wormlike markings somewhat similar to the mottlings on the back of fontinalis. It is a large fish, growing to a reputed weight of one hundred pounds; but the average of those caught by hookand-line fishermen during a long summer's outing will average hardly six pounds.

The lake trout comes to the surface very early in the spring, and in states where the law permits, the angler trolls for them on or near the top of the water, the fish making a "boil" and taking the lure viciously, but rarely jumping into the air, unlike the brook trout, which, when deceived in its judgment as to the position of the bait, and missing it, will often make a graceful archlike curve as it reënters its element. The proper tackle for surface trolling consists of a very light sinker, a twelve-thread cotton line, a No. 5 spoon, from which is taken all the gang hooks, and a single No. 8 substituted, the latter to be attached to the lower end of the spoon by a snood six to eight inches long (the use of treble gang hooks is to be abominated at all times and for any fish); a good multiplying reel and an eight-ounce rod, not longer than nine feet; the bait a golden shiner or any other of the 
cyprinoids (carplike), and a large one of six or eight or even ten inches, if the lake trout run big, is most seducing to them. Many anglers do not use the spoon, relying entirely upon the attractiveness of the natural bait; but my experience has convinced me that the revolving wings or flanges of a bright spinner draws the attention of fish to the bait from a long distance, and that, when reaching it, they take the minnow voraciously, seldom striking at the spoon.

The question as to the lake trout taking an artificial fly when cast on the surface has been a vexed subject of discussion among anglers. In my judgment and experience it is merely one of where we find the lake trout. If at the mouths of large rivers, such as the Nepigon, or in comparatively shallow waters over ledges of rocks in the lakes, during the early spring months, or in the case of the river just named or similar ones, some miles upward from their mouths, the lake trout will surely take an artificial fly. This has been verified by anglers of high standing and of undoubted good faith, who used flies dressed on No. 8 hooks and of the patterns known as Seth Green, Bishop, and Silver Doctor. 
The deep-water troll requires more elaborate tackle than that used in surface fishing. Attach a cone-shaped sinker to the end of the reel line of not less than three and from that weight up to sixteen ounces, the size being dependent on the character of the bottom of the water you are fishing and the style of fishing you prefer - a long or a short line; if the bottom is full of rocks, jagged in shape or crowded in position, your line should be strong and your sinker comparatively small; the same holds good if on smooth bottoms when you fish "slow and far off "; if you have a penchant for fishing with a short line, your sinker must necessarily be heavy. You will need no rod; the line held in the hand will enable you to be more sensitive to the slightest touch of the lead on the bottom, which you must feel as your boatman rows slowly and regularly along. If, however, you wish to use a rod, lay it down within convenient reaching distance, holding the line in your hand, and when you feel the pluck of a fish and fasten it well, take up the rod, being careful to keep the proper strain on the fish when lifting the rod. Three feet above the sinker attach a single or double twisted leader (average weight 
of fish that are feeding should determine its character) and two other leaders placed above the first, from six to ten feet apart, the distance to be judged by the depth at which the lake trout are taking the bait. A gang of three hooks is usually placed at the end of each leader, but a lip hook and another larger one are to be commended as more sportsmanlike. Place swivels wherever needed, and let your sinker line be three feet long and weaker than the reel line, so in case of getting hooked among the bottom rocks or a snag you will only lose the sinker. Bait with a large minnow as suggested in surface trolling, and above all things charge your boatman to row slowly and with a cadenced movement.

"Baiting a buoy" is a favorite method with some fishermen, and it is very similar to the English practice of "ground baiting." Anchor a buoy strongly in deep water, and when it is in position throw over and around it cut pieces of meat or fish of any kind; in one instance in the Fulton Chain, New York, a hind quarter of venison was successfully used. Bait the buoy for two or three days, then let a day or two intervene, and fish on the following one. An ingen- 
ious angler when fishing at a buoy, after his boat is fast to it, throws over at regular intervals of a few minutes a handful of white beans which, as they sink, appear to attract the fish. Use a heavy sinker, bait with a dead minnow and keep it in motion by jerking or jigging it up and down for a foot or eighteen inches from the bottom.

There is another form of the lake trout popularly known as the "siscowet" or "siskowitz" (Cristivomer namaycush siscowet), which is said to be only found in Lake Superior. It has a shorter head, but the same general coloration as its cousin the lake trout, and there are no material structural differences between the two fish other than the shortness and breadth of the head and the unusual fatness of the flesh of the siscowet; the deeper the water in which the fish is found the greater the richness of the flesh. The market fishermen of Lake Superior recognize two species or forms of the siscowet, one living in water six hundred to a thousand feet in depth, of which Mr. R. O. Sweeny states that at this enormous depth the pressure on the wooden pieces of the nets used in catching the siscowet causes these symmetrical blocks of 
wood, sunk only a few hours before, to become so crushed and broken as to be useless thereafter. The fish at this great depth feed on myriads of worms that swarm on the blue clay bottoms of certain parts of the lake, and get so fat that when brought to the surface and relieved from the great pressure, seem ready to burst; in fact, some of the fat vesicles become ruptured, as indicated by the floating oil on the water at and around the spot from which the fish have been taken. This fish is caught by the rod-and-line fishermen, by still fishing, and occasionally at baited buoys.

We now reach the charrs proper and undefiled in their beauty of form, velvety richness of coloration, the chosen of anglers and the gourmet.

As will be seen from the schedule previously given, the American charrs consist of two genera, five species, and eight subspecies or varietal forms. Of the first genus (Cristivomer), there are one species and one subspecies, which are popularly known as the Great Lake trout. The other genus (Salvelinus) includes all the charr trouts except the two named above. This genus is subdivided into four species, and again differentiated into seven subspecific forms: that 
of fontinalis into one subspecies, the Dublin Pond trout from its resemblance in structure and markings to the Eastern brook or "speckled trout"; that of alpinus into four forms, from their anatomical similarity to the saibling or the charr of northeastern America and of Europe. These four subspecies may be distinguished from fontinalis on sight by the absence of the dark mottlings or wormlike markings on the back, which are always present on the "speckled trout." These saiblings are popularly known as the long-fined charr, the Greenland charr, the Arctic or Floeberg charr (all of Arctic habitat), and the Sunapee trout. The fourth species (Oquassa) has two subspecific forms, so classified because they are anatomical analogues of the typical Oquassa or blueback trout of Maine; they are popularly known as the Naresi trout (Arctic America) and the Lac de Marbre trout of Canadian lakes. The Dolly Varden trout (Salvelinus parkei), a native of Western waters, but recently introduced to Eastern habitats, is a species unto itself and has no close relatives as yet discovered, if we except the malma trout of Kamchatka, which, in fact, is the type of the species; it is techni- 


\section{6 \\ The Trouts of America}

cally known as Salvelinus malma, and has not been found in any other waters than those of Kamchatka.

The spawning habit of trout (fontinalis) are similar to those of other members of the salmon family. At the approach of winter they go up to the head waters, or as near them as the conditions permit; in fact, from the time they leave the deeper lower waters, to which they resort after spawning, they head up-stream constantly, taking advantage of every rise in the brook. The reproductive instinct impels them to do this, and as the warmer months come this feeling grows stronger and stronger, and although they seek in hot weather the health-giving spring hole and the cool depth of a pool and remain there for some time, they are apt, as soon as a greater volume of water pours over the shallow rapids, to look for other comfortable quarters, but always higher up. It is the practice of experienced and observing fly fishermen who have from day to day noted the haunt of a large trout, and missed his presence there, to seek for him in the next likely pool up-stream.

Arrived at the spawning ground in October or later on, the female shapes with industrious care 
a little nest in the gravel, fanning it clean with her tail and removing the larger pebbles in her mouth; the male, all the while, moving slowly and gracefully above, below, and around his mate, as if to let her see and admire the gorgeous bridal robe of olive velvet and gold with which nature has adorned him. After displaying for a few moments with a natural vanity the beauty of his nuptial array, approaches her, rubs his body against her side; and soon after she enters the nest, emits a few eggs, which the male fertilizes by ejecting milt upon them. This process continues until the reproductive act is ended. Scarcely five per cent of the ova of the female is productive, owing to several causes, the main one being the destruction of the eggs by the hordes of minnows and other spawn-eating water animals; the trout, both male and female, leaving the ova unprotected immediately after spawning.

The type of the thirteen varietal forms of the charrs is the brook beauty of the Atlantic slope - Salvelinus fontinalis, "living in springs." It is the fish beloved by American anglers, an ichthyic confuser of the savants of the last decade in their desire to reduce the charrs of our waters into one polymorphic species, which 


\section{The Trouts of America}

has resulted in multiplying them; the objective quarry for the skilled and the tyro in their mountain outings; and the favorite fish of the old masters of the art in America, Thad Norris, Seth Green, Prime, Inskeep, and others. We do not and can not wonder at their choice when we take this charr in hand and glance at its symmetrical form - a cleaver of the water and the varied hues of its mellowed coloration, diffused in softness of tone over its entire body, with no jarring flash of color to mar its fulness of beauty.

In structure fontinalis is fitted for its wild life in the tumultuous mountain brooks, fitted to breast the rushing rapids, wherein it poises, self-contained in body, and apparently in spirit; motionless often in a ten-mile torrent, awaiting the drowned or struggling insect or more substantial food surface-washed by a rise of water. Impelled by the spawning instinct, it seeks the upper waters in the last days of summer and early fall; its vigor of muscle enables it to get to them, bruised and somewhat torn of fine symmetry though it be by its nuptial-seeking journey. It will leap over and sometimes swim up the centre of three feet of water of a dam over 
which a downpour twelve or more inches in volume is ceaselessly passing, and, in strong contrast with this muscular attainment, and apparently enjoying the relief from a morning's work, like a schoolboy in his noonday's recess, this trout can be seen in a quiet pool above the dam disporting and leaping leisurely and lazily from the water; and I have found them when at play - it can be called by no other name - to disdain all feathered or natural lures; they are having a holiday, and a full stomach would, as it were, handicap their acrobatic enjoyment. When the nuptial season is over, our mountain charr goes down-stream to deeper water, often fifty to one hundred miles below the spawning bed, to recuperate from the effects of reproduction, and early in the spring months can be taken miles below the confluents in which it reproduced its kind and lived the greater part of its life.

No other fish known to anglers possess habits so free from grossness as the brook trout of the East. His primary need is oxygen, and he seeks it where it is found in greatest quantities - the upper reaches of strongly aërated mountain streams. There you will find him in the full 
fruition of game qualities. Cast a fly to him, and when hooked he seems to know, unlike his congener of larger waters, every rift, nook, rooted hole, and protruding or shelving boulder of his rock-ribbed environment; and this knowledge of his home waters is put to practical use, - roots, rocks, holes, and shallows are frantically sought as resources of protection or escape; and when you hold him, seemingly exhausted, hard and fast in your hand, to take the hook from the mouth, he will draw his muscles tense and strong in a final effort for liberty, - no other game fish, to my knowledge, make this powerful, convulsive struggle after capture and apparent exhaustion.

It is in a stream like the one described above that trout are compelled to forage vigorously and industriously for food, often on restricted pastures; and the wear and tear of vitality when living in precipitous waters is constantly at work on the muscles and the arterial system; neither can find rest where no deep pools abound to which the fish can retire for security, repose, and digestion; moreover, if a relatively deep shelter from the boiling waters exist here and there, it will doubtless be preëmpted by a 


\section{The Brook Trout}

larger fish of the same ilk, the autocrat of the pool, whose simple presence is a sign mark" No trespass here."

Gifted with æsthetic proclivities, and as, we have seen, at the same time exhibiting those of the athlete, the trout has been accused of being a coarse, if not a gross, feeder, because he has been known to eat small water snakes. True, he is somewhat of a glutton, for I have seen a trout on more than one occasion take a fly with the tail of a minnow protruding from his mouth. We also know that, with the stomach apparently filled to repletion, they will rise lazily to a fly and flop it with the tail to drown or disable it and then leave it floating down-stream. But this only shows that the choicest of the trout's menu is irresistible to our water sprite, and he may be in this respect likened unto the gourmet, who dallies with dainty bits when he is gorged with the daintiest of them. Moreover, our stream beauty will not touch carrion of any description; his food must be of the air born, or of the stream fresh and pure, and as to his eating snakes, snakes eat trout, big and little, if they can capture and swallow them, but it is to be doubted very much if our charr could be 
tempted to eat a crumb of garlic, or even a piece of carp when dressed, condimented, and cooked in the German style. He is like all land animals, including the genus homo; when hungry he will eat whatever he can get if the food be not repulsive from over ripeness, and it must not be forgotten that this quality is sought for by many epicures among us, who are blasé in all things, including appetite.

The technical description of this charr by ichthyologists agrees substantially with the observations of anglers of stream experience. The body is long, little compressed, only slightly elevated, its curved lines symmetrical and tapering posteriorly to its large, nearly square, and powerful tail fin. The eye is also large, albeit the fish is said to be near-sighted; the head is big but not long, and the snout somewhat blunt, the space between the eyes being rather broad. The marring feature of this clipper-built fish is the large mouth, almost cavernous; looking at it in profile, it will be found that the upper jaw reaches backward beyond the eye. This condition is characteristic of fontinalis, and with the dark vermiculations on the back will serve to distinguish it at once from the other charrs. The col- 
oration is striking; the red spots, sometimes ocellated with blue, are brighter or fainter under the influence of a dark or light, temporary or permanent, habitat; they are seldom seen on the back, but those on the sides are always present and irregularly placed, and unlike those on the German or brown trout they are seldom, if ever, located in a regular row just above or slightly below or directly along the lateral line. The belly is usually a creamy white, and all of the body in the male fish during the spawning season becomes clothed in a rich orange-gold, a fit bridal robe for this pride of the rills. The texture and appearance of the skin is somewhat velvety, and the mottled fins on the back, with the distinctive light bands on the belly fins, in contrast with the orange-golden hue of the sides, justifies the angling phrase so often heard on the stream - " the glow of the trout."

The coloration of this charr presents curious contrasts. Some become dark and dingy as they grow old and blind; others again have been found without red spots when living side by side with their congeners of brilliant ones; and others are born albinos. The cause of a uniform black or blackish coloration in fishes living in surface 
streams is due to the action of the nerve of the eye on the color glands, for when the fish become blind they always assume a dark coloration; when the nerve of the eye ceases to act, the color glands lose their motive powers. Through our eyes we receive perceptions of color, shades, or tints, which are transmitted to the brain; in fishes through the same medium, the nerve of the eye, these impressions act upon the color glands, and are of course involuntary and entirely beyond the control of the fish. Upon dark-colored fishes living in cave-streams or underground lakes, a similar cause and a like effect constantly exists; the fish cannot see, for they live in perpetual night. Why trout are found in their native waters on which the glare of the sun or the subdued light of the forest gloom are constant conditions, the fish being without the characteristic red spots, and now and then assuming the abnormal coloration of the albino, is a difficult matter to explain; it doubtless arises from the defective action of the nerve of the eye upon the color glands, or petals, which lie under the scales and which open and shut when under the influence of color tints conveyed to them through the delicate nerve of the eye; certain nerve fibres in 
such cases producing the red spots on the trout and the diseased condition of others resulting in albinos. We find partial parallels in the man who is color blind, or the occasional human albino, and in the negro whose skin is gradually turning white, instances of which are heralded in medical journals. I have dwelt somewhat at length upon this subject of change of coloration, as many otherwise intelligent anglers persist in believing that this change of color is voluntary and subject at all times to the whim or will of the fish. They are in error.

In this connection it seems apropos to allude to the preservation of the color of a live trout after capture, that it might be mounted as a souvenir of a delightful or memorable outing. The receipts I give for what they are worth, as my experience in this matter is entirely confined to dressing the fish carefully, wiping it dry, and coating the body with glycerine, which preserves the life color to a slight extent. Our foreign brethren of the rod have given this subject considerable thought and practice; one of them, living in Germany, advises that the fish be handled as little as possible after capture, to kill it before extracting the hook by tapping it sharply 
on the back of the head with a round, heavy stick, then wrap the trout at once in a sheet of waterproof paper and pack it tightly, the back fin up, in fresh grass. Another, of England, believes in covering the fish with tissue paper immediately after capture, then rolling it in a damp cloth and packing it in a box or basket with soft packing. A St. Louis, Missouri, angler wrote to me: "To restore the brilliant coloring of trout after they have been on ice for a number of days, you must place them in strong brine with plenty of cracked ice in it. Let them remain in this bath five to ten minutes, and then wash carefully in the brine until all the adhering slime is removed. After drying they will be fully as brilliant as when first caught."

To fish a trout stream with success the angler should not only possess a knowledge of the habits, but also an intelligent idea of the scope and acuteness of the senses and intelligence, of the quarry he is seeking. Unfortunately, in our efforts to acquire this knowledge we can only depend upon unsatisfactory observations, and to some extent on analogy, using our own senses as a basis.

Some authorities state that a trout is a very 


\section{Sigbt}

near-sighted fish, and limit their range of vision to eight or ten yards. If this be so, and it is a very close estimate, open to dispute, the trout has much weaker eyes than the black bass, which I have seen come to my flies from a distance of at least forty-five feet, making a plainly discernible wake across a shallow reach of the river. The eye of the trout is, doubtless, well adapted to the element in which it lives. It has no eyelids, but, in lieu of them, the skin of the head passes over the eye and becomes transparent. The cornea, the admitter of light, is flat, not convex as in the higher animals, - a wise provision of nature for the protection of the eye in the battle for life waged at all times among fishes. The reflective apparatus of the eyeball of a fish, as in land animals, is the lens, which is of considerable density and size. It is a powerful agent in reflecting the rays of light, and were it not for the density of the medium in which it lives, the trout would doubtless be gifted with acute vision at long range; but the power of the eye in fishes can only be imperfectly estimated by observation of their actions from the banks of a stream or other places; it can only be conjectured as to what effect the water, as a medium, has upon the organ 
of sight in a fish. The shadow, as we see it on the surface of the water, of a passing bird, from which apparently the trout will shy and seek a shelter-hole, may not be the shadow, but the object itself which alarms the fish, for it is not an unusual experience on a trout stream to see fontinalis leap two feet at least into the air in its efforts to seize an insect fluttering over the pool. Looking from below or from above at an object through water as a medium, it seems to possess characteristics widely different from those it has when seen through the air; this was verified by an ardent angler of my acquaintance, who wanted to find out how an artificial fly appeared in its varied hues, to a fish looking at it from below. He filled the bath-tub with water and laid on his back at the bottom, having previously instructed a friend to cast a White Miller, a Black Hackle, and a Yellow Sally on the surface of the water. He came out of that tub no longer an earnest colorist of feathered lures, as he had formerly been; for he found that the three flies, of strongly contrasted coloration, appeared to his eye nearly all alike, differing only by hardly perceptible shades. To the eye of the fish things might have been reversed. 


\section{Sigbt}

No angler has ever caught on a mountain stream, or in any other water, a blind or partially blind trout, that was in good physical condition; it was starving because it could not see to feed. Observe a number of trout in a stream with their heads up current; how they dart here and there at every small object that floats by them, at a distance often of ten to twenty feet, and then nose it, and, if unfit for food, turn tail upon it; but if an insect, alive or drowned, comes down with the current, they will seize and swallow it with avidity. In this case there is a combination of the two senses sight and taste.

Again, and from the angling standpoint, why does the farmer's boy who bushwhacks the trout from behind the bushes, or the cautious angler, adopting somewhat similar methods, catch more fish than one who splashes down-stream, when every bottom pebble, sand bar, or rock is glinting with the reflected light of a bright noonday's sun? Remember, also, that when fishing up a small stream in a dashing rift, the tumult of which drowns all possible noise made by wading against the current, that trout will come down, scurrying past the fisher's feet, from the eddies on either 
side of the rift - localities where the heads of the fish may be up or down or across stream, - they evidently could not hear the tread of the feet, as no vibration took place, and the roar of the rushing rapid drowned the sound of the splashed water by the feet and legs; hence the conclusion that they must have caught a glimpse of the angler or seen the threatening movement of the rod in the forward cast.

The old fly fisherman, knowing the acuteness, if not the compass, of the sense of sight of the trout, when fishing down-stream, always leaves it as he approaches a likely-looking pool, and makes a detour around to reach the lower end, and then casts his feathers, first upon the comparatively still waters below, then upward and across until he has corduroyed the "swim" with his trailing and fluttering flies. The result, as a rule, is marked and encouraging.

I sometimes think that the trout and the black bass have an intuition of the presence of an angler on the banks of a pool. They may not be able to see him clearly, but his form on the bank, even when the sun is full in his face, makes an impression, it can hardly be called a shadow, on the water which informs the wary fins that an 
unusual condition exists above, more particularly if the rod is in action. This intuition in the fish is not more extraordinary than that inspiring some old anglers, especially those of salt water, "to strike" when there is no indication of "the pluck" of the fish at the bait. Something unaccountable, yet felt, is going on down in the depths, perhaps a slight touch of the reel line by a passing fish or the gentle mouthing of the lure, without strain or movement, by a surfeited fish - the rodster knows not what, but a turn of the wrist is made and the scaly one boated.

Although the organ of hearing in fishes is but imperfectly developed anatomically, its acuteness is much more marked than that of sight, but only through the water as a medium, and then only by concussion on the surface of it. Boisterous singing or loud talking, the volume of which is diffused in the air, does not alarm fishes; but the slightest disturbance, stamping of the feet or dropping an oar on the bottom of the boat, will agitate and drive them from their feeding-grounds. They do not seem to be affected by noises originating in the water, for you can knock two heavy stones against each other under the water, and the trout remain placid and continue their feeding; yet 
tread ever so lightly on the low bank of a pool, and the fish are affrighted.

Again, fish do not seem to hear any sound produced by concussion on the bottom of a pool, of which my personal experience gave an instance. In a shallow and small indentation of the Schuylkill River (Pennsylvania), where some years ago fly fishing for black bass was glorious, I had moored my boat to a stake, the upper end of which protruded about two feet from the water. Having occasion to visit the little craft, I noticed three or four eight to ten inch bass lying in repose some twenty feet away from the stake, and in somewhat deeper water. Experimentally, I struck, with a short, heavy stick that was at hand, the top of the stake very hard, at least a dozen times, and doubtless created a strong concussion between the bottom of the river and the stake. To my surprise the fish remained undisturbed. Going ashore quietly, I selected a flat stone, and threw it into the water, at least fifty feet from the spot where the bass were lying, and on returning stealthily to the boat, found they had disappeared. In the first instance no vibrations on the bottom and thence upward were caused by hammering the stake, and in the second, sufficient concussion 
arose from the surface contact of the stone with the water to alarm the fish. Since this experience, I have been very cautious in wading a trout stream, always sliding, as it were, instead of walking on the bottom of it; stepping and splashing the water, hither and yon, creates a concussion whenever you lift your feet above the surface for another step forward. From the above facts it is evident to me that the hearing of fishes is developed only by concussion, except, perhaps, when they are feeding on the surface of the water, or leaping from it.

The angler cannot resist the belief that the senses of smell and taste are well developed in trout. They eject the artificial fly, if the hook is not fast in the flesh at the instant they note its non-edible nature, or when they feel the gritty impact of the hook. They will not eat impure food, and they have the faculty of perceiving odors, and various scents attract or repel them. This has been verified from the earliest days of our art, when ancient rodsmen used diverse and curious pastes and oils, which were seductive to fish; in Walton's day and long after this practice was followed and the records tell us of its success. When I was a boy and the Schuylkill River was 
swarming with the small white-bellied channel catfish, than which no more delightful breakfast food ever came out of the water, the only bait used to catch them was made of Limburger cheese, mixed with a patch of cotton-batting to hold it firm on the hook. No other lure had the same attraction for them, because, no doubt, of the decided odor of the cheese.

The so-called fifth sense, that of touch, is as acute in trout as it is in many other fresh-water fish. Find one in the shadow of a bank or shelving rock, and touch him with a feather, and there is nothing to be seen but a thread of silver and gold as it flashes out of sight; on the other hand, and under somewhat similar conditions, if the trout is in deep repose (that is, asleep, for no other word expresses its depth, and fish, like all other animals, must have their periods of absolute rest), you will be able to pass your hand, if gently done without touching the body, from the tail forward until your fingers reach the shoulder of the fish, when a sudden grasp will cause its capture; this is called "tickling a trout," and the practice existed long before the advent of Walton. In one detail of the manner in which it is done, I have never had much confidence - the tickling 



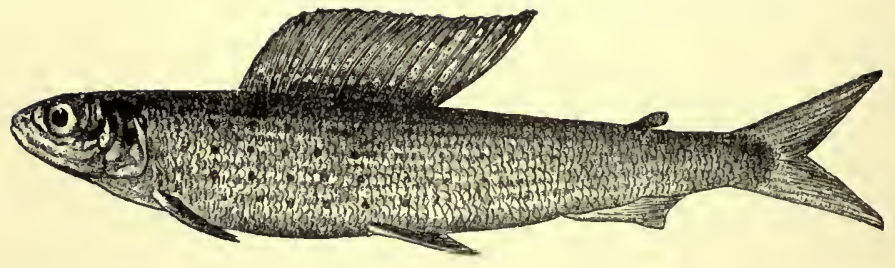

THE MICHIGAN GRAYLING

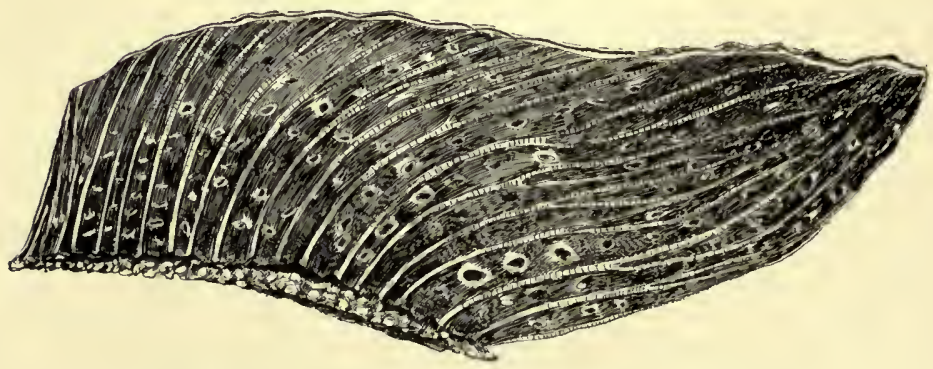

FIRST DORSAL FIN OF MICHIGAN GRAYLING

Reduced one-half. From a $1 \frac{3}{4} \mathrm{lb}$. fish. 


\section{Toucb}

part, wherein one of the fingers must scratch or tickle the belly of the fish, to make the hypnotism more complete.

In the foregoing notes I have taken our Eastern brook trout (fontinalis) as the object lesson, that fish being best known to me, but all that has been written will apply equally well to the other species of charr-trouts living in fluvial waters. The reader will, I hope, take what I have written as the expression only of opinion, based on personal experience and observation. I do not intend it to be in the least degree dogmatic. 


\section{CHAPTER VII}

THE CHARR-TROUTS CONTINUED; THE DUBLIN POND TROUT - THE DOLLY VARDEN TROUT - THE SEA TROUT, "SALTERS"-THE SAIBLINGS - THE ALPINE OR EUROPEAN CHARR OR SAIBLING - THE GREENLAND CHARR - THE LONG-FINNED CHARR - THE FLOEBERG CHARR - THE ARCTIC CHARR - THE SUNAPEE TROUT - THE OQUASSA TROUT-THE LAC DE MARBRE TROUT.

TAKING the other charrs seriatim, we first reach the Dublin Pond trout of New England waters (Salvelinus fontinalis agassizii), which is similar in structure to the brook trout (fontinalis), but differs from it in coloration, being pale grayish and almost without red spots, thus resembling the lake trout or togue. It is found mainly in Dublin and Centre ponds in New Hampshire, and Mr. A. H. Thayer, a resident angler, writes that the young fish are "as beautiful as a bar of mother-of-pearl." The adult fish living in deep water are much darker, with more brilliant red spots. These fish have somewhat peculiar traits as viewed from an angling standpoint; the young 


\section{Dolly Varden Trout}

will take the fly when in shallow water from about May 20 to June 10 , and then again in the spawning season from September I5 until November I. The early summer rise to the surface and their sudden disappearance on or about the tenth day of June is strikingly similar to the habit shown by the cisco or lake herring, which is also one of the salmonoids. The large Dublin Pond trout are seldom taken by any baits, no matter how deftly handled or alluring, only two or three having been boated any one season.

The Dolly Varden trout (Salvelinus parkei), with its coarser and more popular name of "bulltrout," is widely distributed in the western waters of the Rocky Mountain watershed; it is found as far north as Alaska, and south to the upper Sacramento River, thence eastward to Montana and Idaho waters. This trout has a stout body, which is deep and less compressed than that of the speckled trout of the East. It may also be known by the size of the adipose or fatty fin, which is unusually large, and the round red spots on the sides, those on the back being paler and smaller; this characteristic has not been observed in any other species of charr-trouts, the Dolly Varden, 
however, being the only one of them with a native habitat west of the Mississippi River. This peculiar marking will enable the Western angler to distinguish the Dolly Varden from our Eastern trout (fontinalis), which, perhaps, has been profusely planted in his stream, and do a like service to the Eastern angler, should he meet with the Western charr in the waters east of the Alleghanies, where it will probably be planted, if not already introduced in isolated cases.

The Dolly Varden is somewhat quaint and rich in its popular nomenclature. It was so called by the wife of a hotel keeper on the Sacramento River, who, seeing the bright coloration of the fish for the first time, exclaimed, "Why, it is a Dolly Varden!" in allusion to the variegated garb in which Charles Dickens clothed one of his heroines. It also has the names of Oregon charr, bull-trout, red-spotted trout, malma, and golet. The general color of this trout is olivaceous, and the fins are dusky with the whitish strip in front, as appears on those of the Eastern charr; but the Dolly Varden is without the wormlike markings on the back, like those on fontinalis. Sea-run specimens, growing to twelve or more pounds, are silvery with the red spots either faint 
or lost entirely. I have seen in a small brook flowing down from the Sawtooth Mountains of southern Idaho, at least two thousand miles from the sea, as the rivers run, a Dolly Varden weighing not less than six or seven pounds, which in the shallow water showed plainly all its distinctive and resplendent coloration. This trout was probably a sea-run specimen, which, like fontinalis, on its return from salt water had dropped its robe of silver for one of more brilliant colors, which it had worn when in its adolescence and living in a spring-water habitat.

None of the salmon-trouts or charrs rises more freely to the artificial fly than the Dolly Varden; when of a pound or so in weight, they have been taken with trout flies tied on No. 8 Sproat hooks, and the Dun fly and March Brown are generally alluring; these fish, however, are not fastidious in their feeding habits. In Alaska they swarm around the mouths of rivers, and a short distance up-stream is the best locality for fly fishing, although they have been taken with flies in salt water along the comparatively shallow but somewhat abrupt shores. The average of the fish so taken seldom exceeds a pound, and I have yet to learn, and possibly will, of a sea-run speci- 
men of ten pounds having been taken with a feathered lure, unless its attractiveness was reënforced by a bright, spinning spoon.

The Eastern charr that goes to the sea is fontinalis, the Western one is the Dolly Varden. The effect of their sojourn in salt water is shown in their rapid growth, a more rounded, thicker body, and the striking change in coloration. When they return from their ocean migrations, they have lost all their characteristic colors that adorn them in a fresh-water habitat, and become silvery in coloration, but assume, when belated, as has been stated, in returning to salt water, their original markings and colors. There is no anatomical difference in the structure of the Eastern sea-trout from that seen in the Eastern speckled trout, hence the former has no specific classification other than Salvelinus fontinalis; although deprived, as it has been, of this distinction, it displays to the angler qualities on the rod that entitle it to a high grade among game fishes. It is a persistent and eager riser to the artificial fly, and grows to a weight of six or seven pounds; and when taken, as it often is, in a salmon pool the angler is apt to mistake its strong surges for those of a small but sprightly 
salmon, until the absence of aërial flight enlightens but disappoints the rodster, who is absorbed and perhaps attuned to fever point in search of his first salmon.

Along the New England shores, particularly those of Massachusetts in Barnstable County and in the salt estuaries and bays of Long Island, on both the north and south shores, the river-trout will be found in salt water, remaining there for some months and returning to fresh water when the spawning instinct impels them. These fish also undergo to some extent the same change in form and coloration as prevails among the sea-trout of more northern sections, whose visits to fresh waters seems to occur only twice a year, once in the early summer months and again in the fall to spawn, after which returning to the sea and remaining there through the winter. In many northern localities, however, they are found in the bays and at the mouths of rivers during nearly the entire summer months, coming in and falling back as the tide ebbs and flows, and rarely ascending the streams. In Massachusetts these salt-water migrators are called "salters"; in all other sections, "sea-trout."

There are one species and four subspecies of 
the so-called trouts, which are recognized specifically as saiblings - the charrs of Europe, Salvelinus alpinus. These fish were originally found in the cold, clear lakes of the Alpine region and of Northern Europe, and, when subsequently discovered in America, they inhabited like waters, and will not thrive in any others. By the name of "saibling" they are universally known in Germany; in France as the "ombre chevalier," and in England as "charrs," and among American anglers the name of "trouts" without distinction of species is generally given them. The saibling is very thoroughly distributed in Northeastern America, and new varietal forms are not infrequently discovered in the waters of New England and Canada; at the present time the varieties are: the long-finned charr, the Greenland charr, the Arctic charr, and the Sunapee trout, in all of which the anatomical differences appear to be slight, but the coloration varies greatly.

The type of the saiblings, as we find them in American waters, is the "European charr" or "saibling," Salvelinus alpinus. It is either grayish or greenish on the back, and the belly is red, particularly in the male during the spawning sea- 
son; the lower fins are margined with a white strip, as in fontinalis, but unlike it, the back is not marbled or vermiculated. On the sides of the body are round, red spots and the scales are "infinitely little," hardly if ever seen by the ordinary naked eye, there being about two hundred of them placed along the lateral line from the gill covers to the base of the tail fin. All forms of the saiblings rise freely to the fly, if anything being more sprightly in rising and in their eagerness more frequently missing the feathers, than our brook trout. The ordinary gear and flies used in fishing for fontinalis will lure these saiblings, except the Sunapee trout, which are generally taken from deep waters by still fishing or trolling. But little is known of the three Arctic saiblings, the long-finned charr (Salvelinus alpinus alipes), the Greenland charr (Salvelinus alpinus stagnalis), and the Floeberg charr (Salvelinus alpinus arcturus). The first (alipes) is noted for its very high or long-rayed fins, for its forked tail and the very small size of the adipose fin; the second (stagnalis) for the dark green, with lighter green streaks, on the back, for its greenish upper fins and lower pink ones; the third (arcturus) for the absence of red or 
pinkish spots on the body. I have no authentic reports of the game qualities of these charrs, but doubtless they rise freely to the flies and resist capture bravely.

Perhaps no fish has been the subject of so much discussion as the Sunapee trout, and the pages that have been printed on the subject of its original habitat, whether native born, foreign, or a hybrid, would fill an octavo volume with pros and cons, and at the end of it all we would be no wiser. So close is the structure of the Sunapee trout to the other saiblings that Professor T. H. Bean was compelled to resort to its peculiar and beautiful coloration that an appropriate technical name might be found for it, although the coloration of a fish, by strict ichthyological law, is not a factor in classification. This trout is scientifically known as Salvelinus alpinus aureolus, alpinus being the specific title of the saibling, and aureolus, "golden." As it is commonly called by New England anglers and others the "golden trout," confusion, as I have before stated, is apt to arise owing to the similarity of name with that of the true golden trout of Mt. Whitney, California.

The Sunapee trout is only found, within our 
present knowledge, in Sunapee Lake, Dan Hole, Carroll Co., both in New Hampshire, and in Flood's Pond, Ellsworth, Maine. These waters are very deep and pure, and contain large numbers of landlocked smelt and crustaceans, upon which the trout feed to such repletion that they do not rise to surface food of any kind, certainly most infrequently, if at all, to the artificial fly; but on the trolling spoon, or live smelt in still fishing, they show grand fighting vigor.

Their coloration is resplendent in orange, brown, and golden tints; on the back a clear olive sometimes shading into brown prevails; the belly shows shades of white to orange, pink, and red, and in the spawning season, in the males, a dazzling and brilliant orange pervades the region below the lateral line. The distinguished structural markings of this fish are the teeth, which are present in a broad row at the base of the tongue; the small head, large fins, and bent form of gill-rakers; the absence of mottlings on the back also serves to differentiate it from the brook trout. The Sunapee trout is a good feeder, taking a live smelt preferably, but any other small fish with which the hook may be baited and lowered sixty to seventy feet; ground baiting for 
several days before fishing being most fruitful in scores.

The habits of the oquassa or blueback trout (Salvelinus oquassa) are somewhat similar to those of the Dublin Pond trout and the lake herring; they can only be seen in the lakes and streams between October Io and 20, after which they disappear until the same period of the following year. The cisco or lake herring comes to the surface when the May flies are swarming, usually for about thirty days, from May 20 to June Io, and the Dublin Pond trout during the same period. Would it not be well for our fish savants, when in doubt as to the strict classification of the trouts, with their slight and often perplexing similarities of structure, to give some consideration to their habits when these are constant? If this was permitted as a factor in classification, a pertinent query would be - Is the cisco or lake herring a trout, or is the Dublin Pond fish a cisco? Both are members of the salmon family.

The blueback seldom, if ever, grows beyond twelve inches in length; it has a more slender and graceful body than the brook trout, and its forked tail is a distinguishing mark of the species. 
The name "blueback" is taken from its color on the back, which is bluish black; the spots are red and round, and usually confined in location to the sides of the body; the head is quite small, more so than any other of the native trouts, and the scales are also very small, although close observation will show that they are larger along the lateral line. Mr. H. O. Stanley, Fish Commissioner of the state of Maine, states that the blueback is much hardier than the brook trout; that the spots are yellow, red, and black, and more brilliant; that he has "known them to lie on the ground all night and be alive next morning." They visit the streams in large schools, the same as the herrings and smelt, and spawn on the same ground as the brook trout. Their habitat during the balance of the year, from about November I to October Io, is in the deep waters of the Rangely Lakes, Maine, from which they are said to pass as the spawning season approaches from Lake Oquassa to the Kennebago River in large numbers, in obedience to the reproduction instinct. A short distance above its mouth the Kennebago receives the outlet of Lake Oquassa. The blueback leaves the Kennebago to the left and runs toward Oquassa 
Lake, where its bridal voyage comes to an end. About the middle of November it goes into Mooselookmaguntic Lake, and is seen no more until October of next year. The oquassa trout is not an angler's fish; a few have been caught in summer with the garden worm as bait, and they have been taken with the same lure while on their spawning ground, but they give the angler the impression that the bait only annoys them, and they attack it merely to drive it away from their beds.

There are two subspecific forms of the blueback trout: one the Naresi charr (Salvelinus oquassa naresi) with an Arctic habitat; the other the Lac de Marbre trout (Salvelinus oquassa marsoni), the latest discovery in the line of charrs, living in a lake of the same name as the fish and doubtless numerous other Canadian waters. The first (naresi) is distinguished by its very small red spots, greenish back, deeply forked tail, and deep red lower fins. It is found in Discovery Bay and Chamberland Gulf of the Arctic region. I have no record of it as an angling fish.

The Lac de Marbre trout is somewhat closely allied to the blueback trout, but grows to a greater size; it is readily distinguished from it by 
the large mouth, four teeth strongly hooked on tongue, and strong ones on lower edge of jaw for nearly its entire length, also by its coloration and deeply forked tail. It is dark brown on the back with an iridescent tint of blue, shading into whitish, tinged with yellow below the lateral line; the top of the head is blackish and the cheeks are silvery. There seems to be some conflict of opinions among anglers as to the methods of luring this fish. Some contend that it is a deepwater trout and will not rise to a fly, and this appears to be the case with the first specimens caught in Lac de Marbre; but in other waters they come to the fly and take it freely in the fall of the year, although none have been so taken in the summer months. It is said to leap repeatedly from the water when hooked (no other Eastern charr to my knowledge has this trait), and fights desperately. It is about a third larger than the brook trout, weight for weight, and grows to three pounds and upward. 


\section{CHAPTER VIII}

METHODS OF FISHING FOR TROUT - FLY FISHING AND

BAIT FISHING - UP-STREAM OR DOWN-STREAMATMOSPHERIC CONDITIONS - HOW A TROUT BROOK IS FISHED - THE GRASSHOPPER CAST - FLIES TO BE USED - DRY AND WET FLY FISHING - FLY FISHING AT NIGHT-FLIES USED IN LAKE FISHING

THERE are two accepted legitimate methods of fishing for trout, all others being barred by the ethics of the art. Trolling with a spoon or any other bait, and fishing through the ice are looked upon by the fly fisherman as coarse and unsportsmanlike, and they certainly are, when compared with the deft handling of a delicate cast of feathers. Trolling and ice fishing are merely yanking halfstarved trout from the water; fly fishing, born of skill and experience, lures the brook beauty to the surface by manipulating naturally the choicest morsel of his menu and causing it to fall upon the water, gentily fluttering, as a snowflake falls on a calm winter's day. Moreover, when casting an artificial fly, the angler by a gentle turn of the wrist seeks to impale the hook; in trolling the 
boatman finds the fish, and the trout hooks itself. When wading down a trout stream with its alternating rifts and brown quiet pools, the experienced angler gently drops the feathers atop the one or across the still bosom of the other; he knows the resting and feeding places of his quarry, and calls that knowledge into play every dozen steps he takes down the galloping and frolicsome stream.

The two legitimate methods of fishing for trout are fly casting and worm fishing with a light rod and delicate water gear. I am not so ironclad in opposition to bait fishing for trout as are many of my brother anglers. It is an art in itself, and a knowledge of the habits of the fish and of the stream in which it lives is as necessary for success as they are in fly fishing; and there are days when fontinalis will not rise to the surface. A trout taking the worm when cast on a light rod, must be handled as skilfully as when he is on a hook dressed with feathers. True, he is apt to fight deeper, but as he seldom shows his body when restrained by a fly rod unless forced to do so by the muscular angler, and, when hooked, never leaps in the air of his own sweet will, it is difficult to define the degree of pleasure experienced in the one method and not in the other. But just here 


\section{The Trouts of America}

comes in the æsthetic nature of the fly fisherman. $\mathrm{He}$ contends that he gets the greatest enjoyment from the beauty and seclusion of the environment of a trout stream, and that one potent factor in the delight of a trout outing, is the mere act of casting the fly and seeing the fish rise to the surface for it. He also abhors the handling and impaling of a squirming worm, and objects to taking it from the mouth, tongue, or from the gullet, where it is often found embedded.

Fly fishing for trout is followed by the great majority of anglers, and their methods of fishing a stream are somewhat diverse. In slow-moving waters, the best course is to fish up-stream, and in swift-running ones down-stream, being careful, as before stated, to make a detour when a likely pool is reached, and fish it from the lower end to its head. In fishing up-stream, the cast of flies comes quickly down on the current, which compels constant and fatiguing casting, but this can partially be avoided by directing the flies diagonally up and across. Trout in a current always poise with heads against it, and common sense suggests that they are less likely to see the angler below them, than when he is fishing down-stream; yet it may be with a trout's eyesight, as it is with ours, we 


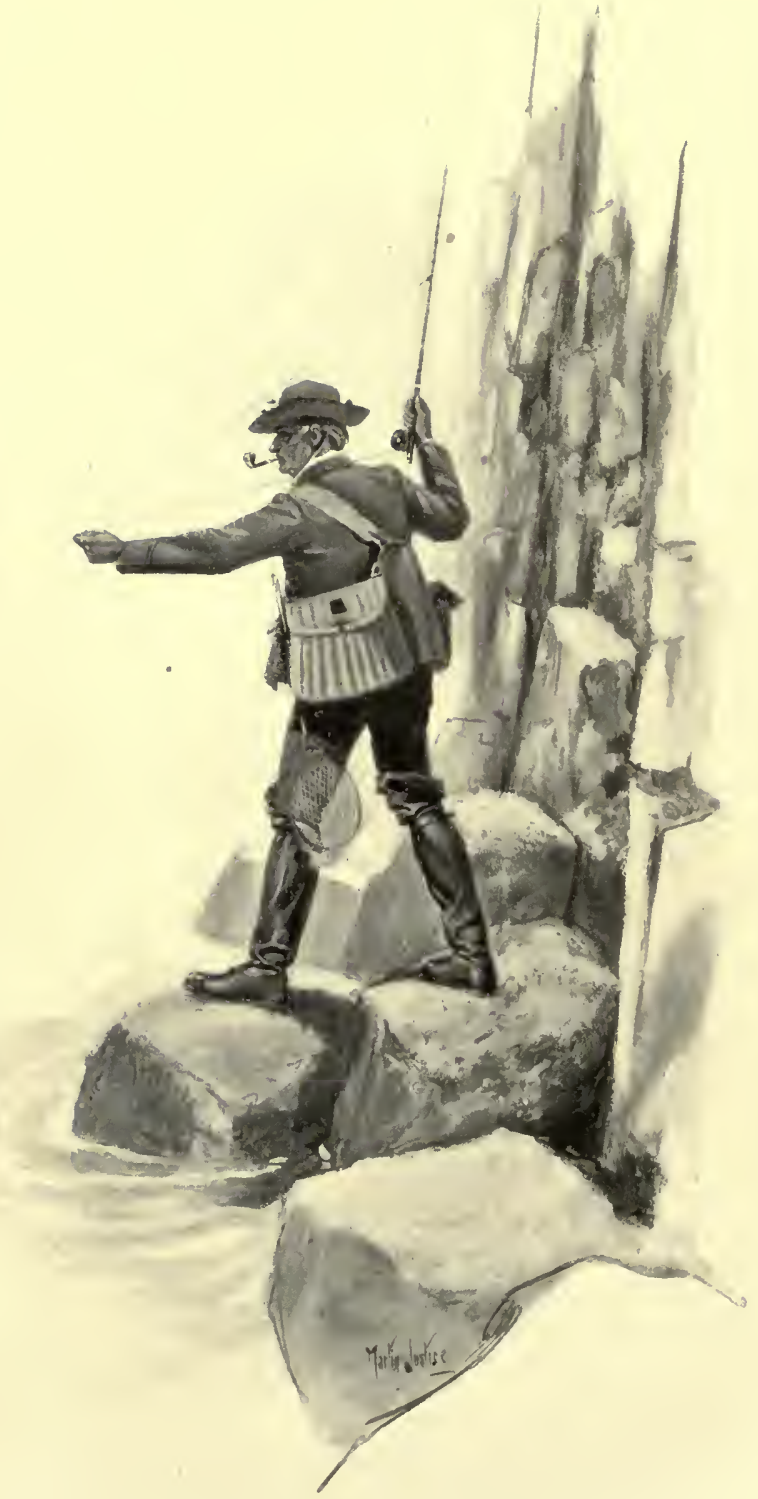

WHERE EXPERTNESS IS NEEDED 
cannot see far or clearly through an agitated surface of water, and it would naturally follow that down-stream fishing does not alarm the fish to the extent that it is credited to do. Certainly atmospheric conditions disturb or lessen the acuteness of sight in trout. On a bright day, with the sun rays illuminating every sand bar, rock, or pebble of the stream, the trout are timid, and will not rise to the most deftly placed artificial fly; but as the chasing shadows pass over the pool, causing dark patches, here and there, the trout in these shaded spots become alert for the drifting bug or falling insect. Under such conditions the experienced angler seldom fails to score, although when starting out the day appeared to be an unpropitious one. On dark days and at night trout, as a rule, rise freely; on bright days they are shy.

It has been, for a long period, a matter of discussion whether trout would rise during a thunder-storm or when an east wind is blowing. The pros and cons have been discussed until the subject ceases to be of interest, and has become about threadbare. It is, without question, a fact that these fish bite most freely when a rain storm is in its incipiency, when the first drops spatter upon the water; also 
that they are not alarmed at low, rolling volumes of thunder, but when it becomes more intermittent and resounds in sudden claps, the fish retire to the deepest holes that can be reached by them. This peculiar trait is easily understood and explained. When the thunder is low or deep, but regular in intonation, the atmosphere is not agitated with vibrations sufficiently strong to affect the surface of the water; on the other hand sudden and loud thunderclaps produce concussions that alarm the fish, causing them to scurry to a place of safety.

This subject of thunder-storms affecting the rising of trout, naturally suggests a few words on the effects of other atmospheric conditions. For instance, as to what wind is most favorable for trout fishing; a question that has been discussed since angling began as a pastime, and, as it appears, the east wind is most decried. In nine instances out of ten, when the angler is wading down a wooded trout stream, a strong wind changes its direction to almost all the points of the compass, whirling around bends, dashing through tree intervals, and circling in eddies, tempered or strengthened at every few 


\section{Metbods and Equipment}

hundred feet of the brook. Hence the decriers of an east wind have only the direct effect of such an air current upon the temperature of the water as an argument in their favor. A sharp, chilling east wind in the early days of the season, say in March or in cold April weather, is hardly a factor in lowering the temperature of the water, from which, in a tardy spring, the snow water has hardly run out and the partial chill of winter still remains. Later on, when the foliage is in its fulness of greenery, when the bees are buzzing, and the stream is in its normal fishing condition, it will require some days of constant northeast gales to lower the temperature of a trout brook, particularly if it is dashing, dancing, or rippling along its devious course over pebbles, boulders, fallen trunks, and other obstructions.

I never joint my rod when the air is chilled by unseasonable winds, not that their prevalence, unless continued for several days, will lessen scores, but rather from the feeling that fontinalis should only be lured when the air is mellow, the stream joyous in its flow, and the fish rampant in leaping and in full vigor of fight. No genuine trout angler can be responsive to the 
charm of the pastime when, in the cold days of early spring his teeth are apt to chatter, limbs stiffen, and fingers in their rigor, like bars of iron, fail in their firm grasp of the handpiece of the rod. And then, again, the trout, what sluggish, inert things they are! coming to the fly so lazily and sucking it in so leisurely that an angler, slow as a snail in striking, could never miss a rise or fail to impale the hook. But anglers, of all men, are most widely apart in opinion and practice. Some, whom I have known for years, and they are good fishermen, contend that an east wind is a favorable one, and that they never fail of success during a thunder-storm. Others, again, say they can never catch a trout during the prevalence of a northwest wind nor when it veers from the west to north, but a blow from northeast always fills the creel.

Trout seem to have an instinctive foreknowledge of a rise of water which will enable them to ascend with less discomfort and more rapidity to the higher reaches of the stream for the purposes of spawning; and that the rise will furnish them with a greater supply of surfacewashed food. Knowing this fact, experienced 
trout anglers often defer their visits to the stream until there has been a rise of water in it, and not unfrequently, when on an outing, the early morning salute to their host will be immediately followed by the query, "Did it rain last night?" The answer will determine the outline of the day's occupation - a delightful hour or more on the stream, overhauling of tackle, or reassorting the contents of their fly books, or the charm of swapping fish improbabilities with their fellow-guests.

Assured of the proper condition of the water, the angler approaches it with caution, having previously and carefully adjusted his tackle. Stepping quietly into the stream, either in the boil of a rapid or on the shallows near the bank, but never into or near a pool, his first cast will be up and across stream, the current taking the line and swooping it down; when at full tension it is allowed to remain in the water a few minutes. This is merely to get the lower gear in perfect working condition, although it should be nearly so before fishing if the angler has provided himself with a leader box, with its layers of moistened felt, and if he has carefully straightened out the snoods of his flies. After 


\section{The Trouts of America}

a half-dozen casts for this purpose, if there is a rift or rapid before him, he will cast about forty feet of line (a longer one is seldom necessary), being careful to place the flies on the lip of every little eddy caused by immersed stones, or larger ones made by protruding rocks - not forgetting that when "on the feed" trout are found in all portions of a rapid, wherever five or six inches of water comes tumbling down; hence fish every part of the boiling current. If a fish is hooked, it will be without warning, for the rise is not apt to be seen in the rough water; the first intimation of the presence of the trout will be the eager "pluck" of the fly, which on your part must be immediately followed by a turn of the wrist from left to right, a movement known as "the strike" in angling parlance. When a trout is fastened in rapid water he should be led, if possible, into a quiet reach and there killed, but if no still water is at hand, the fish should be held hard and killed quickly. He must not be allowed to cavort at will where submerged stones and rocks, some of them, perhaps, with sharp edges, line the bottom of the stream.

Descending the stream, the angler sometimes 
reaches a pool of several feet in depth, presenting a broad and still surface of perhaps twenty-five feet in length and fifteen in breadth. The "swim," as the English rodsters call it, will at times show a large boulder at its upper end, or a freshet-washed bank with an overhanging tree, the dirt-denuded roots of which lie beneath the surface and cannot be seen.

Under such a condition I usually make two or three long casts, placing the flies at the foot of the rapid, and at the spot where it subsides in gentle ripples on the surface of the pool. (The reader will kindly note in this connection that I am giving my own methods of fishing a trout stream, not those of other anglers, but few of whom fish alike.) After making these casts at the foot of the rapid, I leave the stream and walk around and below the pool, keeping at least twenty feet from the shore, and reëntering the brook forty to fifty feet beyond the foot of the quiet water, being careful, however, to fish above and below the entering spot, if favorable conditions exist.

When fishing a pool from below, long and fine casting, as a rule, produces the best results, and your flies should traverse every inch of it, particu- 
larly under the shelving bank, if such exists, and in the circling eddy below the big boulder at the head of the pool. Often I fish a pool from above before going below it, making the "grasshopper cast," of which more anon, but, in doing so, care is used in standing as much in the shadow as possible, or only casting when a cloud throws a passing depth of color over the pool; casting in bright sunlight is time wasted, although fifty to sixty feet of line may be used. Fishing the pool from above has frequently resulted in a good score, and thus encouraged I have often fished the same pool immediately after from below, making previously the detour described, and have frequently added two or more good fish to the creel. But the average best result is had from fishing a pool from the foot of it.

Here and there on a trout stream will be found, comparatively long, still stretches where only a gentle current prevails. They are, as a rule, of uniform depth, seldom reaching above the thighs. Such waters, I think, the most diffcult of any to successfully fish, but in them usually lie the largest trout living in the stream. Long and most delicate casts are requisite, and just here comes in the value of "the grasshopper 


\section{Metbods and Equipment}

cast" to which is attached a history which will be given briefly.

Up in Boone County, New York, there was a fine trout stream and a club of anglers. Its president was D. W. Cross of Cleveland, Ohio, now deceased. The writer was his guest at the club, and we fished always in company, often side by side, for the stream was broad. One day, on the brook, he said to me:-

"I know of but one man who makes the grasshopper cast as well as you do, and he is my brother."

"What do you mean? What is a grasshopper cast?" was the reply.

"Why, my good fellow, don't you know? there, you have just made one!"

Now I had been making the cast for twenty years, and was ignorant of the name and method of making it, but not of its merits; for it had taken many a hefty black bass for me years before out of the Schuylkill River. I can tell you what it is, not how to make it; it is beyond analysis and my power of description. It is a long throw, from the angler's standpoint, between fifty and sixty feet, and when the forward cast is made, the line first strikes the water at the spot 


\section{$34^{2}$ \\ The Trouts of America}

where the slight knot or loop attachment connects the reel line with the leader. Striking the water at this point, the leader is thrown upward and forward making a curve $\longrightarrow$, and the end fly falls very gently on the surface, followed by the dropper (I use only one), hence the name, "grasshopper cast."

The long, still stretches should be fished fine and thoroughly, particularly where the water has washed under the banks, and wherever there is a shadow thrown by an overhanging bush or tree. There, at midday, trout will be found avoiding the glare of the sun and reluctant, because of it, to forage, and appease the gnawings of a growing appetite.

In fishing at the foot of a fall or dam where the white water is foaming, the flies (dark ones) should be cast on a short line, say twenty to thirty feet, and as near the wood or stone work of the dam as possible, for trout often lie between the dam and the volume of down-pouring water; here and there interruptions may occur in this volume, which will enable you to get your flies beyond it. Don't be afraid that the trout will see you, if the extent of the foot space of the dam be small and the water is churning into flecks of foam. 
The habits of "rising trout" are apparently governed by their environment. In rapid streams they rise fiercely, seizing the fly with a dash and ejecting it at once when they find out its inedible nature, showing their sense of taste to be acute. Under such conditions the strike must be immediate, but gentle, and at the first sight of the swirl made by the eager fish; if you wait for the "pluck" or feel of the bite, you will, nine times in ten, lose your fish; he has ejected the steel and gone on his way, unsuspecting and unconcerned. If, perchance, this same trout passes down-stream to live a few days in a quiet and relatively deep pool, his entire nature seems to change; he is now a sedate, sober fish, feeding daintily on the insects falling constantly from the overhanging alders, rising very slowly to the fly and taking it leisurely, then turning a slow tail, and only feeling or tasting the non-edible thing it has mouthed after the turn of the wrist has fastened it into the flesh. Such fish are a glory to the slow striker. Hence, on the one hand, if you see the swirl made by the mad rush of a trout in the boil of a rapid, strike at once; on the other, go slowly, take a moment for consideration before the turn of the wrist is made, or else your fish 


\section{4}

\section{The Trouts of America}

will be lost; he has probably held the fly in the mouth loosely, being sure of its possession and too languid or indifferent to mouth it.

When a trout is fastened on the hook in a comparatively deep and still water, and if he is of average stream size, the spring of the rod, "its yielding resistance," will kill after you have him well in hand, being careful, however, that he does not rush into a root-hole, around a bottom snag, or in the thick water grass or lily pads. If he does get among the latter, don't yank, but keep a strong steady pull upon the line; and if that does not make him yield, sit down and wait, with a slack line, just like a mule driver sometimes has to do with his mule - he tires it out, or rather calls it into action, by inaction and patience. I know of no other methods by which an entangled line by a fighting trout can be released, unless the water be shallow and you wade out and gill the fish with your forefinger.

As the season advances, say toward August, examine the banks of the pools for little springs which are frequently found trickling down; at such points trout are apt to gather in pairs, preempting the spot to secure for themselves a cooler temperature, and the greater likelihood of drifting 
bugs on the spring water. Hesitate and examine the situation before approaching and fishing the pool. If trout are rising, note the form and general coloration of the insects fluttering over and falling into the water. Don't differentiate shades or tints of color, but scrutinize the shape of the body, and the general make-up of the insect. The trout may not be color-blind, yet we cannot believe that he can tell the difference in tint between orange and yellow, if you have such dressed on your fly-hook. Rather deceive him by the natural movement you give to the artificial, which, in my experience, is a warranty of good scores, if the fish be in a rising humor. In my opinion, form, not color, when properly manipulated, is the greatest factor in a big creel product; and a half worn-out, jagged fly, dishevelled, with wings or hackles all awry, leaving a discernible wake, not too heavy, behind it as it is trailed with a lifelike action over the water, is more seductive than those of spider form, a May fly imitation, or any other make of artificials, dressed however beautifully artistic they may be. This matter brings up the subject of flies generally used in trout fishing.

Many anglers, when stream fishing, string on 


\section{6 \\ The Trouts of America}

their leaders a half-dozen flies of variegated colors, alleging as a reason therefor that the captious trout has a wider range of colors from which to choose, hence capture of them is more likely to be effected. It is to be noted, however, that these fishermen are short-line casters, and fish the shallow rifts closely, but often successfully. Three flies constitute the usual cast of most trout anglers, and the general use of this number, no more or no less, cannot be explained satisfactorily, although many rodsters contend that a trio of flies attached at proper intervals to the leader can be played upon the water more naturally than a lesser or greater number; but it must be remembered that our feathered lures, as we manipulate them in fishing rapid streams, are extremely unlike living bugs in action or appearance, particularly when we draw the artificials up or across a five or a ten mile current, where a bug in life would have to possess the muscular power of a leviathan of the deep to maintain the position and action given by our restraining lines. I use only two flies, a practice induced no doubt by experience on a black bass water, where a couple of fish weighing upward of five pounds are a heavy test of a light fly rod. As my casts average, 
wherever possible, forty or more feet, I place the first and only dropper about three feet above the end or point fly, and by recalling the line, gently lifting the point of the rod just before the forward cast ceases, both flies fall upon the water at the same time, and before the reel line touches it. In making very long grasshopper casts this recall of the line is not necessary.

Thaddeus Norris, the author of the first systematic treatise on angling in American waters, published thirty-eight years ago, has ably covered the subject of flies to be used, and the manner of handling them; in fact, has given us the science of the art in a couple of terse paragraphs. It would be well if his words rung in the ears of every angler when on a trout stream or preparing to go there.

"Don't bother with a lot of flies. Here are four that will serve all purposes: one is the Red Spinner; the second a Black Gnat; the third is the Coachman; the fourth and the best of them all is the Red Palmer or Red Hackle, as it is indifferently called.

"Now for the secret. Take the Red Hackle as the standard and you will understand. If you throw it out and just drag it on the water, as most 
people do, what do you suppose a trout will take it for? Why, just what it is - a bunch of hair, no more, no less. You drag it along, and the hairs close on the shaft of the hook; it is just a dead mass, not resembling a fly, or a caterpillar, or anything else. But suppose, instead of this, you work your wrist very gently up and down, so as to let the electric hairs of the hackle expand and close with the stream; what then? Why the thing looks alive, looks like a drowning insect, and the trout goes for it directly. It is the same with winged flies exactly. There is no use having wings to a fly if you simply drag it through the water in one direction."

"Uncle Thad," as he was familiarly and lovingly called by his contemporary stream anglers, was evidently neither a "formalist" or "colorist" in the matter of flies, but put his faith in the proper manipulation of the feathers on the water, as all good and worthy anglers do in the present era, a halcyon one for "the art contemplative," and its devotees, for skill and experience are now the primal factors of a full creel.

We sometimes hear the phrase "cocking a fly." It is a term used in England to express a cast that puts the artificial fly in a natural position, 
that is, floating on the surface with its wings up or "cocked." Many English-made flies (American also) are dressed with upright wings, and to put them on the water "dry" is a killing practice, particularly on streams that are much fished. To place artistically a cocked fly on the surface, a horizontal cast seems to be requisite, as the overhead method is apt to topple the fly over on its side. It will be noted that a cocked fly, as above stated, should be cast "dry." This leads to the much-discussed subject, particularly in England, of the merits of dry and wet fly fishing.

Fishing with a dry fly is more in use in England (with one fly only) where the streams are somewhat sluggish, than in America, although a few of our experienced anglers have practised it for many years. The process is simple, as it consists in merely switching the flies a half-dozen or more times in the air, before placing them on the water. It is practised with greatest success when fishing a pool from below, but is practically of no value when fishing down-stream in wild water. The flies and lines in use for dry fishing have been somewhat elaborated; both are frequently well oiled to increase their floating quality, and the flies are made with corked bodies 
and with wings of fish scales for the same purpose. An English writer thus sums up the merits of dry-fly fishing:-

"It is certain that no more delicate and skilful method of capturing a created thing, no more difficult exercise, has ever existed, than that of dryfly fishing. It is not only the nicety of the operation at the time of casting a single fly so that it alights, whatever may be the difficulties of place or wind, in a particular spot with complete certainty and proceeds to float down over a rising trout with wings erect and natural motion, but there is also the beautiful perfection with which the insect is imitated by the fly-dresser, and the lightness of the tackle to which it is attached."

Fishing for trout with the fly at night has become quite a fad with many anglers, and, as a rule, so killing is the practice in the East that the laws of New Jersey prohibit it from 9 P.M. to daylight. Dark nights produce the best results, but before the moon rises and after it sets are also likely hours. The methods followed are similar to those used in day fishing, although, strange to note, dark flies are equally as fruitful in scores as light ones, particularly when casting into the foam of a fall or dam. When the stream is 


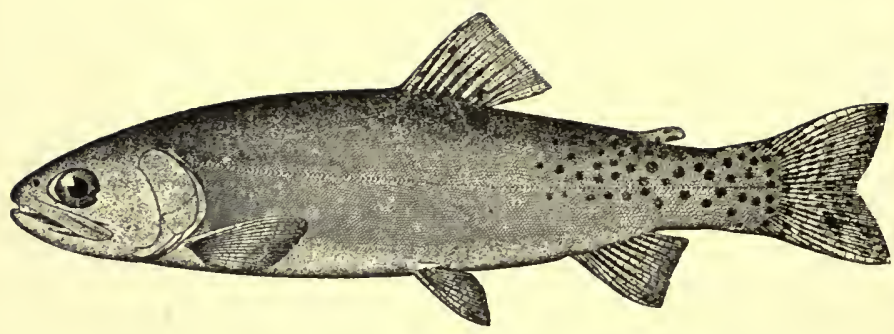

THE CUT-THROAT, OR WAHA LAKE TROUT

Salmo clarkii bouvieri

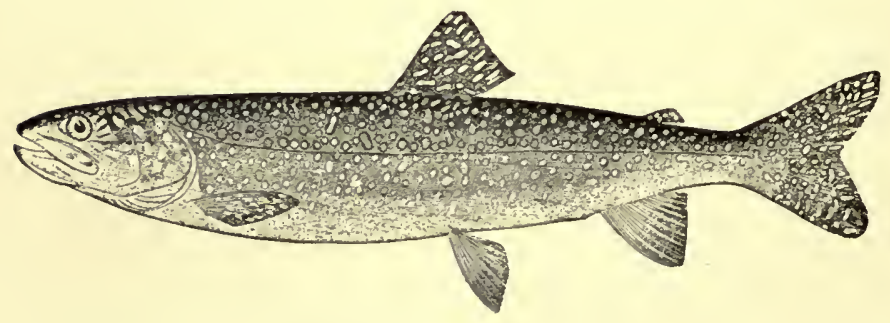

THE GREAT LAKE TROUT

Cristivomer namaycush

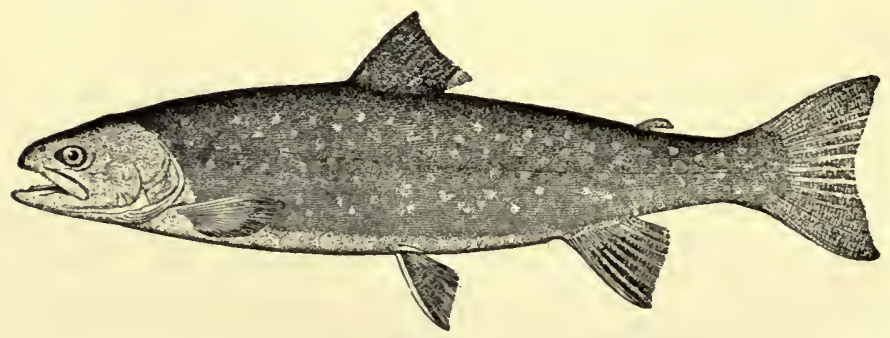

THE DOLLY VARDEN TROUT 
low in midsummer, the best results are obtained at night, which is the reverse of what the angler gets when fishing the same stream during the day. The rod should be at least seven ounces in weight and the water gear of greater strength than that used in day fishing, as you cannot give your fish any leeway in a small and blackened pool, perhaps lined with water grass and overhung with bushes, the outlines of which you can hardly see. The trout are bolder, naturally, at night, and come to the fly with an eager rush; and it seems as if all the senses they possess, except that of taste, were quiescent or lacking acuteness. Notwithstanding, you must strike quickly at the first feel of the "pluck," or else the fly will be ejected. Larger flies should be used than in the daytime; the splash of them on the water attracts the trout, who seem to be on the qui vive for falling insects of large size, particularly grasshoppers. The most delightful fishing for trout I ever had at night was when using a large Black Hackle tied on a No. 4 Limerick hook. I took eighteen fish that averaged over half a pound. The trout evidently mistook the Black Hackle for a cricket, for passing along the stream by a path that led close to the bank, a few evenings subse- 
quent, I noticed, at the pool which I had fished, overhanging bushes, which were brushed with the shoulders as I trudged campward, and from them black crickets were jumping and numbers of them falling into the water.

In many waters, particularly the smaller streams of New York and other Eastern Middle states, large, gaudy flies are not the most alluring, and knowing anglers use sombre-colored ones, such as the Alder, Gray Drake, Cinnamon, Cowdung, Yellow-bodied Professor, Coachman, and others similarly dressed. The wings and tails should be small, and the reds, yellows, and greens of subdued shades. A very killing artificial on any trout waters and in all sections, I have found to be a nondescript without a name, although it is somewhat similar to a tailless Professor. It has a dull yellow body with one spiral winding of black silk; very small brown, gray, or cinnamon wings, with little white spots on them; no tail, and it is tied on a No. I4 Sproat hook and even smaller ones. I have found flies, almost minute, dressed on hooks Nos. I8 to 22 to be killing, when all others failed to allure. They are particularly serviceable when, as the shades of evening thicken, the trout are seen leaping and evidently 


\section{Metbods and Equipment}

feeding on midges or mosquitoes, and large flies tied on Nos. Io to 12 hooks fail to attract them.

When fishing in lakes large, gaudy flies are generally used - those tied on Nos. 4 to 8 hooks and of such patterns as the Silver Doctor, Parmacheene Belle, Montreal, Coachman, Lord Baltimore, etc. When moving in the boat from place to place, a deep troll with large flies is often successful. 


\section{CHAPTER IX}

CASTING THE FLY - HOW IT IS DONE - THE SWITCH OR SPEY CAST - HANDLING A HOOKED TROUTBAIT FISHING - SELECTING FISHING TACKLE, RODS, REELS, LINES, LEADERS, ETC.

THE art of casting a fly cannot be taught either verbally or by written instructions. Diagrams will not aid the tyro, nor daily and studious visits to a fly-casting tournament. The first is too rigid to even indicate the supple action of the wrist of the caster, or the graceful flow of the line from the tip of the rod; the latter outrages all principles of the art by the strenuous efforts of the contestants to shoot the flies to the outermost reach, and in doing this their gyrations and often grotesque attitudes place a libel and a disgrace on the gentle art of angling. The young angler must be patient and observing, and seek for every opportunity to accompany an experienced fly-caster on the stream. Let him be content for days to use bait and follow his fly-fishing companion at a distance of several hundred feet, all the while with his eyes open and his intelligence at work. 
My first attempt at casting flies, over half a century ago, was under peculiar conditions. I had followed Horace Inskeep, a veteran angler of Philadelphia, for a week or more down the streams with a fly rod and fly-fishing water gear in use, but with a garden worm as bait. One day, when the stream was high and I was alone upon it, the strap holding the box of worms became loose, and was engulfed and carried down by the swollen, though comparatively clear waters. The dilemma was perplexing and annoying; but in a few moments I chanced to remember that a fly book, which I always carried well stocked but had never used, was in my coat pocket, and, then and there I rigged up a cast of flies and have never used bait since that eventful day. Close and daily observation for over a week of Brother Inskeep's methods had imparted "the knack," and I placed the flies measurably well at the first cast. It is entirely a knack, and a tyro must catch it quickly or not at all. I have seen a youngster cast a fly cleanly upon the water on the first two or three attempts; and then, again, I have noted that some contestants at tournaments, with their output of seventy-five to ninety feet, are lacking in the first principles of the art. The 
power to cast a long distance is with them muscular, and their use of the muscles of the entire arm is distressing to the stream fisherman.

But if the art of casting a fly cannot be taught by printed instructions or by word of mouth, a hint or two may be of use; for instance:-

Let the young angler make his first attempts in the current of the stream with a line that is slightly longer than the rod. When the line is down-stream and at full tension, a gentle spring of the tip of the rod, made by raising the hand piece an inch or two, and at the same time giving a quick turn of the wrist from left to right (a movement that is, or should be, involuntary), and then quickly lifting the rod so that the tip will be slightly behind the right shoulder, will effect what is called "the back cast." As the rod reaches the shoulder position a pause of one to three seconds, to allow the line to extend backward, must be made, and the rod then sprung to the front as described in the backward movement; this is called "the forward cast." The spring of the tip of the rod should be snappy, but not violent, and just how to do this and allow the proper lapse of time before making the forward cast, constitute, I think, the main difficulty in 
acquiring a correct casting style; and even when learned must be constantly practised before perfection is reached. Many stream fishermen swing their rods back and forth, using their entire arm in the movement, and manage to get their flies some distance on the water, but they fail sadly in accuracy; and this quality, only to be acquired by the method described above, is essential to filling the creel. An old stream fisherman should be able to place his flies at a distance of forty to fifty feet within the circle of a silver dollar, five times out of six, and send them out of his sight, around the projecting angle of a rock, shore-fastened at a bend of the stream, provided, of course, the wind is not unfavorable; but to reach this high mark of excellence and accuracy, the angler must have years of experience in actual stream work.

Some years ago, when fly-casting tournaments were more frequently held in public, the switch or Spey cast became popular, but is not so much so at the present day, although every angler uses it, in a modified degree, when a requisite back-cast is prohibited by the presence of wood or brush growth on the banks or other obstructions. It is made as follows. With the line at full stretch down-stream 
and the hand grasping nearly the extreme end of the butt, the rod is raised so that as much of the line is cleared from the water as possible, then a forward stroke is made sufficiently strong to lift the entire line from the water and to cause the fly to alight a short distance in the rear of the caster; then, placing the rod well back, as in the forward cast of the ordinary method, a strong switch of the rod to the front will cause the line to roll out rapidly; the leader and flies, as the line goes out, making a leap as it were and alighting upon the water in the manner of the grasshopper cast before described.

The ambitious tyro, after he has caught the knack of casting and become master of his rod, will learn from stream experience the varied casts known as the left-handed, the side cast, the under cast, the horizontal, etc. The necessity of the use of them depends entirely upon the character of the stream, and it is when fishing one that the angler is brought face to face with their value, and can quickly acquire a knowledge of them. Words would be wasted in an attempt to describe how the casts are made.

When a trout is fastened on a fly rod, it should be brought to the net as quickly as possible. 


\section{Casting the Fly}

Humanity alone would prompt this, for if the trout does not feel pain, because of the impalement of the hook in the jaw where a minimum of its nervous system exists, it certainly must suffer in a degree, and not a slight one, from enforced captivity, the final result of which he evidently fears will be death. Why else his frantic struggles to escape? Besides, a trout quickly killed and creeled will retain its natural color and the choice flavor of its flesh much longer than one dallied with on a springing rod. To bring a trout quickly to the creel, it is not necessary to yank him incontinently out of the water, for the strain of the tense arch of the rod will soon bring him to the exhaustion stage, when he can be quietly netted, killed, and creeled; albeit he may recover suddenly when seemingly exhausted, and make a final struggle to escape from your hand, as you take the hook from his mouth.

In playing a hooked trout you must feel him constantly; your rod with its elastic give and take quality will greatly aid you in doing this. When necessary, as a trout runs toward you, which infrequently occurs, back away and reel up rapidly; and when you have him well in hand, and the line is retrieved on the reel to a little more 
than the length of the rod, slide the net under him at the first sign of exhaustion. Above all things keep cool, and play the fish without flurry. Our old master of the craft, Izaak Walton, nearly four hundred years ago, said to Venator on the stream :

"Why, now, let me tell you, you lost that fish by your own fault, and through your own eagerness and haste."

Bait fishing and fly fishing, as I have written, are alike legitimate and sportsmanlike. The advocates and followers of the first method are fully equal in number to those of the latter, and when we hear the remark, as not unfrequently happens, "Oh! I never fish with bait, $I$ always use flies," uttered in a tone consequential and somewhat contumacious, we can discount the speakers' qualities as a man, and put a low estimate upon his skill as an angler; a good and gentle one never brags or holds himself above the humblest of the craft.

When fishing for trout with bait, a fly rod with light water gear should always be used; in fact, the tackle should be in no manner different from that handled in fly fishing, except the substitution of a single hook for the feathers. Fishing with 
bait down a stream for several seasons gives substantial experience to the future fly fisherman. He will acquire a thorough knowledge of the water where the trout lie, their hours of feeding, when on the rifts, and when in the pools; the situation of the bottom and surface flowing springs near which the trout love to lie; the character of the banks, the trend of the trees and bushes, where the boulders, logs, and other obstructions are located in the current, and last, not least, if he has the true instinct of the fly fisher to be developed in the future, he will note all the phases of insect life fluttering over and born of the water or on the overhanging bushes.

The bait fisherman will find no difficulty in catching trout when a qualified freshet is on a slightly clouded stream. A fly-fishing rod and tackle, with a No. 6 Sproat hook, baited with a moss-scoured garden worm, which is to be allowed to trail down the current, guided here and there, to the most likely places, will usually fill the creel, if the fish are there and on the feed. But on a bright sunny day, when the water is low, a different finale is apt to occur. Under such a condition, the bait fisherman must bring into play all the caution and finesse of the fly-caster 
to insure success, and he is mainly handicapped by the frequency of his hook catching on the bottom, compelling him to disturb the water by wading into it to release the hook.

We now reach the subject of the outfit of the angler, or to use a more modern and comprehensive, but from a phonetic standpoint, rather inapposite, term, his impedimenta, the rod, the line, the hooks, baits natural and artificial, and camp equipage generally. Of flies we have treated in previous chapters and in the succeeding one. Of the rod I feel impelled to say to the young trout fisherman as I recently did in Outing:-

"In selecting a rod, choose one that fits you best. Select it as you would a coat, a pair of shoes, or a cane to walk with. You select those because they fit you, and you feel at home in the use or wear of them. Does the rod fit you as you swing it into the air? Does it balance well in your hand, or is there a catch or interruption of the harmony that should exist between you? If so, discard it at once. Many anglers assert that if a rod don't fit them, they grow to fit the rod, that while they prefer a stiff one (or vice versa), they work into a whippy one, and do good and pleasing execution with it. This will do very 


\section{Casting the Fly}

well for the old hand, who has become sun-dried in all the 'tricks of the lure,' and can deliver a fly daintily fifty feet from the end of a bean pole, but young anglers should take heed. Time and application only can make a perfect angler, if such there be, and there is nothing that will act so thoroughly as a set-back to the tyro as a rod out of joint with the man who uses it."

In selecting your fishing tackle for the first outfit, and until you have found by experience what is best for your use on the stream, you will necessarily have to depend upon your tackle dealer, hence be careful in choosing one that is entirely reliable, and who is also a fly fisher from love of the pastime. When purchasing a rod, tell him that you want one of six ounces and not over ten feet, made in what is now called "tournament style," a strong caster with plenty of the springing quality, but with corresponding backbone. This will answer both for bait and fly fishing. A good, hand-made split bamboo will cost twenty to thirty-five dollars, but you can get one turned in a machine for from sixty-nine cents to fifteen dollars; the lower-priced ones are worthless.

When selecting a reel, examine its mechanism, 


\section{$364 \quad$ The Trouts of America}

which is most durable when least complicated; hence place no confidence in novel and intricate reel devices until fully tried on an outing. The eye may be pleased, and the judgment seduced by an attractive, and apparently practical, "throw off"; a peculiar click device, a new thumb button for a drag, or a non-revolving handle - all of which may be placed before you, if not recommended, by the dealer. Hence, be careful in your selection, and do not hesitate to ask your older angling friends as to the qualities of a reel that may have attracted your attention. See that the spool of the reel which you select revolves freely and smoothly, without jar or clatter; that the rivets and screws fit tightly; that the reel plate lies snugly in the reel seat of your rod; that the cross-bars are securely riveted, or screwed, and at proper distances apart; that the click sounds full and clear, which is measurably an indication that the mechanism is well put together and the material good. For either fly or bait fishing for trout, the old-fashioned, simple click-reel, holding thirty yards of line, is the favorite among anglers, and I have never used any other on a trout stream. However, the automatic reel is much liked, and such old anglers as 
Reuben Wood, and others, used and highly recommended it, but many fly fishers are so built, that they want to give the trout all the chance it has for liberty, after being hooked, and the automatic reel does much of the work, particularly in retrieving, that is incumbent upon the angler to do, if he is in full sympathy with the fish that he has fastened. If he is not, he goes afishing merely for the pleasure of killing something, just as we sometimes see children, having a similar instinct, kill flies on the window-pane in the gloaming, for the sport of it.

In selecting a line you cannot go astray, for the enamelled silk waterproof is the best you can get, both for bait and fly fishing; you will want not less than thirty yards of the size known as "E."

In buying leaders, select those that are made of the best gut; the strands should be perfectly round, and transparent, and colorless as glass; "it should be hard to the teeth, and free from unravelled fibres and knotty roughness." I quote the words of an old angling friend who knew what he was talking about. For fly-fishing purposes I use leaders of nine feet, but for bait fishing, six, or even three, feet will be a sufficient length. 
There is said to be over two thousand artificial flies, of various colors and forms, including the nondescripts, used by anglers in both hemispheres. To acquire even a knowledge of the names of these would entail hard study, and when acquired, would be more ornamental than useful. To become familiar with their comparative killing qualities, the best hours and seasons for using them, the atmospheric condition under which they are most effective, their integral make-up, with their multitudinous shades of color, would entail years of application, and constant intercourse with the members of the craft, many of whom evolve a new combination of feathers every time they visit a trout stream. As before intimated, the tyro should enter upon his novitiate with a few dozen standard flies in his book; selecting hackles tied palmer fashion, and winged flies of contrasting colors.

Natural and artificial baits for trout are of many diverse kinds. Of the natural, the common garden worm and the live minnow are the most enticing. Of the artificial, the phantom minnow for trolling, or use in rapid water, is the only one that gives satisfaction, according to the experience of many excellent anglers, who sometimes 


\section{Casting the Fly}

forget themselves, and go atrolling for our beloved fontinalis.

Of the many makes, sizes, and trade-marks of hooks three seem to have gained prominence and favor with the majority of anglers - the Sproat, Limerick, and Carlisle. Among fishermen who follow fresh-water fishing exclusively, opinions are divided as to the relative values of these makes, and I am inclined to say to the young angler: "Don't bother about names of hooks, or split hairs over angles of draft. All the makes named above will catch a fish cleverly, if firmly hooked and properly handled." 


\section{CHAPTER X}

\section{HOW TO TIE ARTIFICIAL FLIES}

To make one's own flies is not only an accomplishment, but often a neccessity. Occasions arise when an angler exhausts his supply of a certain fly at which the trout are rising eagerly. This frequently occurs on the stream and is a sad mishap, if the rodster has not taken with him a few loose feathers, a small spool of silk, a skein of colored floss, and a piece of shoemaker's wax. How to tie a fly must of course be learned at home; but when on the stream, this knowledge enables the fisherman to quickly dress a fly, crude though it may be, that will answer the demands of the hungry trout.

I propose, briefly as possible, to state how the angler may learn the art of fly-tying, the material necessary to use with a description of the dressings of most of the flies in use on trout streams.

At the beginning it is well to provide yourself with a tin box in which to keep materials to prevent them from being scattered about, and per- 


\section{How to Tie Artificial Flics}

haps lost. I use a tin cash box, $7 \times 10 \times 4$ inches, and find it answers very well.

The next step is to lay in the necessary tools, consisting of a small jeweller's vise, with jaws not exceeding a half inch in width, the vise having an attachment to fasten it to the table; a pair of sharp-pointed embroidery scissors, a pair of long pointed pliers, with a small steel stiletto, completes the list. If you find difficulty in obtaining the small stiletto, you can substitute a large needle, and you might also add to your stock of tools a pair of

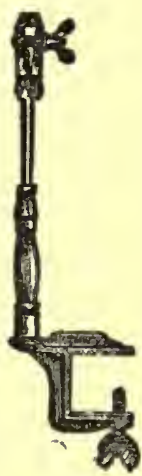
VISE. spring steel nippers (apply to your tackle dealer for them), although I seldom use either of these tools.

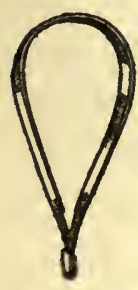

PLIERS.

As to materials, you should obtain a supply of Sproat hooks of assorted sizes, and some silkworm gut; a skein or two, each, of several colors of silk floss (which should be waterproof, if possible); and a like quantity of many colors of fine chenille. These, together with a spool of ordinary sewing silk, is about all you will need in the way of materials, outside of feathers, to begin work.

At almost any of the poultry stands in our 
large markets you will find at least one employee who saves all the hackles he can obtain, as he has probably long since learned their value to fly-tiers, and often makes quite a tidy little sum over his weekly wages at the expense of very little time and trouble. The feathers you will need for a beginning are inexpensive; a few cents is all they should cost. Red and white hackles, - those from the neck of capons and game cocks are the best, but it is advisable to get as many varieties as possible, as no fly can be made without these hackles. You will also need some colored tail feathers from turkeys and pigeons, while the mallard duck will furnish you with some desirable feathers from his gray breast and a few dark brown shaded ones that grow on the body just back of the shoulders. All these will be found useful, as well as some from the guinea hen, and some white and assorted chicken tails.

Now that your stock of feathers is in hand, it would be well to visit your fishing-tackle dealer and ask his assistance in getting some gold and silver tinsel and mohair in various colors. The latter you will not need at the start, but will find use for it later on. These, together with a small piece of shoemaker's wax, will be all that is 



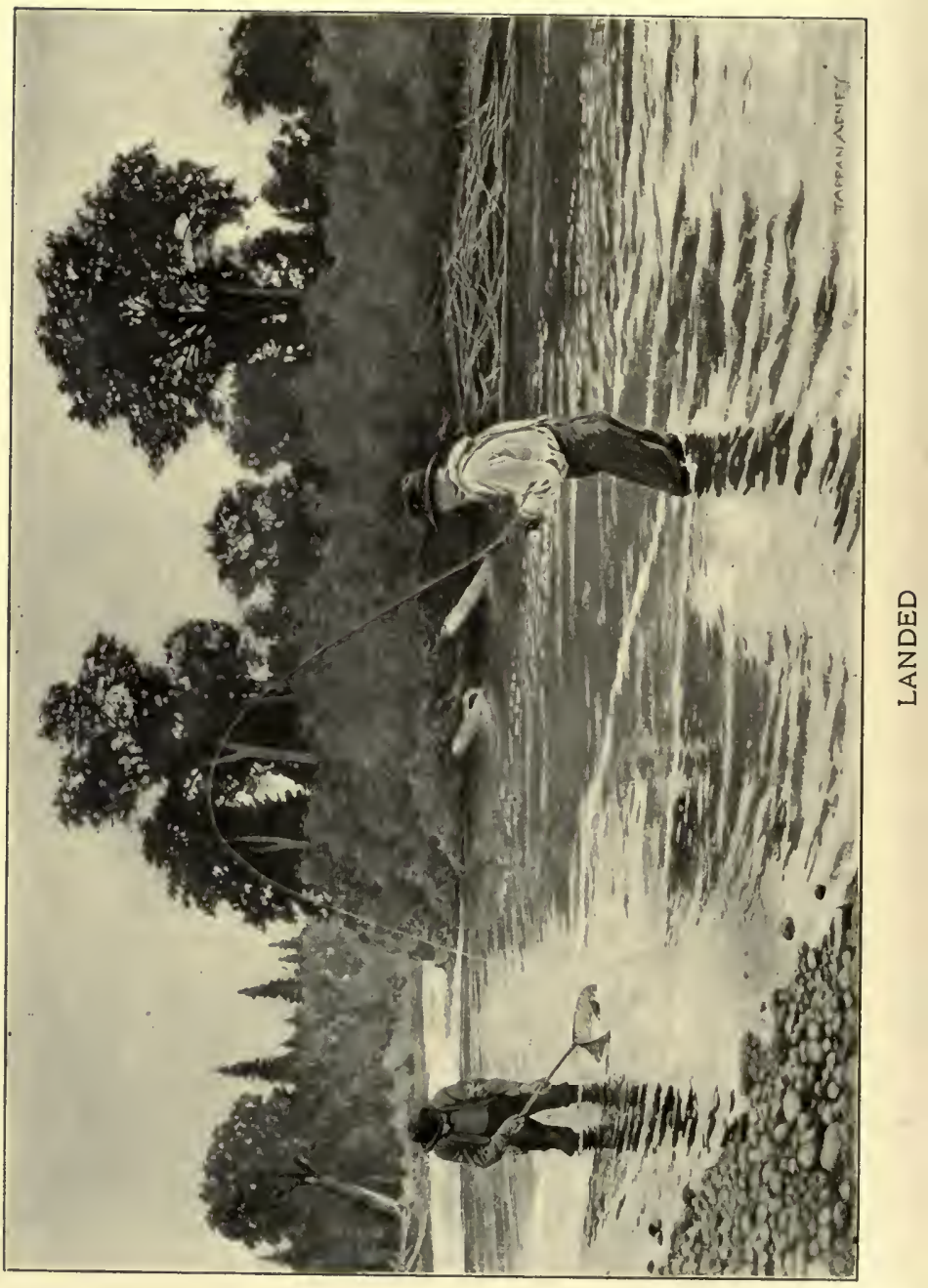


necessary to commence with; but after you have mastered the art, many suggestions of little odds and ends will come to you that will be useful. Cultivate your tackle man; if he is unselfish and kindly disposed toward you, he can assist in many ways and help to obtain the many little things, such as scarlet ibis, wood duck, and blue and yellow (dyed) swan, or egret feathers, which you will need later on.

As the description of different flies will call for green, scarlet, crimson, or some other dyed color, you will be obliged to dye some, or pay your tackle dealer a good price for them.

As it is no harder to make the reversed or turned-back wing, than the plain winged flies, and as they have a much better appearance, we will begin with that style of wing. The "light Montreal" is a simple fly, therefore a good one to begin the first lesson. Its description is as follows: tail, two or three fibres of gray mallard; body, scarlet silk floss ribbed with gold tinsel; legs, scarlet hackle; wings, gray mallard. If the description of a fly does not say how a hackle is tied, it is always understood to be tied at the shoulder only.

Fasten your vise properly to your work table, 
and place in it a No. 8 Sproat hook with the shank pointing toward the right. (This size hook is a very convenient size to work with.) The hook should be seized in the jaws of the vise by the bend only. Now break off from twelve to fifteen inches of your binding silk, and wax it thoroughly with your shoemaker's wax by drawing the thread over it eight or more times. You can do this better by folding a small piece of leather, and, placing your wax in the fold, draw the thread over it. The pressure of your thumb and fingers while holding the leather will wipe off all superfluous lumps of wax that adhere to the thread, and leave it nice and smooth. This method has another advantage in keeping your hands clean of the wax, as the feathers, silk, and

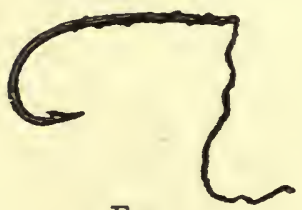

FIG. I. other materials would otherwise stick to the fingers, or other portion of the hand.

Your thread now being properly waxed, give it five or six turns around the hook, being sure to carry it up to the extreme end of the hook as in Figure I. This is contrary to all methods of the professional fly-dresser, as it is his custom to leave a little space at the end of the hook, but it is just 
at this point that the gut generally breaks, and if a wrapping or two of thread is placed between the gut and the hook, it will act as a cushion and prevent the gut from chafing on the sharp end of the shank.

Now we are ready to lay on the gut, which should have been soaked a few minutes in lukewarm water, and bind it on with the binding silk, all the while keeping quite as much strain on the silk as it will stand without parting. The gut, owing to its having been soaked, will be soft and the strain on the silk will make little indentations in it, and these, together with the sticky wax, and the few turns of silk between the gut and the shank of the hook, will hold it firmly. It would be well, however, to test it by giving a strong, steady pull at the gut after it is fastened on.

Before you put on the last two or three turns of the binding silk, place the end of a strip of tinsel, two or three fibres of gray mallard feather, and the end of a short piece of silk floss so that these last wrappings will fasten them. The floss should be prepared first by untwisting it. As silk floss is only of two strands, this is easily done by parting the strands at one end and separating them, and then lay together again with- 
out twisting. Your work at this stage will have the appearance shown in Figure 2.

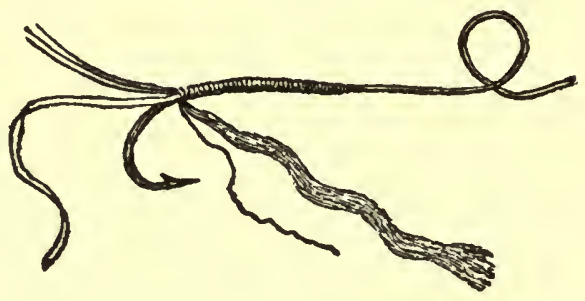

FIG. 2.

Now take a gray mallard feather and lay its convex side up, with the end extending out over the snood, and wrap it on with the binding silk as in Figure 3. This feather should extend out

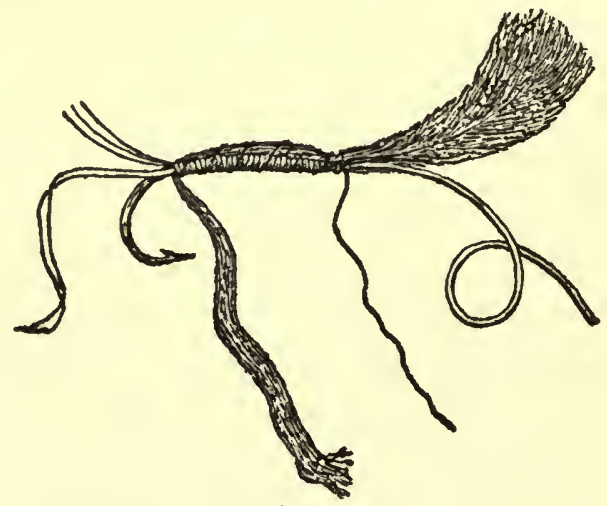

FIG. 3 .

over the snood far enough to allow it to reach the bend of the hook, when it is turned back for 


\section{How to Tie Artificial Flies}

a wing. By laying this feather on and wrapping it the full length of the body, it fills out the body and takes the place of wool or some other material that otherwise you would have to use.

Next take the end of your silk floss and wind it, without twisting, around the hook, making the

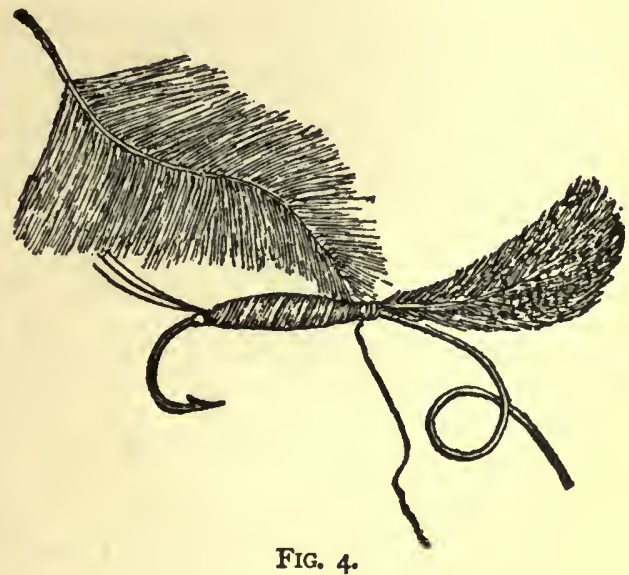

body of your fly of good shape by giving an extra wind where necessary. Stop about an eighth of an inch from the end of the shank to allow room for legs, and fasten it by two or three turns of the binding silk. After this wind your tinsel over the silk, first giving it two or three turns around the bend of the hook and fasten it by a turn or two of the binding silk. Now take 
a hackle feather, which for this fly must be dyed scarlet. Hold it at the extreme point by the thumb and finger of one hand, and with the other thumb and finger stroke down the fibres of the feather toward the butt, thus leaving the point standing out by itself. Catch this point now to your fly by a couple of turns of the binding silk, and your work should look like Figure 4 .

We have now reached the point where the most difficult work of fly-tying begins, that of

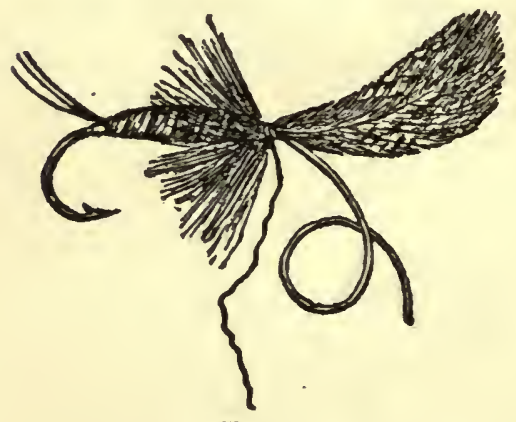

FIG. 5. putting on the hackle properly. Take your hackle feather by the stem and wind it once around the hook; wind from you. Then with your left thumb and finger smooth back toward the bend of the hook the part that is wound. Hold it in that position and give your hackle a second turn, then repeat the holding back process and another turn. Continue this until you have sufficient hackle on to form the legs of your fly and fasten the end by two turns of your bind- 


\section{How to Tie Artificial Flies}

ing silk. Now pick out with your stiletto the fibres that have been wound under and cut off the end of the feather not used, giving four or five turns with the binding silk to hold it securely. At this point your fly should look like Figure 5 .

If your hackle does not wind on evenly and too many fibres are wound under, unwind it be-

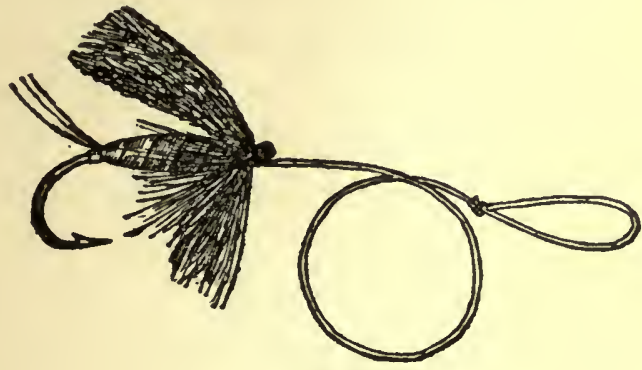

Fig. 6.

fore you cut off the end and rewind it, and you will find it will go on all right. This winding of the hackle will need more practice than all the rest of the work. Now turn back your wing to its proper position, give it one wrap of the binding silk and two half-hitches, and your fly will be complete as in Figure 6.

When the work is finished, put a touch of shellac to the knot to prevent it from slipping 
and to make it waterproof. Don't tie your binding silk at all until the fly is finished, then put a couple of half-hitches only, for if you have put a proper amount of shoemaker's wax on your binding thread you will not need any knots, as when you drop the thread at different stages it will stick of its own accord and not become loose.

We will now try an ordinary brown hackle or palmer fly with a red silk body. Wrap on your snood as before explained, and carry your binding silk well down to the bend of the hook. Attach a short piece of gold tinsel, and after giving it two or three turns around the bend of the hook, fasten it and cut off the end. This tinsel is not absolutely necessary, but a slight show of the bright metal at the end of the body of all flies gives a finish and makes a better-looking lury.

Prepare your hackle (a brown one) by stroking back the fibres, so as to leave the point free, and fasten it right above the tinsel. Then, after having fastened a piece of red silk next to the hackle (the silk should be split as described before), carry your binding thread forward to the end of the shank. This may be accomplished by giving it two or three turns around the body. 


\section{How to Tie Artificial Flies}

Now wind the body with the silk floss, being careful to stop about one-eighth of an inch from

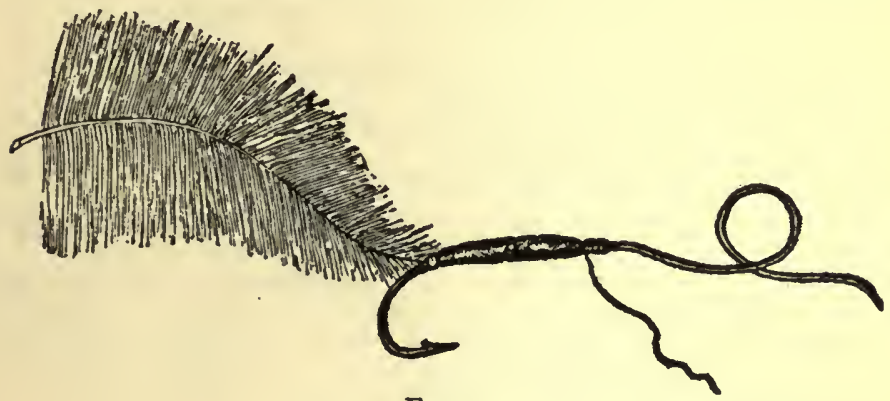

Fig. 7 .

the end of the shank to allow room for the head. At this stage your work should be like Figure 7 .

Now seize the hackle by the stem, and wind it spirally around the body, gradually working toward the head (see Figure 8), at each turn pressing back the fibres with your left thumb and finger to prevent them from being caught

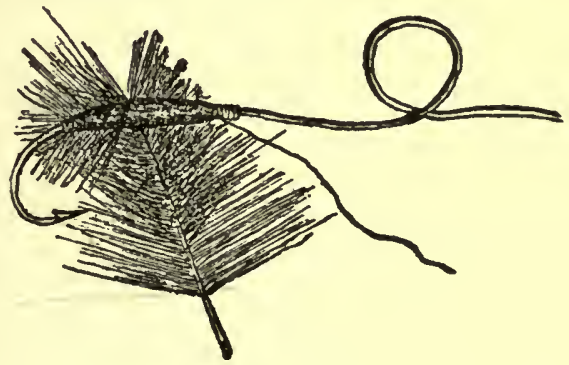

FIG. 8. under the next turn. You will find that in this process your hackle will go on much easier and 
with less chance of the fibres becoming wrapped under than it did in winding of the hackle at the shoulder only as on the previous hook. When you reach the end of the body, give two or three turns of the hackle at this point to allow a little fulness, then fasten the end with several turns of your binding silk, which must be wound

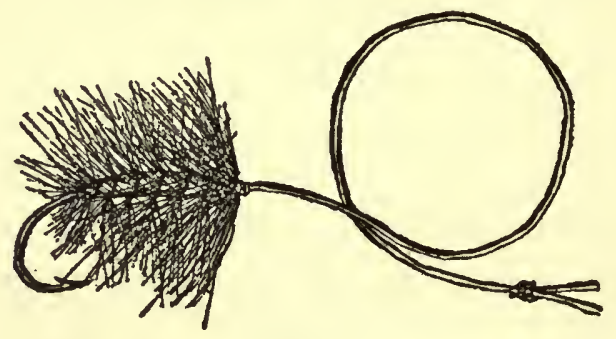

Frg. 9.

evenly and nice to form the head. Now compare your work with Figure 9.

In fastening the binding silk you may either use a half-hitch or two, or tie an invisible knot, which is much nicer. This is made as follows: Hold the binding silk with your right hand about an inch and a half or two inches from the end of the hook; hold it toward the right and with your left hand bring around the end over the head of the hook, thus forming a loop as in Figure ro. Now catch your thread with your right 


\section{How to Tie Artificial Flies $\quad 38 \mathbf{r}$}

hand at about the point marked $A$, and give it four turns around the head of the hook as shown
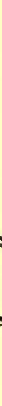

FIG. 10.

in Figure I I. Place your left thumb to hold it tight and poke the end of the snood through the
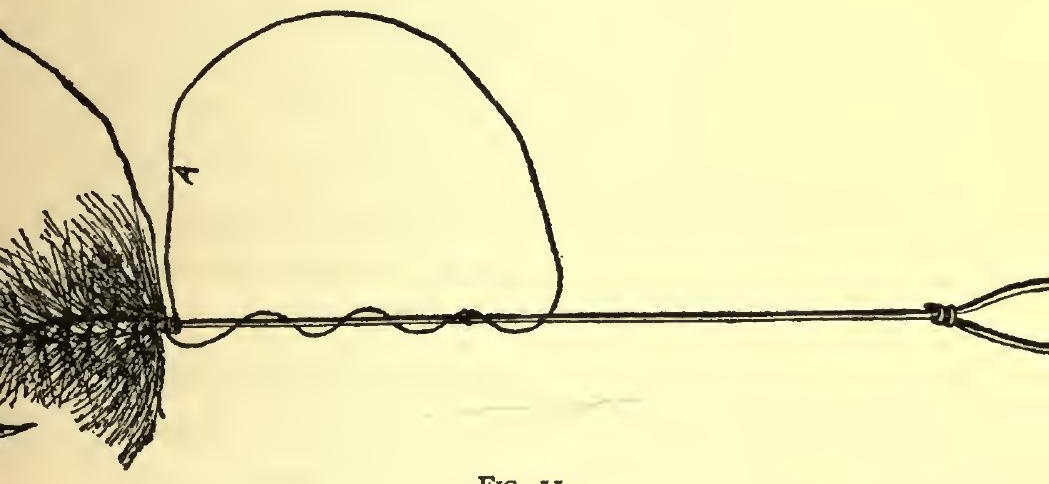

FIG. 11 .

loop four times to untwist it; then take the loose end and draw it tight. After this, cut off the 
loose end close up, and give it a coat of shellac, and your palmer fly is complete.

When you have learned to do what I have described up to this point, and practised enough to be able to do it well, you may call yourself a fly-tier, as the fancy flies are but slight variations from the standard ones. The very fancy and gaudy ones used for salmon and sea-trout are certainly very difficult to dress properly, but after you have had practice, it will come to you without much difficulty.

As a specimen of the variations we will next

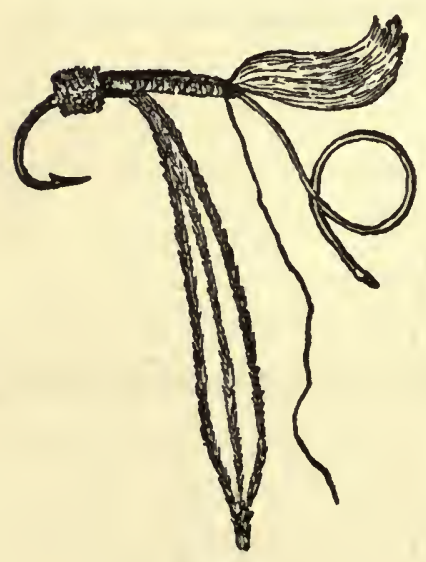

Fig. 12. take up the Royal Coachman. Wrap your snood as usual, and give a slight show of gold tinsel at the butt. Select three strands of peacock herl and fasten them the same as you did the hackle feather in tying a palmer; take the three together and wind them around the shank of the hook for a short distance, then catch the ends with two turns of the binding silk; with two turns 


\section{How to Tie Artificial Flies}

more catch in some bright red floss, and holding the loose strands of herl along the shank, wind the silk over both of them and the shank about three times; fasten the floss, cut off the end, and carry your binding silk up to the head, when your work should appear like Figure I 2. Now carry out the balance of the body with the peacock herl, put on the legs,

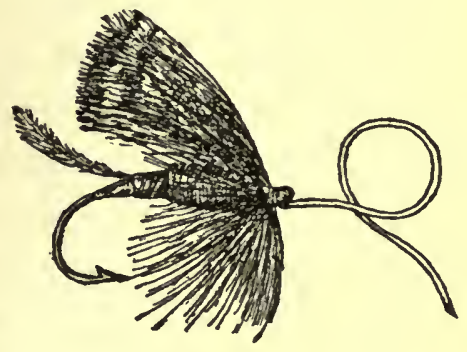

FIG. 13. and tie back your wings, and the fly is made, as shown in Figure $\mathrm{I} 3$.

Having described, in as simple a manner as possible, the method of dressing ordinary flies, I will now give a list of those flies in general use, making comments from time to time, when occasion requires, of any special style of dressing. I will not give an additional list of feathers and materials required, as all this knowledge may be gained from the descriptions of the flies.

Brown Palmer or Hackle. - Body, red silk floss ribbed with gold tinsel; legs, brown hackle wound whole length of body. This fly may be varied by using for the body yellow or green 
silk floss, peacock or ostrich herl. Where the herl is used there should be only a slight show of tinsel at butt. The fly may be further changed by adding to any of these variations a tail of either scarlet ibis or yellow feathers.

Gray Palmer. - This fly is dressed in the same manner and with all the variations as in the brown palmer, using gray hackle instead of brown.

Ginger Palmer. - Body, yellow silk floss ribbed with silver tinsel ; legs, pale ginger hackle wound whole length of body.

Grizzly Palmer. - Body, orange silk floss ribbed with gold tinsel; legs, white hackle wound whole length of body.

Coch-y-bon-dhu (Marlow Buzz). - Body, bright green peacock herl, with a slight show of gold at butt; legs, brown hackle wound at shoulder only.

Abbey. - Tail, two or three fibres of golden pheasant tippet feather; body, red wound with gold tinsel; legs, brown hackle; wings, gray widgeon.

Grizzly King. - Tail, red; body, green ribbed with gold tinsel; legs, furnace-gray hackle; wings, gray mallard.

Professor. - Tail, scarlet ibis; body, yellow silk floss ribbed with gold tinsel; legs, brown hackle; wings, gray mallard. 
Rube Wood. - Tail, brown mallard; tag, red silk floss with a turn of gold tinsel; body, white chenille; legs, brown hackle; wings, gray mallard.

Dusty Miller. - Tail, two or three fibres of gray mallard; body, dark gray mohair, ribbed with narrow gold tinsel (this ribbing is sometimes omitted); legs, gray hackle; wings, dirty gray turkey.

Light Montreal. - Tail, gray mallard; body, scarlet ribbed with gold tinsel; legs, scarlet hackle; wings, gray mallard.

Dark Montreal. - Tail, scarlet ibis ; body, crimson mohair, ribbed with gold tinsel; legs, crimson hackle; wings, wild turkey.

Queen of the Waters. - Body, orange silk floss ribbed with gold tinsel ; legs, brown hackle wound whole length of body; wings, gray mallard.

King of the Waters. - Same as Queen, except with red silk floss for body.

Cahill. - Tail, gray mallard; body, mouse-colored mohair, with slight show of gold at butt; legs, brown hackle; wings, side feather (not barred) from wood duck.

Green Drake. - Tail, lead color (blue heron); body, white ribbed with black silk; legs, brown 
hackle; wings, side feather (not barred) of wood duck dyed yellow.

Gray Drake. - Tail, gray mallard; body, white, ribbed with black silk; legs, gray hackle; wings, gray mallard.

March Brown. - Tail, Scotch grouse; body, dark brown, ribbed with yellow silk; legs, Scotch grouse; wings, Scotch grouse.

Shoemaker. - Tail, side feather (not barred) of wood duck; body, alternate bands of salmon and lead-colored silk, wound over with gut; legs, brown hackle; wings, gray mallard and wood duck (not barred).

Oak Fly. - Body, orange, ribbed with black silk; legs, brown hackle; wings, mottled brown turkey. (The wing coverts of the quail make a good wing for this fly.)

Grannom.- Tag, green silk floss with slight show of gold tinsel; body, gray mohair picked out at shoulder to represent legs; wing, pale gray turkey.

Seth Green. - Body, green silk floss, ribbed with yellow silk; legs, brown hackle; wings, light brown mottled turkey.

Brown Hen. - Tag, red silk floss; body, peacock herl; legs, brown hackle; wings, dark mottled brown turkey. 
Stone Fly or Caddis. - Tail, brown mallard; body, olive-colored mohair, picked out at shoulder to represent legs; wings, curlew or light feathers from wing of night heron.

Spider. - Body, lead-colored silk floss with slight show of gold tinsel at butt; legs, black hackle; wings, wild turkey.

Alder. - Body, peacock herl with slight show of gold tinsel at butt; legs, black hackle; wings, mottled brown turkey. With lead-colored wings, this fly is also called a gray alder.

Hare's Ear. - Body, mouse-colored mohair, picked out at shoulder to represent legs; wings, lead color.

Pale Blue Dun. - Tail, a few fibres of pale blue feather; body, mouse-colored mohair; legs, gray hackle; wings, pale lead color.

Iron Blue Dun. - Tail, English starling; body, blue-gray mohair, ribbed with yellow silk; legs, brown hackle; wings, starling.

Beaverkill. - Body, white silk floss, with slight show of gold tinsel at butt; legs, brown hackle wound whole length of body; wings, blue heron.

Red Fox. - Tail, two fibres of gray mallard; body, dirty red mohair; legs, brown hackle; wings, lead color. 
Cowdung. - Body, orange mohair, with slight show of gold tinsel at butt; legs, ginger hackle; wings, light curlew.

Coachman. - Body, peacock herl; legs, brown hackle ; wings, white.

Royal Coachman. Body, peacock herl, with a band of bright red silk floss around the middle; legs, brown hackle; wings, white.

Golden Spinner. - Tail, two fibres from ginger hackle; body, yellow silk floss, ribbed with gold tinsel; legs, brown hackle; wings, blue heron.

Red Spinner. - Tail, two fibres from brown hackle; body, red silk floss ribbed with gold; legs, brown hackle; wings, blue heron.

Jenny Spinner. - Tag, brown silk floss; tail, black fitch hair (two or three fibres from glossy black hackle will do in place of fitch hair); body divided into three parts, upper and lower parts brown silk floss and middle part white silk; legs, gray hackle; wings, pale lead color.

Blue Bottle. - Body, blue chenille ribbed with black silk; legs, black hackle, wings, dark lead color. Certain parties claim that the body of this fly should be made of a peculiar shade of steel-blue silk floss. It is impossible to describe this shade, 
and a specimen of the fly must be seen; ask your tackle dealer to show you one.

Bee. - Body, yellow chenille, with a band of black silk floss around centre; legs, brown hackle; wings, blue heron.

Dark Fox. - Tail, gray mallard; body, dark lead-colored mohair, picked out at shoulder to represent legs; wings, lead color.

Black Gnat. - Body, black ostrich herl; legs, black hackle; wings, dark lead color from the darkest feathers of the blue heron. This fly is often tied with black wings, but I think this is wrong. When it is tied on a No. Io or smaller hook, as is generally the case, the legs may be omitted. This fly is sometimes tied with an orange silk floss tag; it is then called McBride's black gnat.

Claret Gnat. - Body, claret-colored mohair, picked out at shoulder to represent legs (sometimes claret hackle is used for legs); wings, lead color.

Black Midge. - Body, black silk floss ribbed with fine silver tinsel; legs, black hackle; wings, dark lead color.

Light Claret. — Body, claret silk floss, with slight show of gold tinsel at butt; legs, claret hackle; wings, blue heron. 
Dark Claret. - Same as the light claret; except that black hackle is used for legs in place of claret.

Yellow Sallie. - Body, pale yellow silk floss ribbed with gold tinsel; legs, pale yellow hackle; wings, pale yellow.

Yellow May. - Tail, yellow; body, yellow silk floss, with slight show of gold tinsel at butt; legs, yellow hackle; wings, gray mallard dyed bright yellow.

Jenny Lind. - Tail, bright blue; body, deep yellow silk floss ribbed with gold tinsel; legs, claret hackle; wings, bright blue.

McBride's Professor. - Tail, scarlet ibis; body, yellow silk wound with gut and peacock sword at shoulder; legs, brown hackle; wings, mixed wood duck (not barred) and mallard all dyed yellow.

Black Ant. - Tag, black ostrich herl; body, black silk floss with black ostrich herl at shoulder; legs, black hackle; wings, grayish blue.

Scarlet Ibis. - Tail, scarlet ibis; body, red, ribbed with gold tinsel; legs, scarlet; wings, scarlet ibis.

Raven. - Body, dark green, ribbed with gold tinsel; legs, black hackle; wings, black.

White Miller. - Body, white silk floss, ribbed with silver tinsel ; legs, white hackle; wings, pure white. 
Blue Professor. - Tail, scarlet ibis; body, bright blue silk; legs, brown hackle; wings, lead color.

Cinnamon. - Tail, two fibres of cinnamon-colored feather; body, cinnamon silk floss ribbed with silver tinsel; legs, brown hackle; wings, cinnamon color. This fly is sometimes dressed with peacock-herl body, and is then called cinnamon with peacock body. A good cinnamoncolored feather is very difficult to obtain. The wings and tail of the Bird of Paradise are the only good colored ones the writer knows of. The name sounds expensive, but in reality these birds are cheap, as, after the said plumes have been pulled out for millinery purposes, the bodies become worthless, and may be purchased for a few cents.

Lowery. - Tag, yellow silk; body, peacock herl; legs, brown hackle; wings, cinnamon color.

Jungle Cock. - Tail, scarlet ibis; body, red, ribbed with gold tinsel; legs, claret hackle; wings, jungle cock rump hackle.

Epting. - Tail, two or three fibres of ginger hackle; body divided in three joints, lower joint, red silk floss, middle joint, orange silk floss, and upper joint, bright yellow silk floss, all ribbed with gold tinsel; legs, black hackle; wings, widgeon or teal. 
Adirondack. - Tag, yellow silk; tail, a few fibres of black hackle or black seal fur; body, reddish brown mohair; legs, orange hackle; wings, white, with jungle cock shoulders.

Nearly all the foregoing flies may be varied and made a little more elaborate by adding shoulders of jungle cock, as in the last two. Now we come to the fly that is tied any way and any how. No two dealers or professionals dress it alike. The Silver Doctor is used everywhere on all streams, and is, I might say, about the most popular fly in use.

For ordinary trout fishing the Silver Doctor is not dressed so elaborately as for bass or salmon. The one for trout is tied as follows:-

Tag, gold-colored silk floss ribbed with silver twist; tail, a few fibres of golden pheasant tippet; body, red, and ribbed quite closely with silver tinsel (the body is sometimes of silver tinsel, ribbed with red silk or wool); legs, blue hackle; wings, strips of blue, yellow, barred wood duck, dark turkey, bustard, scarlet ibis, and white; head, red wool. In tying this fly for large trout or bass add a few legs of guinea over the blue hackle.

Ashy. - Body, orange; legs, a peculiar ashy shade of hackle wound the whole length of body. 
Bob Barnwell's Ashy. - Body, yellowish green mohair ribbed with peacock herl and a strip of yellow mohair laid along each side; legs ashy hackle wound whole length of the body; head, red wool.

The amateur will have great trouble in procuring the peculiar shade of hackle for the two last flies. It would be well to buy an "ashy" from some reliable house, and keep it handy to match the feather at the first opportunity.

The Francis. - Tail, dark gray hackle; body, peacock herl ribbed with heavy cord of red silk floss; legs, dark gray hackle tied part way down the body; wings, two dark gray hackle feathers matched.

Magalloway. - Tail, short fibres of yellow and blue macaw; body, lower half brown mohair and upper half black ostrich herl ribbed with gold twist; legs, gray hackle; wings, brown feather from peacock primary; head, black ostrich herl. In using the brown primaries of the peacock, the amateur will have great trouble to get them to lie gracefully. A feather of the same shade is found in the two upright feathers of the wings of the mandarin duck. The fibres of the latter are not so harsh as the peacock, and are much easier to tie. 
Bemis Stream. - Tail, golden pheasant topping; body, brown mohair, ribbed with gold tinsel; legs, brown hackle; wings, strips of brown peacock and dark and light bustard; head, black ostrich herl.

Oquassac. - Tag, yellow silk floss; tail, sprigs of argus feathers and golden pheasant topping; body, claret mohair, ribbed with pink silk floss; legs, claret hackle; wings, argus feather (primary); head, black ostrich herl.

Tinselled Ibis. - Tail, a few fibres of barred wood duck and scarlet ibis; body, silver tinsel ribbed with gold twist; legs, scarlet hackle; wings, matched scarlet ibis feathers, with strips of barred wood duck on each side.

Chateaugay. - Tail, a few fibres of brown mallard; body, lemon-yellow silk floss ribbed with gold twist; legs, ginger hackle wound from tail to shoulder; wings, strips from widgeon and argus; head, black ostrich herl.

Mooselookmaguntic. - Tail, a few fibres of argus pheasant; body, equal parts of gray squirrel fur and light green mohair ribbed with gold twist; legs, brown hackle; wings, gray speckled turkey dyed yellow, with a strip of argus on each side; head, green ostrich herl. 
Rangeley. - Tail, a few fibres of barred wood duck and scarlet ibis; body, dark claret mohair ribbed with gold tinsel; legs, dark claret hackle; wings, strips of wood duck (barred) mixed with a little wild turkey and scarlet ibis.

Deacon. - Tail, gray mallard ; body, yellow mohair ribbed with silver and gold tinsel; legs, yellow hackle wound from tail to shoulder; wings, gray mallard; head, black ostrich.

Blue Jay. - Tail, scarlet ibis ; body, scarlet mohair ribbed with gold tinsel; legs, scarlet hackle; wings, matched feathers from English blue jays.

Dark Argus. - Tail, fibres of yellow, white, scarlet ibis, and wood duck; body, lower half red silk floss ribbed with silver tinsel, upper half bluish gray chenille; legs, crimson hackle, with blue hackle over; wings, matched feathers from back of red-breasted argus.

Black Prince. - Tail, scarlet ibis; body, silver tinsel; legs, black hackle; wings, black.

Parmachenee Belle. - Tail, scarlet ibis mixed with white; body, pale yellow mohair ribbed with gold; legs, scarlet and white hackle mixed; wings, mixed scarlet ibis and white. In putting on the legs of this fly, wind on the scarlet and white hackle together. 


\section{The Trouts of America}

Prouty. - Tag, orange silk floss ribbed with silver twist; tail, golden pheasant topping, with a few fibres of English blue jay; body, lower half silver twist, upper half black ostrich herl ribbed with silver twist; legs, yellow (dyed) furnace hackle wound over upper half of body; wings, mixed teal and yellow feather and a little scarlet ibis and red macaw; head, black ostrich herl.

June Spinner. - Body, black ostrich herl wound with silver tinsel; legs, black hackle; wings, black.

Cupsuptuc. - Tail, golden pheasant topping; body, silver tinsel wound with gold twist; legs, bright scarlet hackle wound from tail to shoulder; wings, mixed fibres of brown turkey tipped with white, brown mallard, golden pheasant tail, and guinea hen; head, black ostrich herl.

Doodle Bug or Kadoodle Bug. - Tag, green silk floss; tail, gray mallard dyed pale yellow; body, lower half pale yellow, upper half orange and ribbed with gold twist; legs, brown hackle wound full length of body; wings, brown turkey.

Conroy. - Tag, peacock herl from sword feather; body, crimson silk floss; legs, green hackle, with guinea hackle over; wings, matched feathers from the white-tipped tertials of mallard duck. 


\section{Artificial Flies}

Turkey.-Tail, scarlet ibis; body, yellow mohair ribbed with gold tinsel; legs, brown hackle; wings, brown turkey.

Saranac. - Tail, golden pheasant topping; body, claret silk floss ribbed with gold and silver twist; legs, claret hackle wound from tail to shoulder; wings, matched golden pheasant's tippets with strips of brown mallard and argus pheasant on each side.

Lightning Bug or Firefly. - Body, lower third, yellow silk floss, upper two thirds gray mohair, ribbed with gold tinsel; legs, gray hackle wound full length of body, with grouse hackle at shoulder; wings, brown turkey.

Wood Duck. - Tail, wood duck; body, bright yellow mohair ribbed with silver; legs, bright yellow hackle; wings, matched wood duck feathers.

Hopatcong. - Tail, scarlet ibis and yellow; body, silver tinsel; legs, black hackle wound full length of body; wings, brown turkey with jungle cock shoulders.

Ferguson. - Tail, scarlet ibis and yellow; body, yellow silk floss ribbed with gold tinsel; legs, green hackle; wings, brown turkey, scarlet ibis, yellow, and peacock swords. 
Round Lake. - Tail, fibres of golden pheasant tippet and two fibres of blue macaw; body, lower half orange, upper half claret mohair; legs, orange hackle; wings, brown turkey matched feathers with jungle cock shoulders.

Lord Baltimore. - Tail, black; body, orange silk floss ribbed with black silk; legs, black hackle; wings, black with jungle cock shoulders.

Whitney. - Tail, green; body, green silk floss ribbed with silver; legs, green hackle, wound from tail to shoulder (sometimes wound at shoulder only), under wing, yellow, over wing, night heron; head, peacock herl.

Governor Alvord. - Tail, scarlet ibis; body, peacock herl; legs, brown hackle; wings, blue heron with under wing of brown peacock.

Tuxedo. - Tag, red silk floss; tail, bright yellow; body, silver floss ribbed with gold twist; legs, orange hackle; wings, curlew, with narrow strip of bright yellow on each side.

Silver Miller. - Tail, scarlet ibis and yellow; body, silver tinsel ribbed with gold twist; legs, yellow hackle; wings, matched white feathers.

Pelee Island Ibis. - Tail, black; tag, black ostrich herl; body, red silk floss ribbed with gold; wings, matched scarlet ibis. 
Gogebic. - Tag, scarlet silk floss; tail, scarlet ibis and white; butt, black ostrich herl; body, yellow, ribbed with fine gold twist; legs, scarlet hackle wound from butt to shoulder; wings, white matched feathers with small ibis on each side.

White Moth. - Tail, scarlet ibis; body, white chenille; legs, white hackle; wings, matched white feathers.

I have now given a description of about all the standard flies used for trout. Of course there are many others, some used only in certain parts of the country, and others designed and used only by private parties and their friends.

Such knowledge as I possess of fly-tying was derived from the practical teachings of Samuel P. Kellogg of Elizabeth, New Jersey, who was undoubtedly one of the most skilled of amateur or professional fly-tiers, as he was certainly one of the best informed in the natural history of our feathered fauna. He is now deceased, and the cause of his death should be a warning to all who keep a stock of fly materials. He died from poison produced by the incautious use of arsenic. 


\section{INDEX}

Abbey fly, dressing, 384 .

Adirondack fly, dressing, 392.

Alaska salmon -

Annual yield of salmon, 175 .

Blueback salmon range, 161 .

Exhaustion and death of salmon in brooks, 169 .

Humpback salmon range, $16_{3}$, I69.

Quinnat range, $155,156$.

Silver salmon, 164 .

Alder fly, dressing, 387 .

Aleutian Islands salmon, 157 .

Alford, salmon fishing, 26, 121-122.

American braided line, inferiority of, 57 .

American split bamboo rod, salmon fishing, 78 .

Angling, antiquity and literature of, 4, 193-196.

[See also names of fish.]

Arctic trout [Salvelinus arcturus] $285,286,295,323$.

Armstead, J. J., trout fishing, beesting incident, 275 .

Artificial flies, tying and dressing, 368-399.

[See also title Flies, and names of fics.]

Ashy fly, dressing, 392.

Asia, trout origin, 198.

Atkins, Mr., salmon spawning experiments, $3 \mathbf{I}$.

Atlantic rivers, acclimatizing Pacific salmon, 173 .
Atlantic salmon -

Differences from Pacific species, I53-154.

Distinguishing small salmon from grilse, 12.

Extermination and decrease in various rivers, $37-46$; preventive methods, $40-41$.

Fishing, see Atlantic salmon fishing.

Food, 32, 35-36.

Fresh water, decrease of appetite in, 21-24, 27.

Fry, see that title.

Grilse, see that title.

History and habits, 3-36.

" Kippers," 124.

Migration, 27-29, 145.

Fresh water, habits as to ascent of rivers, 19-2I.

Return to native rivers, 29-3I. Numbers in proportion to grilse, 14-18.

Parr, see that title.

Pennell's "Proved Facts," 5-7.

Size, see subheading Weight and size.

Smolts, see that title.

Spawning, 27.

Extracts from Pennell, 5-7.

Penobscot salmon, 3I.

Vacillating characteristics, 3-4.

Weight and size, 32-35.

Diminution in size indicating deterioration of river, 46 . 
Atlantic salmon [continued] -

Weight and size [continued] -

Table estimating weight by length, 33-34.

Young, see Parr, Grilse, and Smolts.

Atlantic salmon fishing -

Bait, see that title.

Canadian rivers, see that title.

Casting the fly, see that title.

Fishing the pool, 99-113.

Flies, see that title.

Hours for, 4, r 30-r 34 .

Illegal fishing, enforcement of laws, 39-42.

Intuition of danger, 144-145.

Large salmon, encounters with, 1 22-127.

Logs, angling among, 145-147.

Mist on the water, 134 .

Netting, 28, 29.

Rising fish, 136-r43.

Season for angling in Canadian rivers, 145 .

Sleep of salmon, $135^{-1} 36$.

Sport of angling, 1 27-129, 148 .

Striking, playing, and landing, I I4-I 29.

Gaffing, 120.

Length of time required, anecdotes, 122-124.

Tackle, see names of tackle, Lines, Rods, etc.

Thunder-storms, I34.

Water, best stages for fishing, I44.

Wounded fish taking the fly, 23$24,142$.

[See also names of rivers.] Attacus cecropia, gut produced from, $6 \mathrm{r}$.

Baird, salmon hatching station, I 1 I.
Bait -

Atlantic salmon fishing, 4, 143.

Salmon rising to any object alleged, 24-26.

Varying bait to suit humor of fish, 4 .

Pacific salmon fishing, I80, I81, 182.

Steelhead angling, 188-189.

Trout, bait fishing, 331, 355, 360$362,366$.

"Baiting a buoy," method of lake trout angling, 292.

Battle Creek, salmon fishing, 184 .

Bean, Professor T. H., name for Sunapee trout, 324 .

Beardslee, Admiral L. A. - salmontrout species, 246.

Beaufort Moth fly, salmon fishing, 83,89 .

Beaverkill fly, dressing, 387 .

Bee, artificial, dressing, 389 .

Belle Isle, Strait of, salmon fishing in rivers north of, 52 .

Bemis Stream fly, dressing, 394 .

Bendire, Captain, discovery of Waha Lake trout, 228.

Berners, Juliana, Prioress of Sopwell, book on fishing, 194195.

Black Ant, dressing, 390.

Black bass -

Introduction into eastern waters, 251.

Intuition of danger, $3 \mathbf{r o .}$

Salt-ivater habitat, 284.

Black Gnat, dressing, 389 .

Black Midge fly, dressing, 389 .

Black Prince fly, dressing, 395 .

Black-spotted trout, see Cut-throat. Blueback salmon [Oncorhynchus nerka] $16 \mathrm{r}-\mathrm{r} 62$.

Characteristics, $16 \mathbf{r}$. 


\section{Index}

Blueback salmon [continued] -

Names of, 161 .

Size and weight, 162.

Value as food, canning, etc., I75. Blueback trout, see Oquassa trout. Blueback trout of Lake Crescent [Salmo gairdneri beards. leei] $21 \mathrm{I}$.

Characteristics, 246-248.

Blue Bottle, artificial, dressing, 388 . Blue Jay fiy, dressing, 395 .

Blue Professor fly, dressing, 390.

Bob Barnwell's Ashy fly, dressing, 393.

"Booke of St. Albans," first book on fishing, 194 .

Britannia fly, salmon fishing, 89 .

British Columbia, annual yield of salmon, 175.

Brook Pool, salmon fishing, Iog.

Brook trout of western Oregon

[Salmo irideus masoni] 211.

Characteristics, 255-256.

Brook or red-spotted trout [Salvelinus fontinalis] 286.

Angling, 306.

Antagonism to grayling, 216.

Colorado rivers, introduction of trout into, 227.

Coloration, 201-202, 303-305.

Preservation of color after capture, 305-306.

Description, 302-303.

Distinction from brown trout, $273,277$.

Favorite fish of anglers, 297-298. Food, 300-302.

Habits and range, 197, 298-300.

Hearing - concussion, 31 I-313.

Intuition of danger, 310.

Muscular powers, 298, 300.

Sight, 304, 307-310.
Brook trout [continued] -

Smell, 313-314.

Taste, 309, 313 .

Touch, 3 I4.

Brookes, R., treatise on angling, I 740, 4 .

Brown, N., salmon angling, 123.

Brown Fairy fly, salmon fishing, 85, 88.

Brown Hackle or Palmer fly, making, $378-382,383$.

Brown Hen fly, dressing, 386 .

Brown trout, see German or brown trout.

Bull trout, see Dolly Varden trout. Butcher fly, salmon fishing, 88,89 , 142.

Caddis fly, dressing, 387 .

Cahill fly, dressing, 385 .

California rivers -

Salmon culture, I 7 I.

Steelhead angling, 187 .

Canadian rivers -

Fresh salmon visitation in autumn, 9-10.

Salmon fishing, 42-52.

Season for angling, 145 .

[See also names of rivers.]

Carp imported from Germany, 25 I. Cascapedia River, salmon fishing, I 24.

Casting the fly -

Atlantic salmon fishing, 9I-98.

Bank, casting from, 93, 95 .

Boat, casting from, 92, 93, 95 .

Overhand casts, 91 .

Underhand casts, 96-97.

Wading, 95, 96.

Lines, see Casting lines.

Tournaments, $354,355,357$.

Trout fishing, 339 .

Grasshopper cast, 340-342. 
Casting the fly [continued] -

Trout fishing [continued] -

Learning to cast a fly, 354358.

Switch or Spey cast, 357 .

Casting lines or leaders -

Atlantic salmon fishing -

Care of line, 66.

Durability of line, $66-67$.

Length of gut, 61 .

Procuring gut, 60 .

Silk whipping, avoiding, 62 .

Tying - directions for making knots, 62-66, 72.

Trout leaders, selection of, 365 .

Causapscal fly, salmon fishing, 83 .

Chain of Rocks, salmon fishing, 25, 27, 143 .

Chaleurs Bay, rivers of -

Salmon migration, 20.

Salmon netting, 28.

Charr-trout -

Classification, 205, 285-286.

Distinguishing from brown trout, 273, 277 .

Dolly Varden, see that title.

European charr, see that title.

Great Lake trout, see that title.

Habits, 283.

Hearing - concussion, 31 I-313.

Identifying, 206-207, 273, 277, 285 .

Intuition of danger, 310.

Jordan River, variety found in, 196.

Markings, 284-285.

Migration, 283-284.

Sight, 306-310.

Sleep, $3 \mathbf{1} 4$.

Smell, 313-314.

Spawning habit of fontinalis, 296-297.

Species, 285-286, 294-296.
Charr-trout [continued] -

Species [continued] -

Cristivomer genus, $285,294$.

Imported species, 286.

Salvelinus genus, 286, 294296.

[See also names of species.]

Taste, 309, 313 .

"Tickling a trout," 314.

Touch, 314.

Chat eaugay fly, dressing, 394.

Chesapeake Bay pike, salt-water habitat, 284 .

China, quinnat range, 155 .

Chinook salmon -

Canning, 175 .

Trolling, 187 .

Cholmondeley Pennell, see Pennell. Cinnamon fly, dressing, 39r.

Clackamas River, salmon hatchery, 172.

Claret Gnat, dressing, 389.

Clarkii, cut-throat trout species, $210,220$.

Classification of fish -

Basis of, 265.

Coloration, 202-204, 324.

Habits of fish as factor, 326 .

Trout, see that title.

[See also names of various fish.] Coachman and Royal Coachman flies, dressing, $3^{82-383}, 3^{88}$.

Coast Range trout [Salmo irideus] 211.

Characteristics, 253-254.

Range, 255 .

Coch-y-bon-dhu fly, dressing, 384 .

"Cocking a fly," 348-349.

Colorado River trout [Salmo clarkii pleuriticus] $21 \mathrm{I}$.

Angling, 225, 228.

Description, 225.

Food, 228. 
Colorado River trout [continued] Similarity to Rio Grande trout, $223,225$.

Size and weight, 227.

Spawning, 228.

Colorado rivers, adaptability for fish life, 226-227.

Coloration of fish, difficulty of classi-

Columbia River fication, 200-204, 324 .

Centre of salmon fishery, 175 .

Quinnat range, $x_{55}, 1_{56}, x_{58}$.

Salmo clarkii gibbsii range, 222.

Silver salmon, 164 .

Steelhead classification, 241 .

Columbia River trout [Salmo clarkii] 210.

Description of, 214.

Range, 213.

Connecticut River salmon, illegal netting, 38 .

Conroy fly, dressing, 396.

Cotton, C., see Walton and Cotton.

Couch, J., salmon angling, 122.

Cowdung fly, dressing, 388 .

Cox, N., salmon fishing, bait, etc., 4 .

Crescent Lake, see Lake Crescent.

Cristivomer namaycush, Great Lake

trout, $285,286$.

Cristivomer namaycush siscowet, Siscowet trout, 285, 293.

Cunard, Sir B., salmon fishing on the Grimersta, 49.

Cupsuptuc fly, dressing, 396.

Cut-throat or black-spotted trout [Salmo clarkii] 210, 220.

Angling, 217-218.

Coloration, 200, 201.

Columbia River trout, see that title.

Differences from rainbow and steelhead, 201.
Cut-throat trout [continued] -

Food, 217.

Geysers, trout living in hot water, 219-220.

Habits, 215 .

Spawning, 218.

Varieties, 210-211.

[See also names of varieties.]

Dark Argus fly, dressing, 395 .

Dark Claret fly, dressing, 390.

Dark Fox fly, dressing, 389 .

Dark Montreal fly, dressing, 385 .

Dawson, king salmon fishing, 156 .

Deacon fly, dressing, 395 .

Dee, salmon fishing, 1 28, $135,136$.

Deveron River, salmon fishing, 30 , 3 I.

Dog salmon [Oncorhynchus keta] 165,169 .

Dolly Varden trout [Salvelinus parkei] 286, 295.

Characteristics, 317-319.

Distinguishing from Eastern trout, $318,320$.

Fishing, 319.

Names of, 286, 317, 3 18.

Native of Pacific slope, 198, 205.

Salt-water migration, 320 .

Doodle Bug, dressing, 396.

Dry and wet fly fishing, 349-350.

Dublin Pond trout [Salvelinus fon-

tinalis agassizii] 286, 295.

Characteristics, 316-317.

Dun Wing fly, salmon fishing, rog.

Durham Ranger fly, salmon fishing,

$85,88,89$, 104, I 10.

Dusty Miller fly -

Dressing, 385 .

Salmon fishing, rog, Iro.

Eastern charr [Salvelinus fontinalis] 320. 
Eastern charr [continued] Angling, 320.

Distinction from Dolly Varden, $318,320$.

Eastern continent, trout species, 198I99.

Eel river -

Salmon trolling, 183 .

Steelhead angling, 187, 189.

Elk Creek trout, 200, 202.

Elk River, cut-throat range, 213.

Epting fly, dressing, $39 \mathrm{I}$.

Esquimaux River, salmon fishing, 5 I. European charr or saibling [Salvelinus alpinus] 286.

Angling, 323.

Characteristics, 322-323.

Species, 322.

[See also names, Long-finned, Greenland, Arctic, and Sunapee.]

European sea-trout [Salmo trutta] 212.

Distinction from native sea-trout, $28 \mathrm{r}$.

Names, habits, etc., $281-282$.

Evermann, see Jordan and Evermann.

Fairfax, T., hours for angling, I 30.

Fairies, flies for salmon fishing, 85 , 88.

Feathers for fly-making, 370 .

Ferguson fly, dressing, 397 .

Firefly, dressing, 397.

Fishing, see names of fish.

Fishing the pool-salmon fishing, 99-113.

Flat Rock Pool, salmon fishing, 136. Flies -

Atlantic salmon fishing, 79-90. Anglers' theories, 79-80, 106. Attaching fly to leader, 6466,72 .
Flies [continued] -

Atlantic salmon fishing [cont.] Casting the fly, see that title.

Change of mind in salmon as to flies, 82, 106-I I 3 .

Color of flies, $85-88$.

Size of flies, $8 \mathrm{I}-85$.

Statement of flies used in fishing, I896, 109-1 10.

Varying conditions, use of different flies, 88 .

Below and above water, aspect of flies, 308.

Casting the fly, see that tille.

Macedonian " hippurus," I94.

Trout fishing, 330-332, 345353.

Brown trout fishing in Great Britain, 276-277.

"Cocking a fly," 348-349.

Colorado River trout, 228.

Cut-throat trout angling, $217-$ 218.

Dolly Varden trout, 319.

Dry and wet fly fishing, 349 .

Great Lake trout angling, 289.

Lake fishing, flies for, 353 .

List of flies in use, 383-399.

Night fishing, 350-352.

Norris, T., extract from writings, $347-348$.

Tying and dressing flies, 368399.

Types of flies to use, $346-347$, $352-353,366$.

Webber Lake trout, 236.

[See also names of fies.]

Floeberg charr [Salvolinus alpinus arcturus ] 285, 286, 323 .

Fontinalis, red-spotted charr-trout, 197.

[See Brook or red-spotted trout.] 
Forrest rod, salmon fishing, 77,78 .

Francis fly, dressing, 393.

Fraser River -

Blueback salmon range, 161 .

Centre of salmon fishery, 175 .

Fry, Atlantic salmon -

Extracts from Pennell, 5-6.

Habits and characteristics, 6.

[See also Parr, Smolts, and Grilse.]

Gaffing salmon, 120.

Gallatin River, trout coloration, 200.

Galway, salmon fishing, 128, 129 .

Gardner River, trout, 220.

Geneva Lake, Swiss lake trout, 286.

German or brown trout [Salmo fario] 212.

Angling in America and Great Britain, 274-278.

Bee sting incident, 275 .

Characteristics, 254, 271, 277.

Distinguishing from red-spotted charr, 273,277 .

Distribution, 272.

Food, destruction of other fish, 272.

Size, 251, 272, 274.

Spawning, 277-278.

Crossing experiments, 278 .

Geysers, trout living in hot water, 219-220.

Gilbert, Dr. -

Golden trout habitat, 270.

Steelhead forms, 241.

Steelheads and cut-throats, distinction between, 256 .

Ginger Palmer fly, dressing, 384 .

Godbout River, salmon fishing, 48 , 49,51 .

Gogebic fly, dressing, 399.

Golden Spinner fly, dressing, 388.

Golden trout of Mt. Whitney [Salmo irideus agua bonita] 212.
Golden trout of Mt. Whitney [cont.]-

Coloration, 266-268.

Confused with Sunapee trout, 267,324 .

Range, 270.

Season, route to Mt. Whitney waters, 270.

Golden trout of Sunapee Lake, see Sunapee trout.

Golet, see Dolly Varden trout.

Governor Alvord fy, dressing, 398.

Grand Cascapedia, salmon fishing, 46-47.

Grand Haven, Michigan, names for Great Lake trout, 287.

Grand Romaine, salmon fishing, 47.

Grannom fly, dressing, 386.

Grasshopper cast, trout fishing, 340342.

Gray Drake fly, dressing, $3^{86 .}$

Gray Palmer fly, dressing, 384 .

Grayling, relations to trout and whitefish, 216.

Great Britain, trout -

Brown trout angling, 275-278.

Dry and wet fly fishing, 349350.

Nomenclature of trout, $27 \mathrm{r}$.

Species of trout, 198.

Great Lake trout [Cristivonier namaycush] 285.

Angling, 289.

"Baiting a buoy" method, 292.

Flies, 289.

Trolling, 289, 291.

Characteristics, 288-289.

Markings, 285.

Names of, 208, 287-288.

Range, 205.

Siscowet trout, see that title.

Great Lakes, attempt to acclimatize salmon, 173 . 
Greenback trout [Salmo clarkii stomias] $2 \mathrm{rr}$.

Characteristics, 229.

Jordan's writings, 230.

Green Bay, Wisconsin, names for Great Lake trout, 287.

Green Drake fly, dressing, 385 .

Greenland charr [Salvelinus alpinus stagnalis] 286, 295, 323.

Grilse, Atlantic salmon -

Distinguishing from small salmon, 12.

Female development, 13 .

Migration, 18, 19.

Numbers in proportion to salmon, 14-18.

Restigouche River, see that title.

Return from salt water, 7 , ro, 1 r. Size and weight, $11,13,18,19,32$.

Spawning, extracts from Pennell, 5-7.

[See also Atlantic salmon.]

Grimersta River, salmon fishing, 49, 135,143 .

Grizzly King fly, dressing, 384 .

Grizzly Palmer fly, dressing, 384 .

Gulf coast, food of salmon, 36 .

Günther, variations in trout species, 199.

Gut, see Casting lines.

Hackle fly, $37^{8-382,} 383$.

Hackles for fly-making, 370 .

Hard-head trout, see Steelhead.

Hare's Ear fly, dressing, $3^{87}$.

Herodot us, ichthyic research, 193. "Hippurus," Macedonian fly, 194. Hooks -

Atlantic salmon fishing -

Attaching hook to leader, 6466,72 .

Pennell's writings, 70 .
Hooks [continued] -

Atlantic salmon fishing [cont.] Qualities necessary in perfect hook, 70.

Sizes of, diagram, 73.

Turn-down-eyed hook, 7 r.

Trout fishing, 367 .

Hopatcong fly, dressing, 397.

Hours for salmon fishing, 4, $130-134$.

Hudson River, salmon introduction and illegal fishing, 38-4I.

Humpback salmon [Oncorhynchus gorbuscha ] 162-164.

Characteristics, $162-163$.

Exhaustion and death in brooks of Alaska, $\mathbf{r} 69$.

Range, 163.

Spawning, 163 .

Huxley, Professor, salmon food, 32.

Ice fishing - trout fishing method, 330.

Idaho, Salmo clarkii gibbsii, 2 ro, 222.

Indians - salmon fishing, 9, 22.

Reef-net fishing, 176.

Silver salmon trolling, 185 .

Spearing, 176.

Inskeep, H., fly casting methods, 355 .

Iron Blue Dun fly, dressing, 387 .

Japan, silver salmon range, 164 .

Jenny Lind fly, dressing, 390.

Jenny Spinner fly, dressing, 388 .

Jock Scott fly, salmon fishing, 84,88 , 100, 102, 104, 105, 110.

Jointed rods, salmon fishing, 78 .

Jordan, Dr. -

Colorado rivers, adaptability for fish introduction, 226.

Greenback trout, 230.

Jordan River - charr-trout variety found in, $r 96$. 
Jordan and Evermann -

Brook trout of western Oregon, 256.

Trout species, 208.

Judge's Pool, angling among logs, 146-147.

June Spinner fly, dressing, 396.

Jungle Cock fly, dressing, 39r.

Kadiak, centre of salmon fishery, 175 .

Kadoodle Bug, dressing, 396.

Kamchatka, somka or mykiss trout, 212, 243.

Kamloops trout [Salmo gairdneri kamloops] 2I I.

Characteristics, 244-246.

Kellogg, S. P., fly-tying, 399 .

Kennebec River divested of fish by dam erection, 37 .

Kennedy, Mr., salmon fishing, Grand Cascapedia, 47.

Kern River country, description of, 262.

Kern River trout [Salmo irideus gilberti] 2 I I, 26x.

Characteristics, 263.

Golden trout, 268-270.

Species, 264.

Sporting qualities, 263-264.

King of the Waters fly, dressing, 385 .

King salmon, see Quinnat.

"Kippers," definition of, 124.

Kowak River, abundance of humpback and dog salmon, 163 .

Lac de Marbre trout [Salvelinus oquassa marstoni] 286, 295.

Characteristics and angling, 328, 329.

Lady of Merton fly, salmon fishing, I IO, I I I.
Lake Crescent -

Blueback trout, see that title.

Long-headed trout, 212, 239.

Speckled trout, 2 I I, 248.

Lake Geneva, Swiss lake trout, 286. Lake Oquassa, blueback trout migration, 327.

Lake Superior, steelheads, acclimatizing, I 73.

Lake Sutherland spotted trout [Salmo clarkii jordana] 2 II.

Characteristics, 239.

Lake Sutherland trout [Salmo clarkii declivifrons] $2 \mathbf{I}$.

Characteristics, 238.

Lake Tahoe, Truckee or "pogy" trout [Salmo clarkii henshawi] 210.

Characteristics, 234.

Method of fishing, 234 .

Range, 236.

Lake Tahoe, Truckee or silver trout [Salmo clarkii tahoensis] 210.

Markings, 232-233.

Method of fishing, 234 .

Range, 236.

Lake trout, see Great Lake trout.

Lakes, flies for trout fishing, 353 .

Leaders, see Casting lines.

Light Claret fly, dressing, 389 .

"Light Montreal " fly, making, 37 I378,385 .

Lightning Bug, dressing, 397.

Lines -

Atlantic salmon fishing -

American braided line, 57 .

Care of line, 58-60.

Casting lines, see that title.

Landing salmon, light and

heavy lines compared, II 8 . "Olinea," 58. 
Lines [continued] -

Atlantic salmon fishing [cont.]Selection, 58.

Tapered line, 58 .

Casting lines, see that title.

Trout fishing, 365 .

Lob worms - bait for Atlantic salmon, 4 .

Lock Leven trout [Salmolevenensis] 212.

Characteristics, 254, 279-28I.

Introduction and distribution, 279, 280.

Species, doubt as to, 279 .

Locke, J., salmon fishing, 26, 90.

Logs, angling among, 145-1 47 .

Long-finned charr [Salvelinus atpinus alipes] 286, 295, 323.

Long-headed trout of Lake Crescent

[Salmo bathocetor] 212, 239.

Lord Baltimore fly, dressing, 398.

Lower Snake River, steelhead classification, $24 \mathrm{I}$.

Lowery fly, dressing, 391.

Lucius reticulatus, Eastern pond pickerel, 284.

McBride's Black Gnat, dressing, 389.

McBride's Professor fly, dressing, 390. McCloud River trout [Salmo irideus shasta] 211.

Coloration and structure, 259$26 r$.

Introduction into Eastern and other states, 257-259.

Range of, 259, 261 .

Sporting qualities, $26 \mathrm{r}$. Macedonians, angling, 194, 196. Magalloway fly, dressing, 393. Malma trout, see Dolly Varden trout. March Brown fly, dressing, 386.
Marlow Buzz fly, dressing, $3^{84}$.

Maxwell, Sir H. -

Indifference of fish to color, 86.

Vertical position of sulking fish, I 26.

Mechanicsville dam, 39 .

Meek, Professor, trout of Lake Sutherland, 238.

Metapedia River, salmon fishing -

Dam construction, 30 .

Haul of salmon in I 886, 22.

Size of grilse, I3.

Mingan River, salmon fishing, 49.

Miramichi River, salmon migration, 20.

Mitchell, G. E., description of blueback trout, 247.

Moisie River, salmon fishing, 49.

Monterey Bay -

Quinnat range, 155 .

Salmon fishing, $179,183$.

Montreal flies, dressing, 385 .

Mooselookmaguntic fly, dressing, 394.

Mount Clairy, salmon fishing, 30 .

Mount Whitney trout, see Golden trout.

Mowat pool, salmon fishing, 107.

Mykiss trout, 21 2, 244.

Naresi trout [Salvelinus oquassa naresi] 286, 295.

Characteristics, 328.

Natashquan River, salmon fishing, 49.

Nepisiguit Gray fly, salmon fishing, 89, 108, I 10.

Nepisiguit River -

Grilse, weight of, 13 .

Salmon fishing, 115,136 .

"Nests," salmon, 159.

Nicholson fly, salmon fishing, 88,89 , IIO. 
Nissuee or no-shee trout [Salmo irideus stonei] 212.

Characteristics, 264.

Classification, 265.

Norris, T., trout fly fishing, 347-348.

No-shee trout, see Nissuee trout.

Norton sound, quinnat range, 155 , 156.

Norway, salmon fishing, 127, 128.

Nushagak River, quinnat range, I55.

Oak fly, dressing, $3^{86 .}$

Olemancheeboo River, salmon fishing, 50.

"Olinea" line, salmon fishing, $5^{8}$.

Ombre chevalier, 286, 322.

Oncorhynchus genus, Pacific salmon, 153.

[See Pacific salmon.]

Oncorhynchus gorbuscha, humpback salmon, I62.

[See Humpback salmon.]

Oncorhynchus keta, dog salmon, 165 , I69.

Oncorhynchus kisutch, silver salmon, 164.

Oncorhynchus nerka, blueback salmon, I6I.

[See Blueback salmon.]

Oncorhynchus tschawytscha, quinnat salmon, I54.

[See Quinnat salmon.]

Ontonagon River - coloration of trout, 202.

Oppian, treatise on fishing, 193.

Oquassa trout or blueback [Salvelinus oquassa] 286, 295.

Habits and characteristics, 326328.

Species, 286, 328.

[See also names, Naresi and Lac de Marbre.]
Oquassac fly, dressing, 394.

Oregon -

Brook trout of western Oregon, see that title.

Salmon culture, I71, I72.

Oregon charr, see Dolly Varden trout.

Orvis, C. F., gut strand in possession of, 61 .

Pacific salmon [Oncorhynchus] -

Acclimatizing, 172-1 74.

Blueback salmon, see that title.

Canning, 175 .

Cultivation, 1 70-1 72.

Differences from Atlantic species, I53-154.

Dog salmon, 165, 169.

Economic importance of, 175.

Feeding in fresh water, 167-170.

Fishing, see Pacific salmon fishing.

Humpback salmon, see that title.

Quinnat salmon, see that title.

Silver salmon, 164.

Spawning, exhausted condition of fish, 168-I 7o.

Steelhead, see that title.

Pacific salmon fishing, 177-187.

Annual yield, 175 .

Bait, 180, I81, 182.

Centres of salmon fishery, 175 .

Fly fishing, 178 .

Indian methods of taking salmon, 176.

Sea fishing, 179.

Spoon, 177-181.

Surface trawl, 184 .

Tackle, 180-181.

Trolling, 177-187.

Pale Blue Dun fly, dressing, 387 .

Palmer flies, making, $378-382,383$, 384.

Parmachenee Belle fly, dressing, 395. 
Parrs, Atlantic salmon -

Changing to smolt stage, 32.

Migration as smolts, see Smolts.

Spawning, 6.

Pelee Island Ibis fly, dressing, 398.

Pennell, Cholmondeley -

Hooks for salmon fishing, 70.

"Proved Facts in the History of Salmon," 5-7.

Weight of marked grilse, 32 . Penobscot salmon -

Decrease, 38 .

Spawning, 31.

Pickerel [Lucius reticulatus] salt water habitat, 284.

Pike of Chesapeake Bay, salt water habitat, 284.

"Pogy" trout, see Lake Tahoe trout. Popham fly, salmon fishing, 88.

Professor fly, dressing, 384 .

Prouty fly, dressing, 396.

Puget Sound -

Blueback salmon range, 161 .

Centre of salmon fishery, 175 .

Cut-throat trout range, 213.

Humpback salmon range, 163 .

Silver salmon, 164 .

Steelhead, markings, 242.

Trolling for salmon, 186.

Queen of the Waters fly, dressing, 385 . Quinnat salmon [Oncorhynchus Angling, 186. tschawytscha] 154-161.

Characteristics, 154-155, I57158.

Eggs, 160.

Migration, 157-158.

Names, 154, 156.

"Nests," 159.

Range of, 155 .

Sexual differences, 158 .

Size and weight, 156 .
Quinnat salmon [continued] -

Spawning, 158-160.

Transplanted to France, etc., 174.

Rainbow trout -

Coast Range trout, see that title.

Colorado, introduction of trout, 227.

Difference from cut-throat and steelhead, 201, 252-253.

Hardiness, 252.

Sporting qualities, 249-251.

Varieties, $211,249$.

[See also names of varieties.]

Rangeley fly, dressing, 395 .

Rangeley Lakes, habitat of Oquassa trout, 327 .

Rattlesnakes, Kern River Country, 262.

Raven fly, dressing, 390.

Red Fox fly, dressing, 387 .

Red Spinner fly, dressing, 388.

Red-spotted trout, see Brook trout.

Reef-net fishing, Indian method of taking salmon, 176 .

Reels -

Atlantic salmon fishing -

Improvement in manufacture of, 67 .

Multiplying and click reels, 68.

Width of, 68-69.

Trout fishing, 366 .

Restigouche River, salmon, 29, 124.

Grilse -

Female, lack of, 13-14.

Weight and size, I3.

Migration of smolts, 9, 11 .

Number and percentage of salmon and grilse taken by club, 1881-1900, 16-1 7.

Protection and lease of river, 43-44. 
Rio Grande trout [Salmo clarkii spilurus] $210,222$.

Abundance of, 222.

Characteristics, 223-224.

Similarity to Colorado River trout, 223, 225.

Rods -

Atlantic salmon fishing -

American split bamboo rod, 78.

Forrest rod, 77,78 .

Jointed and spliced rods, 78 .

Selection, 73-79.

Weight and length, 74-77.

Trout fishing, 366 .

Round Lake fly, dressing, 398.

Royal chinook salmon, name for quinnat, 156.

Royal Coachman fly, making, 382383,388 .

Rube Wood fly, dressing, $3^{85}$.

Sacramento River, Nissuee trout, 264.

Salmon fishing -

Indian methods, 176.

Quinnat range, $155,156$.

Surface trawl, 184.

Saibling, see European charr.

St. Anne de Monts River, salmon fishing, 48 .

St. Croix River, salmon decrease, $3^{8}$.

St. John River, salmon fishing, 50, 51 .

St. Lawrence River, salmon fishing, $42,173$.

Salmo, trout, 206.

[See Trout.]

Salmo bathacetor, long-headed trout, 212, 239.

Salmo clarkii, cut-throat trout, 200, 210. [See Cut-throat trout.]

Salmo clarkii bouvieri, Waha Lake trout, 21 I, 228.
Salmo clarkii declivifrons, Lake Sutherland trout, 21 1, 238. Salmo clarkii gibbsii, 210, 222.

Range, 222.

Salmo clarkii henshawi, Lake Tahoe trout, 2 IO, 234.

Salmo clarkii jordana, spotted Lake Sutherland trout, 211, 239.

Salmo clarkii lewisi, Yellowstone trout, 2IO, 221.

Salmo clarkii macdonaldi, yellowfin trout, 2I I, 230.

Salmo clarkii pleuriticus, Colorado River trout, 21 1, 226.

Salmo clarkii spilurus, Rio Grande trout, 210, 222.

Salmo clarkii stomias, greenback trout, 21 I, 229.

Salmo clarkii tahoensis, silver trout of Lake Tahoe, $210,232$.

Salmo clarkii virginalis, trout of Lake Utah, $210,237$.

Salmo fario, brown or German trout, $212,271$.

Salmo gairdneri, typical steelhead, I65, 21 I, 240.

Salmo gairdneri beardsleci, blueback trout, 2 I I, 246.

Salmo gairdneri crescentis, speckled trout of Lake Crescent, $211,248$.

Salmo gairdneri kamloops, kamloops trout, 21 I, 244.

Salmo irideus, rainbow trout, 21 I253.

Salmo iridens agua bonita, golden trout, 212, 266.

Salmo irideus gilberti, Kern River trout, $21 \mathrm{I}, 26 \mathrm{I}$.

Salmo irideus masoni, brook trout, 2 II, 255.

Salmo irideus shasta, McCloud River trout, $211,256$. 
Salmo irideus stonei, Nissuee trout, 212, 264.

Salmo levenensis, Lock Leven trout, 21 2, 279.

Salmo mykiss, cut-throat trout, 212. Salmo salar, Atlantic salmon, 3, 153-154.

[See Atlantic Salmon.]

Salmo trutta, sea-trout of Europe and Asia, 209, 212, 281.

Salmon, see Atlantic salmon, and Pacific salmon.

Salmon fishing -

Atlantic salmon fishing, see that title.

Canada and Norway compared with Scotland, 1 27-129.

Pacific salmon fishing, see that title.

Tackle, see Rods, Lines, etc.

United Kingdom, value of fish. eries, 42.

Salmon-trout -

Black-spotted, see Cut-throat.

Classification, 205, 210, 266.

Cut-throat, see that title.

Foreign species, 21 2, 271-282.

[Seealso German, Loch Leven, and European sea-trout.]

Identifying, 206-207.

Rainbow trout, see that title.

Steelhead, see that title.

Technical and popular names, 210-2I 2.

Use of phrase "salmon trout," 208. Salvelinus, charr-trout, 205.

[See charr-trout.]

Salvelinus alpinus, European charr, 286, 322.

Salvelinus alpinus alipes, longfinned charr, 286, 295, 323. Salvelinus alpinus arcturus, Arctic trout, $285,286,295,323$.
Salvelinus alpinus aureolus, Sunapee trout, 286, 324.

Salvelinus alpinus stagnalis, Greenland charr, 286, 295, 323 . Salvelinus fontinalis, brook trout, 286, 297.

[See Brook trout.]

Salvelinus fontinalis agassizii, Dublin Pond trout, 286, 316.

Salvelinus lemanus, Swiss Lake trout, 286.

Salvelinus oquassa, Oquassa trout, $286,326$.

Salvelinus oquassa marstoni, Lac de Marbre trout, 286, 323.

Salvelinus oquassa naresi, Naresi trout, $286,328$.

Salvelinus parkei, Dolly Varden trout, 286, 317 .

Saranac fly, dressing, 397 .

Scandinavian Peninsula, species of salmonoids, 199.

Scarlet Ibis, dressing, 390.

Schuylkill River, hearing and smelling senses of fish, 312 , 3I 3-314.

Sea-trout, see European sea-trout.

Seals living without food, 168-169.

Seth Green fly, dressing, 386.

Shasta rainbow, see McCloud River trout.

Shoemaker fly, dressing, 386 .

Sierra Nevada waters, McCloud River trout range, 261.

Silkworm, procuring gut from, 60 . Silver Doctor fly -

Making, 392.

Salmon fishing, 85,88 , 100, 104, I06, 107, I10, 142 .

Silver Miller fly, dressing, 398.

Silver salmon [Oncorhynchus kisutch] 164 .

Trolling for, 185 . 
Silver trout, see Lake Tahoe trout. Siscowet trout [Cristivomer namay. cush siscowet] 285.

Deep-water haunts, 293-294.

Sleep of fish -

Atlantic salmon, $135^{-136 .}$

Charr-trout, 314.

Smolts, Atlantic salmon -

Changing from parr stage, 32.

Extracts from Pennell, 6-7.

Growth, rapidity of, 10.

Migration to salt water and return, 6-11, 18, 19 .

Return from salt water as grilse, see Grilse.

Snakes, Kern River country, 262.

Somka trout of Kamchatka, $212,243$.

Sopwell, Prioress of, book on fishing, 194-195.

South Platte River, greenback trout, 229.

Spawning, see names of fish.

Spearing salmon, Indian method, 176. "Speckled fishes," Macedonian angling, 194, 196.

Speckled trout of Lake Crescent

[Salmogairdnericrescentis] 21 I, 248.

Spey, salmon fishing, 128.

Spey cast, 96-97, 357 .

Spider fly, dressing, $3^{87}$.

Spliced rods, salmon fishing, 78 .

Spokane River, cut-throat trout fish-

Spoon ing, $214,215$.

Atlantic salmon taken at Chain of Rocks, 143.

Pacific salmon fishing, 177-181.

Steelhead fishing, 188, 189 .

"Sporting Fish of Great Britain," extracts, 5-7.

Spotted trout, see Lake Sutherland spotted trout.
Stanley, H. O., hardiness of blueback trout, 327 .

Steelhead, hardhead trout [Salmo gairdneri] $211,240$.

Characteristics, 165-167, 241242.

Classification, 21 1, 24 I.

Belonging to trout species, $165,190$.

Differences from cut-throat and rainbow species, 201, 24I, 252-253.

Fishing, 187-190.

Great Lakes, acclimatizing salmon, 173 .

Names, 243-244.

Range, 242.

Sporting qualities, 243.

Value as food, 175-176.

Varieties, $211,240$.

[See also names of varieties.]

Stit-tse trout [Salmogairdneri kamloops] 211.

Stone, L., salmon hatching, 1873 , I 7 . Stone fly, dressing, 386.

Stormontfield on the Tay -

Grilse, weight of, 32.

Smolt migration, 8. Striking salmon, I14-1 20.

Sturdy, E., table estimating weight of salmon by length, 3334.

Sucker River, salmon fishing, 174 . Sunapee trout [Salvelinus alpinus

Angling, 323. aureolus ] 286, 295.

Characteristics, 325 .

Coloration, 325 .

Confused with Mount Whitney golden trout, 267,324 .

Range, 325 .

Sutherland, Lake, see Lake Sutherland. 
Swiss lake trout of Lake Geneva [Salvelinuslemanus] 286. Switch or Spey cast, 357 .

\section{Tackle -}

Atlantic salmon fishing, 53-90.

Examination of tackle, 53-54, 73, 121.

Pacific salmon fishing, 180-181.

Trout fishing, see that title.

[See also Lines, Rods, etc.]

Tahoe, see Lake Tahoe.

Teeth, distinction between salmontrout and charr-trout, 206.

Thunder Bay, name for Great Lake trout, 287.

Thunder-storms -

Atlantic salmon fishing, 134 .

Trout fishing, 334.

"Tickling a trout," 3 I4.

Tideway River, salmon fishing deterioration, 44 .

Tinselled Ibis fly, dressing, 394.

"Tippets," attaching fly to, 64, 72.

Togue, see Great Lake trout.

Tools for fly-tying, 369 .

Traherne, Major -

Flies, changing, 88.

Hours for angling, I33.

Rods for salmon fishing, 76-77.

Undercasts on the Spey, 96.

Traverse Bay, Michigan, names for Great Lake trout, 287.

Trawl, surface, salmon fishing, 184.

Trolling -

Salmon, $177-187$.

Trout fishing, 330.

Great Lake trout, 289, 291.

Trout [Salmo $]$ -

Charr-trout, see that title.
Trout [continued] -

Classification of species, 189-209.

Based on anatomical differences, 204-208.

Teeth and scales, 207, 208.

Coloration, 200-204.

Effect of properties of water, 202.

Differences in size and proportions, 204.

[See Charr-trout and Salmontrout.]

Distribution, 196-198.

Fishing, see Trout fishing.

Great Britain, see that title.

Native and foreign species in

American waters, 197, 198, 205, 206.

Salmon-trout, see that title.

Salt-water migrators, 320-321.

Steelhead, see that title.

Use of terms "trout" and "salmon trout," 205-206, 208.

[See also names of species.]

Trout fishing -

Atmospheric conditions, 333-337.

Bait fishing, 331, 355, 360-362, 366.

Casting the fly, see that title.

Fishing a trout stream, 337-345.

Flies, see that title.

Fly-fishing methods, 330-332.

Hooked trout -

Handling, 358-360.

Resistance of fish, entanglement of line, 344 .

Strain exerted, table, 57.

Methods, 330-331.

Pools, fishing, 344-345.

Rise of water, trout habits, 336337.

Rising trout habits, 343 . 
Trout fishing [continued] -

Tackle, selection of, 362-367.

First outfit, 363 .

Flies, see that title.

Hooks, 367 .

Leaders, 365 .

Line, 365 .

Reel, 363-365.

Rod, 362.

Up-stream and down-stream, $332-333$.

Troy dam, 39 .

Truckee trout, see Lake Tahoe trout.

Turkey fly, dressing, 397.

Tuxedo fly, dressing, 398.

Tweed River, numbers of grilse and salmon, $15-16$.

Twin Lakes, Colorado, yellow-fin trout, $23 x$.

Upper Arkansas river, greenback trout, 229.

Usk Grub fly, salmon fishing, 83 .

Utah lake trout [Salmo clarkii virginalis] 210.

Characteristics, 237.

Vicaire, J., flies for salmon fishing, $80-81$.

Waha Lake trout [Salmo clarkii bouvieri] 211 .

Characteristics, 228-229.

Discovery of, 228.

Walton and Cotton -

Brown trout, 27I, 277.

Hooking fish, 360 .

Washington state, salmon culture, I 7 I.

Webber Lake, trout fishing, 235236.
Wells, H. P. -

Salmon fishing tackle -

Gut, obtaining, 60.

Hooks, 7o.

Trout fishing, strain exerted by trout, 56-57.

Wet and dry fly fishing, 349-350.

White Miller fly, dressing, 390 .

White Moth, dressing, 399.

Whitney fly, dressing, 398.

Williamson, A. -

Sleep of salmon, 135 .

Sport in Canada and Scotland, 127.

Wilmot, S., sleep of salmon, 135 .

"Wilson" spoon for salmon fishing, 181.

Wood Duck fly, dressing, 397.

Wood River -

Salmo clarkii gibbsii, 222.

Trout classification, 201.

Worde, W. de, first book on fishing published by, 194 .

Yellow-fin trout [Salmo clarkii macdonaldi] $2 \mathrm{II}$.

Characteristics, 230-232.

Yellow May fly, dressing, 390.

Yellow Sallie fly, dressing, 390.

Yellowstone Park, geysers, trout fishing, 219 .

Yellowstone River, trout fishing and coloration, 200, 221.

Yellowstone trout [Salmo clarkii lewisi] $210,22 \mathrm{r}$.

Yukon River, quinnat range, 155 , I 56.

"Zebra trout" - brown trout crossing experiments, 278 . 



\section{AMERICAN SPORTSMAN'S LIBRARY}

\section{Edited by CASPAR WHITNEY}

To be completed in ten volumes, with numerous lllustrations

Each of these volumes will be prepared by a writer, or group of writers, thoroughly in sympathy with the work, and fitted for his special subject. The series will be under the editorial supervision of MR. CASPAR WHITNEY, the editor of Outing, and for many years sporting editor of Harper's Weekly.

THE DEER FAMILY. By Hon. Theodore Roosevelt, T. S. Van Dyke, and H. G. Stone. Illustrated by CARL Rungius. Now ready. Price $\$ 2.00$, net.

UPLAND GAME BIRDS. By Edwyn Sandys. Illustrated by Louis Agassiz Fuertes, A. B. Frost, and J. O. Nugent. Now ready. Price $\$ 2.00$, net.

SALMON AND TROUT. By Dean Sage and William C. Harris. Illustrated by A. B. Frost and others. Now ready. Price $\$ 2.00$, net.

Further volumes will include articles on the Bear Family, Water Fowl, Wild Fowl, Taxidermy, etc., Cougar, Wild Cat, Wolf, Fox, etc., Tuna, Tarpon, etc., Bass, Perch, Pickerel, etc.

\section{THE MACMILLAN COMPANY}





$1962^{21}$

\section{University of California}

SOUTHERN REGIONAL LIBRARY FACILITY

405 Hilgard Avenue, Los Angeles, CA 90024-1388

Return thls materlal to the llbrary

from which it was borrowed.

\section{ÁP保 2006 .}




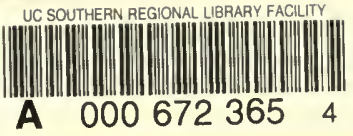



f

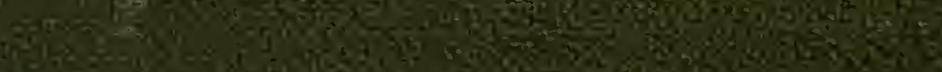

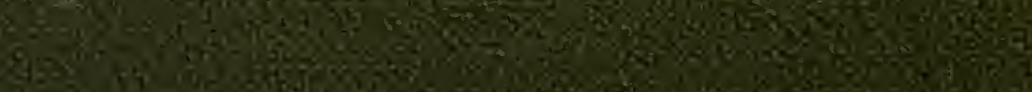
Dow

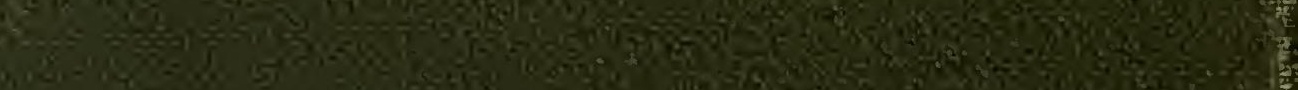
5. 20.

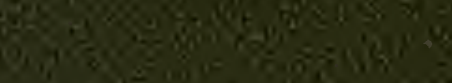

$$
\begin{aligned}
& \left.\sin _{0} x^{4}\right)
\end{aligned}
$$

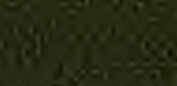

$\sin$ 